\title{
Direct triple annulations: a way to design large triazastarphenes with intertwined hexagonal packing
}

Qian Li, ${ }^{\mathrm{a}}$ Chady Moussallem, ${ }^{\mathrm{a}, \mathrm{c}}$ Frédéric Castet, ${ }^{\mathrm{a}}$ Luca Muccioli, ${ }^{\mathrm{b}}$ Marie-Anne Dourges, ${ }^{\mathrm{a}}$ Thierry

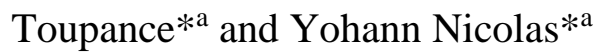

a'Univ. Bordeaux, CNRS, Bordeaux INP, ISM, UMR 5255, 351 Cours de la Libération, F-33405 Talence, Cédex. ${ }^{\text {b}}$ Department of Industrial Chemistry "Toso Montanari", University of Bologna, Viale Risorgimento 4, 40136 Bologna, Italy.

'Université Libanaise, Faculté des Sciences, Laboratoire de Chimie, Campus Michael Slayman, 1352 Rasmaska, Lebanon

* Corresponding author at : Institut des Sciences Moléculaires, Univ. Bordeaux, UMR 5255 CNRS, 351 Cours de la Libération, F33405 Talence Cedex, France.

E-mail address: yohann.nicolas@enscbp.fr; thierry.toupance@u-bordeaux.fr 


\section{Contents}

Direct triple annulations: a way to design large triazastarphenes with intertwined hexagonal packing

A. Materials, Methods and synthesis

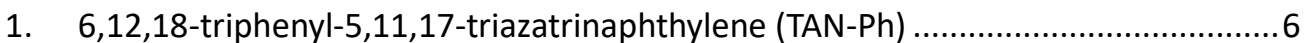

2. 6,12,18-tri-p-tolyl-5,11,17-triazatrinaphthylene (TAN-MePh) ..............................

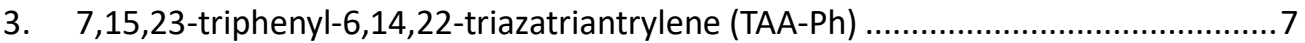

4. 7,15,23-tri(triisopropylsilylethynyl)-6,14,22-triazatriantrylene (TAA-Tips) ...............7

5. 7,15,23-tri(3,4,5-trimethoxyphenyl)-6,14,22-triazatriantrylene (TAA-OMePh) ........8

6. 7,15,23-tri(3,5-di-tert-butylphenyl)-6,14,22-triazatriantrylene (TAA-tBuPh)............8

7. 7,15,23-tri(3,5-di-trifluoromethylphenyl)-6,14,22-triazatriantrylene ( $\left.\mathrm{TAA}^{-} \mathrm{CF}_{3} \mathrm{Ph}\right) \ldots 9$

8. 2-amino-N-methoxy-N-methyl-3-naphthamide ....................................................

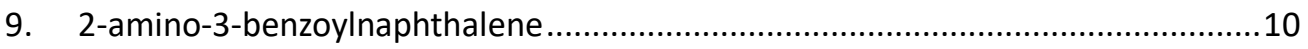

10. 1-(3-(2-aminonaphthalenyl)-3-(triisopropylsilyl)-2-propyn-1-one ..........................10

11. 2-amino-3-(3,4,5-trimethoxy)benzoyInaphthalene .............................................11

12. 2-amino-3-(3,5-di-tert-butyl)benzoylnaphthalene.............................................11

13. 2-amino-3-(3,5-bis(trifluoromethyl))benzoylnaphthalene .....................................12

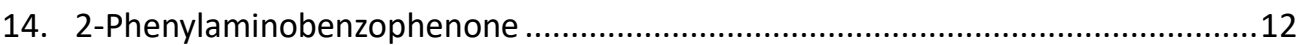

15. $[1,4-$ Phenylenebis(imino-2,1-phenylene)]bis(phenylmethanone) ..........................13

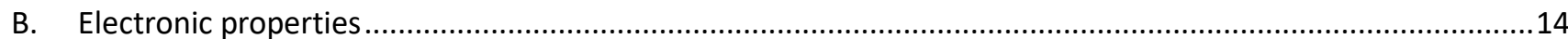

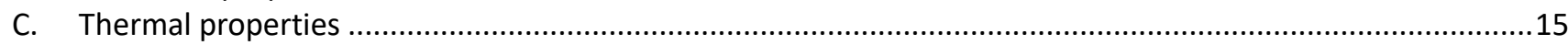

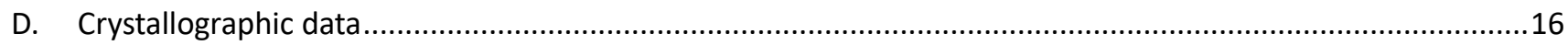

1. Geometrical parameters for each individual molecules .......................................18

2. Molecules and their closer neighbors in packing................................................19

3. Thermal ellipsoid plot .....................................................................................22

4. Representation of packing with whole molecular structure .................................28

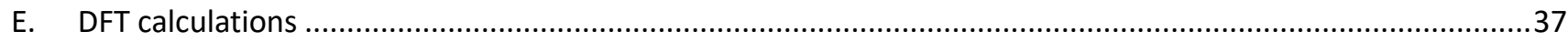

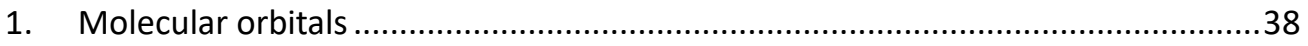

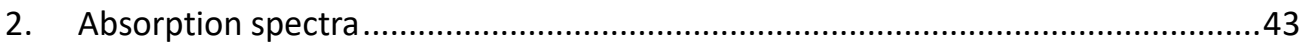

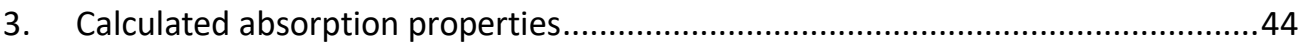

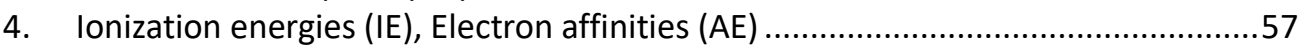

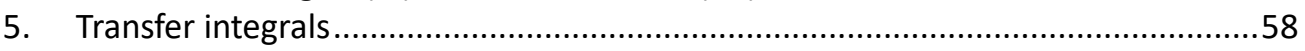

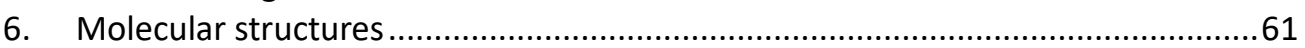

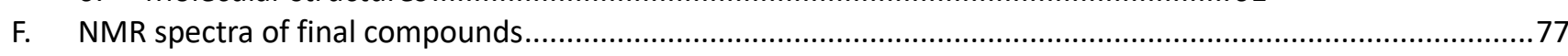

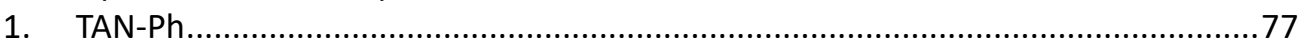

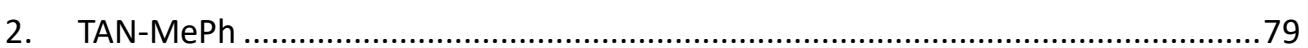

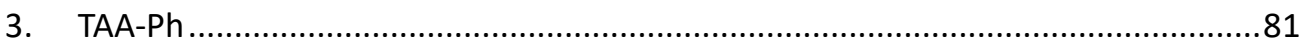

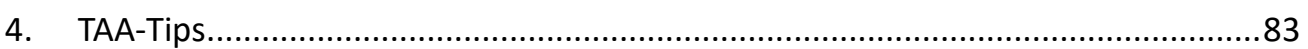

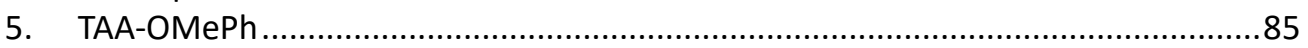

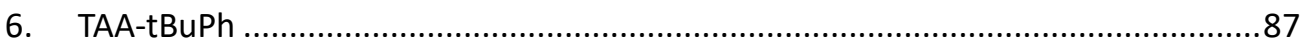

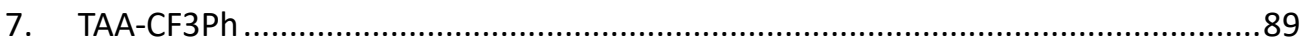

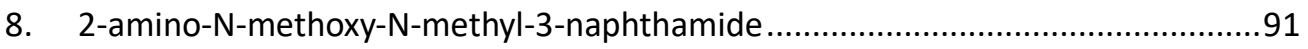

9. 2-amino-3-benzoylnaphthalene .....................................................................92

10. 1-(3-(2-aminonaphthalenyl)-3-(triisopropylsilyl)-2-propyn-1-one .........................93

11. 2-amino-3-(3,4,5-trimethoxy)benzoylnaphthalene .............................................94

12. 2-amino-3-(3,5-di-tert-butyl)benzoylnaphthalene..............................................95

13. 2-amino-3-(3,5-bis(trifluoromethyl))benzoyInaphthalene....................................96

14. 2-Phenylaminobenzophenone ........................................................................98

15. [1,4-Phenylenebis(imino-2,1-phenylene)]bis(phenylmethanone) .......................100

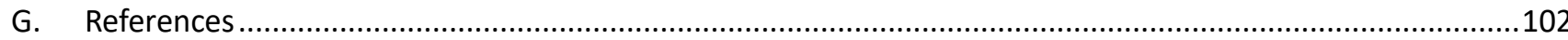




\section{A. Materials, Methods and synthesis}

All the chemical reagents were purchased and used as received (3-amino-2-naphthoic acid provided by fluorochem; BrettPhos, 5-bromo-1,2,3-trimethoxybenzene and 1-bromo-3,5-di-tert-butylbenzene by Sigma-aldrich; diphenyl chlorophosphate and triisopropylsilylacetylene by TCI; 1-bromo-3,5-bis(trifluoromethyl)benzene and 2aminobenzophenone by Alfa Aesar. Solvents used below were dried and freshly distilled before use. For TAN derivatives, 2-amino-4'-methylbenzophenone was obtained by the reported method ${ }^{1}$.

Structural assignments were made with additional information from gCOSY, gHSQC, and gHMBC experiments.

Mass spectra were performed by the CESAMO (Bordeaux, France) on a Qexactive mass spectrometer (ion trap, Thermo) or on a QStar Elite mass spectrometer (TOF, Applied Biosystems). The instruments are equipped with an ESI source and spectra were recorded in the positive mode. The spray voltage was maintained at a value between $3200 \mathrm{~V}$ and $4500 \mathrm{~V}$. The capillary temperature was set between room temperature and $320^{\circ} \mathrm{C}$. Samples were introduced by injection through a 20 $\mu \mathrm{L}$ sample loop into a flow (from 300 to $400 \mu \mathrm{L} / \mathrm{min}$ ) of methanol from the $\mathrm{LC}$ pump.Melting points were recorded by differential scanning calorimetry and confirmed by a melting point apparatus (MP90 Mettler Toledo).

Triazatrinaphthylene (TAN) derivatives TAN-Ph and TAN-MePh were synthesized following the route shown in Scheme S-A.1. Triazatrianthrylene (TAA) derivatives TAA-Ph, TAA-Tips, TAA-OMePh, TAA-tBuPh and TAA-CF3Ph were synthesized following the route shown in Scheme S-A.2.

For TAA derivatives, 3-amino-2-naphthoic acid was modified into its Weinreb amide counterpart before reacting with Grignard reagent and organolithium compounds to get ketone derivatives. The final products were synthesized by one-pot reactions between amino-ketones and 1,3,5-tribromobenzene with quite high yield (about 75\%).

Scheme S-A.3 describes reaction carried out with mono and dibromobenzene which stopped after the coupling reaction. Reactions with sterically hindered reactants described in Scheme S-A.4 failed to led to triazatrinaphthylene (TAN) or triazatrianthrylene (TAA) derivatives.

Scheme S-A.5 describes the steps and intermediates in the last reaction. The first intermediate is likely obtained in the reaction mixture. Then, the order in which the other steps are performed are speculative.

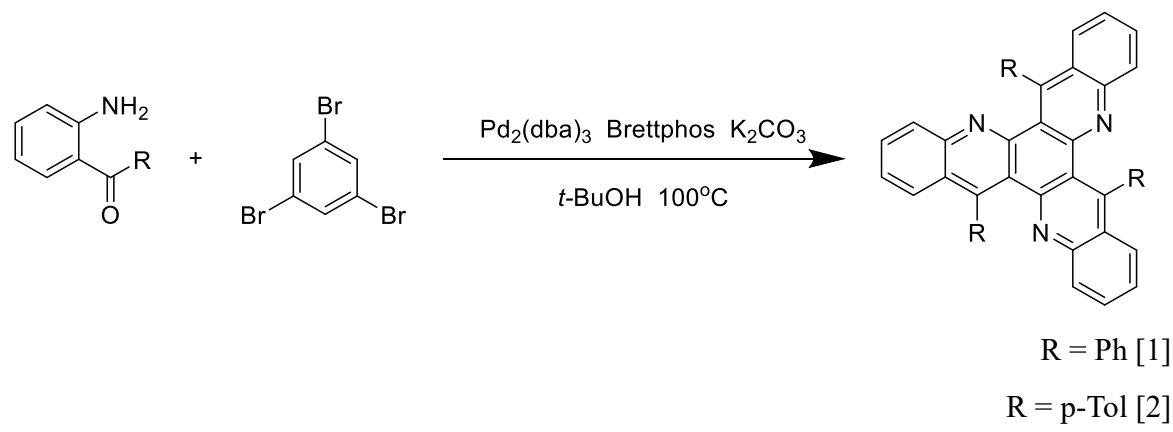

Scheme S-A.1. Synthetic route of TAN derivatives.

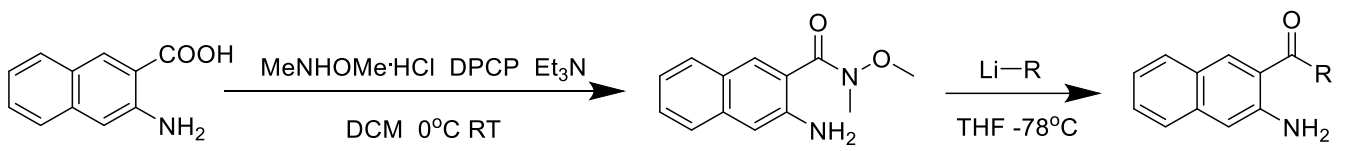

[8]

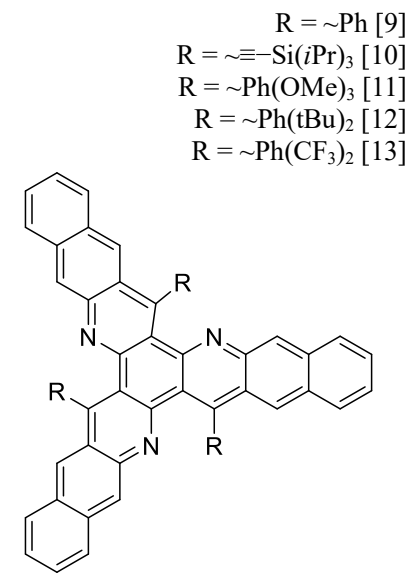


Scheme S-A.2. Synthetic route of TAA derivatives.
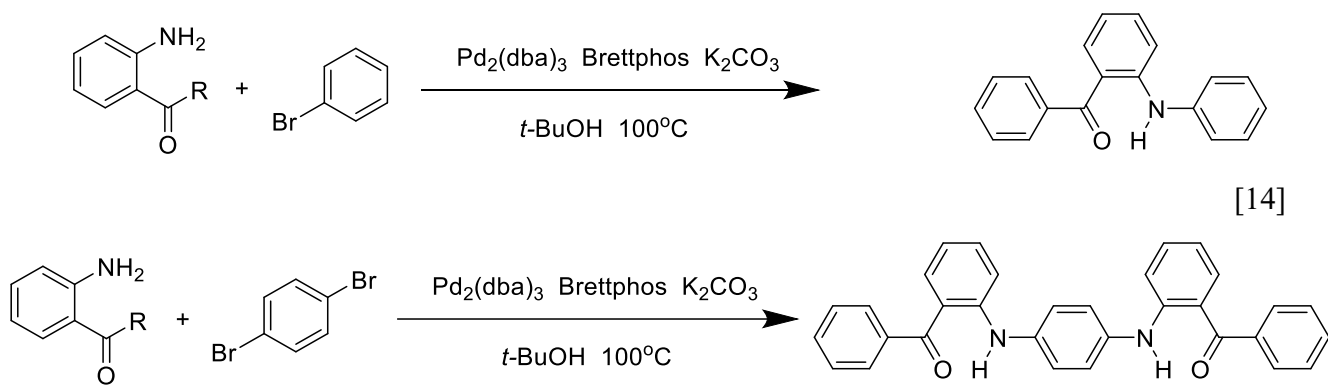

Scheme S-A.3. Synthetic route of TAA derivatives.<smiles>COc1cccc(OC)c1C(=O)c1cc2ccccc2cc1N</smiles>

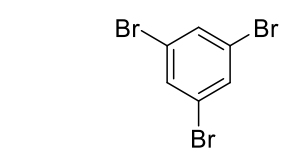

$\mathrm{Pd}_{2}(\mathrm{dba})_{3}$ Brettphos $\mathrm{K}_{2} \mathrm{CO}_{3}$

$t$-BuOH $100^{\circ} \mathrm{C}$

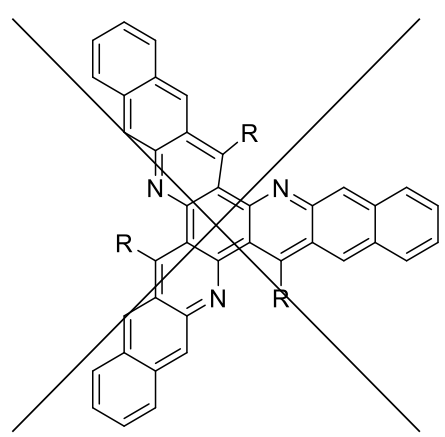

Scheme S-A.4. Unsuccessful synthetic route of TAA derivatives. 

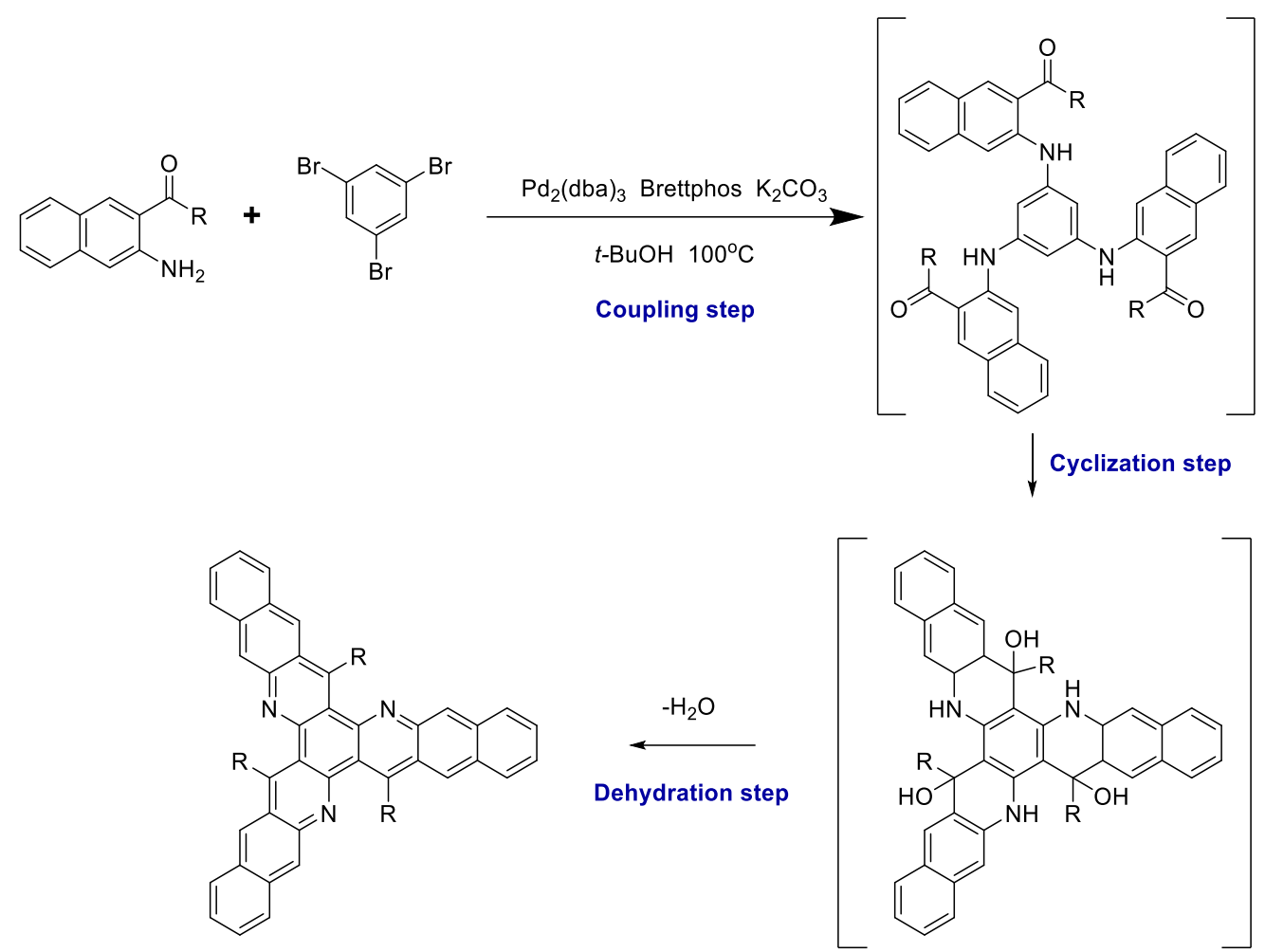

Scheme S-A.5. Plausible steps and intermediates. 


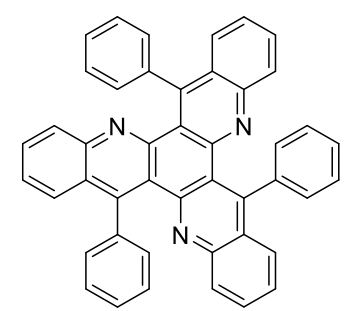

\section{6,12,18-triphenyl-5,11,17-triazatrinaphthylene (TAN-Ph)}

$0.94 \mathrm{~g}$ (3.00 mmol, 1.0 eq.) of 1,3,5-tribromobenzene, $1.95 \mathrm{~g}$ (9.85 mmol, 3.3 eq.) of 2-aminobenzophenone , $2.48 \mathrm{~g}$ (17.92 mmol, 6.0 eq.) of potassium carbonate, $0.027 \mathrm{~g}\left(0.03 \mathrm{mmol}, 0.01\right.$ eq.) of $\operatorname{Pd}_{2}(\mathrm{dba})_{3}$ and $0.048 \mathrm{~g}(0.09 \mathrm{mmol}, 0.03 \mathrm{eq}$.) of BrettPhos were added into a dry round-bottom flask. Then, $30 \mathrm{~mL} t$-butanol were added into the flask. The mixture was stirred at reflux for 72 hours under nitrogen by an aluminium heating block. After cooling to room temperature, the reaction mixture was filtered and the filtrate was dried under reduced pressure. The residue was purified by column chromatography over silica gel using pentane:dichloromethane (4:1) as eluent to yield $1.20 \mathrm{~g}$ of light yellow solid $(66 \%)$.

${ }^{1} \mathrm{H}$ NMR (300 MHz, $\left.\mathrm{CDCl}_{3}\right): \delta=7.58(\mathrm{~m}, 15 \mathrm{H}$; Ar-H), $7.36(\mathrm{~m}, 9 \mathrm{H} ; \mathrm{Ar}-\mathrm{H}), 7.16(\mathrm{~d}, 3 \mathrm{H}, J=7.9 \mathrm{~Hz}$; Ar-H).

${ }^{13} \mathrm{C}$ NMR $\left(151 \mathrm{MHz}, \mathrm{CD}_{2} \mathrm{Cl}_{2}\right) \delta=150.1,148.8,146.7,142.6,130.3,129.9,129.6,128.5,128.2,127.7,127.0,126.8,123.5$ HRMS (ESI-TOF) m/z: [M + H] Calcd for $\mathrm{C}_{45} \mathrm{H}_{28} \mathrm{~N}_{3} 610.2277$; found 610.2272.

$\mathrm{Mp}:>400^{\circ} \mathrm{C}$.

NMR Spectra [1]

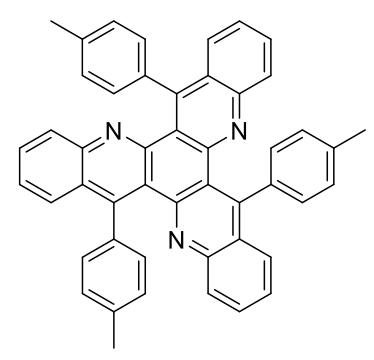

\section{6,12,18-tri-p-tolyl-5,11,17-triazatrinaphthylene (TAN-MePh)}

$0.13 \mathrm{~g}$ (0.41 mmol, 1.0 eq.) of 1,3,5-tribromobenzene, $0.31 \mathrm{~g}$ (1.47 mmol, 3.3 eq.) of 2-amino-4'-methylbenzophenone , $0.36 \mathrm{~g}$ (2.61 mmol, 6.0 eq.) of potassium carbonate, $0.004 \mathrm{~g} \quad\left(0.004 \mathrm{mmol}, 0.01\right.$ eq.) of $\mathrm{Pd}_{2}(\mathrm{dba})_{3}$ and $0.007 \mathrm{~g}(0.013$ mmol, 0.03 eq.) of BrettPhos were added into a dry round-bottom flask. $20 \mathrm{~mL} t$-butanol were added into the flask. The mixture was stirred at reflux for 72 hours under nitrogen by an aluminium heating block. After cooling to room temperature, the reaction mixture was filtered and the filtrate was dried under reduced pressure. The residue was then purified by column chromatography over silica gel with pentane:dichloromethane (7:3) as eluent to give $0.21 \mathrm{~g}$ of light yellow solid (74\%). ${ }^{1} \mathrm{H}$ NMR $\left(300 \mathrm{MHz}, \mathrm{CD}_{2} \mathrm{Cl}_{2}\right): \delta=7.61$ (ddd, 3H, $J=8.5,1.4,0.6 \mathrm{~Hz}$; Ar-H), 7.56 (ddd, 3H, $\left.J=8.3,5.7,1.4 \mathrm{~Hz} ; \mathrm{Ar}-\mathrm{H}\right)$, 7.37 (m, 9H; Ar-H), 7.22 (d, 6H, J=8.0 Hz; Ar-H), 7.17 (ddd, 3H, J=8.4, 1.3, 0.6 Hz; Ar-H), $2.56\left(\mathrm{~s}, 9 \mathrm{H} ; \mathrm{CH}_{3}\right)$.

${ }^{13} \mathrm{C} \mathrm{NMR}\left(75 \mathrm{MHz}, \mathrm{CD}_{2} \mathrm{Cl}_{2}\right): \delta=150.1,148.8,146.6,139.2,136.3,130.0,129.6,129.4,128.9,128.1,127.6,126.7,123.5$, 21.6.

HRMS (ESI-TOF) m/z: [M + H] + Calcd for $\mathrm{C}_{48} \mathrm{H}_{34} \mathrm{~N}_{3} 652.2747$; found 652.2737.

Mp: $268-270^{\circ} \mathrm{C}$

NMR Spectra [2]

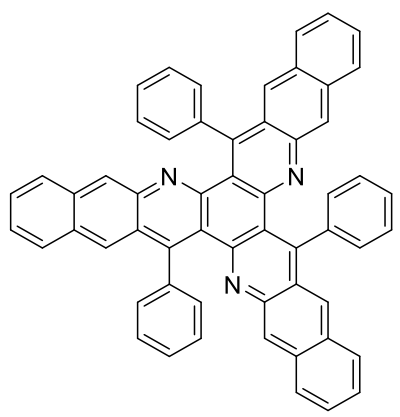




\section{7,15,23-triphenyl-6,14,22-triazatriantrylene (TAA-Ph)}

$0.096 \mathrm{~g}$ ( $0.30 \mathrm{mmol}, 1.0$ eq.) of 1,3,5-tribromobenzene, $0.25 \mathrm{~g}$ (1.01 mmol, 3.3 eq.) of 2-amino-3-benzoylnaphthalene, $0.25 \mathrm{~g}$ (1.83 mmol, 6.0 eq.) of potassium carbonate, $0.003 \mathrm{~g}$ ( $0.0031 \mathrm{mmol}, 0.01$ eq.) of $\mathrm{Pd}_{2}\left(\mathrm{dba}_{3}\right.$ and $0.005 \mathrm{~g}(0.0092$ mmol, 0.03 eq.) of BrettPhos were added into a dry round-bottom flask. Then, $20 \mathrm{~mL}$ of $t$-butanol were added into the flask. The mixture was stirred at reflux for 72 hours under nitrogen by an aluminium heating block. After cooling to room temperature, the reaction mixture was filtered and the filtrate was dried under reduced pressure. The residue was purified by column chromatography over silica gel using pentane:dichloromethane (7:3) as eluent to yield $0.20 \mathrm{~g}$ of light yellow solid $(87 \%)$.

${ }^{1} \mathrm{H}$ NMR $\left(300 \mathrm{MHz}, \mathrm{CDCl}_{3}\right): \delta=8.18(\mathrm{~s}, 3 \mathrm{H} ; \mathrm{Ar}-\mathrm{H}), 7.94$ (d, 3H, $\left.J=8.1 \mathrm{~Hz} ; \mathrm{Ar}-\mathrm{H}\right), 7.84$ (d, 3H, $\left.J=8.1 \mathrm{~Hz} ; \mathrm{Ar}-\mathrm{H}\right), 7.75$ (s, 3H; Ar-H), 7.68 (m, 9H; Ar-H), 7.45 (m, 12H; Ar-H).

${ }^{13} \mathrm{C}$ NMR $\left(150.9 \mathrm{MHz}, \mathrm{C}_{2} \mathrm{D}_{2} \mathrm{Cl}_{4}\right): \delta=150.6,148.5,142.6,141.5,133.8,131.7,129.2,128.8,128.2,128.1,127.2,127.1$, 126.6, 126.5, 126.4, 125.8, 122.6 .

HRMS (FD-TOF) m/z: [M+ H]+ Calcd for $\mathrm{C}_{57} \mathrm{H}_{33} \mathrm{~N}_{3}$ 759.2674; found 759.2696.

Mp: $>400^{\circ}$ C.NMR Spectra [3]

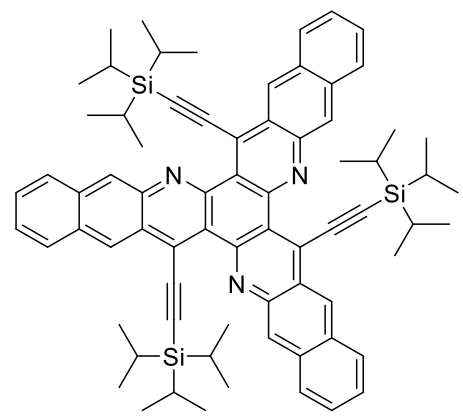

\section{7,15,23-tri(triisopropylsilylethynyl)-6,14,22-triazatriantrylene (TAA-Tips)}

$0.081 \mathrm{~g}(0.26 \mathrm{mmol}, 1.0$ eq. $)$ of 1,3,5-tribromobenzene, $0.30 \mathrm{~g}(0.85 \mathrm{mmol}, 3.3 \mathrm{eq}$.) of 1-(3-(2-aminonaphthalenyl)-3(triisopropylsilyl)-2-propyn-1-one, $0.21 \mathrm{~g}(1.50 \mathrm{mmol}, 6.0 \mathrm{eq}$.) of potassium carbonate, $0.002 \mathrm{~g}$ ( $0.0026 \mathrm{mmol}, 0.01$ eq.) of $\mathrm{Pd}_{2}(\mathrm{dba})_{3}$ and $0.004 \mathrm{~g}(0.0078 \mathrm{mmol}, 0.03$ eq. $)$ of BrettPhos were added into a dry round-bottom flask. Then, $20 \mathrm{~mL}$ of $t$-butanol were added into the flask. The mixture was stirred at reflux for 72 hours under nitrogen by an aluminium heating block. After cooling to room temperature, the reaction mixture was filtered and the filtrate was dried under reduced pressure. The residue was purified by column chromatography over silica gel with pentane:dichloromethane (4:1) as eluent to give $0.20 \mathrm{~g}$ of light yellow solid (74\%).

${ }^{1} \mathrm{H}$ NMR (300 MHz, CDCl 3$): \delta=9.49$ (s, 3H; Ar-H), 9.01 (s, 3H; Ar-H), 8.11 (m, 6H; Ar-H), 7.60 (m, 6H; Ar-H), $1.50(\mathrm{~m}$, $9 \mathrm{H} ; \mathrm{CH}), 1.36\left(\mathrm{~d}, 54 \mathrm{H}, J=6.8 \mathrm{~Hz} ; \mathrm{CH}_{3}\right)$.

${ }^{13} \mathrm{C}$ NMR $\left(150.9 \mathrm{MHz}, \mathrm{C}_{2} \mathrm{D}_{2} \mathrm{Cl}_{4}\right): \delta=149.7,143.2,134.2,132.5,128.8,128.0,127.7,127.6,127.3,127.0,127.0,126.6$, 125.2, 111.28, 104.6, 19.0, 11.7 .

HRMS (ESI-TOF) m/z: [M + H] Calcd for $\mathrm{C}_{72} \mathrm{H}_{82} \mathrm{~N}_{3} \mathrm{Si}_{3}$ 1072.5811; found 1072.5802 .

Mp: $>400^{\circ} \mathrm{C}$.

NMR Spectra [4] 


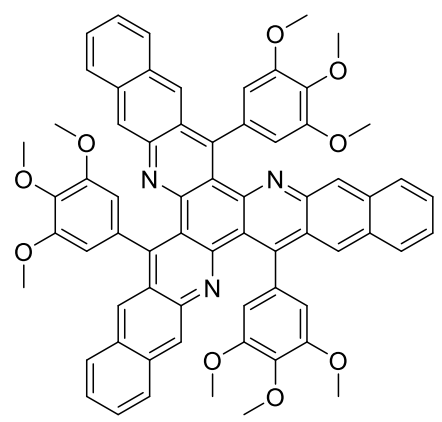

\section{7,15,23-tri(3,4,5-trimethoxyphenyl)-6,14,22-triazatriantrylene (TAA-OMePh)}

$0.34 \mathrm{~g}$ (1.08 mmol, 1.0 eq.) of 1,3,5-tribromobenzene, $1.20 \mathrm{~g}$ (3.56 mmol, 3.3 eq.) of 2-amino-3-(3,4,5trimethoxy)benzoylnaphthalene, $0.90 \mathrm{~g}(6.50 \mathrm{mmol}, 6.0 \mathrm{eq}$.) of potassium carbonate, $0.010 \mathrm{~g} \quad(0.011 \mathrm{mmol}, 0.01 \mathrm{eq}$.) of $\mathrm{Pd}_{2}(\mathrm{dba})_{3}$ and $0.018 \mathrm{~g}(0.032 \mathrm{mmol}, 0.03$ eq.) of BrettPhos were added into a dry round-bottom flask. Then, $20 \mathrm{~mL}$ of $t$ butanol were added into the flask. The mixture was stirred at reflux for 72 hours under nitrogen by an aluminium heating block. After cooling to room temperature, the reaction mixture was filtered, and the filtrate was dried under reduced pressure. The residue was purified by column chromatography over silica gel with dichloromethane:ethyl acetate (19:1) as eluent to give $0.40 \mathrm{~g}$ of yellow solid (36\%).

${ }^{1} \mathrm{H}$ NMR $\left(300 \mathrm{MHz}, \mathrm{CD}_{2} \mathrm{Cl}_{2}\right.$ ): $\delta=8.39$ (s, 3H; Ar-H), 7.98 (s, 3H; Ar-H), 7.96 (d, 6H, J=7.8 Hz; Ar-H), 7.49 (m, 6H; Ar$\mathrm{H}), 6.73(\mathrm{~s}, 6 \mathrm{H} ; \mathrm{Ar}-\mathrm{H}), 4.17\left(\mathrm{~s}, 9 \mathrm{H} ; \mathrm{CH}_{3}\right), 3.78\left(\mathrm{~s}, 18 \mathrm{H} ; \mathrm{CH}_{3}\right)$.

${ }^{13} \mathrm{C}$ NMR $\left(150.9 \mathrm{MHz}, \mathrm{C}_{2} \mathrm{D}_{2} \mathrm{Cl}_{4}\right): \delta=153.4,150.4,148.01,142.8,137.17,137.0,133.9,131.8,129.0,127.8,127.4,127.0$ (x2 CH, see HSQC), 126.4, 126.0, 122.5, 106.9, 61.4, 56.4.

HRMS (ESI-TOF) $\mathrm{m} / \mathrm{z}$ : [M + H] Calcd for $\mathrm{C}_{66} \mathrm{H}_{52} \mathrm{O}_{9} \mathrm{~N}_{3}$ 1030.3698; found 1030.3664.

Mp: $331-334^{\circ} \mathrm{C}$

NMR Spectra [5]

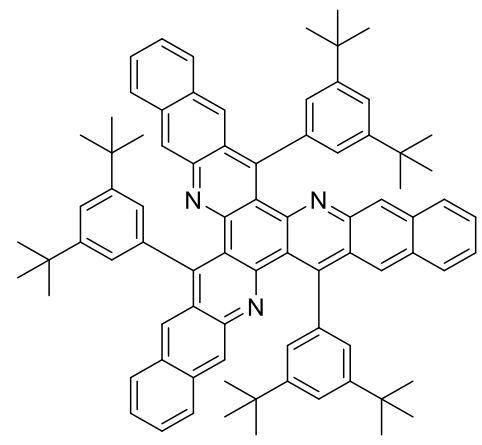

\section{7,15,23-tri(3,5-di-tert-butylphenyl)-6,14,22-triazatriantrylene (TAA-tBuPh)}

$0.11 \mathrm{~g}$ (0.35 mmol, 1.0 eq.) of 1,3,5-tribromobenzene, $0.41 \mathrm{~g}(1.15 \mathrm{mmol}, 3.3$ eq.) of (2-amino-3-(3,5-di-tertbutyl)benzoylnaphthalene, $0.29 \mathrm{~g}(2.10 \mathrm{mmol}, 6.0 \mathrm{eq}$. $)$ of potassium carbonate, $0.0032 \mathrm{~g}(0.0035 \mathrm{mmol}, 0.01 \mathrm{eq}$. $)$ of $\mathrm{Pd}_{2}(\mathrm{dba})_{3}$ and $0.0056 \mathrm{~g}(0.011 \mathrm{mmol}, 0.03$ eq. $)$ of BrettPhos were added into a dry round-bottom flask. Then, $20 \mathrm{~mL}$ of $t$ butanol were added into the flask. The mixture was stirred at reflux for 72 hours under nitrogen by an aluminium heating block. After cooling to room temperature, the reaction mixture was filtered, and the filtrate was dried under reduced pressure. The residue was purified by column chromatography over silica gel with dichloromethane:ethyl acetate (19:1) as eluent to give $0.20 \mathrm{~g}$ of yellow solid (53\%).

${ }^{1} \mathrm{H}$ NMR (300 MHz, CDCl $): \delta=8.37$ (s, 3H; Ar-H), 7.88 (t, $6 \mathrm{H}, J=8.0 \mathrm{~Hz}$; Ar-H), 7.74 (dd, 6H, $J=4.7,3.0 \mathrm{~Hz}$; Ar-H), 7.45 (ddd, $6 \mathrm{H}, J=19.0,10.8,6.2 \mathrm{~Hz}$; Ar-H), 7.32 (d, $6 \mathrm{H}, J=1.7 \mathrm{~Hz} ; \mathrm{Ar}-\mathrm{H}), 1.38$ (s, $\left.54 \mathrm{H} ; \mathrm{CH}_{3}\right)$.

${ }^{13} \mathrm{C}$ NMR $\left(75 \mathrm{MHz}, \mathrm{CDCl}_{3}\right): \delta=151.2,150.9,149.9,143.1,140.9,134.1,132.1,129.3,128.1,127.8,127.5,126.8,126.6$, 125.6, 124.1, 123.3, 120.4, 35.2, 31.9

HRMS (ESI-TOF) m/z: [M + H]+ Calcd for $\mathrm{C}_{81} \mathrm{H}_{82} \mathrm{~N}_{3}$ 1096.6503; found 1096.6470 .

$\mathrm{Mp}:>400^{\circ} \mathrm{C}$.

NMR Spectra [6] 


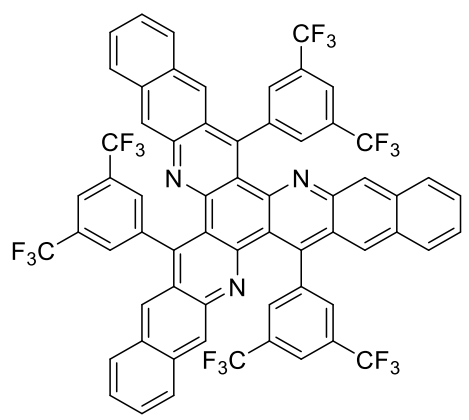

\section{7,15,23-tri(3,5-di-trifluoromethylphenyl)-6,14,22-triazatriantrylene (TAA-CF 3 Ph)}

$0.20 \mathrm{~g}$ (0.63 mmol, 1.0 eq.) of 1,3,5-tribromobenzene, $0.80 \mathrm{~g}$ (2.09 mmol, 3.3 eq.) of 2-amino-3-(3,5bis(trifluoromethyl))benzoylnaphthalene, $0.53 \mathrm{~g}(3.81 \mathrm{mmol}, 6.0 \mathrm{eq}$.) of potassium carbonate, $0.0058 \mathrm{~g}(0.0063 \mathrm{mmol}$, 0.01 eq.) of $\mathrm{Pd}_{2}(\mathrm{dba})_{3}$ and $0.010 \mathrm{~g}(0.019 \mathrm{mmol}, 0.03$ eq.) of BrettPhos were added into a dry round-bottom flask. Then, $20 \mathrm{~mL}$ of $t$-butanol were added into the flask. The mixture was stirred at reflux for 72 hours under nitrogen by an aluminium heating block. After cooling to room temperature, the reaction mixture was filtered, and the filtrate was dried under reduced pressure. The residue was finally purified by column chromatography over silica gel using dichloromethane:ethyl acetate (19:1) as eluent to give $0.32 \mathrm{~g}$ of yellow solid $(42 \%)$.

${ }^{1} \mathrm{H}$ NMR $\left(300 \mathrm{MHz}, \mathrm{CDCl}_{3}\right.$ ): $\delta=8.28$ (s, 3H; Ar-H), 8.01 (s, 6H; Ar-H), 7.92 (m, 9H; Ar-H), 7.68 (s, 3H; Ar-H), 7.53 (dddd, $6 \mathrm{H}, J=9.5,7.9,6.6,1.1 \mathrm{~Hz} ; \mathrm{Ar}-\mathrm{H}$ ).

${ }^{13} \mathrm{C}$ NMR $\left(75 \mathrm{MHz}, \mathrm{CD}_{2} \mathrm{Cl}_{2}\right): \delta=149.6,145.2,144.0,142.4,134.5,132.4,131.9,131.4,129.9,128.7,127.4,127.1,126.8$, $126.5,125.8,122.7,120.7$.

HRMS (ESI-TOF) m/z: [M + H] Calcd for $\mathrm{C}_{63} \mathrm{H}_{28} \mathrm{~N}_{3} \mathrm{~F}_{18}$ 1168.1990, found 1168.1960.

NMR Spectra [7]

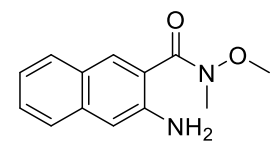

\section{2-amino-N-methoxy-N-methyl-3-naphthamide}

$1.00 \mathrm{~g}$ (5.34 mmol, 1.0 eq.) of 3-amino-2-naphthoic acid was dissolved in $50 \mathrm{~mL}$ dichloromethane and cooled down to $0{ }^{\circ} \mathrm{C} .1 .72 \mathrm{~g}(6.41 \mathrm{mmol}, 1.2 \mathrm{eq}$.) of diphenyl chlorophosphate were added dropwise and stirred for $10 \mathrm{~min}$. Then, $1.30 \mathrm{~g}$ (12.82 mmol, 2.4 eq.) of triethylamine were added and the mixture was stirred for 10 min following by addition of $0.62 \mathrm{~g}$ (6.41 mmol, 1.2 eq.) of $\mathrm{N}, \mathrm{O}$-dimethylhydroxylamine hydrochloride. After overnight stirring and return to room temperature, the reaction mixture was poured into water and extracted with dichloromethane, then the organic phase was collected and the organic solvent was removed under reduced pressure. The residue was finally purified by column chromatography over silica gel with dichloromethane:ethyl acetate $(1: 1)$ as eluent to give $0.98 \mathrm{~g}$ of brown oil $(80 \%)$.

${ }^{1} \mathrm{H}$ NMR $\left(600 \mathrm{MHz}, \mathrm{CDCl}_{3}\right): \delta=7.86(\mathrm{~s}, 1 \mathrm{H} ; \mathrm{Ar}-\mathrm{H}), 7.69(\mathrm{dd}, 1 \mathrm{H}, J=8.2,0.6 \mathrm{~Hz} ; \mathrm{Ar}-\mathrm{H}), 7.57(\mathrm{~d}, 1 \mathrm{H}, J=8.3 \mathrm{~Hz} ; \mathrm{Ar}-\mathrm{H})$, 7.40 (ddd, $1 \mathrm{H}, J=8.2,6.8,1.3 \mathrm{~Hz} ; \mathrm{Ar}-\mathrm{H}), 7.23(\mathrm{~m}, 1 \mathrm{H} ; \mathrm{Ar}-\mathrm{H}), 7.03(\mathrm{~s}, 1 \mathrm{H} ; \mathrm{Ar}-\mathrm{H}), 4.63(\mathrm{~s}, 2 \mathrm{H} ; \mathrm{NH}), 3.58\left(\mathrm{~s}, 3 \mathrm{H} ; \mathrm{CH}_{3}\right)$, $3.39\left(\mathrm{~s}, 3 \mathrm{H} ; \mathrm{CH}_{3}\right)$.

${ }^{13} \mathrm{C}$ NMR (150 MHz, $\left.\mathrm{CD}_{2} \mathrm{Cl}_{2}\right): \delta=169.4,143.2,135.58,129.3,128.5,127.7,126.7,125.6,123.0,110.4,61.4,34.2$.

HRMS (ESI-Ion trap) m/z: [M + H] + Calcd for $\mathrm{C}_{13} \mathrm{H}_{15} \mathrm{~N}_{2} \mathrm{O}_{2} 231.1128$, found 231.1125.

NMR Spectra [8] 


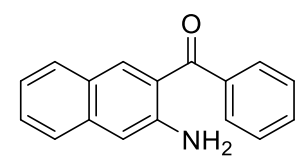

\section{2-amino-3-benzoylnaphthalene}

$1.30 \mathrm{~g}$ (5.91 mmol, $1.0 \mathrm{eq}$.) of 2-amino-N-methoxy-N-methyl-3-naphthamide were dissolved in $30 \mathrm{~mL}$ of freshly distilled THF and cooled to $0{ }^{\circ} \mathrm{C}$. Then, $8.8 \mathrm{~mL}(17.7 \mathrm{mmol}, 3 \mathrm{eq}$.) of $2 \mathrm{~mol} / \mathrm{L}$ phenylmagnesium chloride solution were added dropwise to the solution. The mixture was stirred at $0^{\circ} \mathrm{C}$ for 5 hours, then carefully quenched with $5 \mathrm{~mL}$ of water. After THF evaporation under reduced pressure, the residue was dissolved in dichloromethane and washed with water. Then the organic phase was collected and the organic solvent was removed under reduced pressure. The residue was then purified by column chromatography over silica gel using dichloromethane as eluent to give $1.00 \mathrm{~g}$ of orange powder (68\%).

${ }^{1} \mathrm{H}$ NMR $\left(300 \mathrm{MHz}, \mathrm{CDCl}_{3}\right): \delta=7.98(\mathrm{~s}, 1 \mathrm{H} ; \mathrm{Ar}-\mathrm{H}), 7.80(\mathrm{~m}, 2 \mathrm{H} ; \mathrm{Ar}-\mathrm{H}), 7.53(\mathrm{~m}, 6 \mathrm{H} ; \mathrm{Ar}-\mathrm{H}), 7.19$ (ddd, $1 \mathrm{H}, J=8.1,6.7$, $1.2 \mathrm{~Hz} ; \mathrm{Ar}-\mathrm{H}), 7.03$ (s, 1H; Ar-H), 5.42 (s, 2H; NH).

${ }^{13} \mathrm{C}$ NMR $\left(75 \mathrm{MHz}, \mathrm{CDCl}_{3}\right): \delta=199.1,146.1,139.5,137.1,136.1,132.1,130.0,129.3,129.1,128.3,125.8,125.3,122.8$, 122.7, 110.5 .

HRMS (ESI-TOF) m/z: [M + Na]+ Calcd for $\mathrm{C}_{17} \mathrm{H}_{13} \mathrm{NONa} 270.0889$; found 270.0899.

NMR Spectra [9]

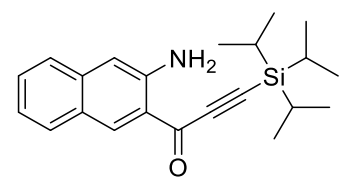

\section{1-(3-(2-aminonaphthalenyl)-3-(triisopropylsilyl)-2-propyn-1-one}

$0.66 \mathrm{~g}$ (3.60 mmol, 3.0 eq.) of triisopropylsilylacetylene were dissolved in $20 \mathrm{~mL}$ of freshly distilled THF and cooled down to $-78^{\circ} \mathrm{C}$. Then, $2.25 \mathrm{~mL}\left(3.60 \mathrm{mmol}, 3.0\right.$ eq.) of $1.6 \mathrm{M} \mathrm{n}$-BuLi solution were added drop by drop. After stirring $-78^{\circ} \mathrm{C}$ for 2 hours, $0.28 \mathrm{~g}$ (1.20 mmol, 1.0 eq.) of 2-amino-N-methoxy-N-methyl-3-naphthamide, dissolved in $20 \mathrm{~mL}$ of THF, were added to the mixture drop by drop. Then, the mixture was stirred and was kept at room temperature overnight. After the reaction, $10 \mathrm{~mL}$ of water were slowly added to quench the excess of organolithium compounds, and then THF was removed under reduced pressure. $150 \mathrm{~mL}$ of water and $150 \mathrm{~mL}$ of dichloromethane were added to the residue. The aqueous phase was extracted three times with dichloromethane. The combined solution was concentrated under reduced pressure. The residue was purified by column chromatography over silica gel with dichloromethane as eluent to give $0.31 \mathrm{~g}$ of orange solid $(65 \%)$.

${ }^{1} \mathrm{H}$ NMR $\left(300 \mathrm{MHz}, \mathrm{CDCl}_{3}\right): \delta=8.87(\mathrm{~s}, 1 \mathrm{H} ; \mathrm{Ar}-\mathrm{H}), 7.69$ (d, $\left.1 \mathrm{H}, J=8.3 \mathrm{~Hz} ; \mathrm{Ar}-\mathrm{H}\right), 7.52(\mathrm{~d}, 1 \mathrm{H}, J=8.3 \mathrm{~Hz} ; \mathrm{Ar}-\mathrm{H}), 7.42$ $(\mathrm{m}, 1 \mathrm{H} ; \mathrm{Ar}-\mathrm{H}), 7.20(\mathrm{ddd}, 1 \mathrm{H}, J=8.1,6.7,1.2 \mathrm{~Hz} ; \mathrm{Ar}-\mathrm{H}), 6.92(\mathrm{~s}, 1 \mathrm{H} ; \operatorname{Ar}-\mathrm{H}), 5.82 \quad(\mathrm{~s}, 2 \mathrm{H} ; \mathrm{NH}), 1.22(\mathrm{~m}, 21 \mathrm{H}$; $\left.\mathrm{CH}_{3} \mathrm{CHCH}_{3}\right)$.

${ }^{13} \mathrm{C}$ NMR $\left(75 \mathrm{MHz}, \mathrm{CDCl}_{3}\right): \delta=179.7,146.3,138.2,138.0,129.9,129.7,126.0,125.3,122.8,122.3,110.1,103.5,97.4$, $18.8,11.3$.

HRMS (ESI-TOF) m/z: [M + H]+ Calcd for $\mathrm{C}_{22} \mathrm{H}_{30} \mathrm{NOSi}$ 352.2091; found 352.2097.

NMR Spectra [10] 


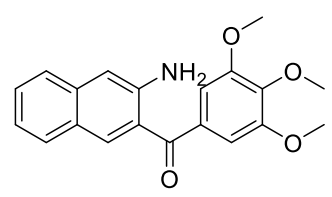

\section{2-amino-3-(3,4,5-trimethoxy)benzoylnaphthalene}

$3.86 \mathrm{~g}$ (15.63 mmol, 3.0 eq.) of 5-bromo-1,2,3-trimethoxybenzene were dissolved in $25 \mathrm{~mL}$ of freshly distilled THF and cooled down to $-78^{\circ} \mathrm{C}$. Then, $6.25 \mathrm{~mL}(15.63 \mathrm{mmol}, 3.0$ eq. $)$ of $2.5 \mathrm{M} \mathrm{n}$-BuLi solution were added drop by drop and the mixture was stirred at $-78^{\circ} \mathrm{C}$ for 2 hours. After addition of $1.20 \mathrm{~g}(5.21 \mathrm{mmol}, 1.0$ eq. $)$ of 2-amino-N-methoxy-N-methyl3-naphthamide, again dissolved in $20 \mathrm{~mL}$ of THF drop by drop, the mixture was stirred and was allowed to rise its temperature to $-10{ }^{\circ} \mathrm{C}$ in 3 hours. After the reaction, $10 \mathrm{~mL}$ of water were carefully added to quench the excess lithium compound and the resulting mixture was concentrated under reduced pressure. Then, $200 \mathrm{~mL}$ of water and $200 \mathrm{~mL}$ of dichloromethane were added, and the aqueous phase was extracted three times with dichloromethane. The combined solution was concentrated under reduced pressure. The residue was purified by column chromatography over silica gel with dichloromethane:ethyl acetate (9:1) as eluent to give $1.60 \mathrm{~g}$ of yellow solid $(90 \%)$.

${ }^{1} \mathrm{H}$ NMR $\left(600 \mathrm{MHz}, \mathrm{CDCl}_{3}\right): \delta=8.00(\mathrm{~s}, 1 \mathrm{H} ; \mathrm{Ar}-\mathrm{H}), 7.65(\mathrm{~d}, 1 \mathrm{H}, J=8.2 \mathrm{~Hz} ; \mathrm{Ar}-\mathrm{H}), 7.58(\mathrm{~d}, 1 \mathrm{H}, J=7.9 \mathrm{~Hz} ; \mathrm{Ar}-\mathrm{H}), 7.44$ (ddd, $1 \mathrm{H}, J=9.7,5.5,2.1 \mathrm{~Hz}$; Ar-H), 7.20 (ddd, $1 \mathrm{H}, J=8.1,6.8,1.2 \mathrm{~Hz}$; Ar-H), 7.05 (s, 3H; Ar-H), 5.42 (s, 2H; NH), 3.96 $\left(\mathrm{s}, 3 \mathrm{H} ; \mathrm{CH}_{3}\right), 3.86\left(\mathrm{~s}, 6 \mathrm{H} ; \mathrm{CH}_{3}\right)$.

${ }^{13} \mathrm{C}$ NMR $\left(150.9 \mathrm{MHz}, \mathrm{CDCl}_{3}\right): \delta=197.9,153.0,145.9,141.9,137.0,135.5,134.4,129.2,125.9,125.4,123.2,123.0$, $110.5,107.7,61.1,56.5$.

HRMS (ESI-Ion trap) m/z: [M+ H]+ Calcd for $\mathrm{C}_{20} \mathrm{H}_{20} \mathrm{NO}_{4}$ 338.1387; found 338.1378.

NMR Spectra [11]

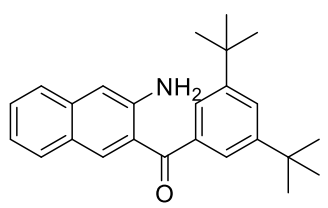

\section{2-amino-3-(3,5-di-tert-butyl)benzoylnaphthalene}

$3.51 \mathrm{~g}$ (13.03 mmol, 3.0 eq.) of 1-bromo-3,5-di-tert-butylbenzene were dissolved in $25 \mathrm{~mL}$ of freshly distilled THF and cooled down to $-78^{\circ} \mathrm{C}$. Then, $5.21 \mathrm{~mL}(13.03 \mathrm{mmol}, 3.0 \mathrm{eq}$.) of $2.5 \mathrm{M} \mathrm{n}$-BuLi solution were added drop by drop, and the mixture was stirred at $-78{ }^{\circ} \mathrm{C}$ for 2 hours. $1.00 \mathrm{~g}(4.34 \mathrm{mmol}, 1.0 \mathrm{eq}$.) of 2-amino-N-methoxy-N-methyl-3-naphthamide dissolved in $20 \mathrm{~mL}$ of THF were then added to the mixture drop by drop. The mixture was stirred and allowed to heat to $10{ }^{\circ} \mathrm{C}$ in 3 hours. After the reaction, $10 \mathrm{~mL}$ of water was slowly added to quench the excess of lithium reagent, and then THF was removed under reduced pressure. $200 \mathrm{~mL}$ of water and $200 \mathrm{~mL}$ of dichloromethane were added, and the aqueous phase was extracted three times with dichloromethane. The combined solution was concentrated under reduced pressure. The residue was purified by column chromatography over silica gel with cyclohexane:ethyl acetate (7:3) as eluent to give $0.4 \mathrm{~g}$ of yellow solid $(26 \%)$.

${ }^{1} \mathrm{H}$ NMR $\left(300 \mathrm{MHz}, \mathrm{CDCl}_{3}\right): \delta=8.05(\mathrm{~s}, 1 \mathrm{H} ; \mathrm{Ar}-\mathrm{H}), 7.70(\mathrm{~m}, 1 \mathrm{H} ; \mathrm{Ar}-\mathrm{H}), 7.67(\mathrm{~d}, 2 \mathrm{H}, J=1.8 \mathrm{~Hz} ; \mathrm{Ar}-\mathrm{H}), 7.60(\mathrm{dd}, 2 \mathrm{H}, J$ $=11.1,8.3 \mathrm{~Hz} ; \mathrm{Ar}-\mathrm{H}), 7.44$ (ddd, 1H, $J=8.3,6.8,1.2 \mathrm{~Hz}$; Ar-H), 7.19 (ddd, 1H, J = 8.1, 6.8, $1.2 \mathrm{~Hz}$; Ar-H), 7.05 (s, $1 \mathrm{H}$; Ar-H), $5.56(\mathrm{~s}, 2 \mathrm{H} ; \mathrm{NH}), 1.39\left(\mathrm{~s}, 18 \mathrm{H} ; \mathrm{CH}_{3}\right)$.

${ }^{13} \mathrm{C}$ NMR $\left(75 \mathrm{MHz}, \mathrm{CDCl}_{3}\right): \delta=199.9,150.9,146.3,138.8,137.0,136.4,129.2,129.1,126.2,125.9,125.3,124.6,123.1$, $122.8,110.4,35.1,31.5$.

HRMS (ESI-Ion trap) m/z: [M + H]+ Calcd for $\mathrm{C}_{25} \mathrm{H}_{30} \mathrm{NO} 360.2322$; found 360.2314.

NMR Spectra [12] 


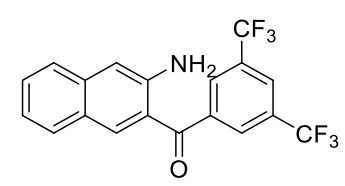

\section{2-amino-3-(3,5-bis(trifluoromethyl))benzoylnaphthalene}

$3.82 \mathrm{~g}$ (13.03 mmol, 3.0 eq.) of 1-bromo-3,5-bis(trifluoromethyl)benzene were dissolved in $25 \mathrm{~mL}$ of freshly distilled THF and cooled down to $-78{ }^{\circ} \mathrm{C}$. Then, $5.21 \mathrm{~mL}(13.03 \mathrm{mmol}, 3.0$ eq.) of $2.5 \mathrm{M} \mathrm{n}$-BuLi solution were added drop by drop and the mixture was stirred at $-78{ }^{\circ} \mathrm{C}$ for 2 hours. After addition drop by drop of $1.00 \mathrm{~g}(4.34 \mathrm{mmol}, 1.0 \mathrm{eq}$.) of 2 -amino-Nmethoxy-N-methyl-3-naphthamide dissolved in $20 \mathrm{~mL}$ of THF, the mixture was stirred and was allowed to heat to $-10^{\circ} \mathrm{C}$ in 3 hours. After the reaction, $10 \mathrm{~mL}$ of water were carefully added to quench the excess lithium compound, and then THF was removed under reduced pressure. $200 \mathrm{~mL}$ of water and $200 \mathrm{~mL}$ of dichloromethane were added, and the aqueous phase was extracted three times with dichloromethane. The combined solution was concentrated under reduced pressure and the residue was purified by column chromatography over silica gel with dichloromethane:cycohexane $(6: 4)$ as eluent to give $0.6 \mathrm{~g}$ of yellow solid $(36 \%)$.

${ }^{1} \mathrm{H}$ NMR $\left(300 \mathrm{MHz}, \mathrm{CDCl}_{3}\right): \delta=8.20(\mathrm{~s}, 2 \mathrm{H} ; \mathrm{Ar}-\mathrm{H}), 8.10(\mathrm{~s}, 1 \mathrm{H} ; \mathrm{Ar}-\mathrm{H}), 7.85(\mathrm{~s}, 1 \mathrm{H} ; \mathrm{Ar}-\mathrm{H}), 7.60(\mathrm{~m}, 2 \mathrm{H} ; \mathrm{Ar}-\mathrm{H}), 7.47(\mathrm{t}$, $1 \mathrm{H}, J=7.6 \mathrm{~Hz}$; Ar-H), 7.22 (t, $1 \mathrm{H}, J=7.5 \mathrm{~Hz}$; Ar-H), 7.14 (s, 1H; Ar-H), 5.68 (s, 2H; NH).

${ }^{13} \mathrm{C}$ NMR (75 MHz, $\left.\mathrm{CDCl}_{3}\right): \delta=195.89,146.27,141.56,137.76,136.27,132.14\left(\mathrm{q},{ }^{2} \mathrm{~J}_{(\mathrm{C}-\mathrm{H})}=32 \mathrm{~Hz}\right), 130.02,129.73(\mathrm{q}$, $\left.{ }^{3} \mathbf{J}_{(\mathrm{C}-\mathrm{H})}=4 \mathrm{~Hz}\right), 129.5,125.8,125.5,125.3\left(\right.$ sextuplet, $\left.{ }^{3} \mathrm{~J}_{(\mathrm{C}-\mathrm{H})}=4 \mathrm{~Hz}\right), 123.3,123.1\left(\mathrm{q},{ }^{1} \mathrm{~J}_{(\mathrm{C}-\mathrm{H})}=273 \mathrm{~Hz}\right), 121.2,111.1$.

HRMS (ESI-Ion trap) m/z: [M + H] Calcd for $\mathrm{C}_{19} \mathrm{H}_{12} \mathrm{~F}_{6} \mathrm{NO} 384.0818$; found 384.0810.

NMR Spectra [13]

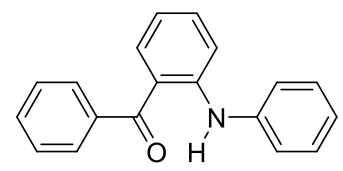

\section{2-Phenylaminobenzophenone}

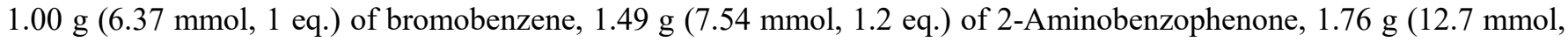
2.0 eq.) of potassium carbonate, $0.020 \mathrm{~g}$ ( $0.022 \mathrm{mmol}, 0.0035$ eq.) of $\mathrm{Pd}_{2}(\mathrm{dba})_{3}$ and $0.030 \mathrm{~g}(0.056 \mathrm{mmol}, 0.0088 \mathrm{eq}$.) of BrettPhos were added into a dry round-bottom flask. Then, $20 \mathrm{~mL}$ of $t$-butanol were added into the flask. The mixture was stirred at reflux for 72 hours under nitrogen by an aluminium heating block. After cooling to room temperature, the reaction mixture was filtered, and the filtrate was dried under reduced pressure. The residue was finally purified by column chromatography over silica gel using dichloromethane:pentane (1:3) as eluent to give $1.29 \mathrm{~g}$ of yellow solid (74\%).

${ }^{1} \mathrm{H}$ NMR $\left(300 \mathrm{MHz}, \mathrm{CDCl}_{3}\right): \delta=10.18(\mathrm{~s}, 1 \mathrm{H} ; \mathrm{N}-\mathrm{H}), 7.74(\mathrm{~m}, 2 \mathrm{H}), 7.54(\mathrm{~m}, 4 \mathrm{H}), 7.36(\mathrm{~m}, 6 \mathrm{H}), 7.12(\mathrm{~m}, 1 \mathrm{H}), 6.73(\mathrm{~m}$, $1 \mathrm{H})$.

${ }^{13} \mathrm{C}$ NMR $\left(75 \mathrm{MHz}, \mathrm{CDCl}_{3}\right): \delta=199.2,148.1,140.6,139.9,135.1,134.3,131.5,129.5,129.5,128.2,123.6,122.3,119.8$, 116.7, 114.7.

HRMS (ESI-Ion trap) m/z: [M + Na]+ Calcd for $\mathrm{C}_{19} \mathrm{H}_{15} \mathrm{NONa} 296.1046$, found 296.1034.

NMR Spectra [14]

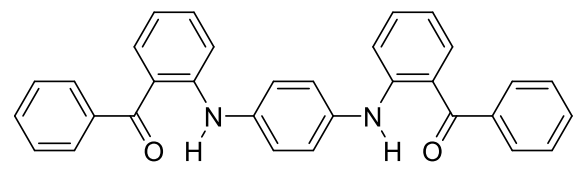




\section{5. [1,4-Phenylenebis(imino-2,1-phenylene)]bis(phenylmethanone)}

$0.76 \mathrm{~g}$ (3.2 mmol, 1 eq.) of 1,4-dibromobenzene, $1.49 \mathrm{~g}$ (7.54 mmol, 2.4 eq.) of 2-Aminobenzophenone, $1.76 \mathrm{~g}(12.7 \mathrm{mmol}$, 4.0 eq.) of potassium carbonate, $0.020 \mathrm{~g}$ ( $0.022 \mathrm{mmol}, 0.007$ eq.) of $\mathrm{Pd}_{2}(\mathrm{dba})_{3}$ and $0.030 \mathrm{~g}(0.056 \mathrm{mmol}, 0.017$ eq. $)$ of BrettPhos were added into a dry round-bottom flask. Then, $20 \mathrm{~mL}$ of $t$-butanol were added into the flask. The mixture was stirred at reflux for 72 hours under nitrogen by an aluminium heating block. After cooling to room temperature, the reaction mixture was filtered, and the filtrate was dried under reduced pressure. The residue was finally purified by column chromatography over silica gel using dichloromethane:pentane (1:1) as eluent to give $1.49 \mathrm{~g}$ of yellow solid (99\%).

${ }^{1} \mathrm{H}$ NMR (300 MHz, $\left.\mathrm{CDCl}_{3}\right): \delta=10.11(\mathrm{~s}, 2 \mathrm{H} ; \mathrm{N}-\mathrm{H}), 7.72(\mathrm{~m}, 4 \mathrm{H}), 7.52(\mathrm{~m}, 8 \mathrm{H}), 7.32(\mathrm{~m}, 8 \mathrm{H}), 6.70(\mathrm{~m}, 2 \mathrm{H})$.

${ }^{13} \mathrm{C} \mathrm{NMR}\left(75 \mathrm{MHz}, \mathrm{CDCl}_{3}\right): \delta=199.3,148.7,140.0,136.5,135.2,134.5,131.4,129.5,128.3,124.0,119.5,116.4,114.6$. HRMS (ESI-Ion trap) $\mathrm{m} / \mathrm{z}$ : [M + Na]+ Calcd for $\mathrm{C}_{32} \mathrm{H}_{24} \mathrm{~N}_{2} \mathrm{O}_{2} \mathrm{Na} 491.1730$, found 491.1718.

NMR Spectra [15] 


\section{B. Electronic properties}

UV-visible absorption spectra in solution were recorded with a UV-1650PC Shimadzu spectrophotometer. Cyclic voltammetry analyses were performed using a potentiostat/galvanostat Autolab PGSTAT100 and a three-electrode device. In the $\mathrm{CV}$ medium, the ferrocene/ferrocenium $\left(\mathrm{Fc} / \mathrm{Fc}^{+}\right)$couple has always been measured at $0,6 \mathrm{~V}$ vs $\mathrm{Ag} / \mathrm{AgCl}_{\text {sat }}{ }^{2}$. Taking into account the NHE formal potential on the fermi level $(-4.75 \mathrm{eV})$ and our reference electrode potential against NHE potential $(0.2 \mathrm{~V})$, LUMO has been estimated following the equation 1 and the half-wave reduction potential $\mathrm{E}_{/ 2}{ }^{\text {red }} \mathrm{vs}$ $\mathrm{Ag} / \mathrm{AgCl}:^{3}$.

$\mathrm{LUMO}=-4.95-\mathrm{E}_{1 / 2}^{\mathrm{red}}[\mathrm{eV}]$

where $\mathrm{E}_{\%}$ red is the half-wave reduction potential.

To compare, $\mathrm{C}_{60} / \mathrm{C}_{60}{ }^{-}$potential in $\mathrm{THF}$ is $-0.23 \mathrm{~V}$ vs. $\mathrm{Ag} / \mathrm{AgCl}^{4}$.

Table S-B.1. Optical, electrochemical and electronic properties of TAN and TAA derivatives

\begin{tabular}{|c|c|c|c|c|c|c|c|c|}
\hline Compounds & $\begin{array}{c}\lambda_{\text {abs }} \\
(\mathrm{nm})^{\mathrm{a}}\end{array}$ & $\mathrm{E}_{\mathrm{g}}^{\mathrm{opt}}(\mathrm{eV})^{\mathrm{b}}$ & $\mathrm{E}_{1 / 2}^{\mathrm{red}}(\mathrm{V})^{\mathrm{c}}$ & $\begin{array}{l}\text { LUMO } \\
(\mathrm{eV})^{\mathrm{d}}\end{array}$ & $\begin{array}{c}\text { HOMO } \\
(\mathrm{eV})^{\mathrm{e}}\end{array}$ & $\begin{array}{l}\text { LUMO }_{\text {calc }} \\
(\mathrm{eV})^{\mathrm{f}}\end{array}$ & $\begin{array}{c}\mathrm{HOMO}_{\text {calc }} \\
(\mathrm{eV})^{\mathrm{f}}\end{array}$ & $\begin{array}{c}\lambda_{\text {calc }} \\
(\mathrm{nm})^{\mathrm{g}}\end{array}$ \\
\hline TAN-Ph & $\begin{array}{l}232 \\
298\end{array}$ & 3.10 & -1.47 & -3.48 & -6.58 & -2.12 & -5.99 & 284 \\
\hline TAN-MePh & $\begin{array}{l}233 \\
297\end{array}$ & 3.05 & -1.49 & -3.46 & -6.51 & -2.10 & -5.88 & 284 \\
\hline TAA-Ph & $\begin{array}{l}278, \\
351\end{array}$ & 2.56 & -1.11 & -3.83 & -6.39 & -2.56 & -5.39 & 330 \\
\hline TAA-Tips & $\begin{array}{l}286, \\
371\end{array}$ & 2.38 & -0.80 & -4.15 & -6.53 & -2.86 & -5.44 & 357 \\
\hline TAA-OMePh & $\begin{array}{l}278, \\
354\end{array}$ & 2.53 & -1.15 & -3.80 & -6.33 & -2.56 & -5.39 & 330 \\
\hline TAA-tBuPh & $\begin{array}{l}279 \\
352\end{array}$ & 2.55 & -1.21 & -3.74 & -6.29 & -2.50 & -5.36 & 331 \\
\hline $\mathrm{TAA}-\mathrm{CF}_{3} \mathrm{Ph}$ & $\begin{array}{l}280 \\
353\end{array}$ & 2.56 & -0.88 & -4.07 & -6.63 & -2.76 & -5.55 & 334 \\
\hline
\end{tabular}

a: Two main absorption features for each compound. b: Optical bandgap calculated from the threshold of UV-vis absorption spectrum. c: Halfwave reduction potential vs $\mathrm{Ag} / \mathrm{AgCl}$. d: LUMO energy level calculated from $\mathrm{E}_{1}{ }_{2}^{\text {red }}$ using equation 1 . e: HOMO energy level estimated from LUMO energy and optical bandgap values. f: HOMO and LUMO energy level calculated at the B3LYP/6-31G(d) level in THF. g: Maximum absorption wavelength calculated at the CAM-B3LYP/6-311G(d) level in DCM.
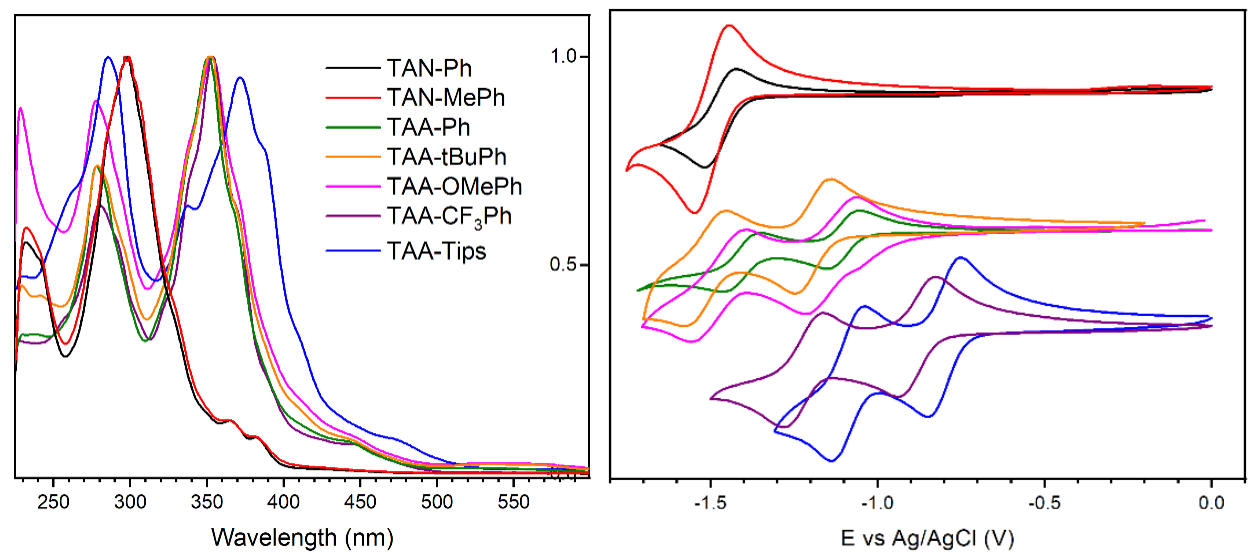

Figure S-B.1. Normalized UV-vis spectra in DCM (top) and cyclic voltam-mograms in THF (bottom) of TANs and TAAs. Cyclic voltammograms were recorded at $0.1 \mathrm{~V} / \mathrm{s}$ in $1 \mathrm{mM}$ THF solution $(0.25 \mathrm{M} \mathrm{Bu} 4 \mathrm{NPF} 6$, glassy carbon as working electrode, $\mathrm{Ag} / \mathrm{AgCl}$ as reference electrode) 


\section{Thermal properties}

Thermogravimetric (TG) and differential scanning calorimetry (DSC) analyses were performed by using a STA 449 F5 Jupiter Simultaneous Thermal Analyzer (TG-DTG, DTA, DSC) from NETZSCH under an argon flow at a heating rate of $20 \mathrm{~K} \cdot \mathrm{min}^{-1}$. The point of $5 \%$ weight loss was used to determine the temperature of thermal decomposition (Td). The different thermograms are depicted in Figure S-C.1.
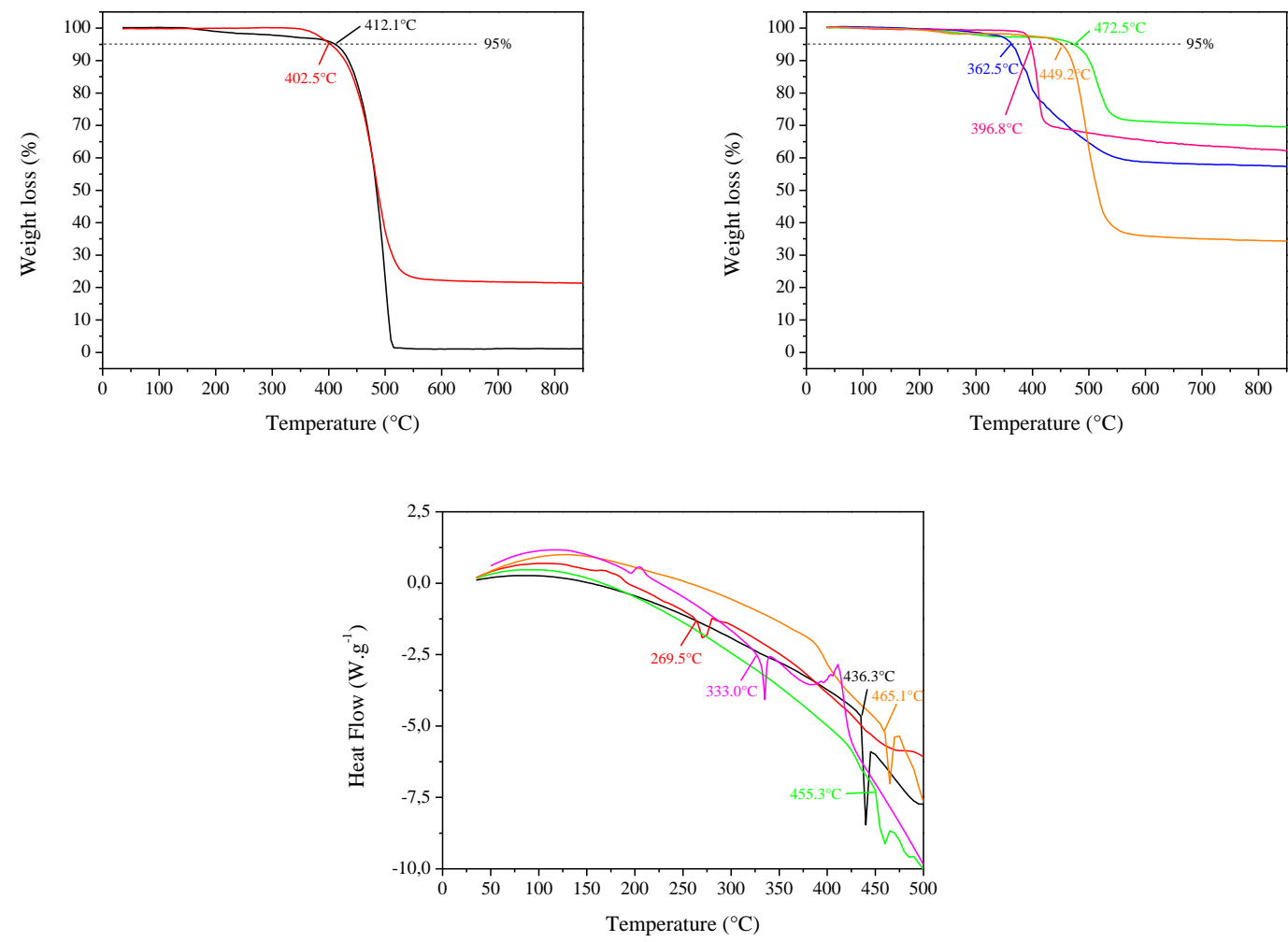

Figure S-C.1. TGA (A,B) and DSC (C ) curves for TAN-Ph (black), TAN-MePh (red), TAA-Ph (green), TAA-Tips (blue), TAA-OMePh (pink) and TAA-tBuPh (Orange).

TAN-Ph and TAN-MePh showed high thermal stability with decomposition temperature (Td) of $412^{\circ} \mathrm{C}$ and $402^{\circ} \mathrm{C}$, respectively, the decomposition process occurring in a steep single stage. Moreover, TAA-Ph and TAA-tBuPh appeared to be even more thermally stable with decomposition temperature of $449^{\circ} \mathrm{C}$ and $472^{\circ} \mathrm{C}$, respectively, and, once again, through a steep single decomposition stage. This suggests that the introduction of azaanthrylene arms has a beneficial effect on the thermal stability. Nonetheless, the nature of the branches also strongly affects the thermal stability. Thus TAA-OMePh and TAA-Tips are much less stable, with decomposition temperature of $397^{\circ} \mathrm{C}$ and $362^{\circ} \mathrm{C}$, respectively, and a decomposition pathway involving at least two different steps in the last case.

On the other hand, DSC curves of TAA-OMePh and TAA-Tips exhibited no feature of any phase transition before the decomposition stage. By contrast, the DSC traces of TAN-MePh and TAA-OMePh showed an endothermic feature at

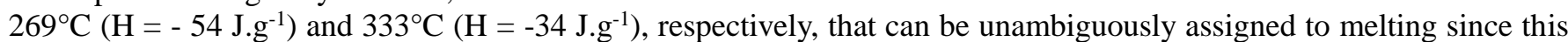
temperature is far below the decomposition temperature. Similar features were also found for TAN-Ph, TAA-Ph and TAA$\mathrm{tBuPh}$ at $436^{\circ} \mathrm{C}\left(\mathrm{H}=-92 \mathrm{~J}^{-1}\right), 455^{\circ} \mathrm{C}\left(\mathrm{H}=-44 \mathrm{~J}^{-1}\right)$ and $465^{\circ} \mathrm{C}\left(\mathrm{H}=-86 \mathrm{~J}^{-1} \mathrm{~g}^{-1}\right)$ indicating that melting took place just before the decomposition process. 


\section{Crystallographic data}

Single crystals of all the compounds were obtained by solution diffusion method using dichloromethane and methanol as solvents. Crystallographic data were acquired at CESAMO (ISM, UMR 5255 CNRS) on a Bruker APEX 2 DUO. A single crystal was mounted and immersed in a stream of nitrogen gas $[T=150(2) \mathrm{K}]$. Data were collected, using a microfocus sealed tube of Mo Ka radiation $(k=0.71073 \AA)$ on a KappaCCD diffractometer. Data collection and cell refinement were performed using APEX2 2013.10-0 (Bruker AXS Inc.), and SAINT v8.34A (Bruker AXS Inc.). Data reduction was performed using SAINT v8.34A (Bruker AXS Inc.). Correction for absorption was performed using multi-scan integration as included in SADABS V2012/1 (Bruker AXS). Structure solutions were found by charge flipping methods (SUPERFLIP (Palatinus \& Chapuis, 2007) EDMA (Palatinus et al., 2012)) and refined with (SHELXL) (G.M. Sheldrick, A short history of SHELX, Acta Crystallographica Section A, 64 (2008), pp. 112-122). Crystallographic data of all the compounds are presented in table S-D.1. and table S-D.2.

Table S-D.1. Crystallographic parameters for TAN-Ph, TAN-MePh and TAA-Ph.

\begin{tabular}{|l|l|l|l|}
\hline & \multicolumn{1}{|c|}{ TAN-Ph } & \multicolumn{1}{c|}{ TAN-MePh } & \multicolumn{1}{c|}{ TAA-Ph } \\
\hline Chemical formula & $\mathrm{C}_{45} \mathrm{H}_{27} \mathrm{~N}_{3}$ & $\mathrm{C}_{48} \mathrm{H}_{33} \mathrm{~N}_{3}$ & $\mathrm{C}_{38} \mathrm{H}_{22} \mathrm{~N}_{2}$ \\
\hline Formula weight & 609.69 & 651.77 & 506.57 \\
\hline Crystal system & Triclinic & Triclinic & Trigonal \\
\hline Space group & $\mathrm{P}-1$ & $\mathrm{P}-1$ & $\mathrm{R} 3: \mathrm{H}$ \\
\hline$a / \AA$ & $11.4220(5)$ & $11.2751(10)$ & $26.890(2)$ \\
\hline$b / \AA$ & $11.8638(6)$ & $12.3505(11)$ & $26.890(2)$ \\
\hline$c / \AA$ & $13.6400(7)$ & $13.4070(12)$ & $9.3703(8)$ \\
\hline$\alpha /^{\text {o }}$ & $115.445(2)$ & $99.461(3)$ & 90 \\
\hline$\beta /^{\mathbf{o}}$ & $98.835(2)$ & $92.650(3)$ & 90 \\
\hline$\gamma /^{\text {o }}$ & $107.484(2)$ & $108.041(3)$ & 120 \\
\hline $\mathrm{V} / \AA^{3}$ & $1503.75(13)$ & $1741.6(3)$ & $5867.6(10)$ \\
\hline $\mathrm{Z}$ & 2 & 2 & 9 \\
\hline$D$ calc $/ \mathrm{mg}^{-3}$ & 1.347 & 1.243 & 1.290 \\
\hline Temperature / K & 120 & 120 & 120 \\
\hline No. of reflections measured & 46762 & 44512 & 11458 \\
\hline No. of independent reflections & 5703 & 8436 & 5457 \\
\hline Residuals: R & 0.0406 & 0.0486 & 0.0559 \\
\hline Residuals: wR & 0.1159 & 0.0995 \\
\hline Goodness of fit indicator & 1.009 & 1.026 & 1.006 \\
\hline
\end{tabular}


Table S-D.2. Crystallographic parameters for TAA-Tips, TAA-OMe-Ph and TAA-tBuPh.

\begin{tabular}{|l|l|l|l|}
\hline & \multicolumn{1}{|c|}{ TAA-Tips } & \multicolumn{1}{c|}{ TAA-OMePh } & \multicolumn{1}{c|}{ TAA-tBuPh } \\
\hline Chemical formula & $\mathrm{C}_{73} \mathrm{H}_{83} \mathrm{Cl}_{2} \mathrm{~N}_{3} \mathrm{Si}_{3}$ & $\mathrm{C}_{66} \mathrm{H}_{51} \mathrm{~N}_{3} \mathrm{O}_{9}$ & $\mathrm{C}_{81} \mathrm{H}_{81} \mathrm{~N}_{3}$ \\
\hline Formula weight & 1157.59 & 1030.09 & 1096.48 \\
\hline Crystal system & Monoclinic & Triclinic & Triclinic \\
\hline Space group & $\mathrm{P} 21 / \mathrm{n}$ & $\mathrm{P}-1$ & $\mathrm{P}-1$ \\
\hline$a / \AA$ & $18.2212(10)$ & $11.2358(6)$ & $14.2405(16)$ \\
\hline$b / \AA$ & $10.4445(5)$ & $15.7124(9)$ & $17.0268(18)$ \\
\hline$c / \AA$ & $33.2572(19)$ & $16.9610(10)$ & $17.130(2)$ \\
\hline$\alpha /^{\text {o }}$ & 90 & $68.562(2)$ & $118.098(3)$ \\
\hline$\beta /^{\text {o }}$ & $91.409(2)$ & $84.545(2)$ & $99.825(4)$ \\
\hline$\gamma /^{\text {o }}$ & 90 & $75.900(2)$ & $99.093(3)$ \\
\hline $\mathrm{V} / \AA^{3}$ & $6327.3(6)$ & $2703.1(3)$ & $3471.8(7)$ \\
\hline $\mathrm{Z}$ & 4 & 2 & 2 \\
\hline Dcalc /mg $\mathrm{m}^{-3}$ & 1.215 & 1.266 & 1.049 \\
\hline Temperature / K & 120 & 120 & 120 \\
\hline No. of reflections measured & 98701 & 89514 & 101981 \\
\hline No. of independent reflections & 13996 & 12760 & 13903 \\
\hline Residuals: R & 0.0649 & 0.0496 & 0.0942 \\
\hline Residuals: wR & 0.1164 & 0.2703 \\
\hline Goodness of fit indicator & 1.055 & 1.009 & 1.022 \\
\hline
\end{tabular}




\section{Geometrical parameters for each individual molecules}

All molecular structures exhibit twists and bendings in single crystals. Bending and twisting angles are summarized in table S-D.3.

Table S-D.3. Molecular structural parameters deduced from XRD.

\begin{tabular}{|c|c|c|c|c|}
\hline & Twist angle $\left({ }^{\circ}\right)^{\mathrm{a}}$ & Distance $(\AA)^{b}$ & Bending angle $\left({ }^{\circ}\right)^{c}$ & Bending radius $(\AA)^{d}$ \\
\hline TAN-Ph & $19,11,4$ & $0.73,0.3,0.28$ & $-8.7,3.5,3.3$ & $16,40,42$ \\
\hline TAN-MePh & $24,8,8$ & $0.73,0.65,0.02$ & $-8.7,7.7,0.2$ & $16,18,821$ \\
\hline TAA-Ph & $\begin{array}{l}13,13,13 \\
11,11,11 \\
\end{array}$ & $\begin{array}{l}0.12,0.12,0.12 \\
0.27,0.27,0.27\end{array}$ & $\begin{array}{l}1.4,1.4,1.4 \\
3.2,3.2,3.2 \\
\end{array}$ & $\begin{array}{l}101,101,101 \\
43,43,43\end{array}$ \\
\hline TAA-Tips & $13,13,10$ & $0.48,0.39,0.17$ & $-5.7,4.6,2.0$ & $24,30,70$ \\
\hline TAA-OMePh & $27,25,3$ & $0.87,0.32,0.32$ & $-10.3,3.8,3.8$ & $14,36,36$ \\
\hline TAA-tBuPh & $5,3,3$ & $0.2,0.17,0.07$ & $2.4,2.0,0.8$ & $57,70,180$ \\
\hline TAA-CF ${ }_{3} \mathrm{Ph}$ & I & / & / & I \\
\hline
\end{tabular}

a: Twist angles between the mean plane of the central ring and the mean plane of each branch; b: distances from the centroid of the third phenyl ring and the mean plane of central ring; c: Bending angles between the mean plane of the central ring and the line connecting the centroids of third and central phenyl rings. d: Bending radius $(\AA)$ calculated as the radius of circle connecting the centroid of the first and third ring and tangent to the mean plane of the first ring.

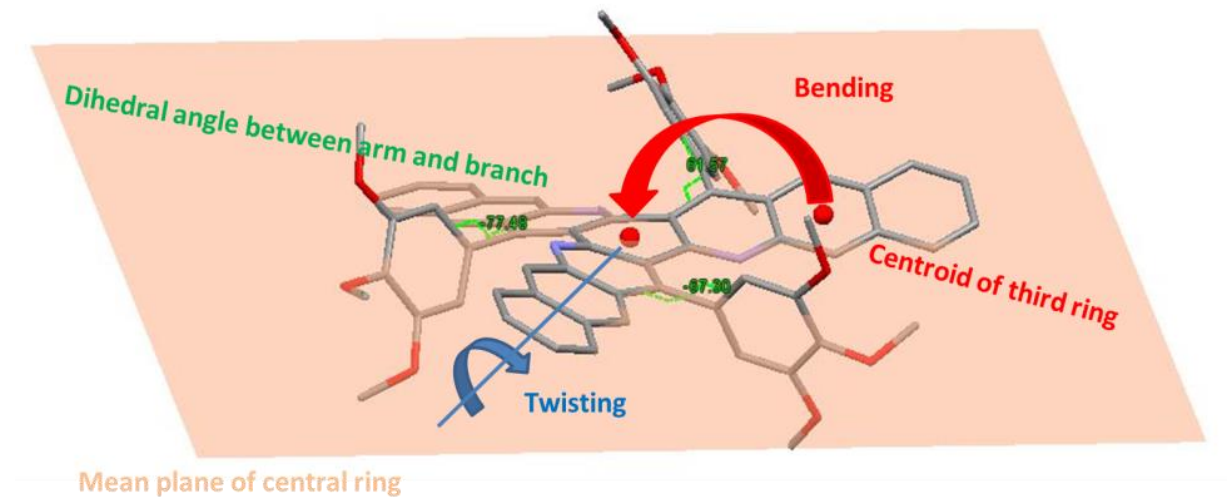

Figure S-D.1. Graphical representation of geometrical parameters for a single molecule listed in Table S-D.3. 


\section{Molecules and their closer neighbors in packing}

Figures showing the molecular packing in single crystals are reported below. Only one geometrical conformation exists for TAN-Ph, TAN-MePh, TAA-Tips, TAA-OMePh and TAA-tBuPh. The reference molecule is dark red colored. Intermolecular contacts between this molecule and its first neighbors are shown in light blue. Molecule TAA-Ph exhibits two different conformations in the single crystal, colored in red and blue in the Figures below.

Close contacts between carbon atoms belonging to neighboring molecules were determined using the following criteria: a distance threshold of $2 * \mathrm{VdW}$ radius $+0.2 \AA$ was applied for TAN-Ph, TAN-MePh, TAA-Tips and TAA-tBuPh, and of $2 * \mathrm{VdW}$ radius $+0.3 \AA$ for TAA-Ph and TAA-OMePh. The color code is defined as follows: pink molecules can be deduced from the reference molecule (in red) by a translation operation. Molecules in light green are deduced from the reference one by an inversion operation. In TAA-Ph, two non-equivalent geometries are shown in red and blue for reference molecules. Then, light blue molecules correspond to the blue one after a translation operation. In all Figures, lateral substituents (branches) and hydrogen atoms have been hidden for clarity, as well as contacts from these atoms. For each compound, crystalline packing is shown normal to the three lattice planes $a b, b c$ and $a c$.

\section{TAN-Ph}

Description: two arms of the reference molecule are connected via extended $\square \pi$-stacking with two arms of two inversed molecules, suggesting one efficient charge transport pathway in the $\square \pi$-stacking direction.
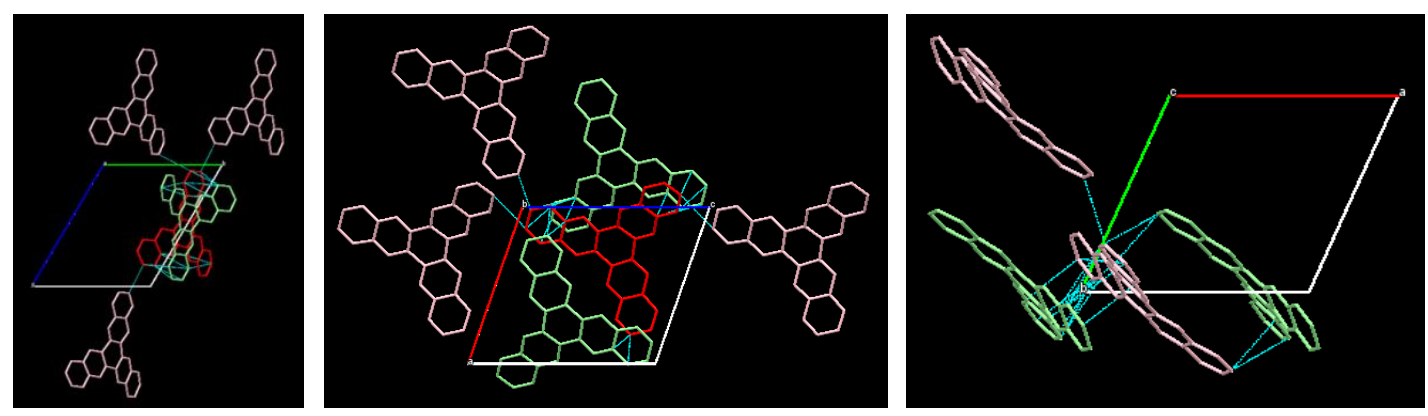

Figure S-D.2. Following three planes (100), (010) and (001), a molecule in red is represented with their closer neighbors (Symmetry operation are an inversion with the light green neighbors and identity with the light red neighbors). Blue lines correspond to C-C contacts with a distance smaller than $3.6 \AA$.

\section{TAN-MePh}

Description: two arms of the reference are connected via extended $\square \pi$-stacking with two arms of two inversed molecules, suggesting one efficient charge transport pathway in the $\square \pi$-stacking direction.
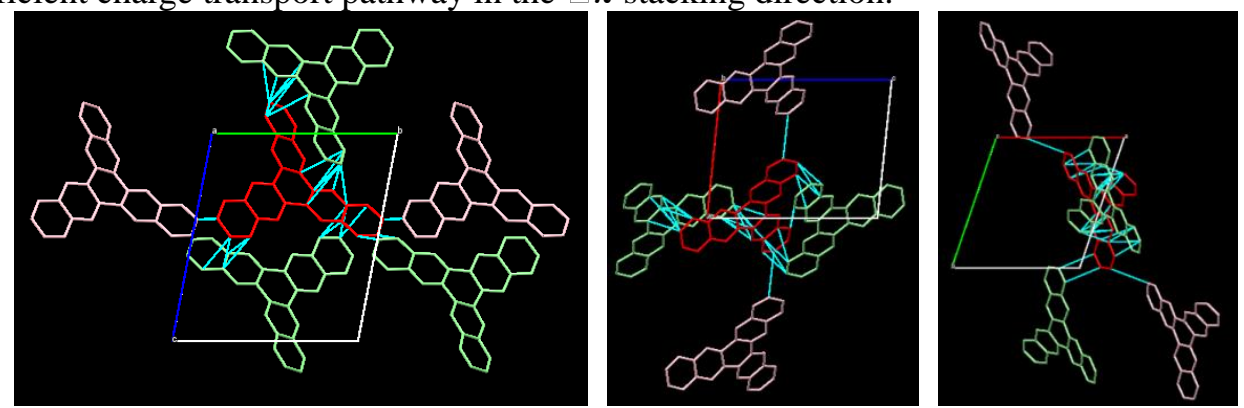

Figure S-D.3. Following three planes (100), (010) and (001), a molecule in red is represented with their closer neighbors (Symmetry operation are an inversion with the light green neighbors and identity with the light red neighbors). Blue lines correspond to C-C contacts with a distance smaller than $3.6 \AA$. 


\section{TAA-Ph}

Arms of the two reference non-equivalent molecules (red and blue) are connected via small $\square \pi$ - $\pi$ stacking with neighbouring molecules in all directions, suggesting several but not particularly efficient charge transport pathway.

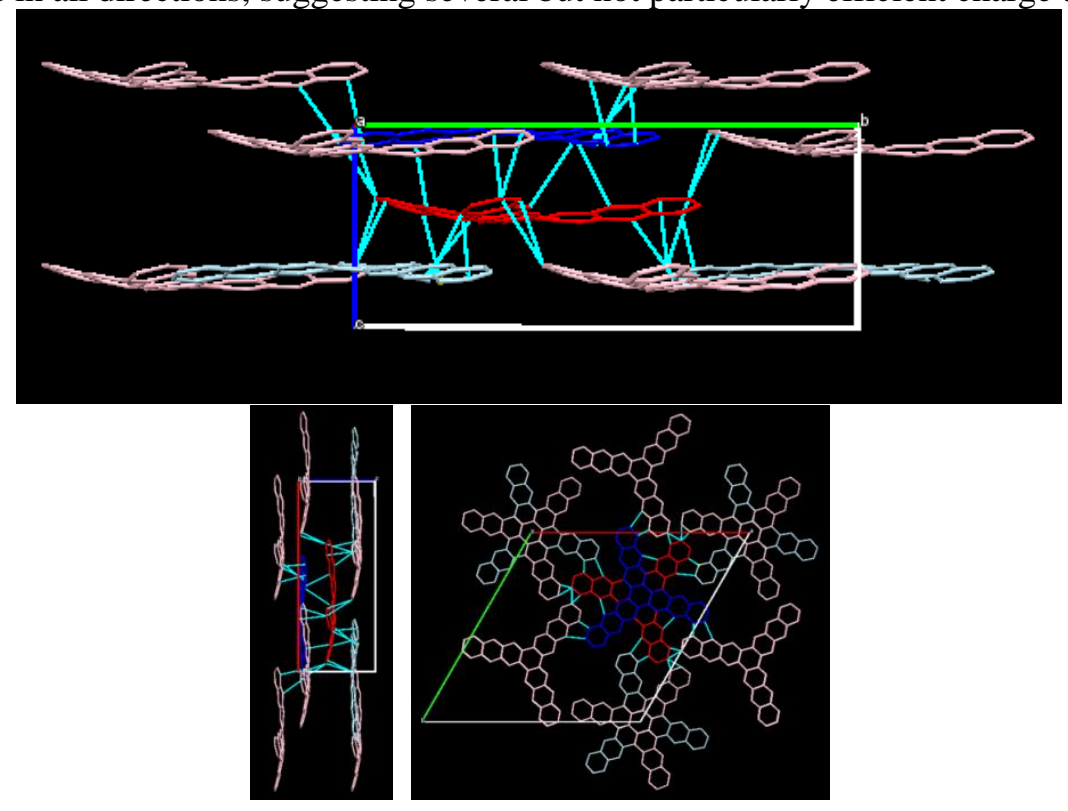

Figure S-D.4. Following three planes (100), (010) and (001), two molecules with geometry called A and B are collored in red and blue respectivly. Their closer neighbors are represented (neighbors in light red and in light blue follow the $\mathrm{A}$ and B geometry,respectivly). Blue lines correspond to C-C contacts with a distance smaller than $3.7 \AA$.

\section{TAA-Tips}

One arm of one molecule is connected via extended $\pi-\pi$ stacking with one arm of two inversed molecules, suggesting one efficient charge transport pathway in the $\pi$-stacking direction.
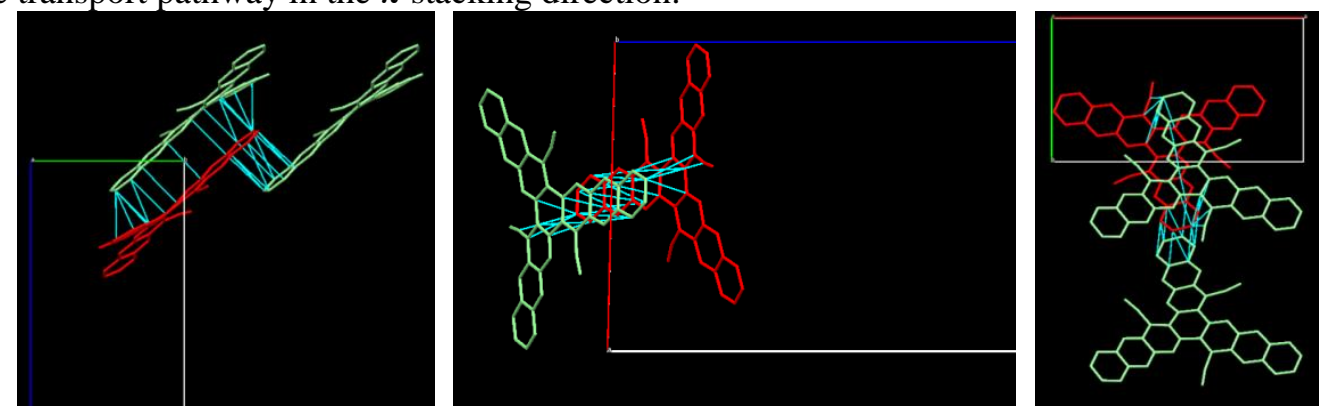

Figure S-D.5. Following three planes (100), (010) and (001), a molecule in red is represented with their closer neighbors

(Symmetry operation are an inversion with the light green neighbors). Blue lines correspond to $\mathrm{C}$-C contacts with a distance smaller than $3.6 \AA$. 


\section{TAA-OMePh}

One arm of one molecule is connected via extended $\pi-\pi$ stacking with one arm of three inversed molecules; suggesting $2 \mathrm{D}$ charge transport pathway within molecular layers.
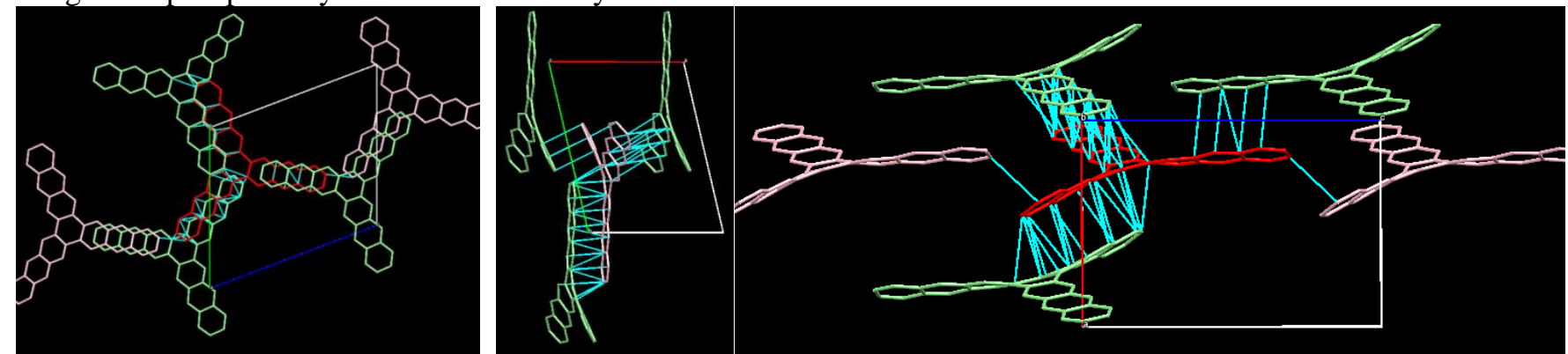

Figure S-D.6.: Following three planes (100), (010) and (001), a molecule in red is represented with their closer neighbors (Symmetry operation are an inversion with the light green neighbors and identity with the light red neighbors).

Blue lines correspond to C-C contacts with a distance smaller than $3.7 \AA$.

\section{TAA-tBuPh}

No $\pi-\pi$ interactions between molecules, suggesting no charge transport.
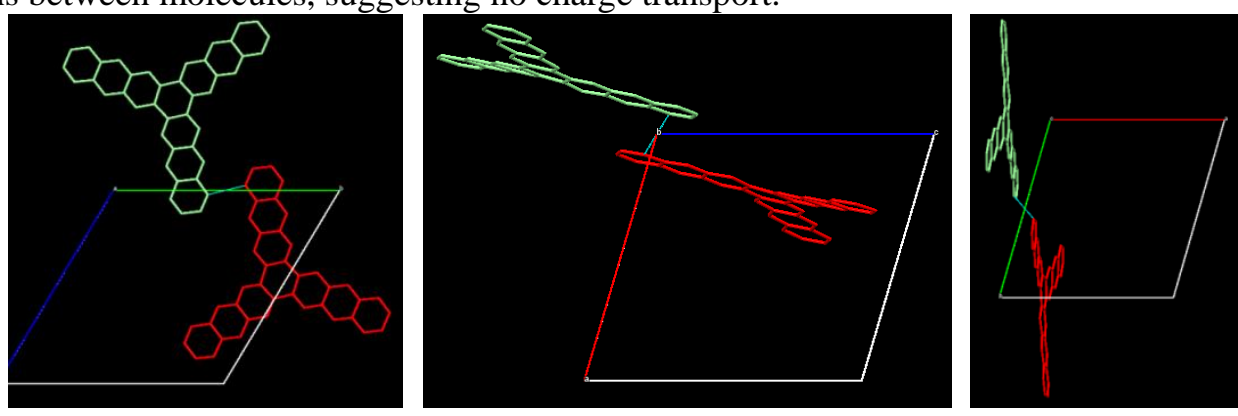

Figure S-D.7. Following three planes (100), (010) and (001), a molecule in red is represented with their closer neighbors

(Symmetry operation are an inversion with the light green neighbors). Blue lines correspond to $\mathrm{C}$ - $\mathrm{C}$ contacts with a distance smaller than $3.6 \AA$. 


\section{Thermal ellipsoid plot}

Figures showing the atomic displacements in each chemical structures are reported below. The ellipsoid contour probability has been set at $20 \%$.

\section{TAN-Ph}

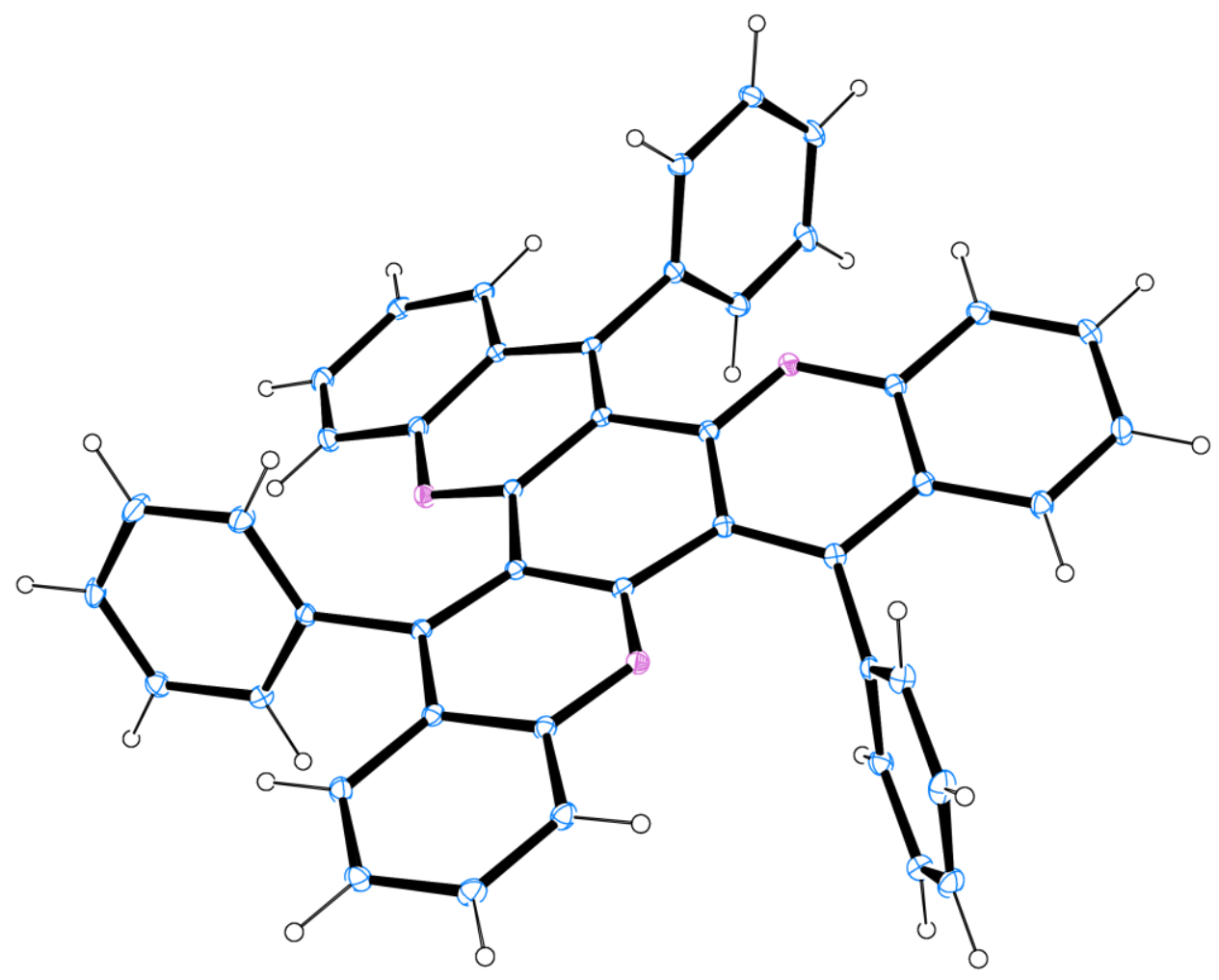


TAN-MePh

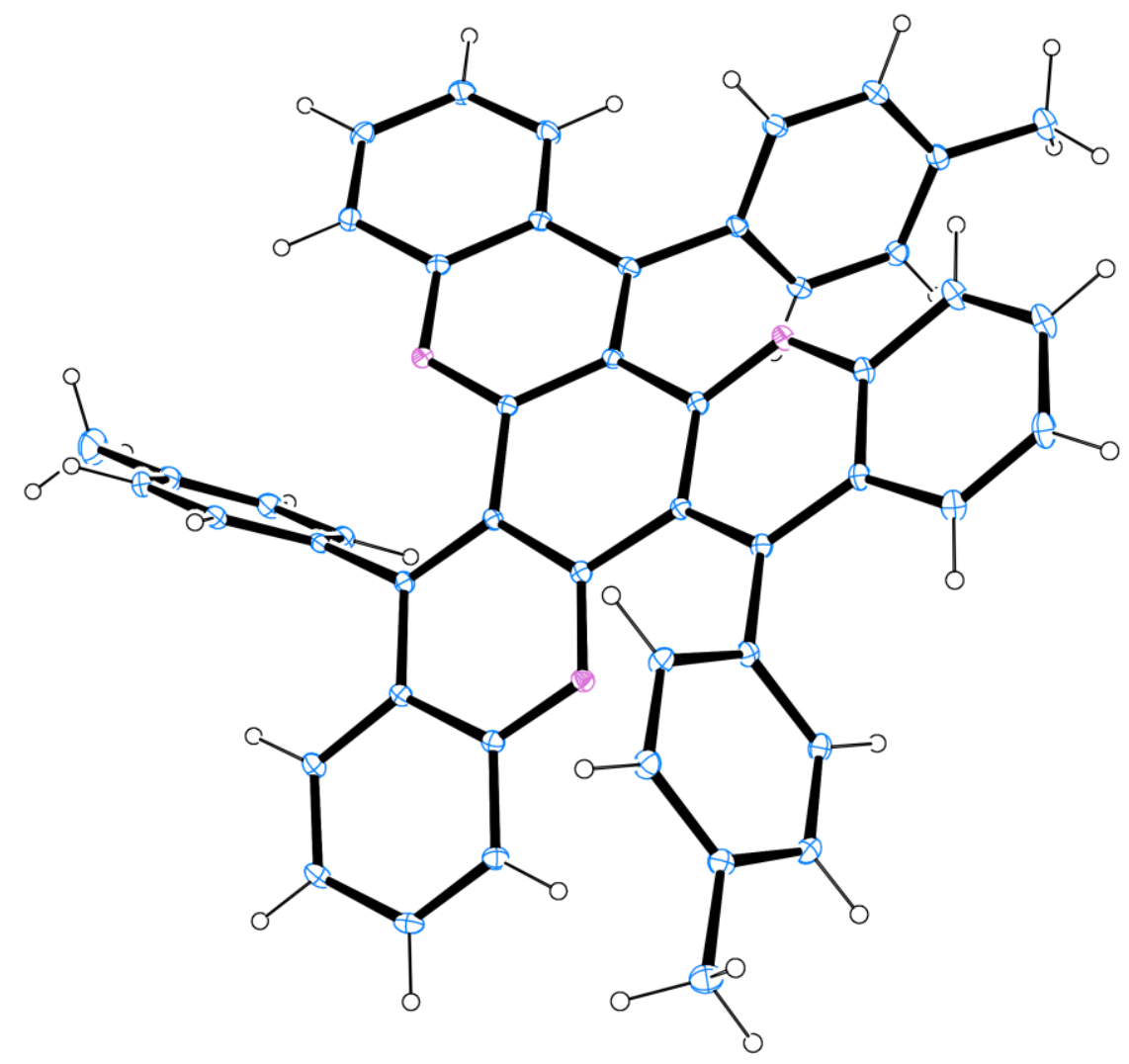




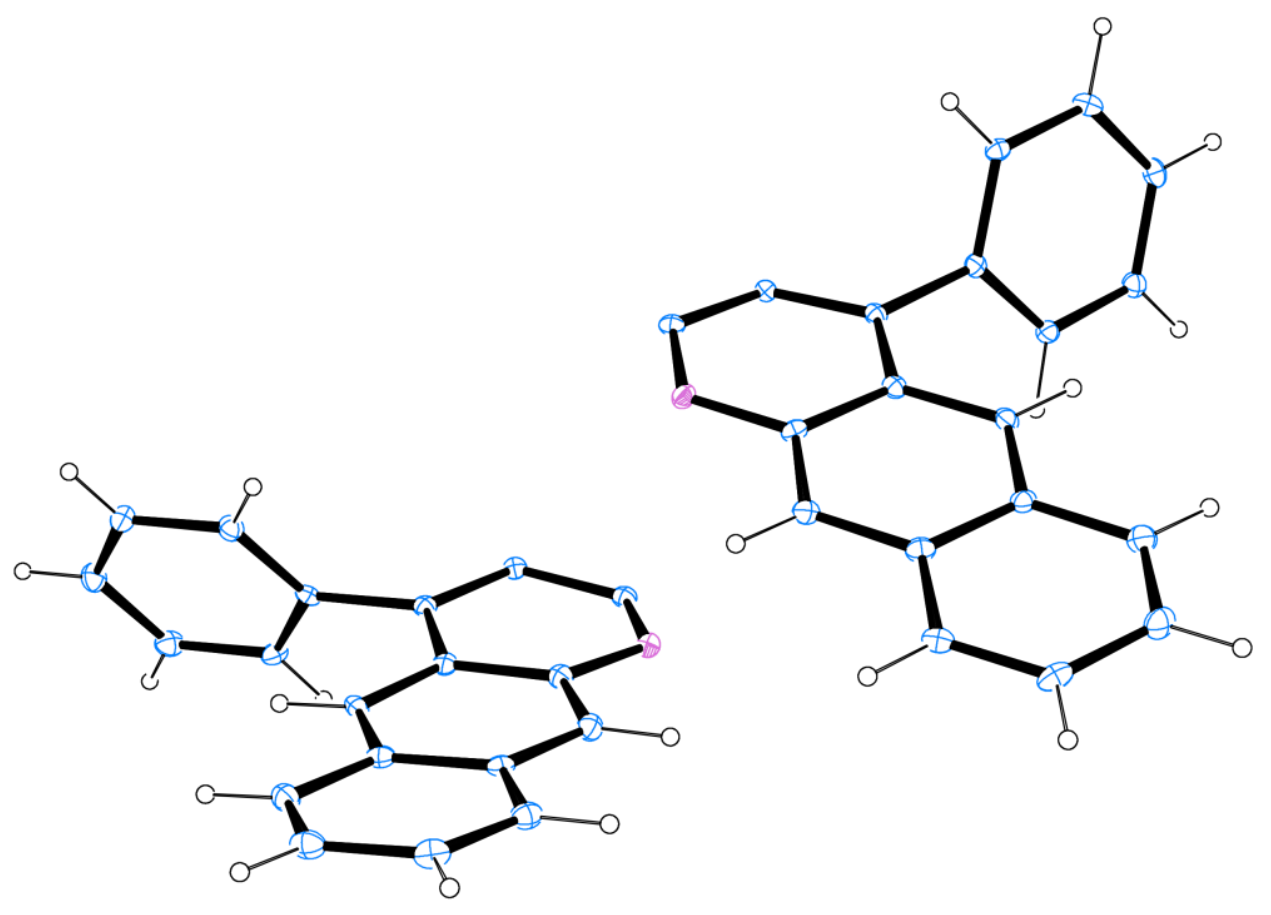


2

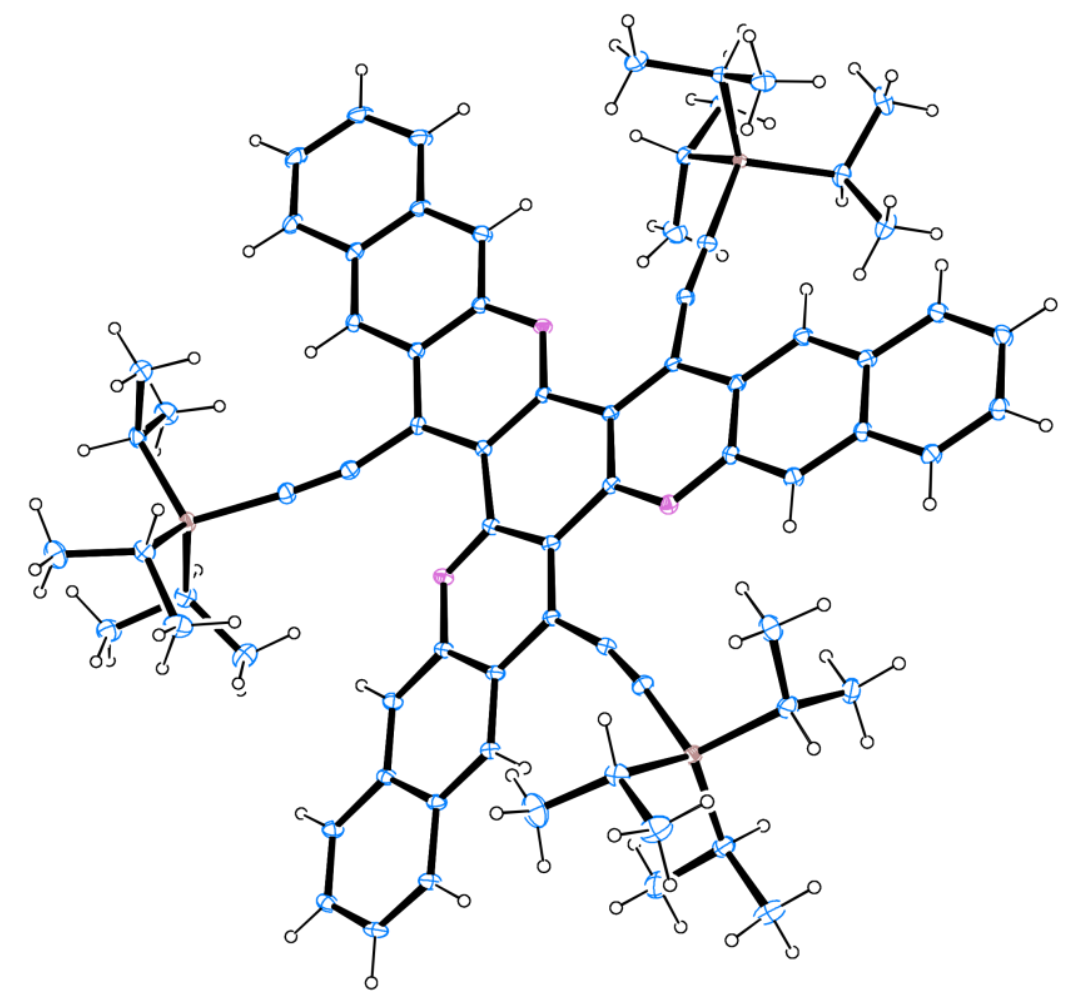




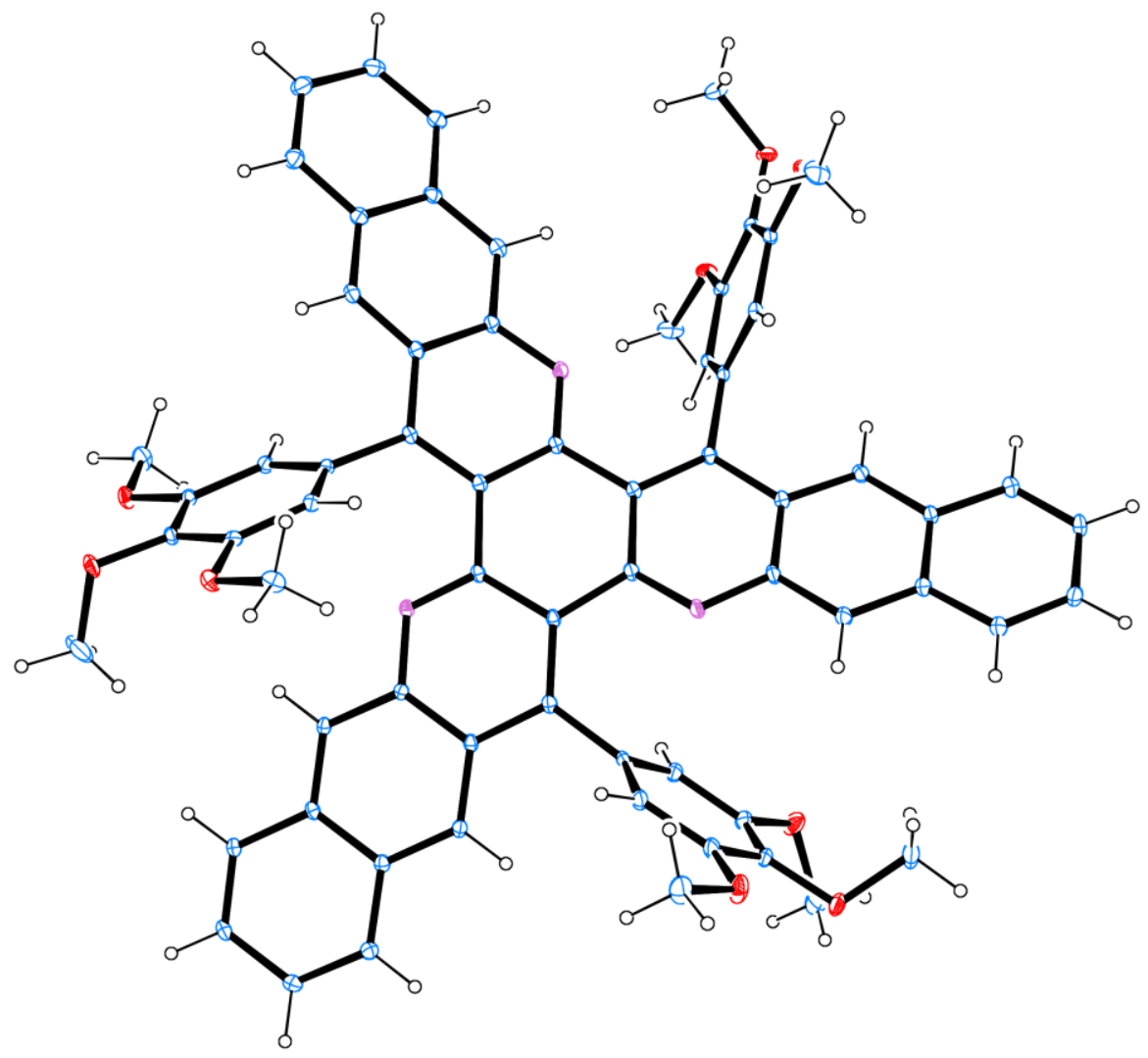


TAA-tBuPh

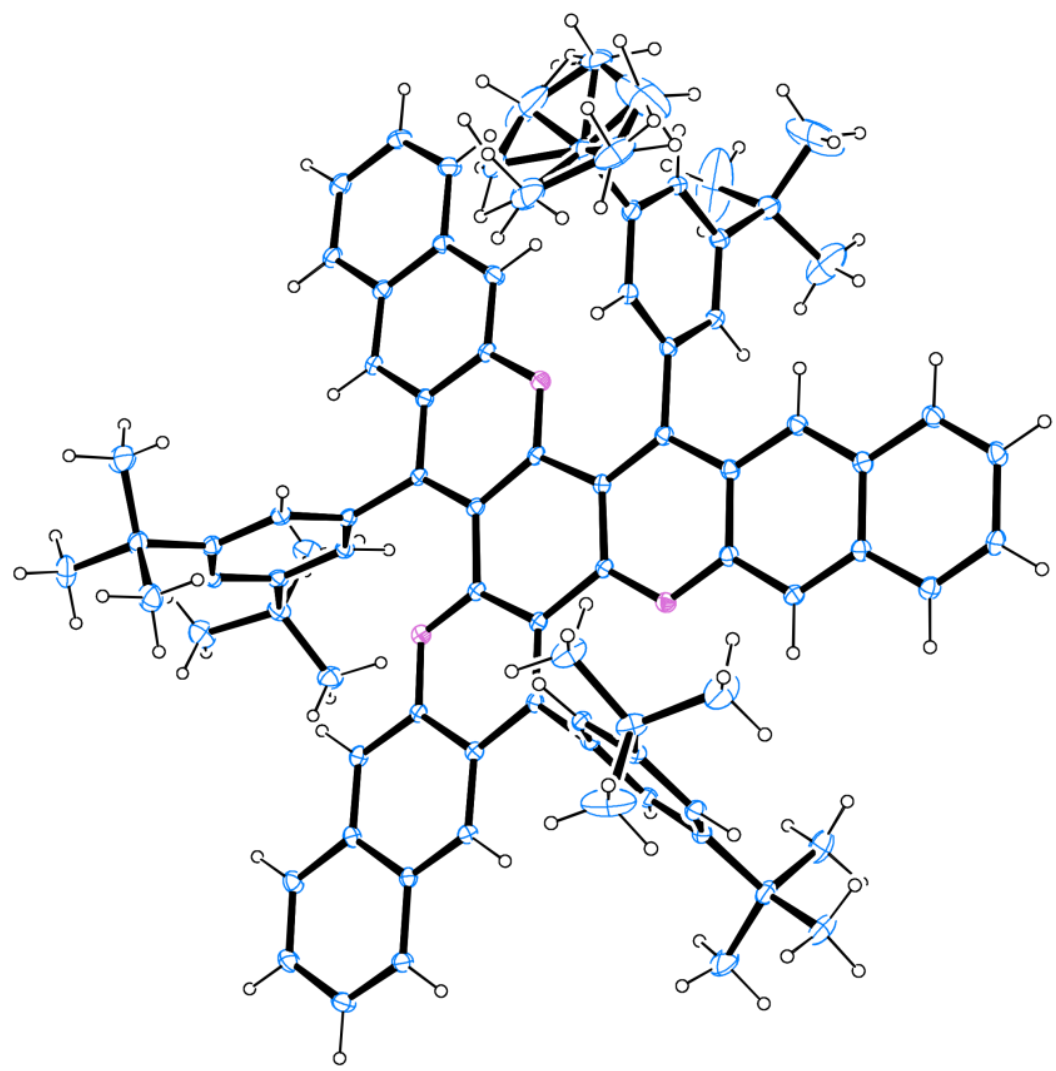




\section{Representation of packing with whole molecular structure}

Figures below show the complete molecular structures of all molecules whom any atom is included in a unit cell.

TAN-Ph
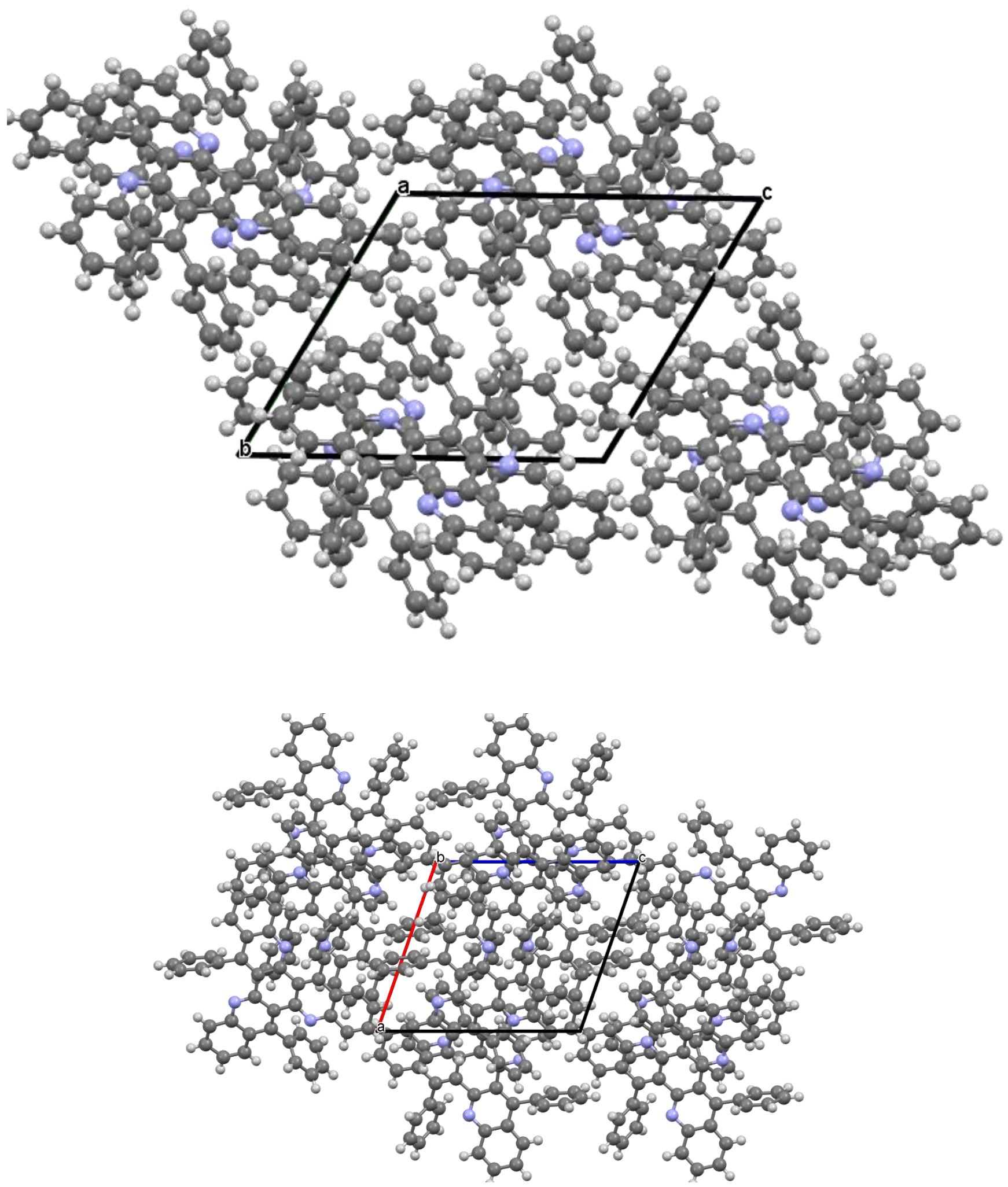


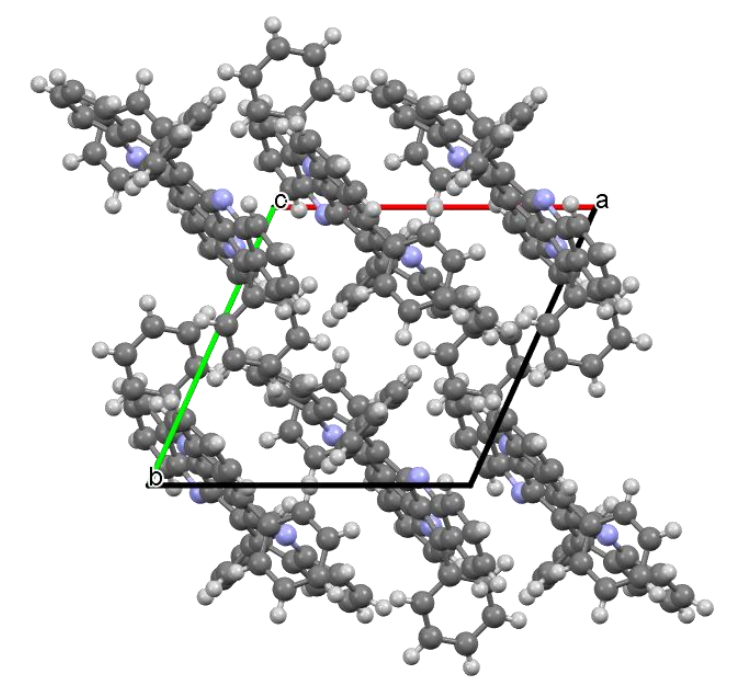

Figure S-D.2. Following three planes (100), (010) and (001).

TAN-MePh

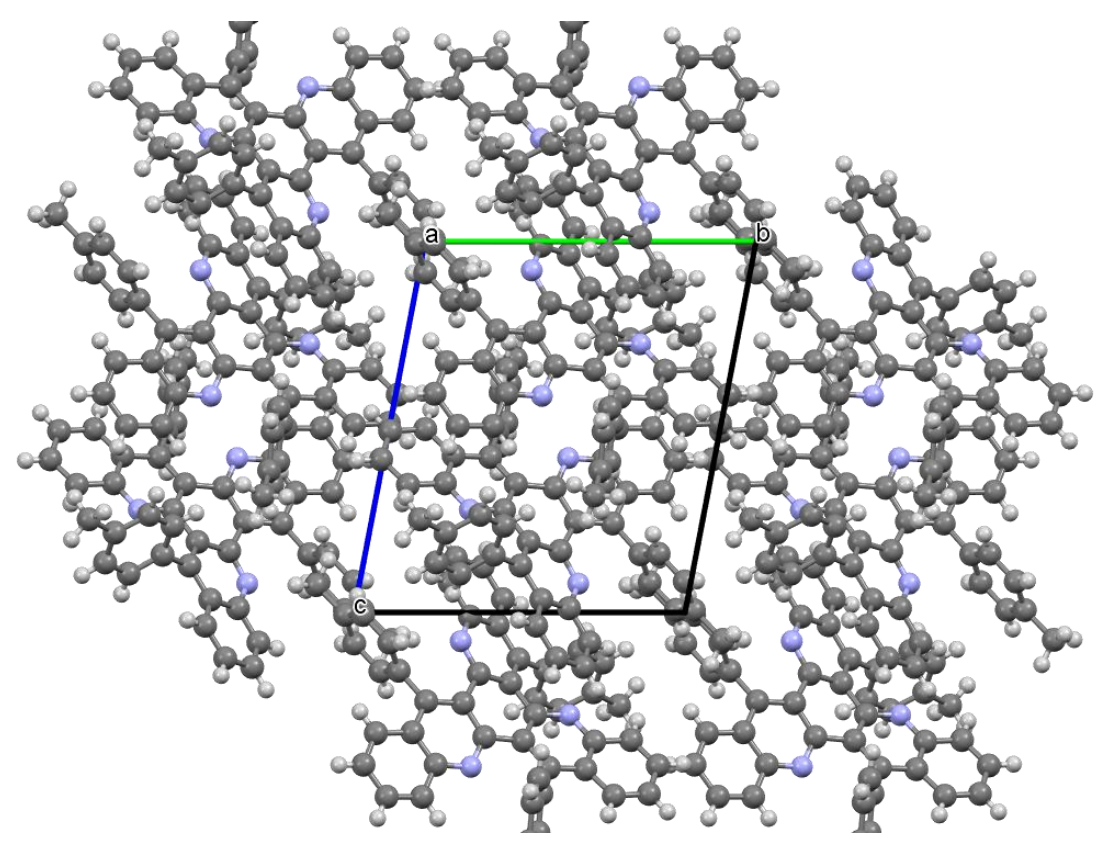




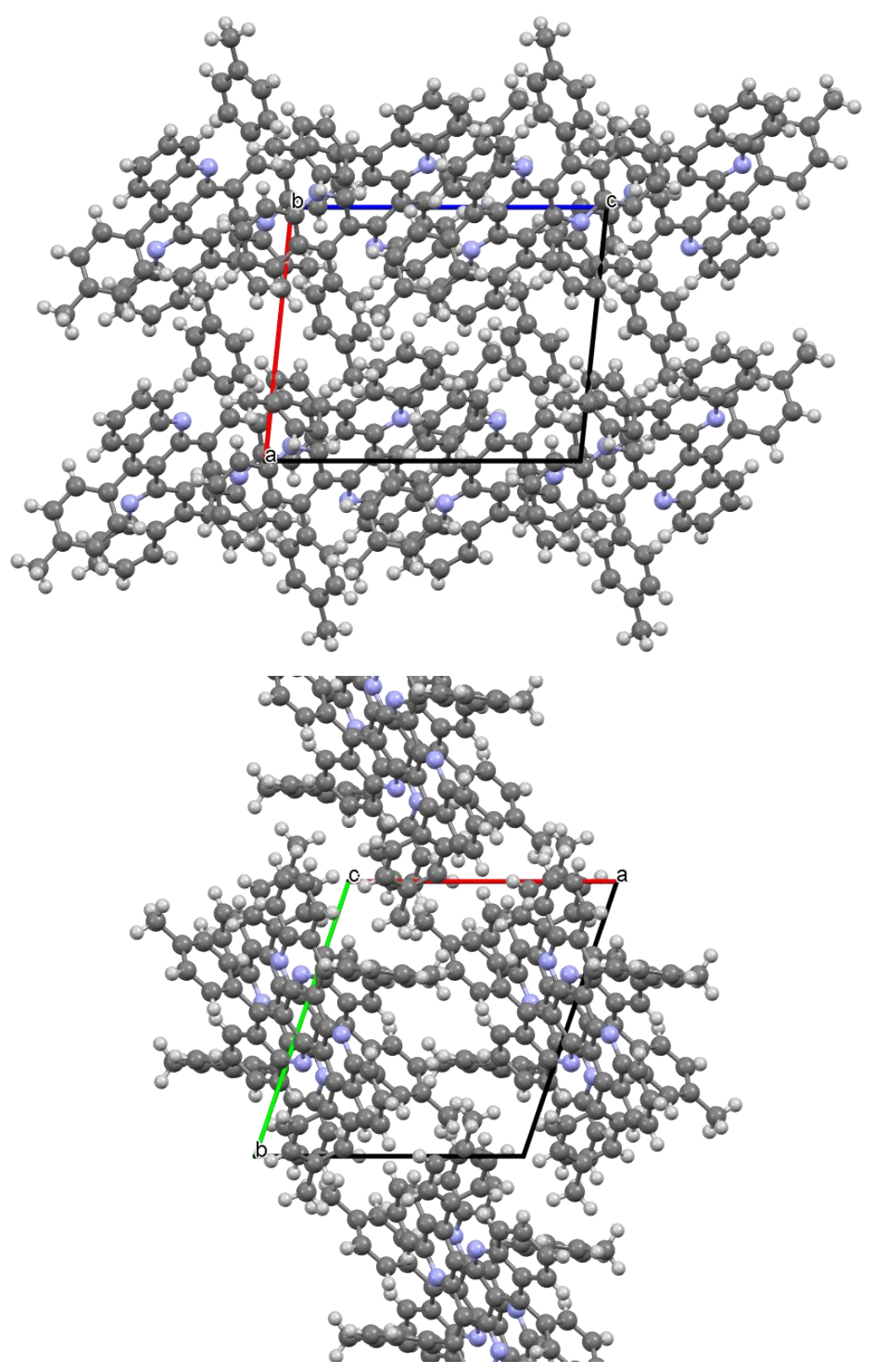

Figure S-D.3. Following three planes (100), (010) and (001). 

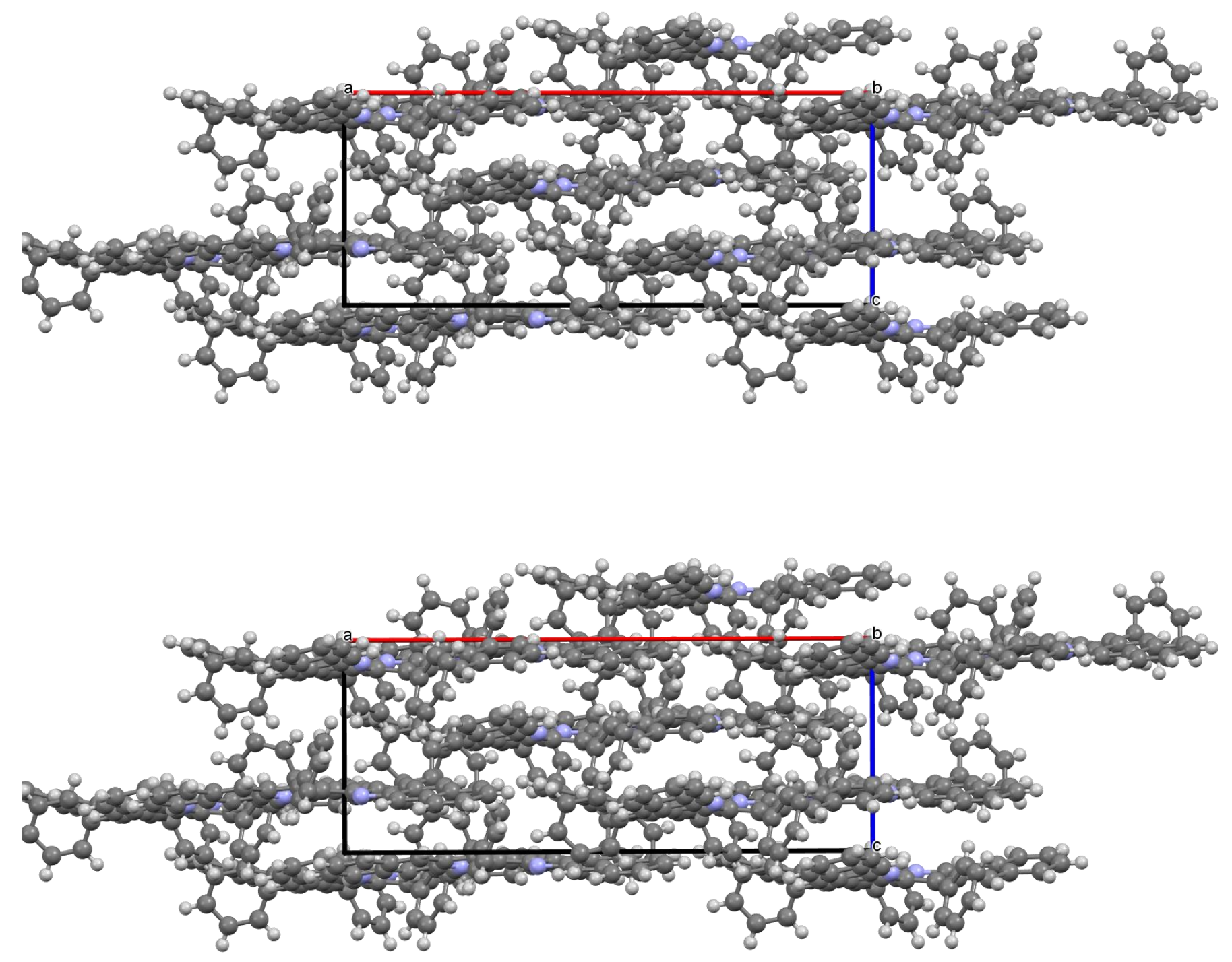


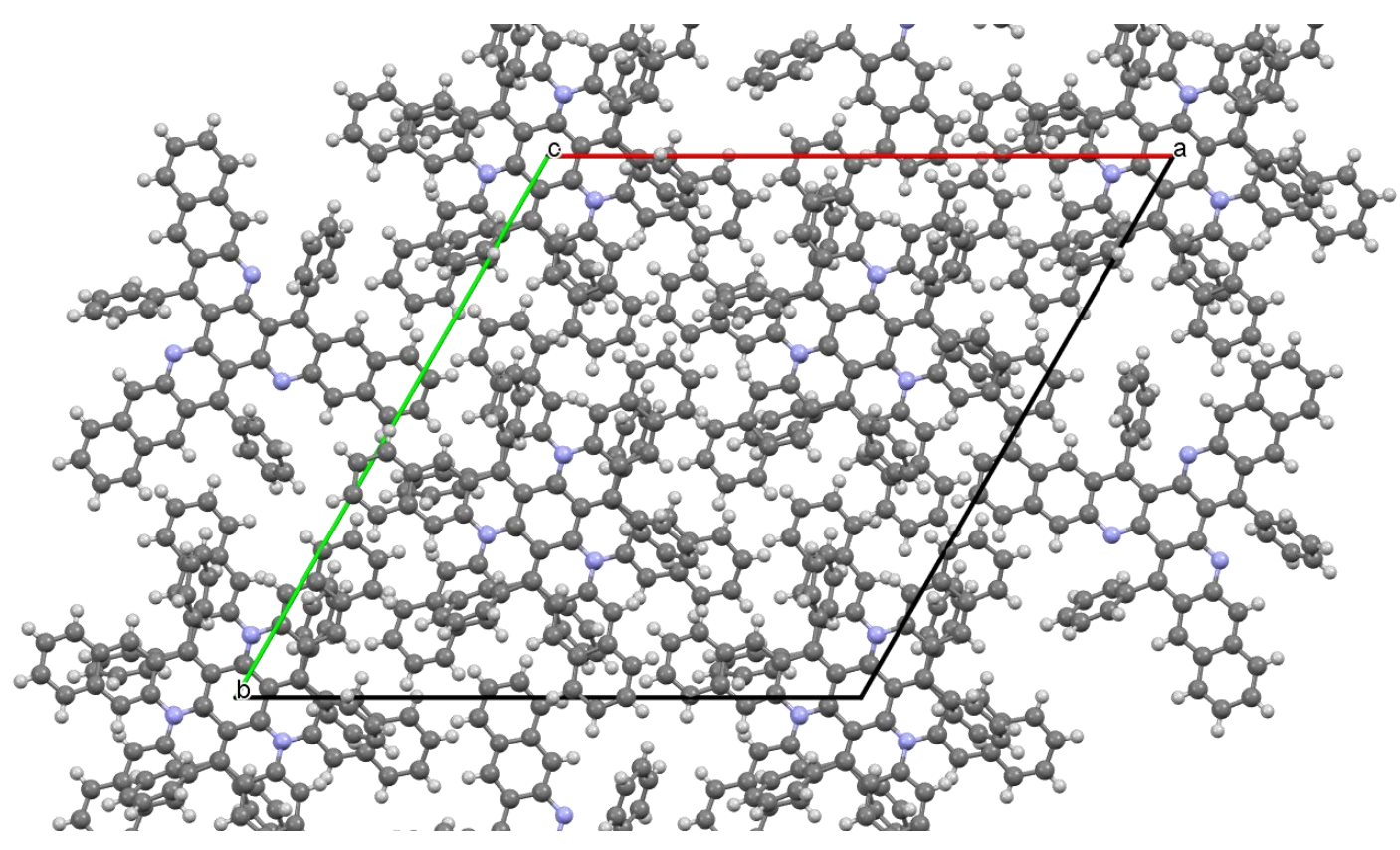

Figure S-D.4. Following three planes (100), (010) and (001).

TAA-Tips

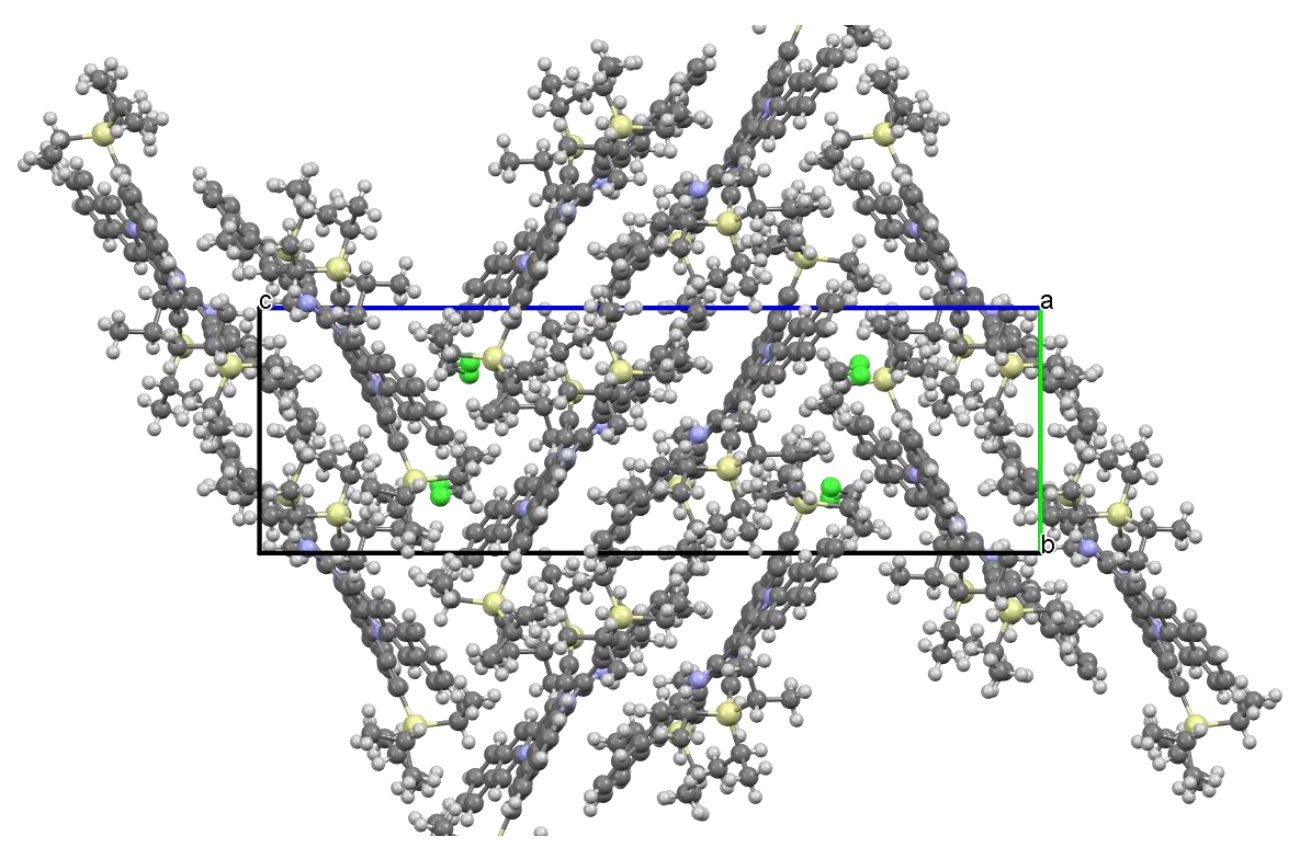




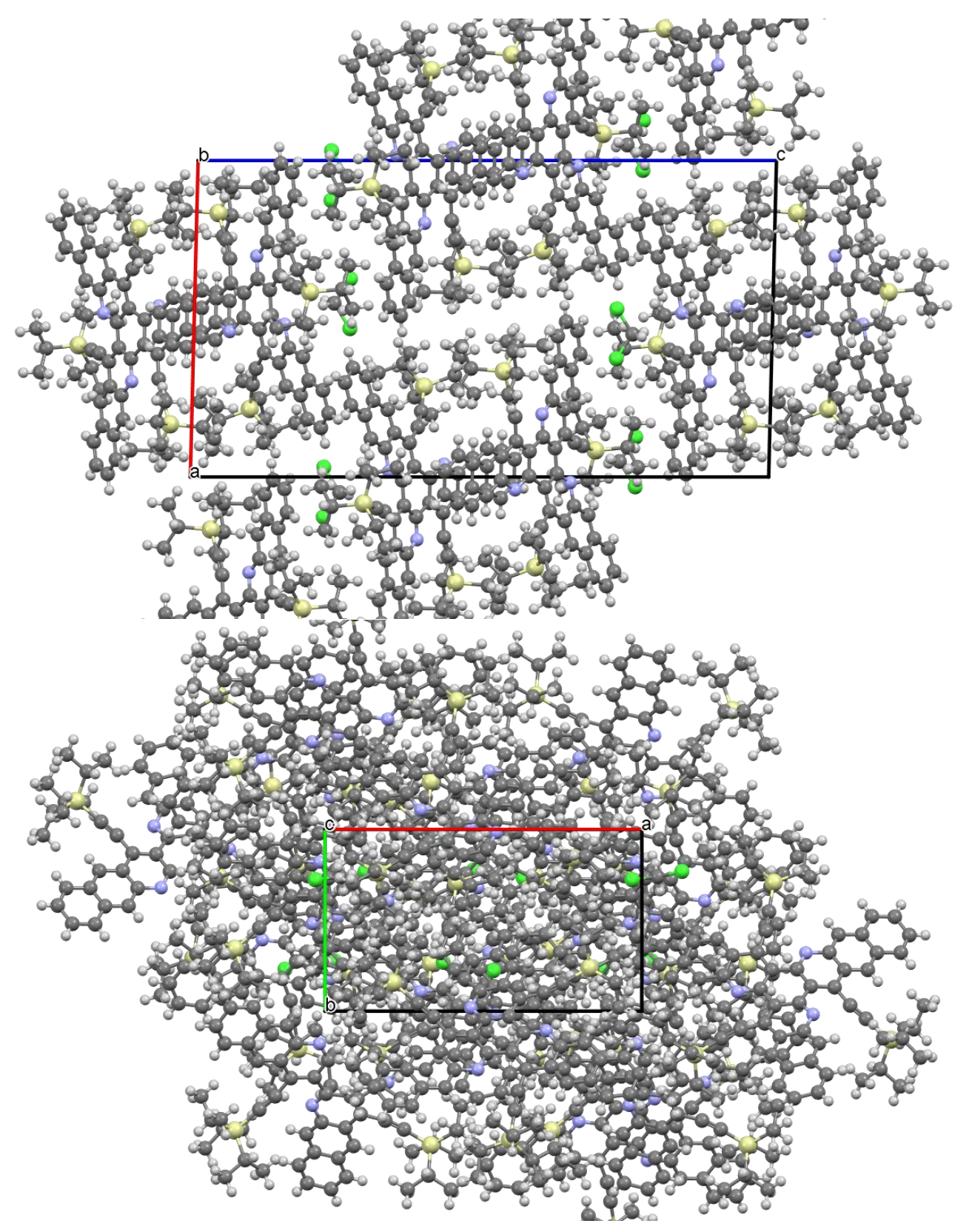

Figure S-D.5. Following three planes (100), (010) and (001). 


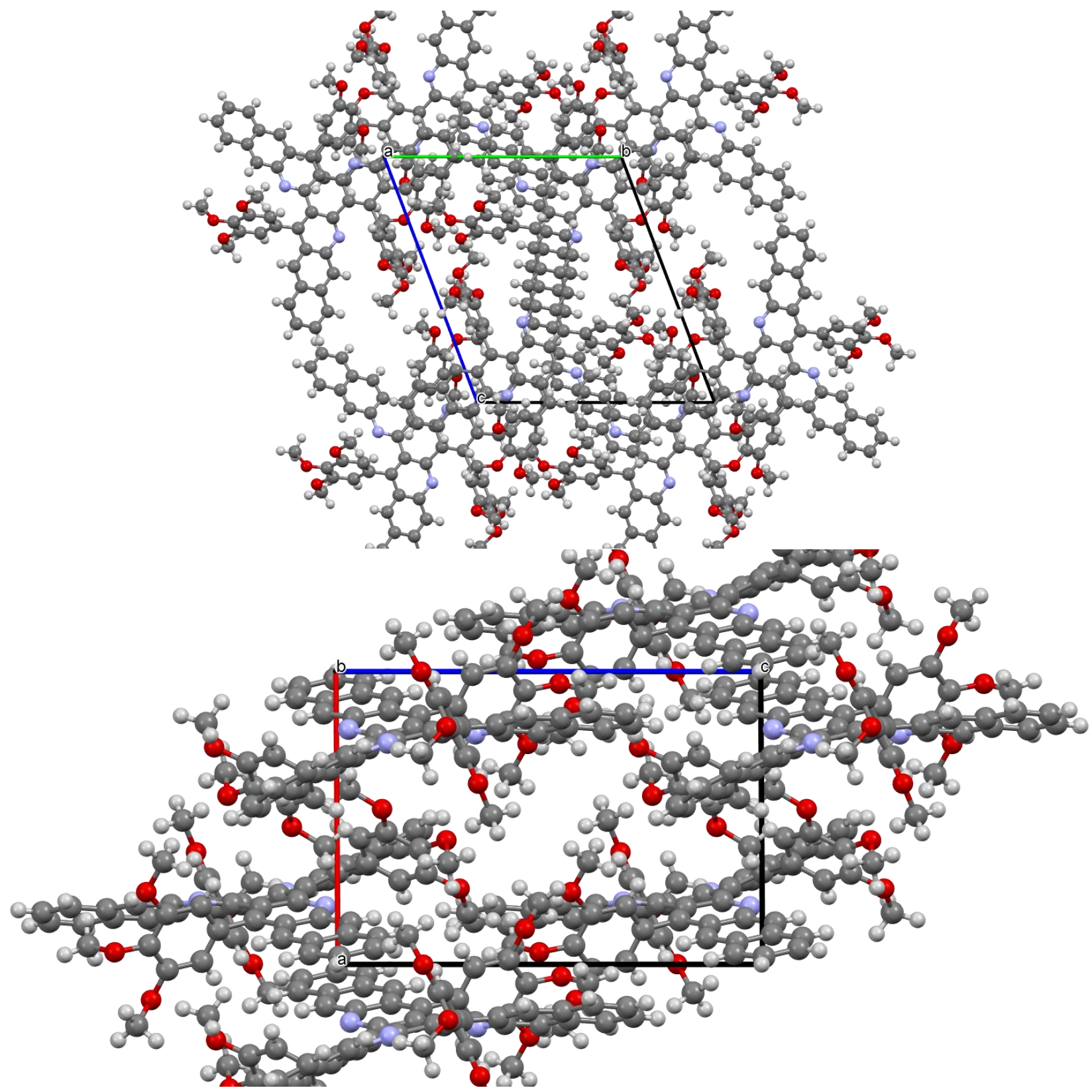




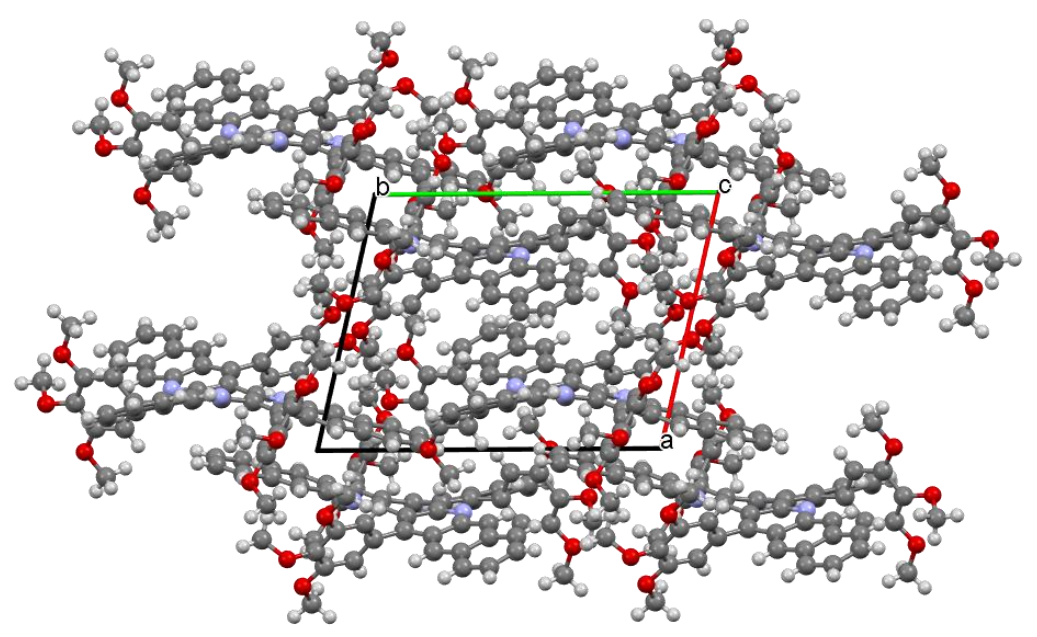

Figure S-D.6.: Following three planes (100), (010) and (001).

TAA-tBuPh

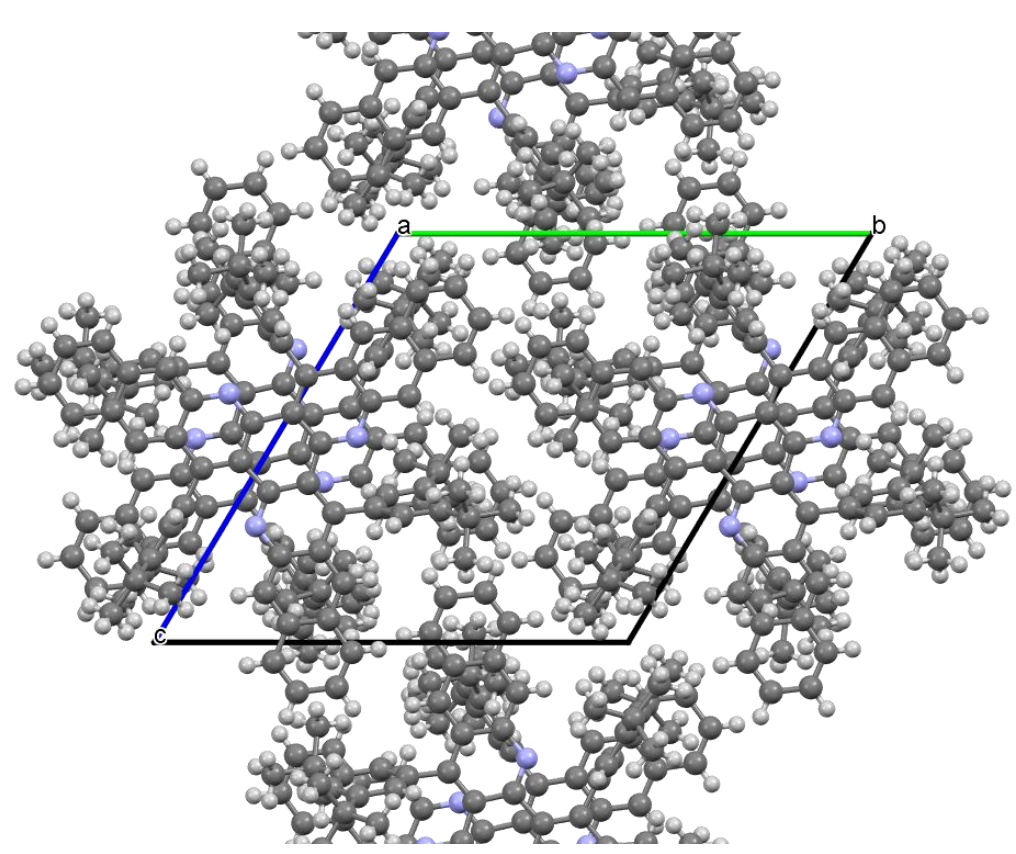




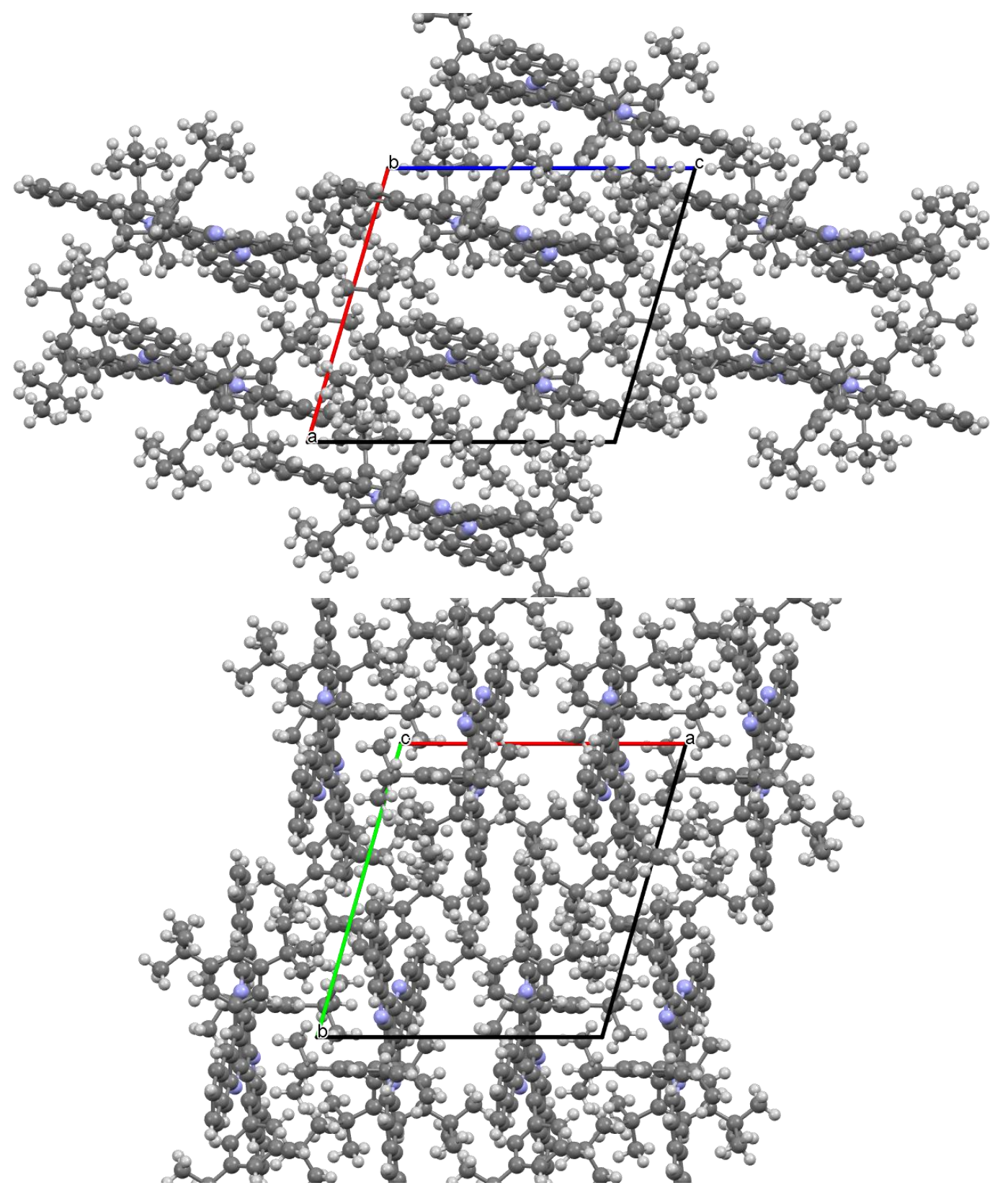

Figure S-D.7. Following three planes (100), (010) and (001). 


\section{E. DFT calculations}

Molecular geometries were optimized using the density functional theory (DFT) at the B3LYP/6-31G(d) level. Each structure was characterized as a minimum of the potential energy surface on the basis of its positive force constants issued by normal mode calculations. Internal reorganization energies for holes $\left(\lambda_{h}\right)$ and electrons $\left(\lambda_{e}\right)$ were calculated at the same level of theory, using the expression derived from the four point adiabatic potential approach: $:^{5-8}$

$$
\begin{aligned}
& \lambda_{h}=E^{(+)}(M)-E^{(0)}(M)+E^{(+)}\left(M^{+}\right)-E^{(0)}\left(M^{+}\right) \\
& \lambda_{e}=E^{(-)}(M)-E^{(0)}(M)+E^{(-)}\left(M^{-}\right)-E^{(0)}\left(M^{-}\right)
\end{aligned}
$$

where $E^{(0)}(M), E^{(+)}\left(M^{+}\right)$and $E^{(-)}\left(M^{-}\right)$denote the ground-state energy of the neutral, positively and negatively charged states, respectively; $E^{(+)}(M)\left[E^{(-)}(M)\right]$ is the energy of the neutral molecule in the optimized geometry of the cation [anion], and $E^{(0)}\left(M^{+}\right)\left[E^{(0)}\left(M^{-}\right)\right]$is the energy of the cation [anion] in the optimized geometry of the neutral molecule. Ionization energies (IE) and electron affinities (EA) are defined as:

$$
\begin{aligned}
& I E=E^{(+)}\left(M^{+}\right)-E^{(0)}(M) \\
& E A=E^{(0)}(M)-E^{(-)}\left(M^{-}\right)
\end{aligned}
$$

Transfer integrals $J_{i j}$ characterizing hole (electron) coupling between molecular pairs $i j$ within the crystals were obtained by employing the projection method involving the HOMOs (LUMOs) of monomers $i$ and $j .{ }^{9}$ Since the TAN-Ph compound possesses nearly degenerate HOMO $(\mathrm{H})$ and HOMO-1 $(\mathrm{H}-1)$ levels $\left(\mathrm{E}_{\mathrm{H}-1}=-5.657 \mathrm{eV}\right.$ and $\mathrm{E}_{\mathrm{H}}=-5.637 \mathrm{eV}$, as calculated at the B3LYP/6-31G(d) level using the crystal geometry), effective transfer integrals for hole transport in this compound were also computed as:

$$
J_{h}=\frac{1}{\sqrt{2}}\left\{J_{H-1, H-1}^{2}+J_{H-1, H}^{2}+J_{H, H-1}^{2}+J_{H, H}^{2}\right\}^{1 / 2}
$$

in line with previous works. ${ }^{10-12}$

Transition energies towards the first optically allowed excited states were computed by means of time-dependent DFT at the CAM-B3LYP/6-311G(d) level. Solvent effects were taken into account in these calculations by using the Integral Equation Formalism of the Polarizable Continuum Model (IEF-PCM) ${ }^{13}$. All calculations were performed with the ORCA ${ }^{14}$ and Gaussian ${ }^{15}$ programs. 


\section{Molecular orbitals}

A graphical representation of molecular orbitals (MOs) of the various compounds, calculated at the B3LYP/6-31G(d) level in gas phase, is given in the figures below.

\section{TAN-Ph}
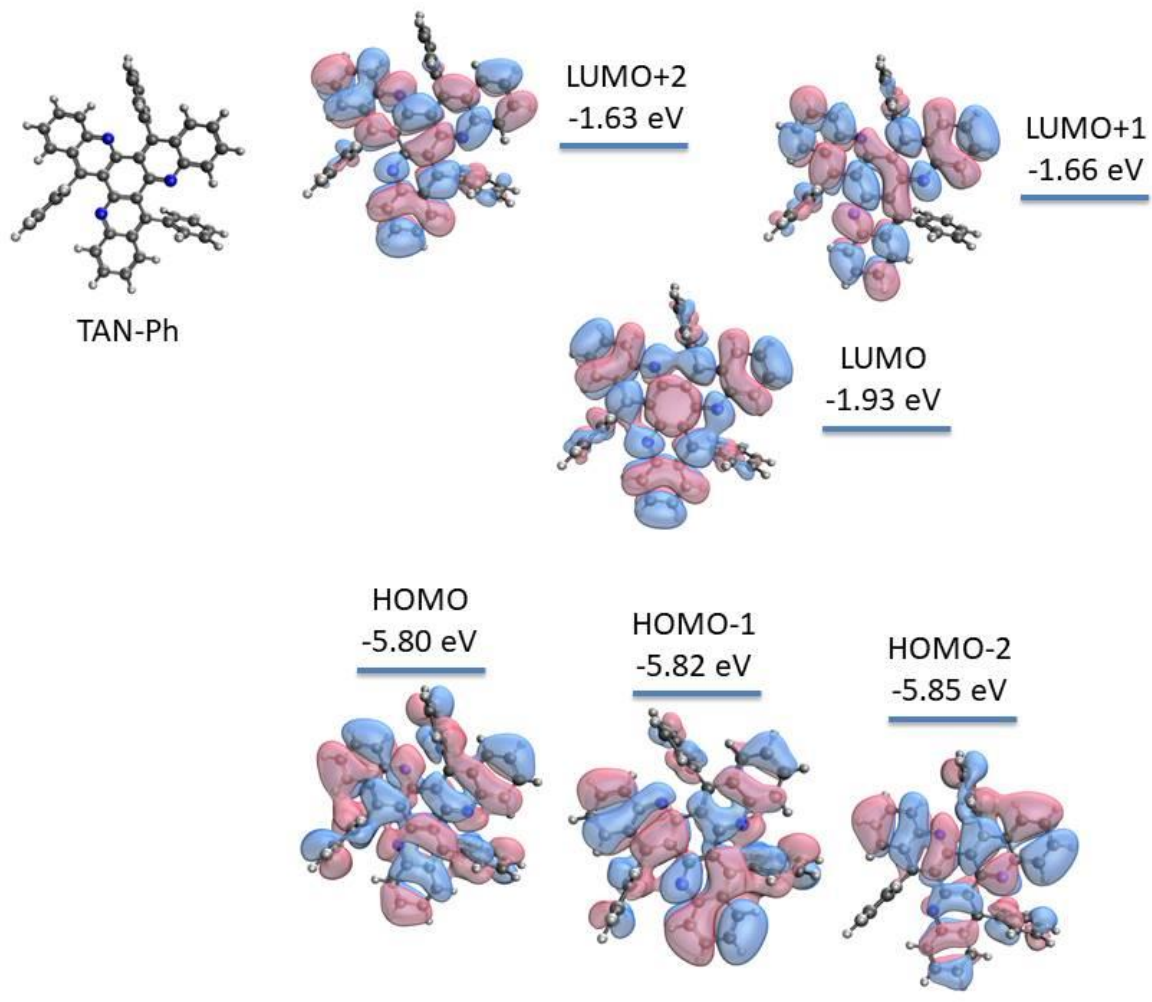

Figure S-E.1. Representation of molecular orbital of TAN-Ph. 


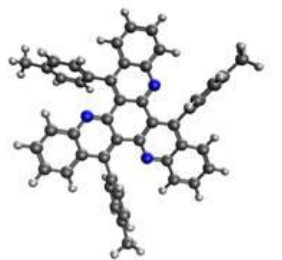

TAN-MePh

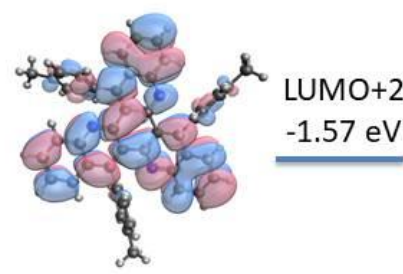

$\mathrm{LUMO}+2$
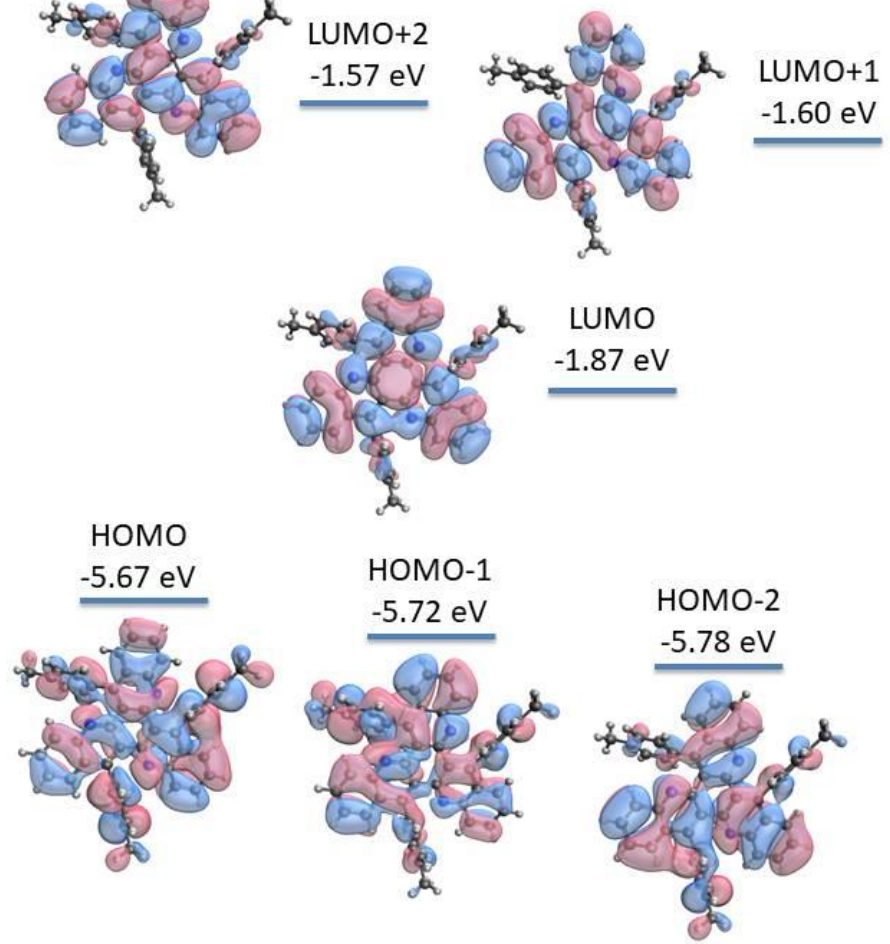

Figure S-E.2.Representation of molecular orbital of TAN-MePh.

\section{TAA-Ph}
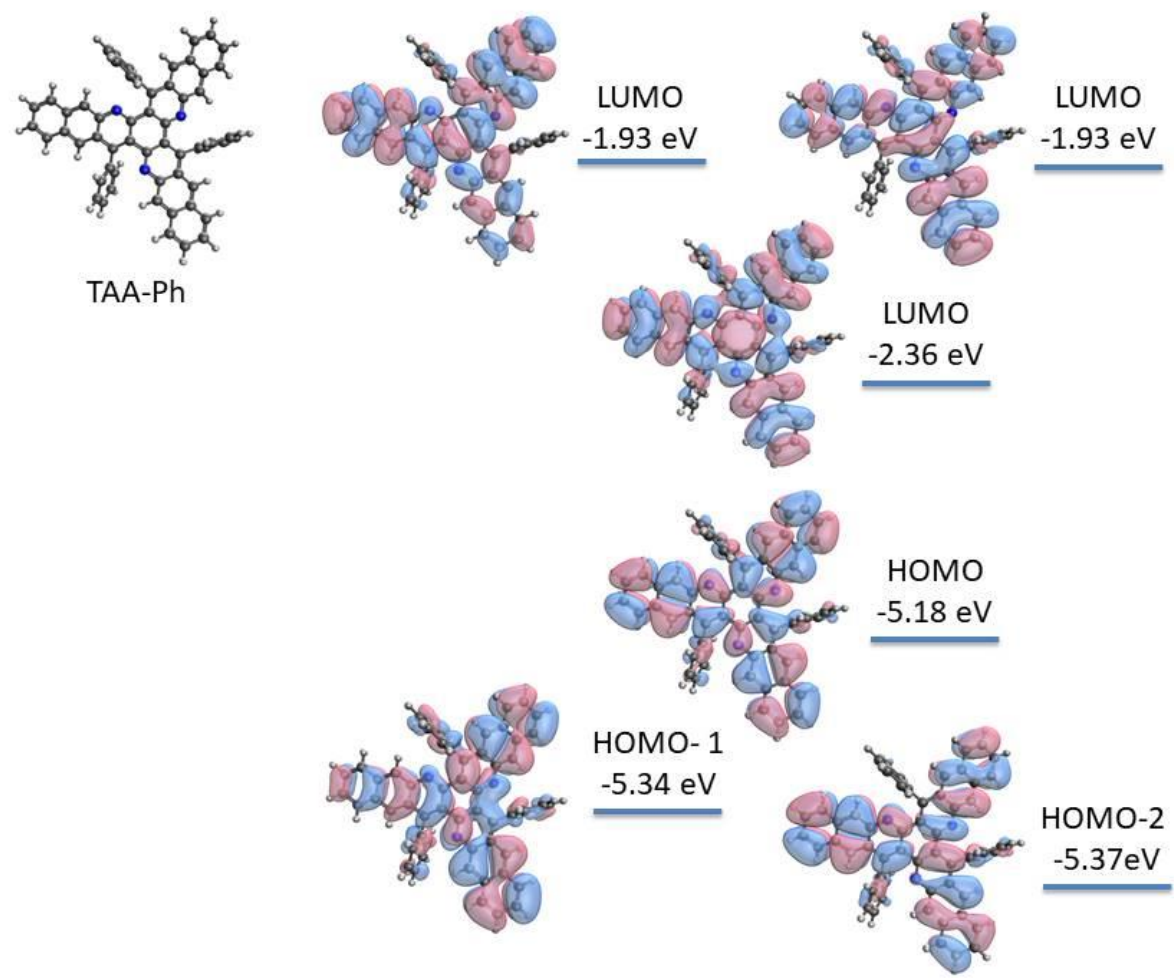

Figure S-E.3. Representation of molecular orbital of TAA-Ph. 


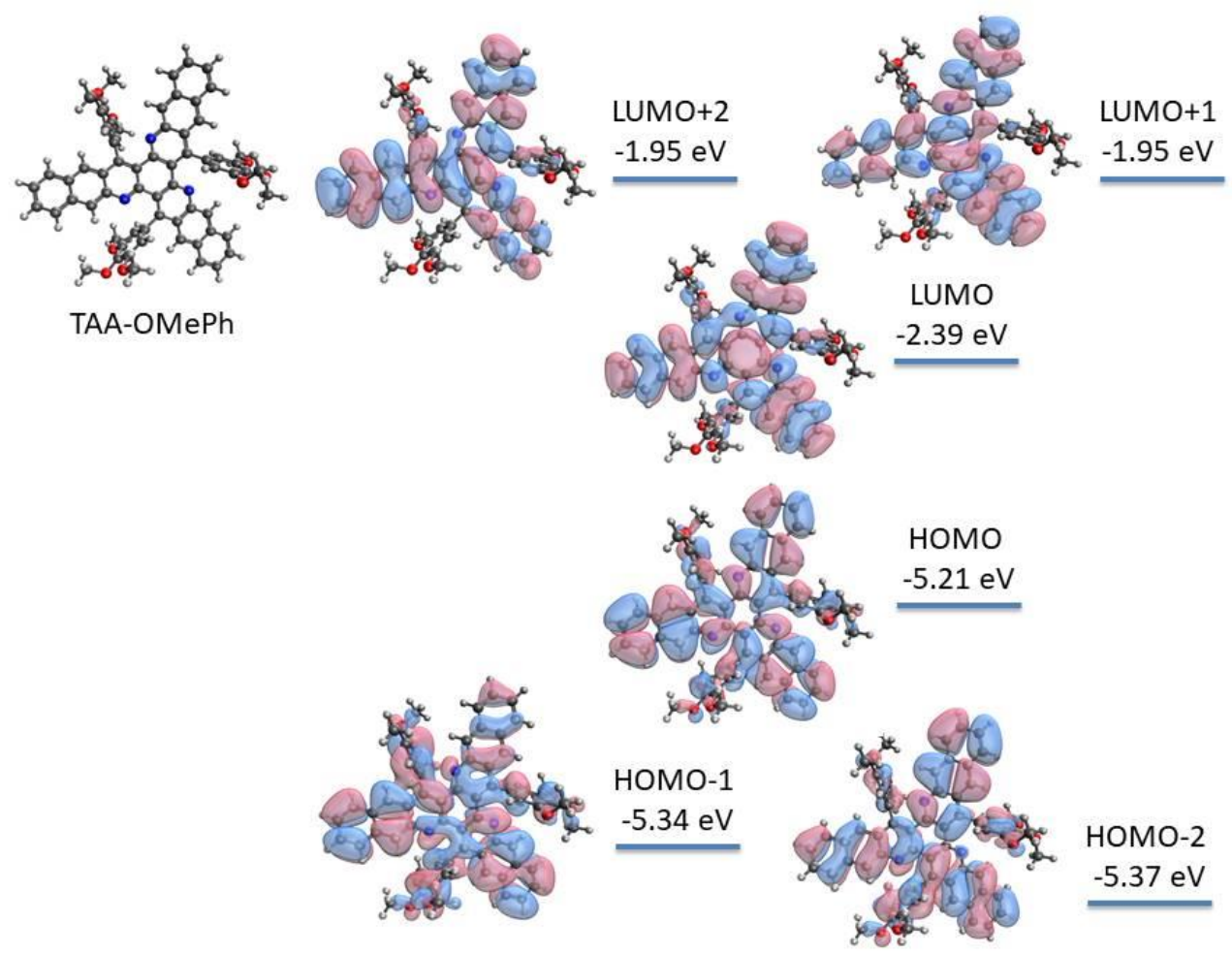

Figure S-E.4. Representation of molecular orbital of TAA-OMePh.
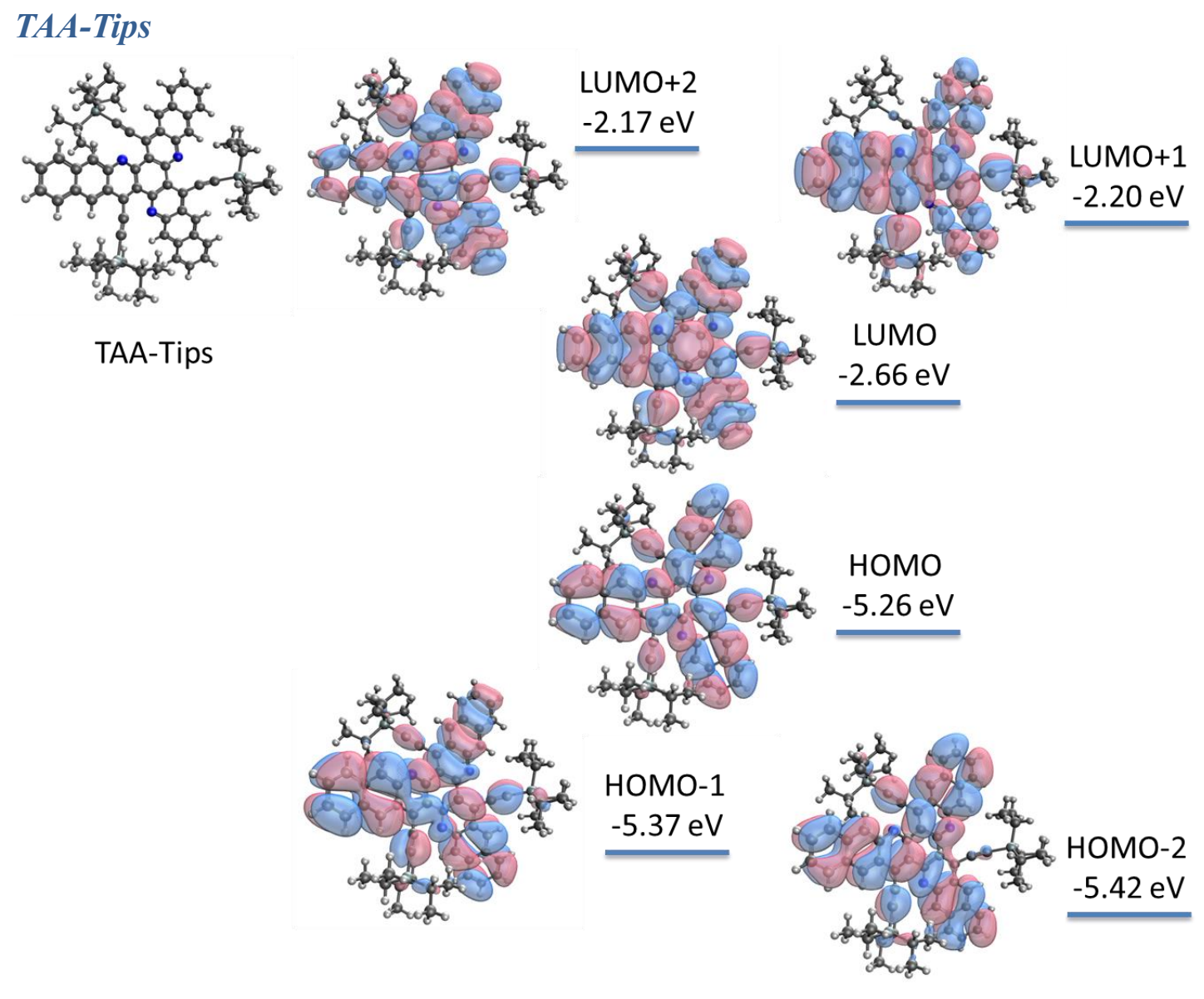
Figure S-E.5. Representation of molecular orbital of TAA-Tips.

\section{TAA-tBuPh}

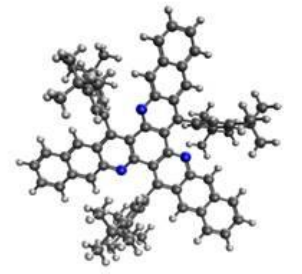

TAA-tBuPh

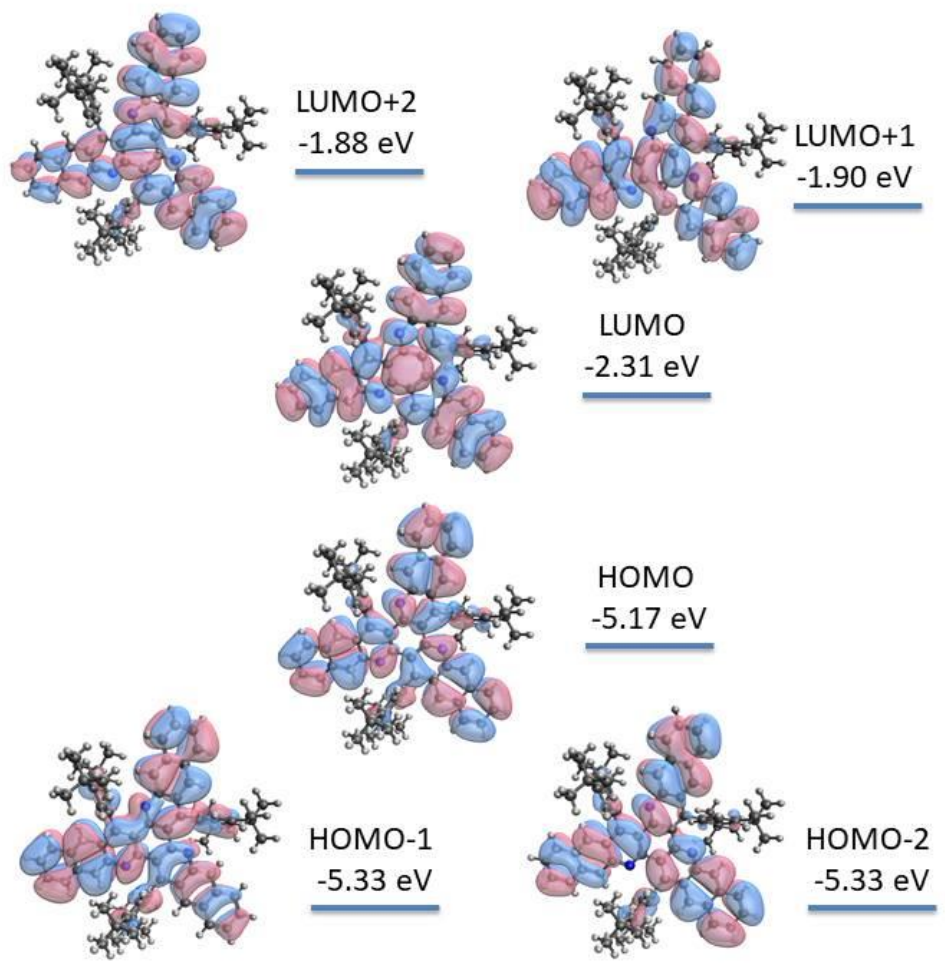

Figure S-E.6. Representation of molecular orbital of TAA-tBuPh. 


\section{$\mathrm{TAA}-\mathrm{CF}_{3} \mathrm{Ph}$}
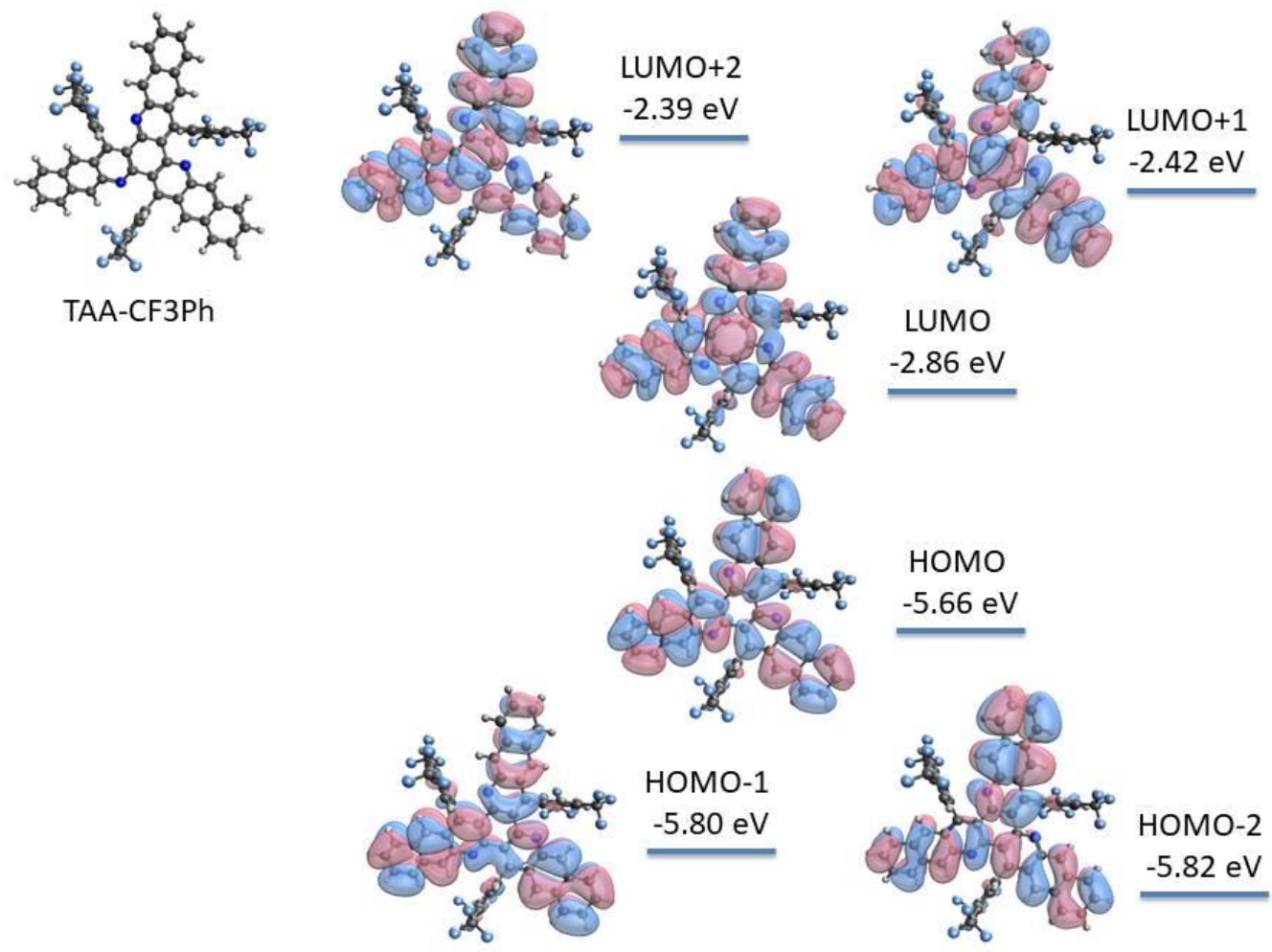

Figure S-E.7. Representation of molecular orbital of TAA-CF3Ph.
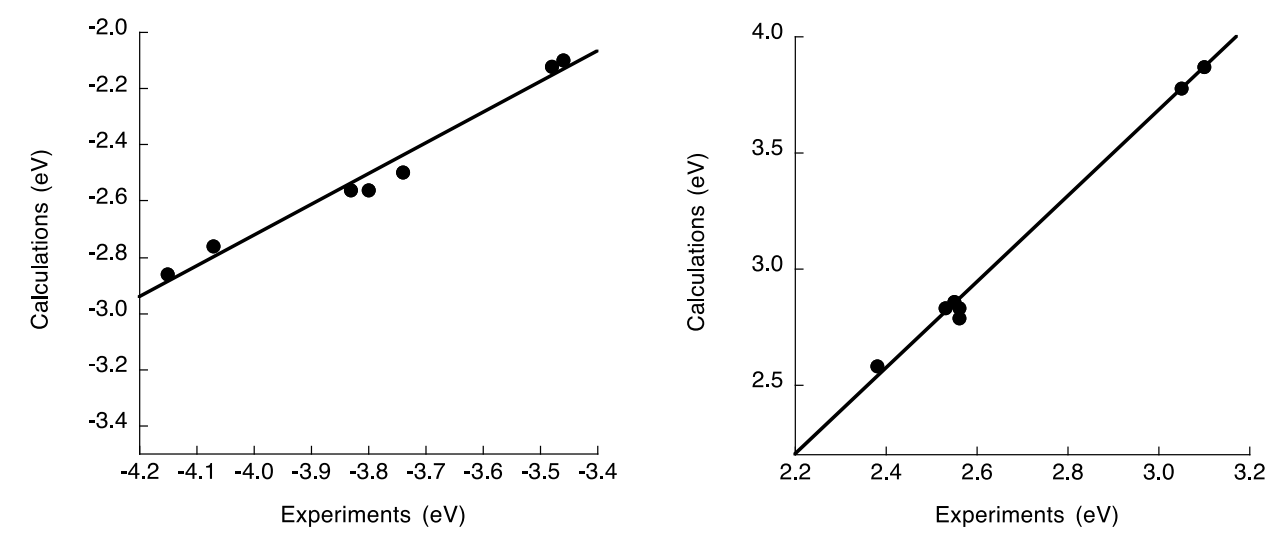

Figure S-E.8. Correlation between experimental and IEFPCM:B3LYP/6-31G(d) calculations in THF for (left) LUMO energies and (right) HOMO-LUMO gaps. 


\section{Absorption spectra}

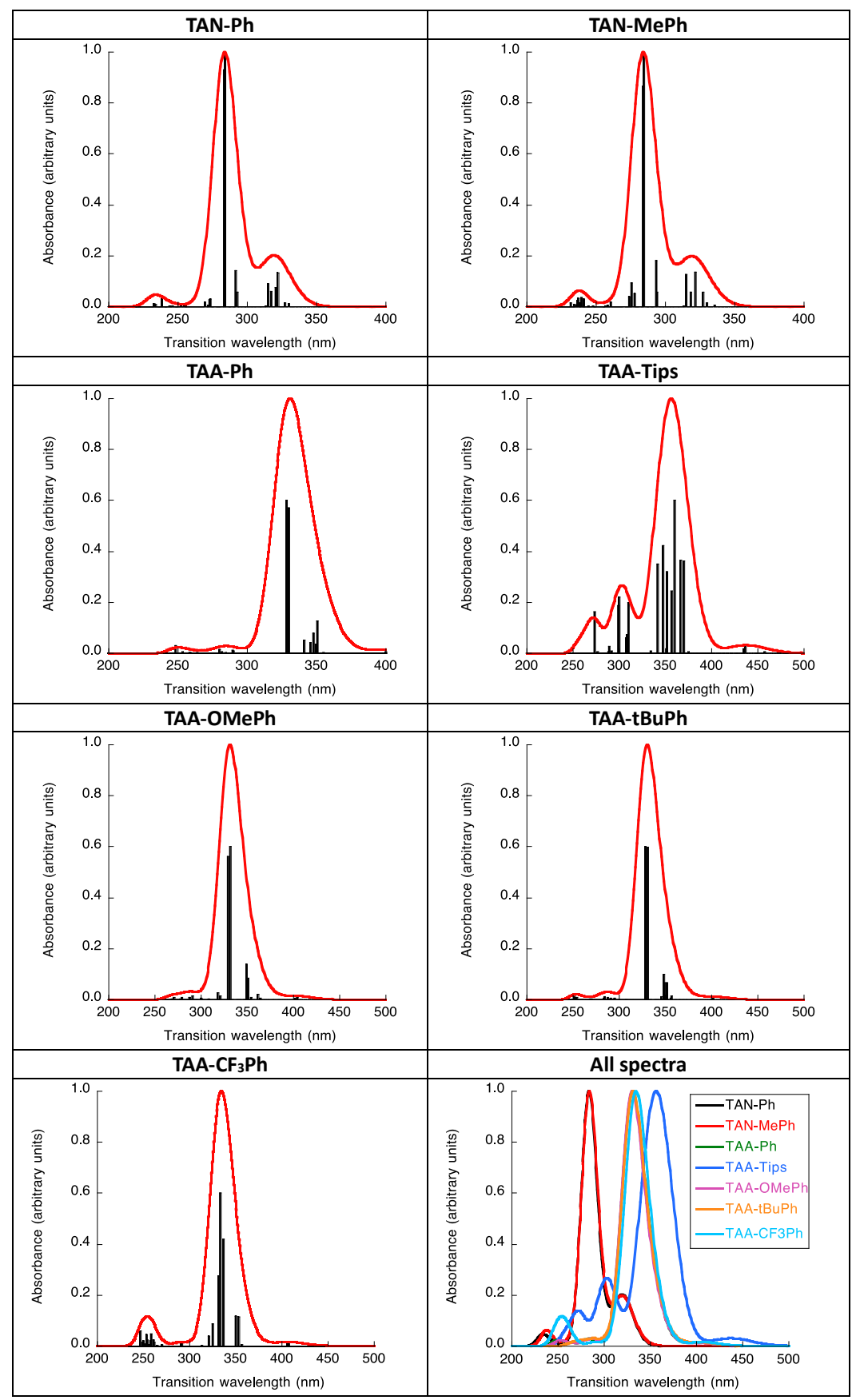

Figure S-E.9. Oscillator strengths (black bars) associated to electron excitations calculated at the IEFPCM/CAM-B3LYP/6-311G(d) level, and normalized spectra (lines), in which each transition has been enlarged by using a Gaussian function with a full width at half maximum (FWHM) equal to $0.3 \mathrm{eV}$. 


\section{Calculated absorption properties}

\section{TAN-Ph}

(HOMO = MO 159; LUMO = MO 160)

\begin{tabular}{|c|c|c|c|}
\hline Excited & State & 1: & Singlet \\
\hline 147 & $->160$ & & -0.12649 \\
\hline 155 & $->161$ & & 0.15423 \\
\hline 155 & $->162$ & & -0.14473 \\
\hline 15 & $->160$ & & 0.28720 \\
\hline $15^{-}$ & $->160$ & & 0.23417 \\
\hline $15^{-}$ & $->162$ & & -0.12274 \\
\hline $15 \varepsilon$ & $->160$ & & -0.12393 \\
\hline $15 \varepsilon$ & $->162$ & & 0.14420 \\
\hline 15 & $->160$ & & 0.38013 \\
\hline & $->161$ & & -0.1379 \\
\hline
\end{tabular}

Excited State

2: $\quad$ Singlet-A

$154->160 \quad 0.12710$

$154->161 \quad 0.11615$

$156->160 \quad-0.13493$

$157->160 \quad 0.36749$

$158->160 \quad 0.17947$

$158->162 \quad 0.25513$

$159->160 \quad-0.19218$

$159->161 \quad-0.27894$

$159->162-0.15156$

Excited State

$155->160$

3:

Singlet-A

$-0.30425$

$\begin{array}{rr}155->161 & 0.10121 \\ 156->161 & -0.10199\end{array}$

$156->162$

0.12589

$158->160$

0.42418

$159->160$

0.19251

$159->161$

$-0.17100$

$159->162$

0.13357

Excited State

$145->160$

$4:$

Singlet-A

0.12264

0.31366

$155->160$

$-0.12961$

$155->161$

$-0.10523$

0.17472

$156->161$

0.31522

$-0.17930$

0.27464

0.11035

$-0.11132$

Excited State

$148->160$

5:

Singlet-A

$-0.13679$

$154->160$

$-0.14331$

$-0.12928$

0.10828

$155->162$

$-0.22746$

$156->160$

0.12854

$156->161$

$-0.15513$

$158->160$

0.19597

$3.7646 \mathrm{eV} \quad 329.35 \mathrm{~nm} \quad \mathrm{f}=0.0280$

$3.7970 \mathrm{eV} \quad 326.54 \mathrm{~nm} \quad \mathrm{f}=0.0342$

$3.8507 \mathrm{eV} \quad 321.98 \mathrm{~nm} \quad \mathrm{f}=0.2804$

$3.8713 \mathrm{eV} \quad 320.27 \mathrm{~nm} \quad \mathrm{f}=0.1604$

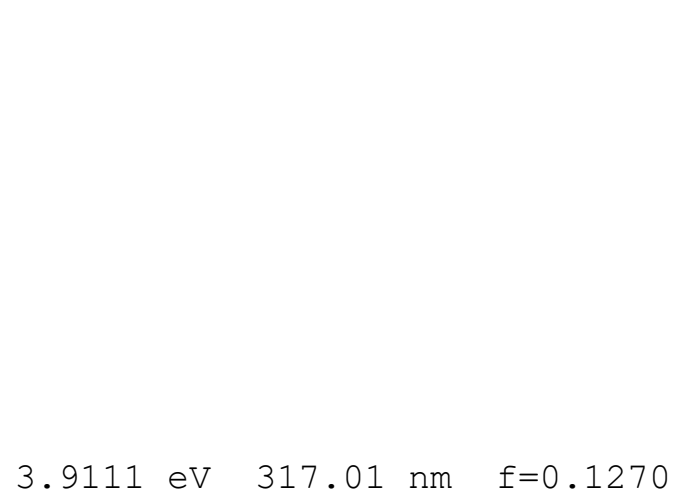

$3.9111 \mathrm{eV} \quad 317.01 \mathrm{~nm} \quad \mathrm{f}=0.1270$ 


\begin{tabular}{|c|c|c|c|c|c|c|c|c|}
\hline 158 & $->162$ & & 0.25718 & & & & & \\
\hline 159 & $->160$ & & 0.19206 & & & & & \\
\hline 159 & $->161$ & & -0.17767 & & & & & \\
\hline 159 & $->162$ & & 0.30530 & & & & & \\
\hline Excited & State & $6:$ & Singlet-A & 3.9440 & $\mathrm{eV}$ & 314.36 & $\mathrm{~nm}$ & $f=0.1944$ \\
\hline 154 & $->160$ & & -0.17700 & & & & & \\
\hline 154 & $->161$ & & -0.12373 & & & & & \\
\hline 154 & $->162$ & & -0.15913 & & & & & \\
\hline 155 & $->160$ & & 0.13938 & & & & & \\
\hline 156 & $->160$ & & 0.30997 & & & & & \\
\hline 156 & $->161$ & & 0.16270 & & & & & \\
\hline 158 & $->160$ & & 0.21988 & & & & & \\
\hline 158 & $->161$ & & 0.17676 & & & & & \\
\hline 159 & $->160$ & & -0.26210 & & & & & \\
\hline 159 & $->161$ & & -0.10215 & & & & & \\
\hline 159 & $->162$ & & 0.10922 & & & & & \\
\hline Excited & State & $7:$ & Singlet-A & 3.9687 & $\mathrm{eV}$ & 312.40 & $\mathrm{~nm}$ & $f=0.0069$ \\
\hline 146 & $->160$ & & 0.13663 & & & & & \\
\hline 154 & $->160$ & & 0.36980 & & & & & \\
\hline 154 & $->161$ & & 0.14360 & & & & & \\
\hline 155 & $->160$ & & 0.12647 & & & & & \\
\hline 155 & $->162$ & & -0.11048 & & & & & \\
\hline 156 & $->162$ & & -0.24931 & & & & & \\
\hline 157 & $->160$ & & -0.13046 & & & & & \\
\hline 158 & $->161$ & & 0.30816 & & & & & \\
\hline 159 & $->162$ & & 0.18573 & & & & & \\
\hline Excited & state & $8:$ & Singlet-A & 4.2409 & $\mathrm{eV}$ & 292.35 & $\mathrm{~nm}$ & $f=0.1219$ \\
\hline 149 & $->160$ & & -0.12412 & & & & & \\
\hline 150 & $->160$ & & -0.16837 & & & & & \\
\hline 153 & $->160$ & & -0.14617 & & & & & \\
\hline 157 & $->161$ & & 0.51764 & & & & & \\
\hline 157 & $->162$ & & -0.24057 & & & & & \\
\hline 158 & $->164$ & & -0.12327 & & & & & \\
\hline 159 & $->162$ & & 0.10257 & & & & & \\
\hline 159 & $->163$ & & -0.13479 & & & & & \\
\hline Excited & state & $9:$ & Singlet-A & 4.2548 & $\mathrm{eV}$ & 291.40 & $\mathrm{~nm}$ & $f=0.3018$ \\
\hline 149 & $->160$ & & -0.16611 & & & & & \\
\hline 150 & $->160$ & & 0.13359 & & & & & \\
\hline 152 & $->160$ & & 0.13702 & & & & & \\
\hline 157 & $->161$ & & 0.20412 & & & & & \\
\hline 157 & $->162$ & & 0.44742 & & & & & \\
\hline 158 & $->162$ & & 0.22286 & & & & & \\
\hline 158 & $->163$ & & -0.13040 & & & & & \\
\hline 159 & $->161$ & & 0.18763 & & & & & \\
\hline 159 & $->164$ & & 0.12041 & & & & & \\
\hline Excited & state & $10:$ & Singlet-A & 4.3758 & $\mathrm{eV}$ & 283.34 & $\mathrm{~nm}$ & $f=2.1090$ \\
\hline 157 & $->161$ & & -0.12313 & & & & & \\
\hline 157 & $->164$ & & 0.10719 & & & & & \\
\hline 158 & $->161$ & & -0.41910 & & & & & \\
\hline 158 & $->162$ & & 0.10116 & & & & & \\
\hline 159 & $->160$ & & -0.10743 & & & & & \\
\hline 159 & $->161$ & & 0.11305 & & & & & \\
\hline 159 & $->162$ & & 0.43041 & & & & & \\
\hline
\end{tabular}




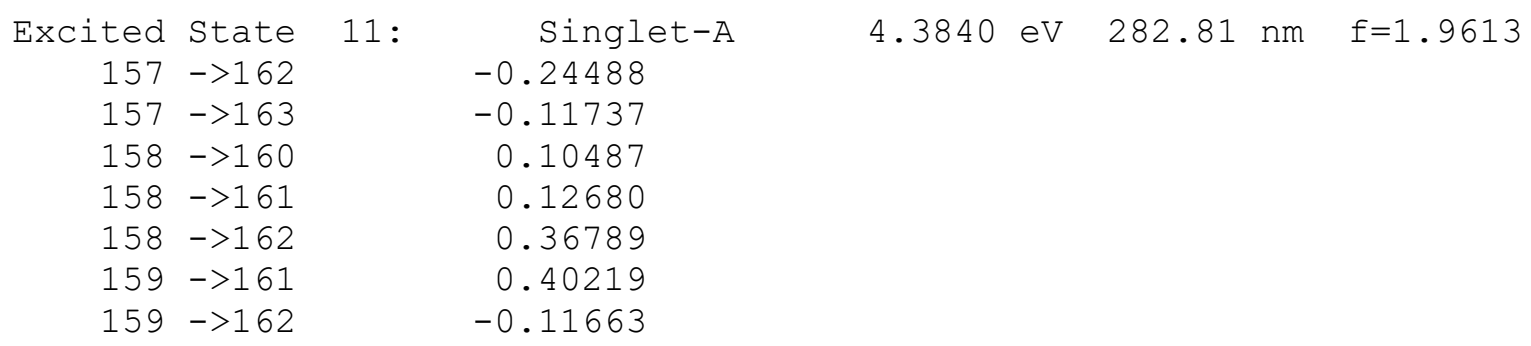

\section{TAN-MePh}

( $\mathrm{HOMO}=$ MO 171; LUMO $=$ MO 172)

$\begin{array}{cr}\text { Excited State } 1: & \text { Singlet } \\ 160->172 & -0.14537 \\ 167->172 & -0.21200 \\ 168->173 & 0.15688 \\ 168->174 & -0.14716 \\ 169->172 & 0.21732 \\ 169->174 & -0.15061 \\ 170->173 & -0.10774 \\ 171->172 & 0.44551 \\ 171->173 & -0.15262\end{array}$

Excited State

$167->172$

2: $\quad$ Singlet-A

0.13423

$169->172$

0.32183

$169->173$

0.14495

$170->172$

0.30444

$170->174$

0.25383

$171->172$

$-0.15808$

$171->173$

$-0.23627$

$171->174$

$-0.15589$

Excited State

$157->172$

3:

Singlet-A

0.12658

0.11348

$160->174$
$167->172$

0.12260

$167->173$

$-0.15723$

$168->172$

0.39252

$168->174$

-0.16560
0.13757

$169->172$

$169->173$

0.11080

$170->172$

$-0.22470$

$171->173$

0.21256

$171->174$

$-0.16669$

Excited State

$167->172$

$4:$

Singlet-A

0.16614

$167->173$

$-0.11706$

$168->172$

0.15669

$169->172$

$-0.25236$

$170->172$

0.41980

$170->173$

$-0.13460$

$171->172$

0.24169

Excited State
$159 \rightarrow 172$

$5:$

Singlet-A

0.13420

$166->172$

$-0.20543$

$167->172$

0.23631

$3.7093 \mathrm{eV} \quad 334.25 \mathrm{~nm} \quad \mathrm{f}=0.0152$

$3.7620 \mathrm{eV} \quad 329.57 \mathrm{~nm} \quad \mathrm{f}=0.0341$

$3.7985 \mathrm{eV} \quad 326.40 \mathrm{~nm} \quad \mathrm{f}=0.1199$

$3.8660 \mathrm{eV} \quad 320.71 \mathrm{~nm} \quad \mathrm{f}=0.2781$

$3.9042 \mathrm{eV} \quad 317.57 \mathrm{~nm} \quad f=0.1165$ 


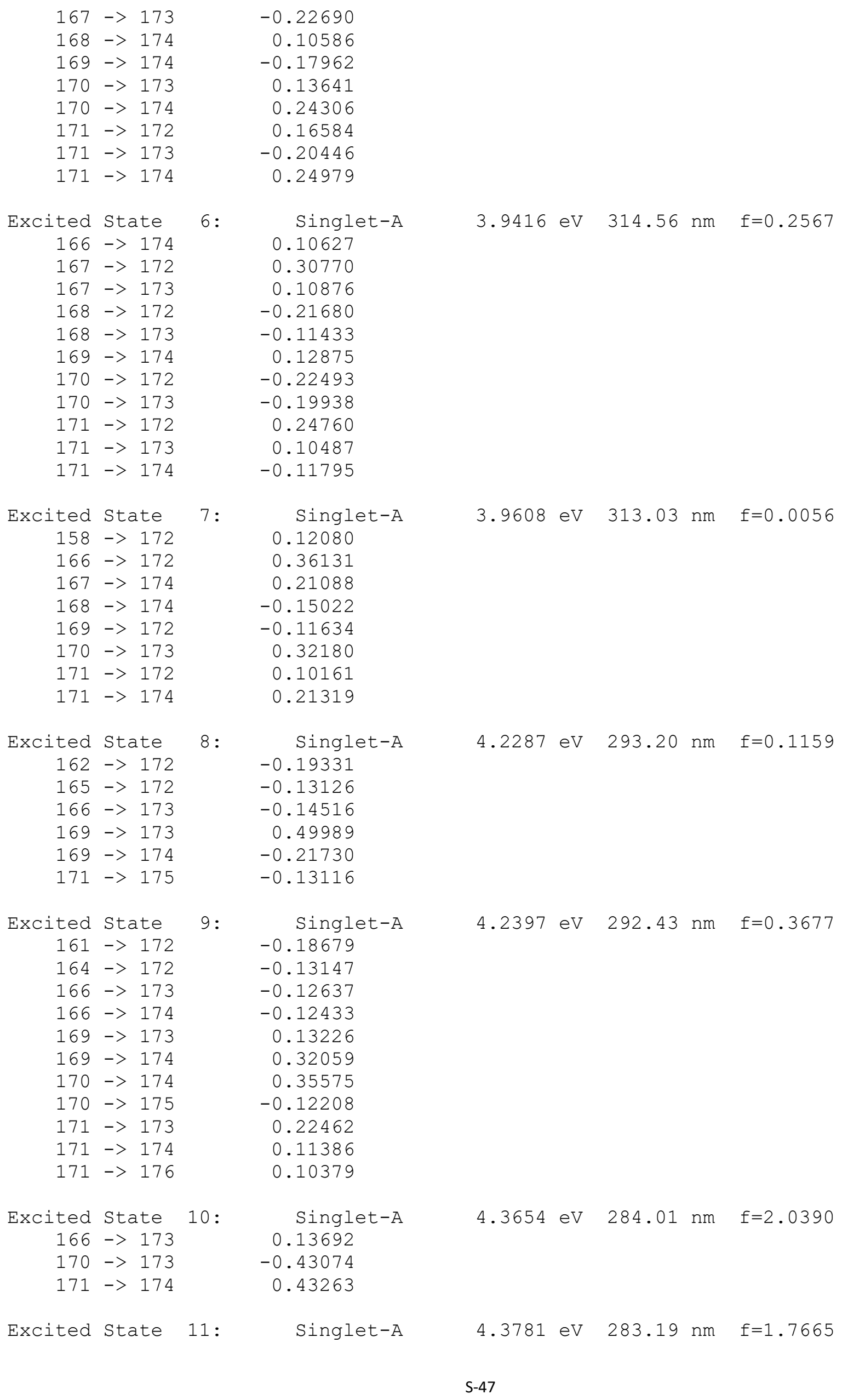

Excited State 11: Singlet-A $\quad 4.3781 \mathrm{eV} \quad 283.19 \mathrm{~nm} \quad \mathrm{f}=1.7665$

$3.9416 \mathrm{eV} \quad 314.56 \mathrm{~nm} \quad f=0.2567$

$3.9608 \mathrm{eV} \quad 313.03 \mathrm{~nm} \quad \mathrm{f}=0.0056$

$4.2287 \mathrm{eV} \quad 293.20 \mathrm{~nm} \quad \mathrm{f}=0.1159$

$4.2397 \mathrm{eV} \quad 292.43 \mathrm{~nm} \quad \mathrm{f}=0.3677$ 


$\begin{array}{rr}166->174 & 0.14387 \\ 169->173 & -0.13410 \\ 169->174 & -0.33589 \\ 169->175 & -0.11937 \\ 170->172 & 0.12174 \\ 170->174 & 0.25902 \\ 171->173 & 0.39310\end{array}$

\section{TAA-Ph}

(HOMO = MO 198; LUMO = MO 199)

Excited State
$196->201$
$197->200$
$-0.26901$
$198->199$
0.25232
0.58087

$1:$

Excited State

$196->199$

$196->200$

$197->199$

$198->200$

$198->201$

Excited State

$196->199$

$197->199$

$197->200$

$198->200$

$198->201$

Excited State

$187->199$

$191->200$

$192->201$

$194->199$

$196->200$

$196->202$

$197->200$

$197->201$

$198->205$

Excited State

$187->201$

$191->199$

$191->201$

$192->199$

$192->200$

$193->199$

$194->199$

$195->199$

$196->201$

$197->199$

$197->200$

$198->200$

$198->201$

Excited State

$185->199$

$192->199$

$193->200$
2:

2: $\quad$ Singlet-A

$-0.33130$

0.10992

0.47921

0.19187

0.23923

3

Singlet-A

0.47952

0.33206

0.14726

0.22447

$-0.20707$

4:

Singlet-A

0.14779

$-0.10289$

$-0.14797$

$-0.11506$

0.37741

0.10652

$-0.12544$

0.39761

0.12180

$5:$

Singlet-A

$-0.11482$

0.13044

$-0.11019$

0.20129

$-0.11714$

0.10254

0.14177

$-0.27875$

0.14166

$-0.18226$

0.17911

0.34177

$-0.10827$

6:

Singlet-A

$-0.12424$

0.15731

$-0.10960$
$2.9668 \mathrm{eV} \quad 417.90 \mathrm{~nm} \quad \mathrm{f}=0.0022$

$3.0863 \mathrm{eV} \quad 401.72 \mathrm{~nm} \quad \mathrm{f}=0.0438$

$3.1024 \mathrm{eV} \quad 399.64 \mathrm{~nm} \quad \mathrm{f}=0.0231$

$3.4967 \mathrm{eV} \quad 354.58 \mathrm{~nm} \quad \mathrm{f}=0.0099$

$3.5424 \mathrm{eV} \quad 350.00 \mathrm{~nm} \quad f=0.5487$ 


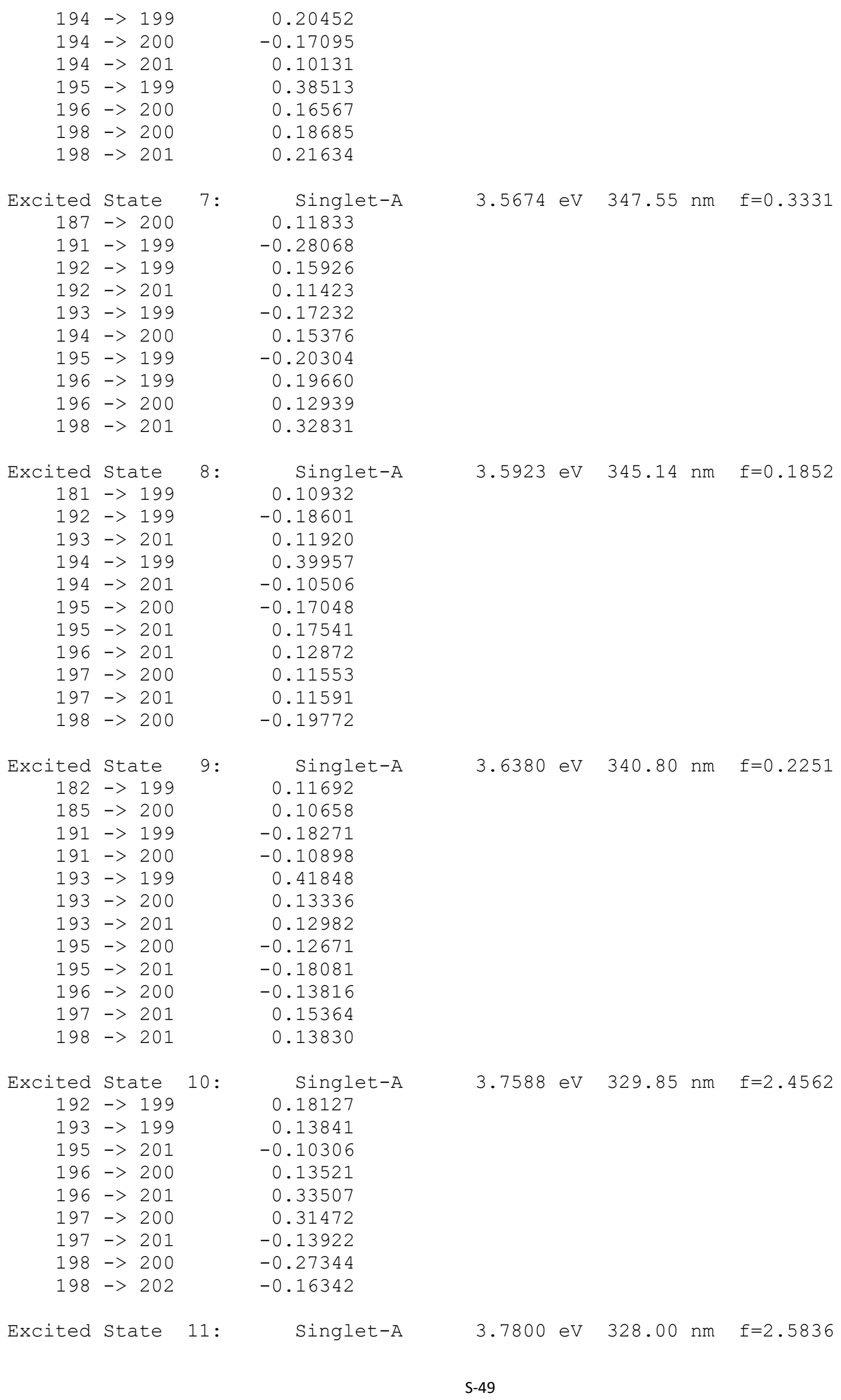

Excited State 10:
$192->199$
0.18127
$193->199$
0.13841
$195->201$
$-0.10306$
$196->200$
0.13521
0.33507
0.31472
$-0.13922$
$-0.27344$
$-0.16342$
$197->200$
$197->201$
$198->200$

Singlet-A

$3.5923 \mathrm{eV} \quad 345.14 \mathrm{~nm} \quad \mathrm{f}=0.1852$

Excited State 11: $\quad$ Singlet-A $\quad 3.7800 \mathrm{eV} \quad 328.00 \mathrm{~nm} \quad \mathrm{f}=2.5836$ 


$\begin{array}{rr}191 \rightarrow>199 & 0.19858 \\ 196->200 & -0.32799 \\ 196->201 & 0.13607 \\ 197->200 & 0.14629 \\ 197->201 & 0.35290 \\ 198->201 & 0.23615 \\ 198->203 & -0.14136\end{array}$

\section{TAA-tBuPh}

( $\mathrm{HOMO}=$ MO 294; LUMO = MO 295)

Excited State 1:

$292->297$

$293->296$

$294->295$

Excited State

$292->295$

$293->295$

$293->296$

$294->296$

$294->297$

Excited State

$292->295$

$293->295$

$293->296$

$294->296$

$294->297$

Excited State

$290->295$

$291->295$

$291->296$

$291->297$

$292->296$

$293->296$

$293->297$

Excited State

$282->295$

$290->295$

$290->296$

$291->295$

$291->297$

$292->296$

$293->296$

$293->297$

Excited State

$283->295$

$290->295$

$290->296$

$291->296$

$291->297$

$292->296$

$292->297$

$293->297$

$294->296$
$1:$

$-0.26503$

0.24686

0.57941

2:

$$
\begin{array}{r}
-0.36831 \\
0.44919 \\
0.12036 \\
0.14904 \\
0.26887
\end{array}
$$

$3:$

Singlet-A

0.44891

0.37137

0.10295

0.26244

$-0.16525$

$4:$

Singlet-A

0.12634

0.35235

0.14324

$-0.16194$

0.31216

$-0.15631$

0.22306

$5:$

Singlet-A

0.15300

$-0.25626$

0.23504

0.36428

$-0.11403$

$-0.13678$

0.10733

$-0.25880$

$6:$

Singlet-A

$-0.10778$

0.38537

$-0.14663$

0.15989

$-0.11781$

$-0.13725$

$-0.19674$

$-0.22653$

$-0.12089$
$2.9726 \mathrm{eV} \quad 417.08 \mathrm{~nm} \quad \mathrm{f}=0.0010$

$3.0916 \mathrm{eV} \quad 401.04 \mathrm{~nm} \quad \mathrm{f}=0.0398$

$3.1078 \mathrm{eV} \quad 398.95 \mathrm{~nm} \quad \mathrm{f}=0.0168$

$3.4867 \mathrm{eV} \quad 355.59 \mathrm{~nm} \quad \mathrm{f}=0.0672$

$3.4994 \mathrm{eV} \quad 354.30 \mathrm{~nm} \quad \mathrm{f}=0.0285$

$3.5315 \mathrm{eV} \quad 351.08 \mathrm{~nm} \quad \mathrm{f}=0.2874$ 


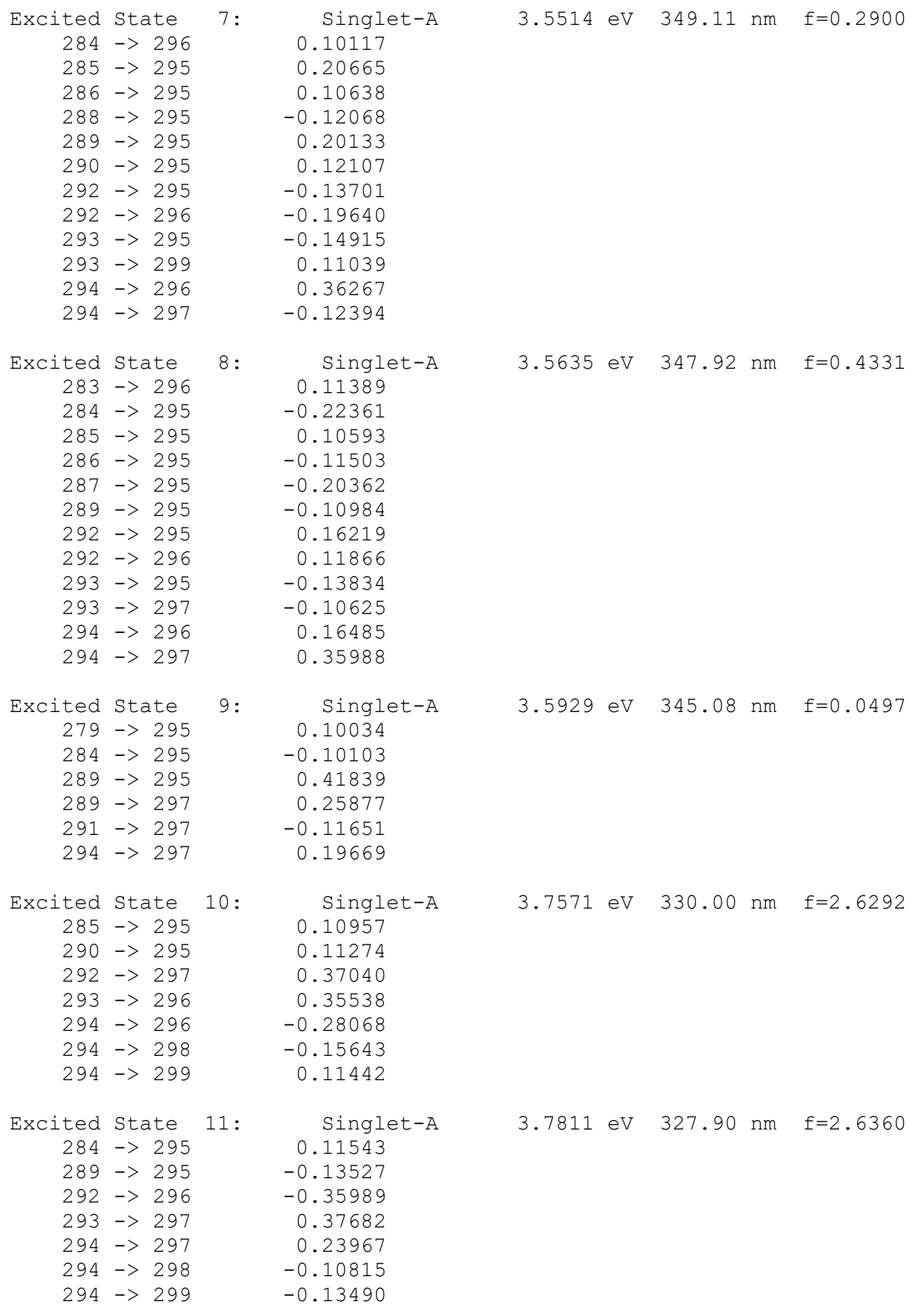

\section{TAA-OMePh}

\section{(HOMO = MO 270; LUMO = MO 271)}

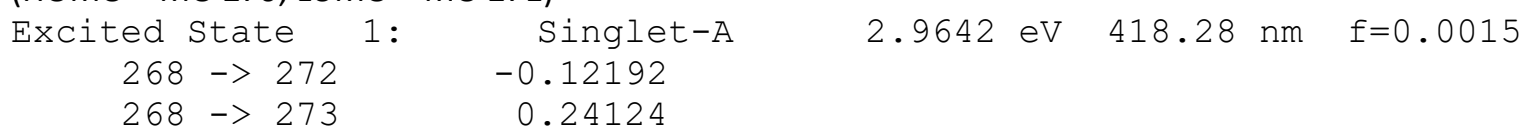



$269->272$
0.22701
$269->273$
0.13916
$270->271$
0.58015

Excited State

$268->271$

$268->272$

$269->271$

$270->272$

$270->273$

Excited State 3:

$268->271$

$269->271$

$269->272$

$270->272$

$270->273$

Excited State

$257->271$

$258->271$

$258->272$

$266->271$

$266->272$

$267->271$

$269->272$

Excited State

$257->271$

$257->273$

$258->271$

$266->271$

$266->273$

$267->271$

$267->272$

$267->273$

$268->272$

$269->272$

Excited State

$259->271$

$260->272$

$261->273$

$267->271$

$268->272$

$268->273$

$269->272$

$269->273$

$270->277$

Excited State

$259->273$

$260->272$

$261->271$

$265->271$

$268->271$

$268->272$

$268->275$

$269->271$
2:

$$
\begin{gathered}
\text { Singlet-A } \\
0.27162 \\
-0.10353 \\
0.51748 \\
0.15778 \\
0.25869
\end{gathered}
$$

$3:$

Singlet-A

0.51674

$-0.26924$

$-0.13009$

$-0.25394$

0.16466

$4:$

Singlet-A

$-0.15319$

$-0.14268$

0.11871

0.44223

$-0.27347$

0.24171

0.14794

5:

Singlet-A

$-0.12704$

0.11985

0.17483

$-0.26604$

0.10130

0.41738

0.19888

$-0.19840$

0.13310

0.13924

6:

Singlet-A

0.16953

$-0.12911$

$-0.15833$

0.16128

$-0.29652$

$-0.23065$

$-0.13131$

0.36500

$-0.11695$

7:

Singlet-A

$-0.11221$

0.10061

0.30988

$-0.20075$

0.12293

0.13221

$-0.10630$

$-0.15112$
$3.0745 \mathrm{eV} \quad 403.26 \mathrm{~nm} \quad f=0.0445$

$3.0959 \mathrm{eV} \quad 400.48 \mathrm{~nm} \quad \mathrm{f}=0.0206$

$3.4193 \mathrm{eV} \quad 362.60 \mathrm{~nm} \quad \mathrm{f}=0.0238$

$3.4364 \mathrm{eV} \quad 360.80 \mathrm{~nm} \quad f=0.0874$

$3.5078 \mathrm{eV} \quad 353.45 \mathrm{~nm} \quad f=0.0421$

$3.5412 \mathrm{eV} \quad 350.12 \mathrm{~nm} \quad f=0.3662$ 


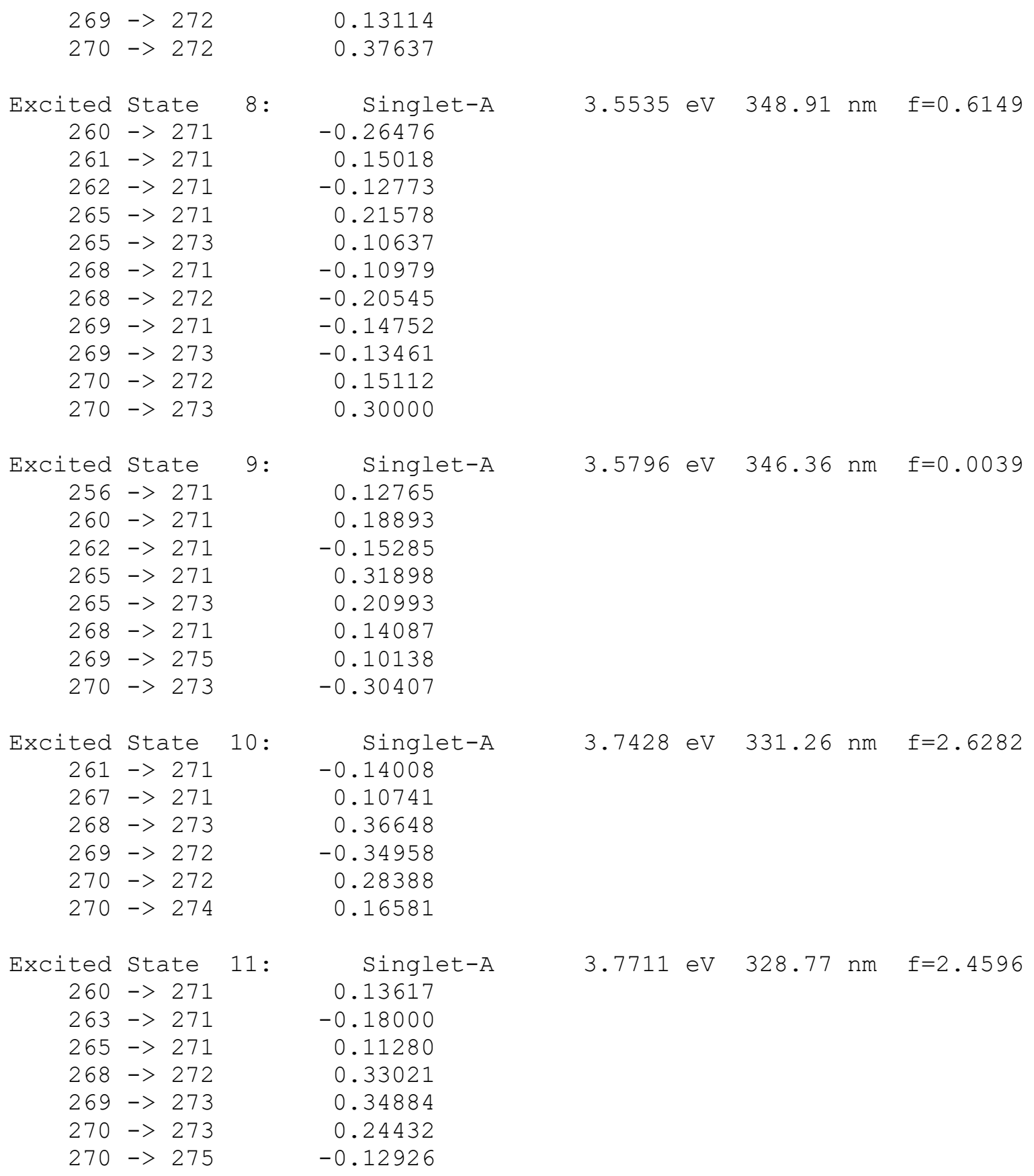

\section{TAA-Tips}

( $\mathrm{HOMO}=$ MO 288; LUMO = MO 289)

\begin{tabular}{|c|c|c|c|c|c|c|}
\hline $\begin{array}{r}\text { Excited } \\
286 \\
287 \\
288\end{array}$ & $\begin{array}{l}\text { State } \\
->291 \\
->290 \\
->289\end{array}$ & 1: & $\begin{array}{c}\text { Singlet-A } \\
0.24514 \\
-0.21951 \\
0.59973\end{array}$ & $2.7164 \mathrm{eV}$ & $456.43 \mathrm{~nm}$ & $f=0.0131$ \\
\hline $\begin{array}{r}\text { Excited } \\
286 \\
287 \\
287 \\
288 \\
288\end{array}$ & $\begin{array}{l}\text { State } \\
->289 \\
->289 \\
->290 \\
->290 \\
->291\end{array}$ & $2:$ & $\begin{aligned} & \text { Singlet-A } \\
&-0.22690 \\
& 0.56174 \\
&-0.13683 \\
&-0.19717 \\
&-0.17762\end{aligned}$ & $2.8424 \mathrm{eV}$ & $436.19 \mathrm{~nm}$ & $f=0.0597$ \\
\hline $\begin{array}{r}\text { Excited } \\
286\end{array}$ & $\begin{array}{l}\text { State } \\
->289\end{array}$ & $3:$ & $\begin{array}{l}\text { Singlet-A } \\
0.56112\end{array}$ & $2.8592 \mathrm{eV}$ & $433.64 \mathrm{~nm}$ & $f=0.0360$ \\
\hline
\end{tabular}




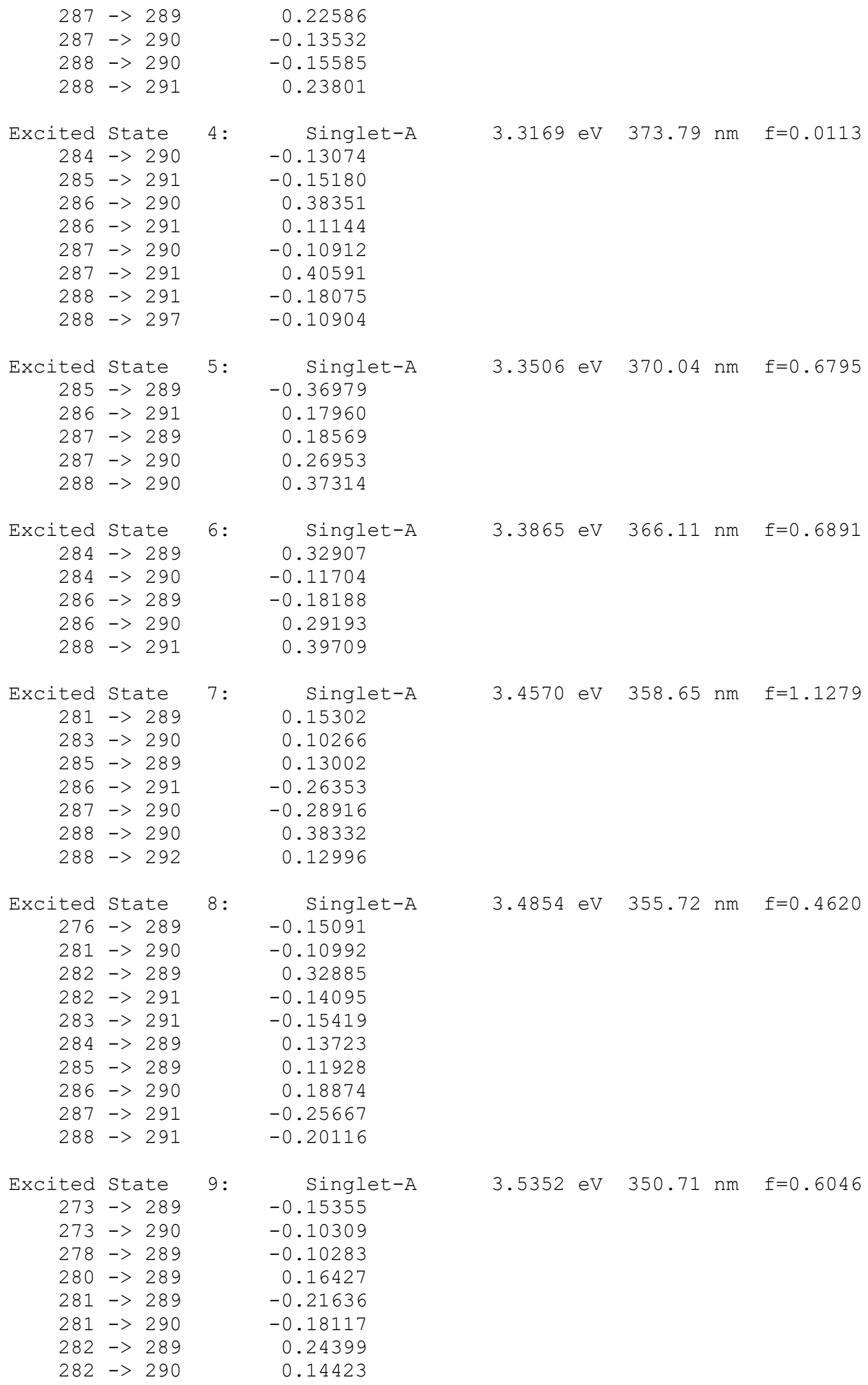




$\begin{array}{llr}283->289 & -0.20024 \\ 286->290 & -0.16584 \\ 287->291 & 0.24547 \\ 288->291 & 0.14542\end{array}$

Excited State 10:

$273->289$

$280->289$

$282->289$

$282->290$

$282->291$

$283->289$

$286->290$

$287->291$

$288->291$

Excited State 11:

$271->289$

$274->289$

$280->291$

$281->289$

$281->291$

$282->290$

$283->289$

$286->291$

$287->290$
Singlet-A

0.12780

$-0.20327$

0.16758

$-0.12923$

$-0.17486$

0.29091

$-0.22754$

0.25403

0.14370

Singlet-A

0.10661

0.12195

0.10484

0.38598

0.13756

$-0.11417$

$-0.13410$

0.22305

0.16256

$3.5772 \mathrm{eV} \quad 346.60 \mathrm{~nm} \quad f=0.7937$

$3.6360 \mathrm{eV} \quad 340.99 \mathrm{~nm} \quad \mathrm{f}=0.6576$

$2.9269 \mathrm{eV} \quad 423.61 \mathrm{~nm} \quad \mathrm{f}=0.0032$

Singlet-A

$-0.26963$

$-0.25810$

0.58414

$294->295$

\begin{tabular}{|c|c|c|c|}
\hline Excited & State & $2:$ & gle \\
\hline 292 & $->295$ & & -0.16707 \\
\hline 292 & $->296$ & & -0.12865 \\
\hline 293 & $->295$ & & 0.56460 \\
\hline 293 & -> 297 & & -0.11885 \\
\hline 294 & $->296$ & & -0.26940 \\
\hline
\end{tabular}

Excited State

$292->295$

3:

Singlet-A

0.56099

0.16197

$293->295$

$-0.16561$

$294->296$

$-0.12086$

$294->297$

$-0.27663$

Excited State

4:

Singlet-A

0.16465

$290->296$

0.13769

$291->297$

$-0.16927$

$292->296$

$-0.36822$

$293->297$

0.42621

$294->296$

0.11535

$294->307$

0.13166

$3.0439 \mathrm{eV} \quad 407.32 \mathrm{~nm} \quad \mathrm{f}=0.0315$

$3.0565 \mathrm{eV} \quad 405.65 \mathrm{~nm} \quad f=0.0363$

$3.4812 \mathrm{eV} \quad 356.16 \mathrm{~nm} \quad \mathrm{f}=0.0242$ 


\begin{tabular}{|c|c|c|c|c|c|c|c|c|}
\hline Excited & State & $5:$ & Singlet-A & 3.5151 & $\mathrm{eV}$ & 352.72 & $\mathrm{~nm}$ & $f=0.4461$ \\
\hline 286 & $->297$ & & 0.12860 & & & & & \\
\hline 290 & $->296$ & & -0.10245 & & & & & \\
\hline 291 & $->295$ & & -0.37550 & & & & & \\
\hline 291 & $->296$ & & -0.10014 & & & & & \\
\hline 292 & $->296$ & & 0.21658 & & & & & \\
\hline 293 & $->295$ & & 0.19837 & & & & & \\
\hline 294 & $->296$ & & 0.38871 & & & & & \\
\hline Excited & state & $6:$ & Singlet-A & 3.5417 & $\mathrm{eV}$ & 350.07 & $\mathrm{~nm}$ & $f=0.4491$ \\
\hline 286 & $->296$ & & -0.13331 & & & & & \\
\hline 290 & $->295$ & & -0.36730 & & & & & \\
\hline 290 & $->296$ & & 0.11950 & & & & & \\
\hline 292 & $->295$ & & 0.21005 & & & & & \\
\hline 292 & $->296$ & & -0.10446 & & & & & \\
\hline 293 & $->296$ & & 0.11469 & & & & & \\
\hline 294 & $->297$ & & 0.41521 & & & & & \\
\hline Excited & State & $7:$ & Singlet-A & 3.6847 & $\mathrm{eV}$ & 336.49 & $\mathrm{~nm}$ & $f=1.6076$ \\
\hline 288 & $->296$ & & 0.10402 & & & & & \\
\hline 288 & $->297$ & & 0.10847 & & & & & \\
\hline 289 & $->295$ & & 0.31925 & & & & & \\
\hline 289 & $->296$ & & 0.10880 & & & & & \\
\hline 291 & $->295$ & & 0.17915 & & & & & \\
\hline 292 & $->296$ & & -0.23123 & & & & & \\
\hline 292 & $->297$ & & 0.12158 & & & & & \\
\hline 293 & $->296$ & & -0.12108 & & & & & \\
\hline 293 & $->297$ & & -0.25715 & & & & & \\
\hline 294 & $->296$ & & 0.27839 & & & & & \\
\hline Excited & State & $8:$ & Singlet-A & 3.7237 & eV & 332.96 & $\mathrm{~nm}$ & $f=2.3040$ \\
\hline 288 & $->295$ & & 0.15324 & & & & & \\
\hline 289 & $->295$ & & 0.14230 & & & & & \\
\hline 289 & $->296$ & & 0.11694 & & & & & \\
\hline 290 & $->295$ & & -0.10921 & & & & & \\
\hline 292 & $->297$ & & -0.32625 & & & & & \\
\hline 293 & $->296$ & & 0.36740 & & & & & \\
\hline 293 & $->297$ & & -0.11448 & & & & & \\
\hline 294 & $->297$ & & -0.25620 & & & & & \\
\hline Excited & State & $9:$ & Singlet-A & 3.7414 & $\mathrm{eV}$ & 331.38 & $\mathrm{~nm}$ & $f=1.0557$ \\
\hline 287 & $->295$ & & 0.10386 & & & & & \\
\hline 287 & $->296$ & & -0.10647 & & & & & \\
\hline 288 & $->296$ & & 0.15522 & & & & & \\
\hline 289 & $->295$ & & 0.38836 & & & & & \\
\hline 289 & $->297$ & & 0.11806 & & & & & \\
\hline 290 & $->295$ & & 0.10120 & & & & & \\
\hline 292 & $->296$ & & 0.27106 & & & & & \\
\hline 293 & $->297$ & & 0.27302 & & & & & \\
\hline 294 & $->296$ & & -0.13546 & & & & & \\
\hline
\end{tabular}




\section{Ionization energies (IE), Electron affinities (AE)}

Table S-E.1a: Total electronic energies of the neutral and charged systems used to calculate the IP, EA and internal reorganization energies for holes and electrons. All values are given in atomic units and are issued from B3LYP/6-31G(d) calculations in the gas phase.

\begin{tabular}{|l|c|c|c|}
\hline compound & neutral (optimized) & anion (optimized) \\
\hline TAN-Ph & -1895.362357 & -1895.396003 \\
\hline TAN-MePh & -2013.315957 & -2013.348170 \\
\hline TAA-Ph & -2356.275805 & -2356.329814 \\
\hline TAA-Tips & -3825.225748 & -3825.294413 & -1895.114186 \\
\hline TAA-OMePh & -3386.940213 & -3386.996633 & -2356.050654 \\
\hline TAA-tBuPh & -3299.804369 & -3299.858166 & -3386.000768 \\
\hline
\end{tabular}

\begin{tabular}{|l|c|c|c|c|}
\hline compound & $\begin{array}{l}\text { anion (in the geometry of } \\
\text { the neutral compound) }\end{array}$ & $\begin{array}{l}\text { cation (in the geometry of } \\
\text { the neutral compound) }\end{array}$ & $\begin{array}{l}\text { neutral (in the geometry } \\
\text { of the anion) }\end{array}$ & $\begin{array}{l}\text { neutral (in the geometry } \\
\text { of the cation) }\end{array}$ \\
\hline TAN-Ph & -1895.394242 & -1895.110397 & -1895.360615 & -1895.35765 \\
\hline TAN-MePh & -2013.346423 & -2013.069302 & -2013.314078 & -2013.311643 \\
\hline TAA-Ph & -2356.328504 & -2356.049940 & -2356.274506 & -2356.273467 \\
\hline TAA-Tips & -3825.291814 & -3824.999355 & -3825.224374 & -3825.224270 \\
\hline TAA-OMePh & -3386.994908 & -3386.715321 & -3386.938495 & -3386.936612 \\
\hline TAA-tBuPh & -3299.857166 & -3299.581356 & -3299.802454 & -3299.803037 \\
\hline
\end{tabular}

Table S-E.1b: Ionization energies (IE), Electron affinities (AE) and Internal Reorganization Energies ( $\lambda \mathrm{i}$ ), for Hole (h) and Electron (e) Transport

\begin{tabular}{|l|l|l|l|l|}
\hline Compounds & IE $(\mathrm{eV})^{\mathrm{a}}$ & $\mathrm{EA}(\mathrm{eV})^{\mathrm{a}}$ & $\lambda_{\mathrm{h}}(\mathrm{eV})^{\mathrm{b}}$ & $\lambda_{\mathrm{e}}(\mathrm{eV})^{\mathrm{b}}$ \\
\hline TAN-Ph & 6.753 & 0.916 & 0.231 & 0.095 \\
\hline TAN-MePh & 6.613 & 0.877 & 0.216 & 0.099 \\
\hline TAA-Ph & 6.126 & 1.470 & 0.083 & 0.071 \\
\hline TAA-Tips & 6.122 & 1.868 & 0.079 & 0.108 \\
\hline TAA-OMePh & 6.049 & 1.535 & 0.168 & 0.094 \\
\hline TAA-tBuPh & 6.030 & 1.464 & 0.075 & 0.079 \\
\hline
\end{tabular}

a: calculated from differences in the total energies of the charged and neutral molecules in their optimized geometries. b: calculated using the four point adiabatic potential approach (see ESI section 5 for details). 


\section{Transfer integrals}

Table S-E.2. Transfer integrals (with absolute values larger than $2 \mathrm{meV}$ ) between a reference molecule (i) and its first neighbors (j), calculated for holes (h) and electrons (e) at the B3LYP/6-31G(d) level.

\begin{tabular}{|c|c|c|c|c|c|}
\hline Compound & Direction $^{a}$ & $\mathrm{~d}_{\mathrm{i}-\mathrm{j}}(\AA)^{\mathrm{b}}$ & $J_{h}(m e V)^{c}$ & $\mathrm{~J}_{\mathrm{e}}(\mathrm{meV})^{\mathrm{c}}$ & $\begin{array}{c}\text { Dimer } \\
\text { relation }^{\mathrm{d}}\end{array}$ \\
\hline $\begin{array}{l}\text { TAN-Ph } \\
\text { P̄ }\end{array}$ & $\begin{array}{l}(0.52,0.02,0.13) \\
(-0.48,0.02,0.13) \\
(-0.52,-1.02 ;-0.12) \\
\pm(0,0,1) \\
(-0.52,-1.02,-1.13) \\
\pm(1,1,0) \\
\pm(1,1,1)\end{array}$ & \begin{tabular}{l|}
5.853 \\
6.075 \\
10.888 \\
13.640 \\
13.721 \\
13.777 \\
13.748 \\
\end{tabular} & $\begin{array}{l}12(68) \\
15(24) \\
0 \\
7(10) \\
1(4) \\
1(9) \\
7(6) \\
\end{array}$ & $\begin{array}{l}67 \\
5 \\
2 \\
5 \\
2 \\
2 \\
2 \\
\end{array}$ & $\begin{array}{l}\overline{1} \\
\frac{1}{1} \\
\frac{1}{1} \\
1 \\
1\end{array}$ \\
\hline 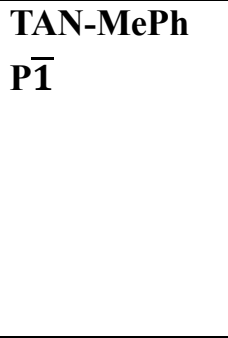 & $\begin{array}{l}(0.02,0.03,0.46) \\
(0.02,0.03,-0.53) \\
(0.02,-0.96,-0,53) \\
(0.02,1.03,0.46) \\
(1.02,0.03,-0.53) \\
\pm(1,1,0) \\
(1.02,1.03,0.46)\end{array}$ & $\begin{array}{l}6.162 \\
7.272 \\
12.952 \\
13.181 \\
13.812 \\
13.907 \\
14.540 \\
\end{array}$ & $\begin{array}{l}15 \\
15 \\
8 \\
7 \\
13 \\
0 \\
6 \\
\end{array}$ & $\begin{array}{l}3 \\
47 \\
3 \\
14 \\
1 \\
6 \\
1\end{array}$ & $\begin{array}{l}\frac{\overline{1}}{1} \\
\frac{1}{1} \\
\frac{1}{1} \\
\frac{1}{1}\end{array}$ \\
\hline $\begin{array}{l}\text { TAA-Ph } \\
\text { R3 }\end{array}$ & $\begin{array}{l}(0,0,-0.45) \\
(0,0,0.55) \\
(-2 / 3,-1 / 3,0.22) \\
(1 / 3,2 / 3,0.22) \\
(1 / 3,-1 / 3,0.22) \\
\pm(-1 / 3,1 / 3,1 / 3) \\
\pm(-1 / 3,-2 / 3,1 / 3) \\
\pm(2 / 3,1 / 3,1 / 3) \\
\end{array}$ & \begin{tabular}{l|}
4.194 \\
5.177 \\
15.660 \\
15.660 \\
15.660 \\
15.836 \\
15.836 \\
15.836 \\
\end{tabular} & $\begin{array}{l}39 \\
8 \\
0 \\
0 \\
0 \\
10 \\
10 \\
10 \\
\end{array}$ & $\begin{array}{l}72 \\
8 \\
12 \\
12 \\
12 \\
6 \\
6 \\
6 \\
\end{array}$ & $\begin{array}{c}A \rightarrow B \\
A \rightarrow B \\
A \rightarrow B \\
A \rightarrow B \\
A \rightarrow B \\
1 \\
1 \\
1\end{array}$ \\
\hline $\begin{array}{l}\text { TAA-Tips } \\
\text { P2 } 1 / \text { n }\end{array}$ & $\begin{array}{l}(0.09,0.22,-0.22) \\
(-0.41, \pm 1 / 2,0.28) \\
(0.09,1.22,-0.22) \\
(0.59, \pm 1 / 2,0.28) \\
\end{array}$ & $\begin{array}{l}7.881 \\
13.131 \\
14.792 \\
15.036 \\
\end{array}$ & $\begin{array}{l}7 \\
0 \\
2 \\
3 \\
\end{array}$ & $\begin{array}{l}90 \\
2 \\
9 \\
2 \\
\end{array}$ & $\begin{array}{c}\overline{1} \\
2_{1} \\
\overline{1} \\
2 / 1 \\
\end{array}$ \\
\hline $\begin{array}{l}\text { TAA-OMePh } \\
\text { P' }\end{array}$ & $\begin{array}{l}(-0.43,0.61,-1 / 3) \\
(0.57,-0.39,-1 / 3) \\
-(0.43,-0.39,-1 / 3) \\
(-0.43,-0.39,2 / 3) \\
(0.57,0.61,-1 / 3) \\
\pm(0,1,0) \\
\pm(0,0,1) \\
\pm(0,-1,1)\end{array}$ & $\begin{array}{l}9.522 \\
10.464 \\
11.771 \\
11.933 \\
12.150 \\
15.712 \\
16.961 \\
18.432 \\
\end{array}$ & $\begin{array}{l}23 \\
39 \\
2 \\
7 \\
1 \\
5 \\
4 \\
3\end{array}$ & $\begin{array}{l}85 \\
85 \\
1 \\
41 \\
1 \\
3 \\
7 \\
0\end{array}$ & $\begin{array}{l}\frac{\overline{1}}{1} \\
\frac{1}{1} \\
\overline{1} \\
1 \\
1 \\
1\end{array}$ \\
\hline 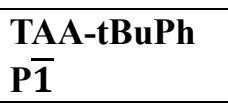 & $(-0.46,-0.96,-0.94)$ & 15.902 & 3 & 3 & $\overline{1}$ \\
\hline
\end{tabular}

${ }^{a}$ Crystallographic directions corresponding to intermolecular vectors joining one central molecule with its neighbours are given in the basis of direct lattice vectors. ${ }^{b} \mathrm{~d}_{\mathrm{i}-\mathrm{j}}$ is the distance (in $\AA$ ) between the centers of mass of molecules $\mathrm{i}$ and $\mathrm{j}$. ${ }^{\mathrm{c}}$ values in parentheses are calculated using equation SI5 accounting for the close degeneracy of the two highest occupied MOs. ${ }^{d}$ Symmetry relationship linking molecules $i$ and $j$. When $i$ and $j$ possess identical geometry, symmetry operations are given, otherwise dimers are described as $\mathrm{A} \rightarrow \mathrm{B}$. $\mathrm{B} \rightarrow \mathrm{B}$ dimers do not have close contacts, so that all integral transfers for those dimers are negligible. 

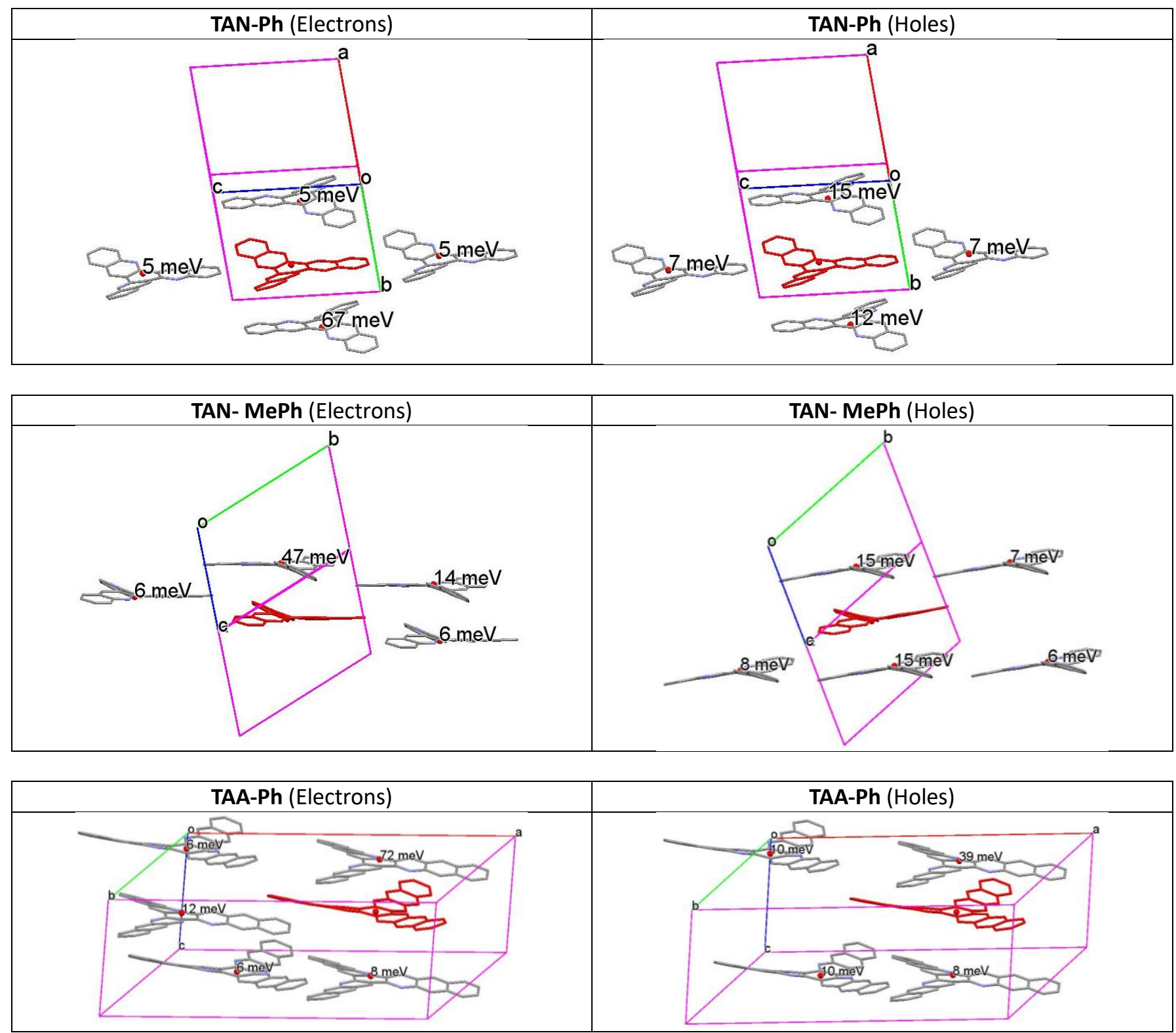

Figure S-E.10. Molecular packing within the investigated crystals, with values of the main electron and hole transfer integrals between the reference molecule (in red) and its first neighbors for TAN-Ph, TAN-PhMe an TAA-Ph. Lattice vectors a, $\mathrm{b}$ and $\mathrm{c}$ are represented in red, green and blue, respectively. In all structures, lateral substituents and hydrogen atoms have been omitted for clarity. 


TAA-Tips (Electrons)
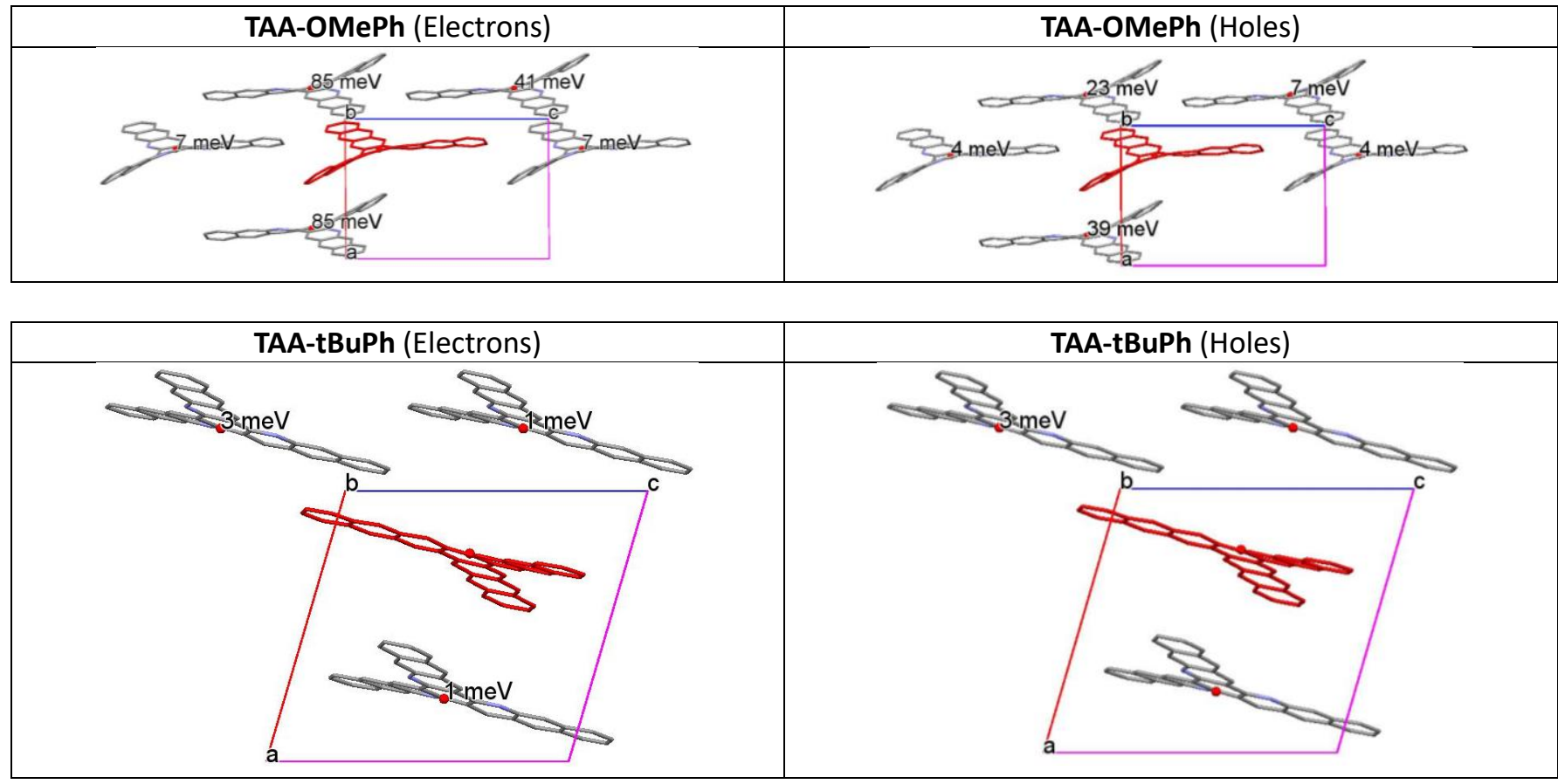

Figure S-E.11. Molecular packing within the investigated crystals, with values of the main electron and hole transfer integrals between the reference molecule (in red) and its first neighbors for TAA-Tips, TAA-OMePh and TAAtBuPh. Lattice vectors $\mathrm{a}, \mathrm{b}$ and $\mathrm{c}$ are represented in red, green and blue, respectively. In all structures, lateral substituents and hydrogen atoms have been omitted for clarity. 


\section{Molecular structures}

\section{TAN-Ph}

No imaginary frequency

Energies (in atomic units):

Electronic energy $=-1895.36235747$

Zero-point correction=

Thermal correction to Energy=

Thermal correction to Enthalpy=

Thermal correction to Gibbs Free Energy=

Sum of electronic and zero-point Energies=

Sum of electronic and thermal Energies=

Sum of electronic and thermal Enthalpies=

Sum of electronic and thermal Free Energies=

Cartesian coordinates (in Angströms):

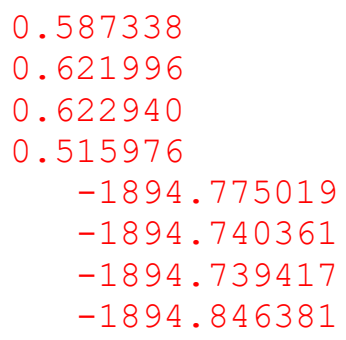

0.00232200

0.40521500

$-0.46378500$

$-0.00541100$

$-0.06168400$

0.36423700

0.10903700

$-0.22675400$

$-0.01833000$

0.13360600

$-0.13436200$

$-0.00196400$

$-0.16437000$

$-0.51050900$

0.01186100

0.51754200

$-0.18899700$

$-0.30692000$

0.02054800

0.01752500

0.49775100

0.38554400

0.74236600

1.71692500

0.31199600

$-0.81482700$

$-1.02500900$

$-0.29661100$

$-0.39624900$

$-0.29893000$

$-0.39903000$

$-0.05801400$

0.02968100

0.54956200

1.37600000

$-0.81430600$

$-1.04102500$

1.63903200

2.43859600

0.76548400

0.86227900 


$\begin{array}{lrrr}\mathrm{C} & -0.32373400 & 4.60848000 & -1.19173700 \\ \mathrm{H} & 0.16677000 & 4.23573200 & -2.08673900 \\ \mathrm{C} & -1.58358900 & 5.56321100 & 1.10398400 \\ \mathrm{H} & -2.06568500 & 5.93432400 & 2.00478500 \\ \mathrm{C} & 0.62191800 & -6.07089700 & -0.16847300 \\ \mathrm{H} & 0.26492400 & -7.09737600 & -0.16599500 \\ \mathrm{C} & 4.41829200 & 2.21726600 & 0.79738000 \\ \mathrm{H} & 5.07705500 & 1.36082000 & 0.89967400 \\ \mathrm{C} & 4.87024100 & 3.50946200 & 0.91677100 \\ \mathrm{H} & 5.91859100 & 3.70495300 & 1.12611900 \\ \mathrm{C} & -5.99041200 & 1.15986600 & -0.50371400 \\ \mathrm{H} & -7.06382000 & 0.99102500 & -0.49188300 \\ \mathrm{C} & -4.44805600 & -4.11025900 & -0.41123500 \\ \mathrm{H} & -4.84666300 & -4.72399000 & -1.21512900 \\ \mathrm{C} & -5.13461500 & 0.12182000 & -0.21391400 \\ \mathrm{H} & -5.53163400 & -0.85831800 & 0.02211100 \\ \mathrm{C} & -3.86272700 & -2.87971100 & -0.70806300 \\ \mathrm{H} & -3.79955200 & -2.54233000 & -1.73895300 \\ \mathrm{C} & -1.11858600 & 5.75240200 & -1.25628300 \\ \mathrm{H} & -1.23635700 & 6.27260900 & -2.20356200 \\ \mathrm{C} & 3.99502000 & -1.44149800 & -1.56284100 \\ \mathrm{H} & 3.30758300 & -1.27670600 & -2.38819600 \\ \mathrm{C} & -0.78562800 & 4.42074400 & 1.16927700 \\ \mathrm{H} & -0.65144300 & 3.90520400 & 2.11643500 \\ \mathrm{C} & -4.02532700 & -3.74489800 & 1.93635500 \\ \mathrm{H} & -4.09414500 & -4.07187300 & 2.97073500 \\ \mathrm{C} & -1.75711900 & 6.23152800 & -0.10951900 \\ \mathrm{H} & -2.37461400 & 7.12449200 & -0.15939700 \\ \mathrm{C} & 6.25544800 & -1.49404100 & -0.69995200 \\ \mathrm{H} & 7.32480300 & -1.37255600 & -0.85103800 \\ \mathrm{C} & -4.52810900 & -4.55031800 & 0.91229300 \\ \mathrm{H} & -4.98883600 & -5.50692700 & 1.14426300 \\ \mathrm{C} & 5.36744500 & -1.28212900 & -1.75590000 \\ \mathrm{H} & 5.74281900 & -0.99617200 & -2.73510800\end{array}$

\section{TAN-MePh}

No imaginary frequency

Energies (in atomic units):

Electronic energy $=-2013.31595666$

Zero-point correction $=0.669843$ (Hartree/Particle)

Thermal correction to Energy=

0.710247

Thermal correction to Enthalpy=

0.711191

Thermal correction to Gibbs Free Energy=

Sum of electronic and zero-point Energies=

Sum of electronic and thermal Energies=

Sum of electronic and thermal Enthalpies=

Sum of electronic and thermal Free Energies=

Cartesian coordinates (in Angströms):

$\begin{array}{lrrr}\mathrm{N} & -1.13398800 & 2.43813200 & -0.52801900 \\ \mathrm{~N} & 2.68358100 & -0.28489000 & 0.55992100 \\ \mathrm{~N} & -1.59556900 & -2.30602400 & -0.14376900 \\ \mathrm{C} & -0.80807200 & -1.24980300 & -0.04824600 \\ \mathrm{C} & 3.00760100 & 2.12543600 & 0.52978100 \\ \mathrm{C} & -0.63858200 & 1.25192100 & -0.22741700 \\ \mathrm{C} & 1.20748800 & -2.62170100 & -0.15024400 \\ \mathrm{C} & 0.62768700 & -1.35177300 & -0.00546500\end{array}$




\begin{tabular}{|c|c|c|c|}
\hline $\mathrm{C}$ & 0.81909500 & 1.17473400 & 0.02399900 \\
\hline $\mathrm{C}$ & 1.63239900 & 2.30778200 & 0.18458000 \\
\hline C & 1.42364700 & -0.12120900 & 0.19904200 \\
\hline $\mathrm{C}$ & 3.48117000 & 0.79190600 & 0.72551900 \\
\hline $\mathrm{C}$ & -1.46357700 & 0.07844200 & -0.08006700 \\
\hline $\mathrm{C}$ & 1.16910700 & 3.72793100 & 0.05555800 \\
\hline $\mathrm{C}$ & -3.39064800 & 1.55154300 & -0.33653000 \\
\hline $\mathrm{C}$ & -3.84400500 & -0.83272100 & 0.23177000 \\
\hline $\mathrm{C}$ & -1.06086500 & -3.54307300 & -0.21963200 \\
\hline $\mathrm{C}$ & 2.67969600 & -2.87323200 & -0.26745100 \\
\hline $\mathrm{C}$ & -2.47079100 & 2.60910000 & -0.61536400 \\
\hline $\mathrm{C}$ & 0.70609300 & 4.42996200 & 1.17481100 \\
\hline $\mathrm{H}$ & 0.60722100 & 3.91553800 & 2.12702500 \\
\hline $\mathrm{C}$ & -2.85720400 & 0.25100400 & -0.07472000 \\
\hline $\mathrm{C}$ & 0.35108200 & -3.76110900 & -0.25616900 \\
\hline $\mathrm{C}$ & 1.30614000 & 4.41938800 & -1.15417800 \\
\hline $\mathrm{H}$ & 1.67338900 & 3.89470000 & -2.03200800 \\
\hline $\mathrm{C}$ & 4.83401700 & 0.56740400 & 1.10382400 \\
\hline $\mathrm{H}$ & 5.15114600 & -0.46201200 & 1.23687000 \\
\hline $\mathrm{C}$ & 3.40680000 & -3.43925400 & 0.78725200 \\
\hline $\mathrm{H}$ & 2.91298600 & -3.62803200 & 1.73656800 \\
\hline $\mathrm{C}$ & -2.95675400 & 3.90302800 & -0.95102300 \\
\hline $\mathrm{H}$ & -2.22211800 & 4.67476400 & -1.15788400 \\
\hline $\mathrm{C}$ & 5.43037700 & -3.49378300 & -0.56776000 \\
\hline $\mathrm{C}$ & -5.81483800 & -2.77173500 & 0.86157400 \\
\hline $\mathrm{C}$ & 3.33867800 & -2.64570500 & -1.48185900 \\
\hline $\mathrm{H}$ & 2.78955500 & -2.21936500 & -2.31724500 \\
\hline $\mathrm{C}$ & -4.64944100 & -1.38844100 & -0.76990500 \\
\hline $\mathrm{H}$ & -4.50612800 & -1.08306300 & -1.80281900 \\
\hline $\mathrm{C}$ & -4.05511400 & -1.23824600 & 1.55565800 \\
\hline $\mathrm{H}$ & -3.44829200 & -0.81049400 & 2.34924600 \\
\hline $\mathrm{C}$ & 3.92524900 & 3.19999900 & 0.71596200 \\
\hline $\mathrm{H}$ & 3.58442700 & 4.21813100 & 0.56969000 \\
\hline C & 5.23015800 & 2.95455000 & 1.07748400 \\
\hline $\mathrm{H}$ & 5.91619000 & 3.78625000 & 1.21369800 \\
\hline $\mathrm{C}$ & 0.82176500 & -5.09766600 & -0.40892100 \\
\hline $\mathrm{H}$ & 1.88855000 & -5.28075000 & -0.45965300 \\
\hline $\mathrm{C}$ & 5.69090300 & 1.62806700 & 1.27465000 \\
\hline $\mathrm{H}$ & 6.72552100 & 1.45515000 & 1.55896000 \\
\hline $\mathrm{C}$ & -0.06223300 & -6.14948000 & -0.48587100 \\
\hline $\mathrm{H}$ & 0.31528500 & -7.16232000 & -0.59793300 \\
\hline $\mathrm{C}$ & 4.76074500 & -3.73524800 & 0.63961200 \\
\hline $\mathrm{H}$ & 5.30684400 & -4.16397700 & 1.47753500 \\
\hline $\mathrm{C}$ & -4.30870000 & 4.14857400 & -0.98172500 \\
\hline $\mathrm{H}$ & -4.67906700 & 5.13916500 & -1.23220100 \\
\hline $\mathrm{C}$ & -4.78386300 & 1.85128400 & -0.35130700 \\
\hline $\mathrm{H}$ & -5.49634900 & 1.07007800 & -0.11441700 \\
\hline $\mathrm{C}$ & 0.46618200 & 6.46754300 & -0.13749900 \\
\hline $\mathrm{C}$ & -1.46131500 & -5.92699500 & -0.42402600 \\
\hline $\mathrm{H}$ & -2.14295600 & -6.77135200 & -0.48419100 \\
\hline $\mathrm{C}$ & -5.02032400 & -2.19522300 & 1.86149700 \\
\hline $\mathrm{H}$ & -5.15975200 & -2.49914200 & 2.89694600 \\
\hline $\mathrm{C}$ & 0.35036800 & 5.77416000 & 1.07401600 \\
\hline $\mathrm{H}$ & -0.02007900 & 6.29442000 & 1.95493500 \\
\hline $\mathrm{C}$ & 4.69266300 & -2.94462400 & -1.62405500 \\
\hline $\mathrm{H}$ & 5.18391100 & -2.74964000 & -2.57513700 \\
\hline C & -5.60999800 & -2.34964200 & -0.45882400 \\
\hline $\mathrm{H}$ & -6.21390900 & -2.77705200 & -1.25673700 \\
\hline $\mathrm{C}$ & -5.22734900 & 3.11460700 & -0.67000000 \\
\hline
\end{tabular}




$\begin{array}{lrrr}\text { H } & -6.29370700 & 3.32367700 & -0.67988600 \\ \mathrm{C} & 0.95298000 & 5.76423600 & -1.24800500 \\ \mathrm{H} & 1.05939200 & 6.27773100 & -2.20148500 \\ \mathrm{C} & -1.95199500 & -4.64960200 & -0.29871900 \\ \mathrm{H} & -3.01583900 & -4.43776000 & -0.25980300 \\ \mathrm{C} & 0.11609100 & 7.93475400 & -0.23413900 \\ \mathrm{H} & 0.97990700 & 8.56977200 & 0.00561600 \\ \mathrm{H} & -0.68489100 & 8.20296700 & 0.46336200 \\ \mathrm{H} & -0.21158100 & 8.20359700 & -1.24423800 \\ \mathrm{C} & 6.88995200 & -3.84765900 & -0.73650800 \\ \mathrm{H} & 7.42246800 & -3.82120300 & 0.22029800 \\ \mathrm{H} & 7.39341900 & -3.15757700 & -1.42241600 \\ \mathrm{H} & 7.01227400 & -4.85894400 & -1.14785700 \\ \mathrm{C} & -6.88237300 & -3.78599600 & 1.20194700 \\ \mathrm{H} & -6.58369200 & -4.41466500 & 2.04804900 \\ \mathrm{H} & -7.09710300 & -4.44297000 & 0.35228300 \\ \mathrm{H} & -7.82573300 & -3.29677300 & 1.48046600\end{array}$

\section{TAA-Ph}

No imaginary frequency

Energies (in atomic units):

Electronic energy $=-2356.27580455$

Zero-point correction $=0.727021$ (Hartree/Particle)

Thermal correction to Energy=

0.769949

Thermal correction to Enthalpy=

0.770894

Thermal correction to Gibbs Free Energy=

Sum of electronic and zero-point Energies=

0.646359

Sum of electronic and thermal Energies=

Sum of electronic and thermal Enthalpies= $-2355.548783$

$-2355.505855$

$-2355.504911$

Sum of electronic and thermal Free Energies= $-2355.629446$

Cartesian coordinates (in Angströms):

$\begin{array}{lrrr}\text { N } & 2.30247100 & -1.57376500 & 0.11718500 \\ \mathrm{C} & 3.54902000 & -1.04378100 & 0.00475600 \\ \mathrm{C} & 3.75778500 & 0.36407400 & -0.21046000 \\ \mathrm{C} & 2.59876900 & 1.21711700 & -0.23096500 \\ \mathrm{C} & 2.83934400 & 2.66654300 & -0.52249900 \\ \mathrm{C} & 2.61369800 & 3.16694200 & -1.81139400 \\ \mathrm{H} & 2.20070100 & 2.51184900 & -2.57374500 \\ \mathrm{C} & 2.90382900 & 4.49695500 & -2.11719200 \\ \mathrm{H} & 2.71665900 & 4.87079800 & -3.12051200 \\ \mathrm{C} & 3.43666200 & 5.34226600 & -1.14281800 \\ \mathrm{H} & 3.66491200 & 6.37760400 & -1.38175800 \\ \mathrm{C} & 3.68477600 & 4.84463400 & 0.13912300 \\ \mathrm{H} & 4.10831500 & 5.49198000 & 0.90299600 \\ \mathrm{C} & 3.39537500 & 3.51531900 & 0.44481700 \\ \mathrm{H} & 3.58332900 & 3.13370200 & 1.44450800 \\ \mathrm{C} & 1.33918400 & 0.64919400 & -0.03773800 \\ \mathrm{C} & 1.24672400 & -0.79285400 & 0.08958000 \\ \mathrm{C} & 5.07075400 & 0.82542600 & -0.39297800 \\ \mathrm{H} & 5.24877400 & 1.87921400 & -0.57664700 \\ \mathrm{C} & 6.16929000 & -0.04200000 & -0.33514400 \\ \mathrm{C} & 5.95313500 & -1.44997300 & -0.09106700 \\ \mathrm{C} & 4.64425900 & -1.91603700 & 0.06647300 \\ \mathrm{H} & 4.44351300 & -2.96999400 & 0.23551700 \\ \mathrm{C} & 7.08835400 & -2.31777200 & -0.03097900 \\ \mathrm{H} & 6.92188300 & -3.37615700 & 0.15355600 \\ \mathrm{C} & 8.35636900 & -1.82857800 & -0.20254100\end{array}$




\begin{tabular}{|c|c|c|c|}
\hline $\mathrm{H}$ & 9.21056200 & -2.49862800 & -0.15450900 \\
\hline C & 8.57028600 & -0.43927600 & -0.44604400 \\
\hline $\mathrm{H}$ & 9.58375400 & -0.07109700 & -0.58022500 \\
\hline & 7.50945600 & 0.42517500 & -0.51035500 \\
\hline $\mathrm{H}$ & 7.66863500 & 1.48479900 & -0.69529900 \\
\hline & -2.42056800 & -1.18580000 & -0.49604300 \\
\hline & -2.59206600 & -2.53395200 & -0.44062400 \\
\hline & -1.54029300 & -3.41149400 & 0.00182600 \\
\hline & -0.24646900 & -2.83279900 & 0.25496100 \\
\hline 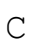 & 0.82815400 & -3.77003300 & 0.71136800 \\
\hline C & 1.41723000 & -4.68080400 & -0.17649600 \\
\hline $\mathrm{H}$ & 1.14091300 & -4.65696300 & -1.22693500 \\
\hline & 2.36962600 & -5.59447000 & 0.27398900 \\
\hline & 2.82560700 & -6.28657500 & -0.42951600 \\
\hline & 2.73222600 & -5.62535600 & 1.62290400 \\
\hline $\mathrm{H}$ & 3.47045100 & -6.34105600 & 1.97506100 \\
\hline C & 2.12900400 & -4.73938500 & 2.51784500 \\
\hline $\mathrm{H}$ & 2.39506300 & -4.76318800 & 3.57148400 \\
\hline$c$ & 1.18063900 & -3.82197700 & 2.06645200 \\
\hline $\mathrm{H}$ & 0.71611300 & -3.13169400 & 2.76530900 \\
\hline$C$ & -0.07944800 & -1.45614500 & 0.09466000 \\
\hline C & -1.25759600 & -0.65660600 & -0.19491300 \\
\hline C & -1.82442800 & -4.77909800 & 0.13878400 \\
\hline $\mathrm{H}$ & -1.05461100 & -5.45440600 & 0.49536800 \\
\hline 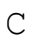 & -3.08211700 & -5.30451100 & -0.18587700 \\
\hline $\mathrm{C}$ & -4.12064100 & -4.42173400 & -0.66589800 \\
\hline $\mathrm{C}$ & -3.84879400 & -3.05408000 & -0.77558100 \\
\hline $\mathrm{H}$ & -4.61573200 & -2.35723800 & -1.10080400 \\
\hline c & -5.39585800 & -4.97853600 & -0.99532300 \\
\hline $\mathrm{H}$ & -6.17484000 & -4.31123500 & -1.35564300 \\
\hline C & -5.63241100 & -6.32120000 & -0.85985100 \\
\hline 4 & -6.60583100 & -6.73183700 & -1.11432300 \\
\hline $\mathrm{C}$ & -4.60835000 & -7.19292700 & -0.38433500 \\
\hline $\mathrm{H}$ & -4.81599100 & -8.25468700 & -0.28319200 \\
\hline $\mathrm{C}$ & -3.37310300 & -6.69860100 & -0.05741400 \\
\hline $\mathrm{H}$ & -2.58985500 & -7.36004600 & 0.30503700 \\
\hline $\mathrm{N}$ & 0.25063100 & 2.73774700 & 0.30068400 \\
\hline $\mathrm{C}$ & -0.83811200 & 3.54988500 & 0.36299300 \\
\hline $\mathrm{C}$ & -2.17251800 & 3.04249400 & 0.18358400 \\
\hline $\mathrm{C}$ & -2.33220600 & 1.62784200 & -0.02922600 \\
\hline C & -3.74511200 & 1.13853000 & -0.13644500 \\
\hline $\mathrm{C}$ & -4.41704600 & 1.16793800 & -1.36569800 \\
\hline $\mathrm{H}$ & -3.87958200 & 1.46900200 & -2.26065900 \\
\hline $\mathrm{C}$ & -5.75825500 & 0.79550600 & -1.44852600 \\
\hline $\mathrm{H}$ & -6.26394500 & 0.81767400 & -2.41062700 \\
\hline $\mathrm{C}$ & -6.45103100 & 0.39966700 & -0.30140200 \\
\hline $\mathrm{H}$ & -7.49692500 & 0.11123800 & -0.36572500 \\
\hline $\mathrm{C}$ & -5.79387900 & 0.39132900 & 0.93031400 \\
\hline $\mathrm{H}$ & -6.32641400 & 0.09601400 & 1.83070700 \\
\hline $\mathrm{C}$ & -4.45335800 & 0.76873700 & 1.01421400 \\
\hline $\mathrm{H}$ & -3.94670100 & 0.76412700 & 1.97552600 \\
\hline C & -1.19545600 & 0.82019600 & -0.08564500 \\
\hline $\mathrm{C}$ & 0.10094900 & 1.45515900 & 0.06085500 \\
\hline $\mathrm{C}$ & -3.24635800 & 3.94386500 & 0.25209300 \\
\hline $\mathrm{H}$ & -4.25985000 & 3.58179600 & 0.11918500 \\
\hline $\mathrm{C}$ & -3.04502800 & 5.30981500 & 0.48901000 \\
\hline $\mathrm{C}$ & -1.70169400 & 5.81091800 & 0.67081300 \\
\hline $\mathrm{C}$ & -0.63062800 & 4.91430400 & 0.60462800 \\
\hline $\mathrm{H}$ & 0.39254500 & 5.25713100 & 0.72710600 \\
\hline
\end{tabular}




$\begin{array}{llll}\mathrm{C} & -1.51766300 & 7.20878000 & 0.91018700 \\ \mathrm{H} & -0.50565200 & 7.58225000 & 1.04546800 \\ \mathrm{C} & -2.59046500 & 8.05872700 & 0.96820600 \\ \mathrm{H} & -2.43706400 & 9.11885900 & 1.15123700 \\ \mathrm{C} & -3.91681600 & 7.56464900 & 0.78988600 \\ \mathrm{H} & -4.75440000 & 8.25504400 & 0.83975000 \\ \mathrm{C} & -4.13553800 & 6.23237900 & 0.55753100 \\ \mathrm{H} & -5.14502700 & 5.85212500 & 0.42096200\end{array}$

\section{TAA-tBuPh}

No imaginary frequency

Energies (in atomic units):

Electronic energy $=-3299.80437280$

Zero-point correction=

Thermal correction to Energy=

Thermal correction to Enthalpy=

Thermal correction to Gibbs Free Energy=

Sum of electronic and zero-point Energies=

Sum of electronic and thermal Energies=

Sum of electronic and thermal Enthalpies=

Sum of electronic and thermal Free Energies=

Cartesian coordinates (in Angströms):

$\begin{array}{lrrr}\mathrm{N} & -1.72456500 & 2.04623700 & 0.59100500 \\ \mathrm{~N} & 2.75247900 & 0.58377400 & -0.25699900 \\ \mathrm{~N} & -0.82759200 & -2.56993500 & -0.43894800 \\ \mathrm{C} & -3.05266100 & 1.81641600 & 0.76914000 \\ \mathrm{C} & -3.86289100 & 2.89224500 & 1.15596700 \\ \mathrm{H} & -3.38705100 & 3.85814000 & 1.29813400 \\ \mathrm{C} & -5.24103000 & 2.73577300 & 1.33576200 \\ \mathrm{C} & -6.09169000 & 3.81726100 & 1.72567700 \\ \mathrm{H} & -5.64475200 & 4.79481200 & 1.88941200 \\ \mathrm{C} & -7.43844600 & 3.62798400 & 1.89059400 \\ \mathrm{H} & -8.07345800 & 4.45819600 & 2.18802000 \\ \mathrm{C} & -8.02134500 & 2.34391900 & 1.67501800 \\ \mathrm{H} & -9.09157200 & 2.21424500 & 1.81098800 \\ \mathrm{C} & -7.24101300 & 1.28225400 & 1.29978100 \\ \mathrm{H} & -7.68161300 & 0.30200000 & 1.13440900 \\ \mathrm{C} & -5.83093900 & 1.43466100 & 1.11661000 \\ \mathrm{C} & -5.01497600 & 0.36239600 & 0.73323600 \\ \mathrm{H} & -5.46971100 & -0.60896700 & 0.57305600 \\ \mathrm{C} & -3.63131700 & 0.51718300 & 0.55436000 \\ \mathrm{C} & -2.74988200 & -0.56281600 & 0.19534200 \\ \mathrm{C} & -1.38737400 & -0.29947600 & 0.03943100 \\ \mathrm{C} & -0.93331700 & 1.06901000 & 0.21169400 \\ \mathrm{C} & 1.46790300 & 0.35815600 & -0.10011600 \\ \mathrm{C} & 0.48291300 & 1.42142600 & -0.04267100 \\ \mathrm{C} & 0.91489900 & 2.73543300 & -0.23108400 \\ \mathrm{C} & 2.32167800 & 2.98632300 & -0.40576800 \\ \mathrm{C} & 2.86772300 & 4.26355700 & -0.60810700 \\ \mathrm{H} & 2.21154800 & 5.12571800 & -0.65100300 \\ \mathrm{C} & 4.24768500 & 4.45977200 & -0.74911800 \\ \mathrm{C} & 4.80886600 & 5.76035700 & -0.94576300 \\ \mathrm{H} & 4.13617300 & 6.61362400 & -0.98802300 \\ \mathrm{C} & 6.16183700 & 5.93114600 & -1.07645600 \\ \mathrm{H} & 6.57522100 & 6.92506200 & -1.22458800 \\ \mathrm{C} & 7.04039000 & 4.80857000 & -1.01939300\end{array}$




\begin{tabular}{|c|c|c|c|}
\hline $\mathrm{H}$ & 8.11075000 & 4.96394200 & -1.12500500 \\
\hline $\mathrm{C}$ & 6.54408800 & 3.54523800 & -0.83434900 \\
\hline $\mathrm{H}$ & 7.21101000 & 2.68757300 & -0.79211100 \\
\hline $\mathrm{C}$ & 5.13822400 & 3.32280600 & -0.69416100 \\
\hline $\mathrm{C}$ & 4.59457700 & 2.04680100 & -0.51710900 \\
\hline $\mathrm{H}$ & 5.23166500 & 1.16775300 & -0.48265400 \\
\hline $\mathrm{C}$ & 3.21254100 & 1.85644700 & -0.38116700 \\
\hline $\mathrm{C}$ & -0.37823600 & -1.36136400 & -0.19195900 \\
\hline $\mathrm{C}$ & 1.03773100 & -1.06022200 & -0.06539700 \\
\hline $\mathrm{C}$ & 1.93422400 & -2.12943400 & -0.01332100 \\
\hline $\mathrm{C}$ & 1.43415800 & -3.46602000 & -0.20559500 \\
\hline C & 2.23897200 & -4.61494200 & -0.15767500 \\
\hline $\mathrm{H}$ & 3.29405800 & -4.52038400 & 0.07384900 \\
\hline C & 1.71658700 & -5.88989200 & -0.41230700 \\
\hline $\mathrm{C}$ & 2.53420300 & -7.06234100 & -0.37209200 \\
\hline $\mathrm{H}$ & 3.58925800 & -6.95002300 & -0.13397500 \\
\hline $\mathrm{C}$ & 2.00452800 & -8.29964600 & -0.62824200 \\
\hline $\mathrm{H}$ & 2.63733600 & -9.18234600 & -0.59527400 \\
\hline $\mathrm{C}$ & 0.61988200 & -8.44170500 & -0.94013400 \\
\hline $\mathrm{H}$ & 0.21768400 & -9.43115200 & -1.14056100 \\
\hline $\mathrm{C}$ & -0.19902600 & -7.34433900 & -0.98691000 \\
\hline $\mathrm{H}$ & -1.25521600 & -7.44972700 & -1.22215400 \\
\hline C & 0.31341700 & -6.03485400 & -0.72622400 \\
\hline $\mathrm{C}$ & -0.49623800 & -4.89426600 & -0.74779300 \\
\hline $\mathrm{H}$ & -1.56093600 & -4.96930300 & -0.94938000 \\
\hline $\mathrm{C}$ & 0.03067700 & -3.62347500 & -0.48125200 \\
\hline$\tau$ & -3.39418600 & -1.90799500 & 0.04225400 \\
\hline $\mathrm{C}$ & -3.95207100 & -2.28096400 & -1.17883000 \\
\hline $\mathrm{H}$ & -3.84000200 & -1.61238100 & -2.02736300 \\
\hline $\mathrm{C}$ & -4.62576100 & -3.50398900 & -1.32767900 \\
\hline $\mathrm{C}$ & -4.73140700 & -4.32870400 & -0.20290600 \\
\hline $\mathrm{H}$ & -5.24757400 & -5.27733700 & -0.29253000 \\
\hline $\mathrm{C}$ & -4.20410500 & -3.97024000 & 1.05238700 \\
\hline $\mathrm{C}$ & -3.54684100 & -2.74347700 & 1.15791900 \\
\hline $\mathrm{H}$ & -3.12287000 & -2.42257300 & 2.10229600 \\
\hline $\mathrm{C}$ & -5.21919600 & -3.88227700 & -2.69889700 \\
\hline $\mathrm{C}$ & -5.91080100 & -5.25871600 & -2.68444400 \\
\hline $\mathrm{H}$ & -6.74819400 & -5.28872700 & -1.97798800 \\
\hline $\mathrm{H}$ & -5.21370200 & -6.06316200 & -2.42312200 \\
\hline $\mathrm{H}$ & -6.31146400 & -5.48014200 & -3.68017600 \\
\hline C & -6.26832800 & -2.82305800 & -3.11347500 \\
\hline $\mathrm{H}$ & -7.08933600 & -2.78044900 & -2.38834300 \\
\hline $\mathrm{H}$ & -6.69395100 & -3.06945000 & -4.09415100 \\
\hline $\mathrm{H}$ & -5.83109100 & -1.82164400 & -3.18184700 \\
\hline $\mathrm{C}$ & -4.09085500 & -3.92415300 & -3.75679200 \\
\hline $\mathrm{H}$ & -4.49976100 & -4.18460600 & -4.74097800 \\
\hline $\mathrm{H}$ & -3.33438400 & -4.67250400 & -3.49403000 \\
\hline $\mathrm{H}$ & -3.58290000 & -2.95910900 & -3.85094700 \\
\hline $\mathrm{C}$ & -4.37095300 & -4.92775700 & 2.24843500 \\
\hline $\mathrm{C}$ & -5.87651800 & -5.15202900 & 2.52666000 \\
\hline $\mathrm{H}$ & -6.37351400 & -4.20694500 & 2.77444800 \\
\hline $\mathrm{H}$ & -6.01093600 & -5.83801900 & 3.37217200 \\
\hline $\mathrm{H}$ & -6.39203700 & -5.58394400 & 1.66240800 \\
\hline $\mathrm{C}$ & -3.70353400 & -6.28450300 & 1.91886800 \\
\hline $\mathrm{H}$ & -3.81038300 & -6.97749200 & 2.76264400 \\
\hline $\mathrm{H}$ & -2.63412200 & -6.15575100 & 1.71714500 \\
\hline $\mathrm{H}$ & -4.15552100 & -6.75857200 & 1.04107400 \\
\hline & -3.72416600 & -4.37913200 & 3.53452100 \\
\hline & -4.17392400 & -3.42911100 & 3.8448130 \\
\hline
\end{tabular}




\begin{tabular}{|c|c|c|c|}
\hline $\mathrm{H}$ & -2.64613600 & -4.22449800 & 3.41391400 \\
\hline $\mathrm{H}$ & -3.86636700 & -5.09428200 & 4.35275200 \\
\hline $\mathrm{C}$ & 3.40013300 & -1.99665400 & 0.26335600 \\
\hline $\mathrm{C}$ & 4.33754500 & -2.20815000 & -0.75903600 \\
\hline $\mathrm{H}$ & 3.97026700 & -2.40096600 & -1.76017200 \\
\hline C & 5.70805900 & -2.14646100 & -0.50290000 \\
\hline C & 6.11933900 & -1.88046500 & 0.81736100 \\
\hline $\mathrm{H}$ & 7.18160500 & -1.83196100 & 1.02631200 \\
\hline C & 5.21271000 & -1.69026000 & 1.86456600 \\
\hline $\mathrm{C}$ & 3.84334900 & -1.76283800 & 1.56365700 \\
\hline $\mathrm{H}$ & 3.10427900 & -1.61805500 & 2.34624300 \\
\hline $\mathrm{C}$ & 6.76810500 & -2.36594600 & -1.60039900 \\
\hline $\mathrm{C}$ & 6.13796900 & -2.64386400 & -2.97850400 \\
\hline $\mathrm{H}$ & 5.51546800 & -1.80853800 & -3.31812100 \\
\hline $\mathrm{H}$ & 5.52005500 & -3.54885400 & -2.96972500 \\
\hline $\mathrm{H}$ & 6.92870900 & -2.79135600 & -3.72293600 \\
\hline $\mathrm{C}$ & 7.65547300 & -3.57709700 & -1.22590100 \\
\hline $\mathrm{H}$ & 7.05463000 & -4.48984600 & -1.13949700 \\
\hline $\mathrm{H}$ & 8.17194700 & -3.42623200 & -0.27221400 \\
\hline $\mathrm{H}$ & 8.41853800 & -3.74492000 & -1.99602200 \\
\hline $\mathrm{C}$ & 7.65426800 & -1.10375300 & -1.72617400 \\
\hline $\mathrm{H}$ & 8.42139700 & -1.25031800 & -2.49662700 \\
\hline $\mathrm{H}$ & 8.16653900 & -0.86872400 & -0.78720500 \\
\hline $\mathrm{H}$ & 7.05282300 & -0.23196900 & -2.00942900 \\
\hline $\mathrm{C}$ & 5.65789200 & -1.40807600 & 3.31257800 \\
\hline $\mathrm{C}$ & 7.19041600 & -1.35346700 & 3.45956100 \\
\hline $\mathrm{H}$ & 7.66233400 & -2.30271000 & 3.18101100 \\
\hline $\mathrm{H}$ & 7.45313200 & -1.14875600 & 4.50362600 \\
\hline $\mathrm{H}$ & 7.63135100 & -0.55869600 & 2.84707300 \\
\hline $\mathrm{C}$ & 5.12677300 & -2.52536500 & 4.24200300 \\
\hline $\mathrm{H}$ & 4.03417700 & -2.59205700 & 4.21660700 \\
\hline $\mathrm{H}$ & 5.42528900 & -2.33300900 & 5.28001500 \\
\hline $\mathrm{H}$ & 5.52781300 & -3.50258100 & 3.94897300 \\
\hline $\mathrm{C}$ & 5.08365300 & -0.04578600 & 3.76952400 \\
\hline $\mathrm{H}$ & 5.44062100 & 0.76570500 & 3.12534600 \\
\hline $\mathrm{H}$ & 5.39343800 & 0.17312600 & 4.79895800 \\
\hline $\mathrm{H}$ & 3.98935400 & -0.03451000 & 3.74106500 \\
\hline $\mathrm{C}$ & 0.00863800 & 3.92550700 & -0.31877400 \\
\hline $\mathrm{C}$ & -0.05367500 & 4.85014400 & 0.72804400 \\
\hline $\mathrm{H}$ & 0.51330900 & 4.64779200 & 1.63186900 \\
\hline $\mathrm{C}$ & -0.84306600 & 6.00275900 & 0.63401000 \\
\hline $\mathrm{C}$ & -1.56449300 & 6.20846300 & -0.55226200 \\
\hline $\mathrm{H}$ & -2.18012300 & 7.09282900 & -0.64130700 \\
\hline $\mathrm{C}$ & -1.50782400 & 5.31291100 & -1.63038800 \\
\hline $\mathrm{C}$ & -0.70073200 & 4.17634600 & -1.49599500 \\
\hline $\mathrm{H}$ & -0.62824500 & 3.45845300 & -2.30783500 \\
\hline $\mathrm{C}$ & -2.29498100 & 5.53561100 & -2.93688900 \\
\hline $\mathrm{C}$ & -3.25900700 & 4.34619300 & -3.16239500 \\
\hline $\mathrm{H}$ & -2.72042700 & 3.39704500 & -3.25004600 \\
\hline $\mathrm{H}$ & -3.83442500 & 4.49034600 & -4.08534200 \\
\hline $\mathrm{H}$ & -3.96536800 & 4.25090900 & -2.33008300 \\
\hline $\mathrm{C}$ & -1.30843400 & 5.62786300 & -4.12519700 \\
\hline $\mathrm{H}$ & -0.62009300 & 6.47156600 & -3.99868800 \\
\hline $\mathrm{H}$ & -1.85503600 & 5.77336200 & -5.06522300 \\
\hline $\mathrm{H}$ & -0.70653600 & 4.71901800 & -4.22735200 \\
\hline $\mathrm{C}$ & -3.13150200 & 6.82909300 & -2.91052600 \\
\hline $\mathrm{H}$ & -3.87817500 & 6.81654000 & -2.10839100 \\
\hline $\mathrm{H}$ & -3.66923700 & 6.93867700 & -3.8591730 \\
\hline $\mathrm{H}$ & -2.50528700 & 7.71941600 & -2.7820360 \\
\hline
\end{tabular}




$\begin{array}{lrll}\mathrm{C} & -0.88211800 & 6.99670200 & 1.81243400 \\ \mathrm{C} & -1.81060700 & 8.19660600 & 1.54443000 \\ \mathrm{H} & -1.48611200 & 8.77990200 & 0.67521900 \\ \mathrm{H} & -1.80557800 & 8.86693300 & 2.41149100 \\ \mathrm{H} & -2.84694800 & 7.88153900 & 1.37689900 \\ \mathrm{C} & 0.54336100 & 7.54219100 & 2.06856200 \\ \mathrm{H} & 1.24900200 & 6.74041100 & 2.30951200 \\ \mathrm{H} & 0.53873700 & 8.24712400 & 2.90918700 \\ \mathrm{H} & 0.92445600 & 8.06950900 & 1.18619100 \\ \mathrm{C} & -1.38728400 & 6.27650200 & 3.08503500 \\ \mathrm{H} & -2.40356200 & 5.89154900 & 2.94072300 \\ \mathrm{H} & -1.40564800 & 6.97015100 & 3.93484100 \\ \mathrm{H} & -0.74827800 & 5.43081600 & 3.35803600\end{array}$

\section{TAA-OMePh}

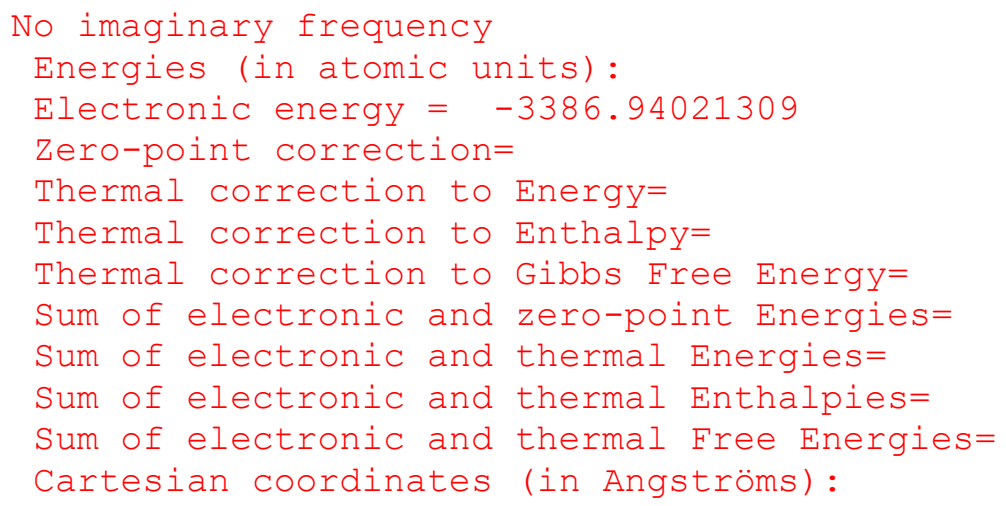

$$
\begin{array}{r}
3.50851700 \\
3.40706800 \\
2.10897900 \\
4.24773700 \\
3.26833200 \\
-7.63307300 \\
4.28505900 \\
-6.98945100 \\
-5.64966900 \\
0.32233000 \\
-2.47541000 \\
2.16702600 \\
2.64677800 \\
0.13674400 \\
-1.53151100 \\
-0.74198000 \\
1.86445400 \\
3.81760500 \\
3.39054700 \\
2.63950100 \\
-1.18180300 \\
1.34580700 \\
-2.28719900 \\
-0.31650300 \\
-3.68314700 \\
3.00228500 \\
-1.61521600 \\
-2.87926900 \\
-0.49494200
\end{array}
$$

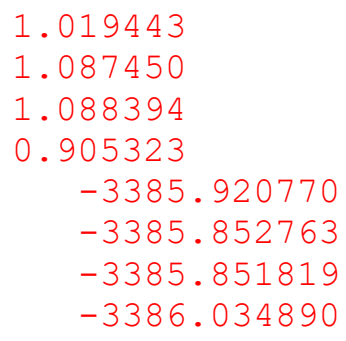

-0.28555800
3.25969700
-2.44716200
-1.26009900
2.05194000
-1.14011800
1.31002700
1.25132400
-3.08846300
-0.03540700
0.60003700
-0.53443900
0.01217900
0.01137000
-0.34170700
-0.14597900
-1.29859700
0.98656900
1.99509100
-0.18940900
-0.00667800
-0.01800600
-0.21023800
0.19677200
-0.42215100
0.33812200
0.56476400
-0.52138200
-0.16548000 
0.53280000

$-0.14363800$

0.76129100

0.91676400

0.31892100

3. 83014400

$-1.29957500$

1.17593100

2. 46588600

$-2.08667100$

$-3.12132700$

$-4.13744100$

3. 44192400

3.44516900

$-5.97498100$

1.51310600

1. 36645700

$-4.21698200$

$-1.89560300$

$-1.11422000$

3. 74601900

2. 99511600

2. 66055200

6.12388400

$-4.66059300$

$-4.37316200$

$-2.66932200$

$-1.30637400$

$-0.29119800$

$-4.03940700$

$-3.30711000$

$-3.93172100$

$-4.94430700$

$-3.67403100$

$-4.48309900$

5.80239100

1.35324900

0.27919000

1. 70411700

1.51803900

$-2.34395600$

$-2.15927800$

$-3.16502500$

5.09232800

5. 34712300

$-6.33167800$

$-6.69649900$

$-5.94249400$

$-7.63539200$

$-6.34634600$

$-3.93930600$

$-4.70877700$

3.43768000

3.14390900

3. 37261100

3. 87159400

2. 13791100

4. 46335400

4. 18800100
5.34974200

$-1.41905100$

$-3.82639300$

$-4.48662500$

$-4.17842000$

4.73459600

$-0.56172700$

$-0.78966400$

$-5.22951300$

3.14513800

4.07052700

3.71646100

3. 42854000

3. 08441000

0.98868100

$-4.21052500$

$-3.69770300$

$-4.13149300$

$-4.65666100$

$-5.39094800$

0.25931000

2. 98366400

2. 29794300

$-0.23009100$

1. 40201100

1.83296700

$-2.33932900$

7.35238100

7.71736600

0.67620700

0.54150000

6.39762900

6.02589300

7.74308200

8.45229000

$-1.58842100$

$-5.87269100$

$-6.03406000$

$-6.54230600$

$-4.83152000$

8.22617400

9.29692600

$-5.09733100$

0.65545900

1.67281000

0.41106000

1.66646800

1.08382300

1.65565800

2.70219500

$-2.77423400$

$-2.02212500$

$-1.10574800$

$-5.03493700$

$-3.96241100$

$-5.52622400$

$-5.16701500$

$-1.99278100$

$-3.01492000$
$-0.04789600$

0.03675600

0.04572900

$-1.17671400$

$-2.02545800$

$-0.35110900$

0.21740800

$-0.21035400$

1.03758700

$-0.28762100$

$-0.49441900$

$-0.62897500$

$-0.67153500$

$-1.69829400$

0.34211600

1.15990400

2.10256400

1.37184100

0.75379200

0.59228500

$-0.26224400$

1. 67222400

2. 44085500

$-0.58098900$

0.56880100

1.52006200

0.78106600

$-0.36573500$

$-0.22998300$

$-1.65481000$

$-2.44385000$

$-0.72083600$

$-0.85843000$

$-0.73790200$

$-0.88983400$

$-0.95530700$

$-3.60093900$

$-3.44040900$

$-4.38852900$

$-3.90845500$

$-0.55706600$

$-0.57347700$

1.14940100

$-0.24178000$

0.03347500

$-0.89535200$

2. 51494700

3. 06062500

3. 07173900

2. 41492000

1.18205100

1. 32911000

$-0.59734300$

3. 31702100

3. 26101700

3. 96579800

3. 73685000

$-0.94832700$

$-1.19129500$ 


$\begin{array}{lrrr}\text { C } & -5.35515200 & 0.26274900 & -1.88735700 \\ \mathrm{C} & 6.86937700 & -2.47484700 & -1.30242000 \\ \mathrm{H} & 6.62372200 & -3.49603500 & -1.58346000 \\ \mathrm{C} & -3.45567900 & -6.48416900 & 1.34291300 \\ \mathrm{H} & -2.66188500 & -7.20799500 & 1.17500800 \\ \mathrm{C} & 8.17150200 & -2.04918400 & -1.28095700 \\ \mathrm{H} & 8.97310500 & -2.73283600 & -1.54736300 \\ \mathrm{C} & -5.74192000 & -5.94041200 & 1.94978700 \\ \mathrm{H} & -6.72568400 & -6.28497100 & 2.25712400 \\ \mathrm{C} & 4.83445200 & -6.59627000 & -0.67078700 \\ \mathrm{H} & 4.84657500 & -6.14061500 & -1.66971600 \\ \mathrm{H} & 5.40812200 & -7.52643300 & -0.69351500 \\ \mathrm{H} & 5.28736300 & -5.90935200 & 0.05547600 \\ \mathrm{C} & 7.49643200 & 0.17100300 & -0.56959000 \\ \mathrm{H} & 7.73515700 & 1.19315100 & -0.28576300 \\ \mathrm{C} & -5.50559700 & -4.60230000 & 1.77555600 \\ \mathrm{H} & -6.29502300 & -3.87327400 & 1.94187700 \\ \mathrm{C} & -7.97878700 & -1.25315300 & -0.62940500 \\ \mathrm{H} & -7.33601900 & -2.03021600 & -1.06092000 \\ \mathrm{H} & -9.01573400 & -1.43127100 & -0.92480000 \\ \mathrm{H} & -7.90454000 & -1.27412100 & 0.46429000 \\ \mathrm{C} & -4.70389800 & -6.89423800 & 1.73091800 \\ \mathrm{H} & -4.91155100 & -7.95105000 & 1.87445200 \\ \mathrm{C} & 4.28934300 & 5.28548600 & -2.62687400 \\ \mathrm{H} & 4.98318800 & 4.45130800 & -2.79514200 \\ \mathrm{H} & 4.64613800 & 6.16461900 & -3.16688700 \\ \mathrm{H} & 3.29538500 & 5.00712000 & -3.00150400 \\ \mathrm{C} & 2.99145700 & 3.96078700 & 4.32511900 \\ \mathrm{H} & 1.94800300 & 3.64013300 & 4.20588800 \\ \mathrm{H} & 3.08319500 & 4.56334900 & 5.23083400 \\ \mathrm{H} & 3.63231800 & 3.07368700 & 4.41433500 \\ \mathrm{C} & 8.48983000 & -0.70930000 & -0.90932000 \\ \mathrm{H} & 9.52878200 & -0.39140700 & -0.89754800 \\ \mathrm{C} & 3.28148100 & 7.42965600 & 1.36567000 \\ \mathrm{H} & 2.79770700 & 7.55955700 & 0.38834500 \\ \mathrm{H} & 3.79342100 & 8.35603700 & 1.63855600 \\ \mathrm{H} & 2.52481700 & 7.19637600 & 2.12511500 \\ \mathrm{C} & -6.53300400 & 0.39339300 & -3.94485700 \\ \mathrm{H} & -7.51068500 & 0.54030300 & -3.47711400 \\ \mathrm{H} & -6.64135700 & -0.20966300 & -4.84958800 \\ \mathrm{H} & -6.09944800 & 1.36719600 & -4.20978900 \\ & & & \\ & & & \end{array}$

\section{TAA-Tips}

No imaginary frequency

Energies (in atomic units):

Electronic energy $=-3825.22574738$

Zero-point correction=

Thermal correction to Energy=

Thermal correction to Enthalpy=

Thermal correction to Gibbs Free Energy=

Sum of electronic and zero-point Energies=

Sum of electronic and thermal Energies=

Sum of electronic and thermal Enthalpies=

Sum of electronic and thermal Free Energies=

Cartesian coordinates (in Angströms):

1.339983

1.422327

1. 423271

1.213229

$-3823.885765$

$-3823.803421$

$-3823.802477$

$-3824.012519$ 


$\begin{array}{lrrr}\mathrm{H} & -7.14415200 & -3.99154600 & -0.11665100 \\ \mathrm{C} & -6.60400900 & -6.62955600 & 0.79328200 \\ \mathrm{H} & -7.32342900 & -6.14144900 & 1.46173200 \\ \mathrm{H} & -6.05788600 & -7.37475900 & 1.38412800 \\ \mathrm{H} & -7.18553500 & -7.17370700 & 0.03676800 \\ \mathrm{C} & -6.26513500 & -2.87135200 & 2.52890800 \\ \mathrm{H} & -7.17650600 & -3.33098000 & 2.12699800 \\ \mathrm{H} & -5.89294800 & -2.15736800 & 1.78597700 \\ \mathrm{H} & -6.56019400 & -2.29891800 & 3.41886900 \\ \mathrm{C} & -1.59974900 & 7.44776100 & 1.17640900 \\ \mathrm{H} & -2.35377900 & 8.23666500 & 1.32588500 \\ \mathrm{C} & -4.02310200 & 5.49448900 & 1.20537400 \\ \mathrm{H} & -3.56746000 & 5.03880400 & 2.09846300 \\ \mathrm{C} & -2.82995600 & 6.71025500 & -1.59150200 \\ \mathrm{H} & -1.84158400 & 7.07246400 & -1.91424200 \\ \mathrm{C} & -4.85987600 & 4.39871100 & 0.52110700 \\ \mathrm{H} & -5.62366000 & 4.00961300 & 1.20820100 \\ \mathrm{H} & -4.24488400 & 3.55391500 & 0.19631500 \\ \mathrm{H} & -5.38917000 & 4.78573700 & -0.35827600 \\ \mathrm{C} & -3.79515400 & 7.91147000 & -1.63778500 \\ \mathrm{H} & -3.83855400 & 8.33562500 & -2.65015600 \\ \mathrm{H} & -3.49561600 & 8.71818100 & -0.95813300 \\ \mathrm{H} & -4.81642500 & 7.61562500 & -1.36928000 \\ \mathrm{C} & -3.25286900 & 5.62740100 & -2.59991200 \\ \mathrm{H} & -4.24903900 & 5.23096700 & -2.36977000 \\ \mathrm{H} & -2.54952400 & 4.78796500 & -2.60819100 \\ \mathrm{H} & -3.29544100 & 6.04075100 & -3.61710600 \\ \mathrm{C} & -4.92555800 & 6.64613900 & 1.69209100 \\ \mathrm{H} & -5.42204500 & 7.15514600 & 0.85739300 \\ \mathrm{H} & -4.37201800 & 7.40316400 & 2.25900100 \\ \mathrm{H} & -5.71674200 & 6.26012700 & 2.34910800 \\ \mathrm{C} & -0.42314800 & 8.08521500 & 0.41379200 \\ \mathrm{H} & 0.06620000 & 8.85479300 & 1.02686100 \\ \mathrm{H} & -0.74336400 & 8.56607900 & -0.51709900 \\ \mathrm{H} & 0.34130500 & 7.34335900 & 0.15086200 \\ \mathrm{C} & -1.15229600 & 6.96762500 & 2.57084000 \\ \mathrm{H} & -0.41971200 & 6.15498400 & 2.49866500 \\ \mathrm{H} & -1.99208300 & 6.59830500 & 3.17051500 \\ \mathrm{H} & -0.68256100 & 7.78570500 & 3.13390000 \\ \mathrm{C} & -1.36969200 & 4.61167300 & 0.05094800 \\ & & & \\ & & & \end{array}$

\section{TAA-CF 3 Ph}

No imaginary frequency

Energies (in atomic units):

Electronic energy $=-4378.50118483$

Zero-point correction=

Thermal correction to Energy=

Thermal correction to Enthalpy=

Thermal correction to Gibbs Free Energy=

Sum of electronic and zero-point Energies=

Sum of electronic and thermal Energies=

Sum of electronic and thermal Enthalpies=

Sum of electronic and thermal Free Energies=

Cartesian coordinates (in Angströms):

$\begin{array}{llll}\text { C } & -0.18416500 & -3.68977600 & -0.33558400 \\ \text { C } & -0.44525800 & -1.39199600 & -0.15210900\end{array}$




\begin{tabular}{|c|c|c|c|}
\hline C & 0.98716600 & -1.18324500 & -0.04314600 \\
\hline $\mathrm{C}$ & 1.80515800 & -2.30440800 & 0.07316300 \\
\hline C & 1.23062700 & -3.61206000 & -0.07505400 \\
\hline $\mathrm{C}$ & -1.36881600 & -0.24912500 & 0.05025100 \\
\hline $\mathrm{C}$ & 1.51763800 & 0.19453400 & -0.13916500 \\
\hline $\mathrm{C}$ & 0.62289100 & 1.32327200 & 0.00146000 \\
\hline $\mathrm{C}$ & -0.80363000 & 1.06570700 & 0.29750100 \\
\hline $\mathrm{C}$ & 1.14121200 & 2.60048100 & -0.20308400 \\
\hline $\mathrm{C}$ & 2.54175000 & 2.75378000 & -0.48696100 \\
\hline $\mathrm{C}$ & 3.33568000 & 1.55677600 & -0.59608100 \\
\hline $\mathrm{C}$ & -2.75371800 & -0.38476900 & 0.14402400 \\
\hline $\mathrm{C}$ & -3.54465300 & 0.73515000 & 0.57985900 \\
\hline $\mathrm{C}$ & -2.84936000 & 1.94368500 & 0.94013900 \\
\hline $\mathrm{C}$ & -4.94164900 & 0.70270000 & 0.71210800 \\
\hline $\mathrm{C}$ & -5.65718500 & 1.79648200 & 1.21755500 \\
\hline $\mathrm{C}$ & -4.94582700 & 2.99015000 & 1.61371800 \\
\hline $\mathrm{C}$ & -3.55630500 & 3.03391800 & 1.46100300 \\
\hline $\mathrm{H}$ & -5.49129500 & -0.18784300 & 0.42752600 \\
\hline $\mathrm{H}$ & -3.00051600 & 3.92392700 & 1.73820300 \\
\hline $\mathrm{C}$ & 1.96821500 & -4.80318000 & -0.00285200 \\
\hline $\mathrm{C}$ & 1.36925400 & -6.05125900 & -0.21766800 \\
\hline $\mathrm{C}$ & -0.78646000 & -4.93486300 & -0.55452700 \\
\hline $\mathrm{C}$ & -0.04460900 & -6.12009500 & -0.50991700 \\
\hline $\mathrm{H}$ & -1.85473400 & -4.95772300 & -0.74813600 \\
\hline $\mathrm{H}$ & 3.03104600 & -4.76761000 & 0.21166300 \\
\hline $\mathrm{C}$ & 3.16746700 & 3.99444800 & -0.68375400 \\
\hline $\mathrm{C}$ & 4.53393400 & 4.08914200 & -0.97837400 \\
\hline $\mathrm{C}$ & 4.69908600 & 1.64501200 & -0.90499200 \\
\hline $\mathrm{C}$ & 5.32068500 & 2.88263300 & -1.09666200 \\
\hline $\mathrm{H}$ & 2.58924100 & 4.90889600 & -0.60481600 \\
\hline $\mathrm{H}$ & 5.26658500 & 0.72493400 & -1.00130700 \\
\hline $\mathrm{N}$ & -0.97512000 & -2.58177400 & -0.32217200 \\
\hline $\mathrm{N}$ & 2.79169100 & 0.32012400 & -0.43514200 \\
\hline $\mathrm{N}$ & -1.50637300 & 2.07369300 & 0.75948500 \\
\hline $\mathrm{C}$ & -5.68836500 & 4.09370600 & 2.13735300 \\
\hline $\mathrm{C}$ & -7.05095500 & 4.02364300 & 2.26053400 \\
\hline $\mathrm{H}$ & -7.60638400 & 4.86775900 & 2.65971200 \\
\hline $\mathrm{C}$ & -7.75496400 & 2.84687300 & 1.86739100 \\
\hline $\mathrm{H}$ & -8.83568400 & 2.81249800 & 1.97290600 \\
\hline $\mathrm{C}$ & -7.07925700 & 1.76766200 & 1.36161900 \\
\hline $\mathrm{H}$ & -7.61405500 & 0.86955600 & 1.06275800 \\
\hline $\mathrm{H}$ & -5.14576800 & 4.98785500 & 2.43356400 \\
\hline $\mathrm{C}$ & -0.63850100 & -7.40182400 & -0.72958300 \\
\hline $\mathrm{H}$ & -1.70209100 & -7.45043700 & -0.94823400 \\
\hline $\mathrm{C}$ & 0.11530500 & -8.54385900 & -0.66491800 \\
\hline $\mathrm{H}$ & -0.34733200 & -9.51223600 & -0.83386300 \\
\hline $\mathrm{C}$ & 1.51039000 & -8.47662300 & -0.37562000 \\
\hline $\mathrm{H}$ & 2.08980300 & -9.39437500 & -0.32850400 \\
\hline $\mathrm{C}$ & 2.11755100 & -7.26795500 & -0.15861300 \\
\hline $\mathrm{H}$ & 3.18076600 & -7.21369200 & 0.06178700 \\
\hline $\mathrm{C}$ & 6.71150000 & 2.99404100 & -1.40902000 \\
\hline $\mathrm{C}$ & 7.29098100 & 4.22195100 & -1.5896650 \\
\hline $\mathrm{H}$ & 8.34868300 & 4.29620600 & -1.8265440 \\
\hline $\mathrm{C}$ & 6.51628200 & 5.41401900 & -1.46983600 \\
\hline $\mathrm{H}$ & 6.99583100 & 6.37774900 & -1.61667100 \\
\hline $\mathrm{C}$ & 5.18021800 & 5.34937600 & -1.17393600 \\
\hline $\mathrm{H}$ & 4.58815900 & 6.25676800 & -1.0841400 \\
\hline $\mathrm{H}$ & 7.29528300 & 2.08159800 & -1.5001160 \\
\hline $\mathrm{C}$ & 0.31209700 & 3.84899500 & -0.2375220 \\
\hline
\end{tabular}




\begin{tabular}{|c|c|c|c|}
\hline C & -0.22496300 & 4.27788200 & -1.45378700 \\
\hline $\mathrm{C}$ & 0.13387400 & 4.64500800 & 0.90016000 \\
\hline $\mathrm{C}$ & -0.95808000 & 5.46646600 & -1.52652800 \\
\hline $\mathrm{H}$ & -0.08456800 & 3.67803100 & -2.34711500 \\
\hline C & -0.60538400 & 5.82322000 & 0.82406500 \\
\hline $\mathrm{H}$ & 0.54627400 & 4.32515600 & 1.85056600 \\
\hline & -1.15739400 & 6.24318300 & -0.38922600 \\
\hline $\mathrm{H}$ & -1.73186800 & 7.16028500 & -0.44341400 \\
\hline C & 3.26054900 & -2.23098800 & 0.42001400 \\
\hline $\mathrm{C}$ & 4.25973300 & -2.40263500 & -0.54554000 \\
\hline $\mathrm{C}$ & 3.63310700 & -2.06028300 & 1.75577000 \\
\hline $\mathrm{C}$ & 5.60359700 & -2.35455600 & -0.18133000 \\
\hline $\mathrm{H}$ & 3.98552300 & -2.53687700 & -1.58604000 \\
\hline$C$ & 4.98297900 & -2.03065500 & 2.11802000 \\
\hline $\mathrm{H}$ & 2.86969300 & -1.93597200 & 2.51674200 \\
\hline C & 5.97603100 & -2.16945800 & 1.15271600 \\
\hline $\mathrm{H}$ & 7.02258300 & -2.13459600 & 1.43123600 \\
\hline $\mathrm{C}$ & -3.50416900 & -1.64059600 & -0.17652300 \\
\hline $\mathrm{C}$ & -3.84989500 & -1.93275400 & -1.49988200 \\
\hline $\mathrm{C}$ & -3.96232600 & -2.47876800 & 0.84563700 \\
\hline $\mathrm{C}$ & -4.60081000 & -3.06999000 & -1.79808100 \\
\hline $\mathrm{H}$ & -3.51045200 & -1.28538800 & -2.30128600 \\
\hline $\mathrm{C}$ & -4.70754000 & -3.61838100 & 0.54178100 \\
\hline $\mathrm{H}$ & -3.71252000 & -2.25762400 & 1.87770700 \\
\hline $\mathrm{C}$ & -5.02779400 & -3.92477300 & -0.78135200 \\
\hline $\mathrm{H}$ & -5.59879700 & -4.81543000 & -1.01630700 \\
\hline $\mathrm{C}$ & -1.47866100 & 5.93343600 & -2.86074100 \\
\hline $\mathrm{C}$ & -0.90476900 & 6.59783400 & 2.07828400 \\
\hline $\mathrm{C}$ & 6.66619800 & -2.39465900 & -1.24533000 \\
\hline $\mathrm{C}$ & 5.35714300 & -1.90678700 & 3.57204000 \\
\hline $\mathrm{C}$ & -5.00337200 & -3.34856800 & -3.22301200 \\
\hline $\mathrm{C}$ & -5.22465700 & -4.49475600 & 1.65271600 \\
\hline $\mathrm{F}$ & -4.09325800 & -2.88098300 & -4.10368800 \\
\hline $\mathrm{F}$ & -5.15085900 & -4.67225200 & -3.45106000 \\
\hline $\mathrm{F}$ & -6.18433900 & -2.76214500 & -3.52708100 \\
\hline $\mathrm{F}$ & 7.81982600 & -2.92766200 & -0.79126000 \\
\hline F & 6.28062900 & -3.10656600 & -2.32386600 \\
\hline $\mathrm{F}$ & 6.96325400 & -1.14237000 & -1.68711100 \\
\hline $\mathrm{F}$ & 5.34826800 & -3.11117700 & 4.18897800 \\
\hline $\mathrm{F}$ & 6.59402800 & -1.38961900 & 3.73131000 \\
\hline $\mathrm{F}$ & 4.49260300 & -1.11579200 & 4.24392500 \\
\hline F & -5.32997700 & -5.78457300 & 1.26340800 \\
\hline F & -4.42254600 & -4.45945900 & 2.73779800 \\
\hline F & -6.45551600 & -4.10450300 & 2.05846100 \\
\hline $\mathrm{F}$ & -2.53113800 & 6.76824100 & -2.72719300 \\
\hline F & -0.52834500 & 6.60077600 & -3.55588400 \\
\hline $\mathrm{F}$ & -1.87282200 & 4.89702600 & -3.63226700 \\
\hline F & -2.06037100 & 6.16869500 & 2.65460100 \\
\hline $\mathrm{F}$ & -1.06111500 & 7.91617500 & 1.83557000 \\
\hline $\mathrm{F}$ & 0.06572200 & 6.46231600 & 3.00463600 \\
\hline
\end{tabular}




\section{F. NMR spectra of final compounds}

\section{TAN-Ph}
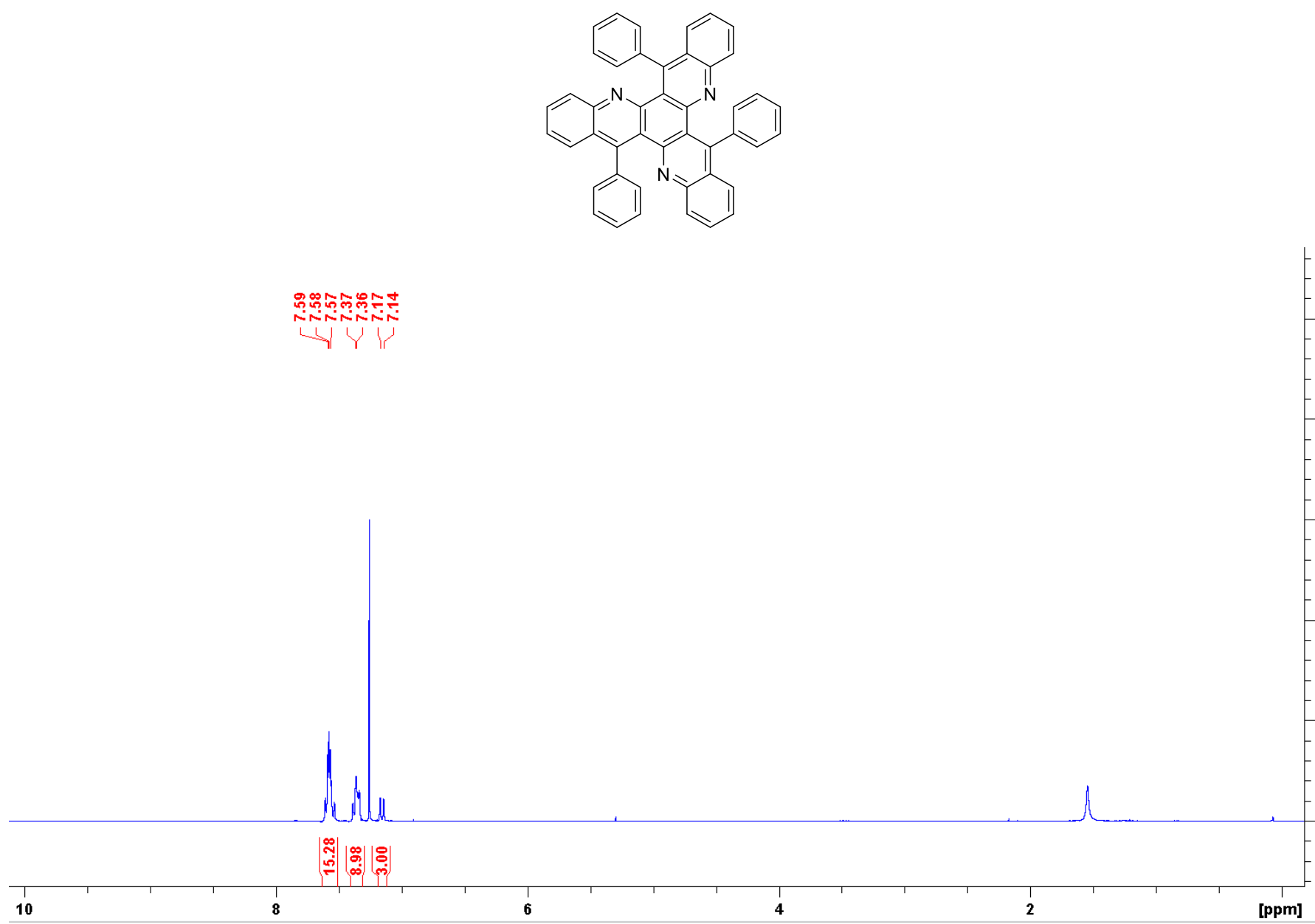

Figure S-F.1: ${ }^{1} \mathrm{H}$ NMR Spectrum $\left(300 \mathrm{MHz}, \mathrm{CDCl}_{3}\right)$.

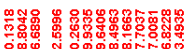

(1)

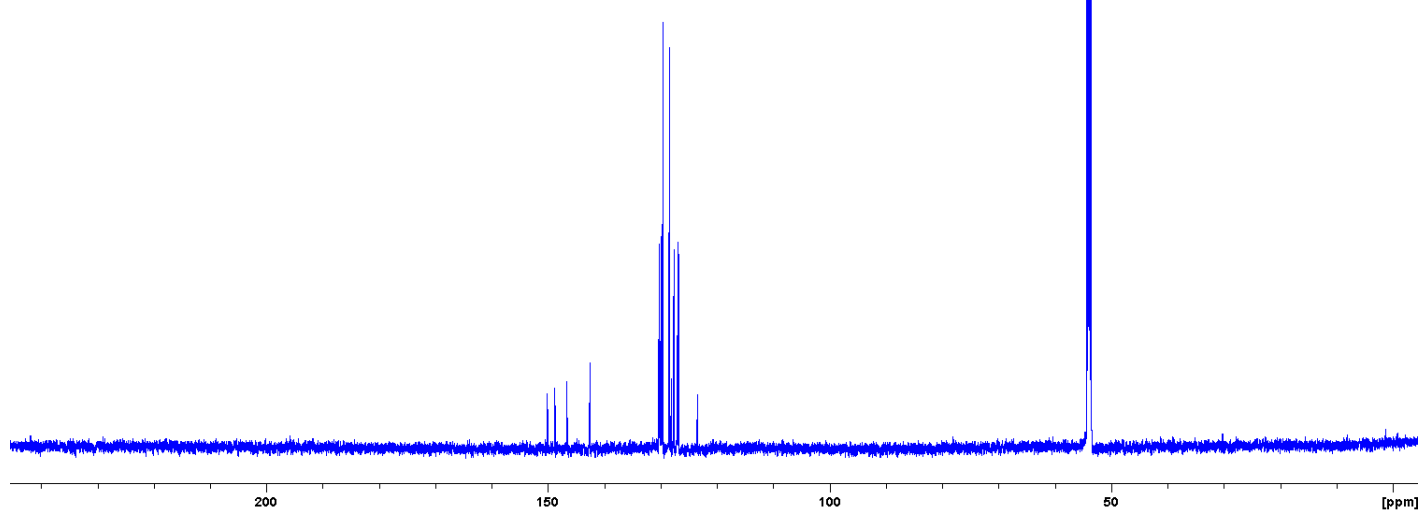

Figure S-F.2: ${ }^{13} \mathrm{C}$ NMR Spectrum (151 MHz, $\mathrm{CD}_{2} \mathrm{Cl}_{2}$ ). 


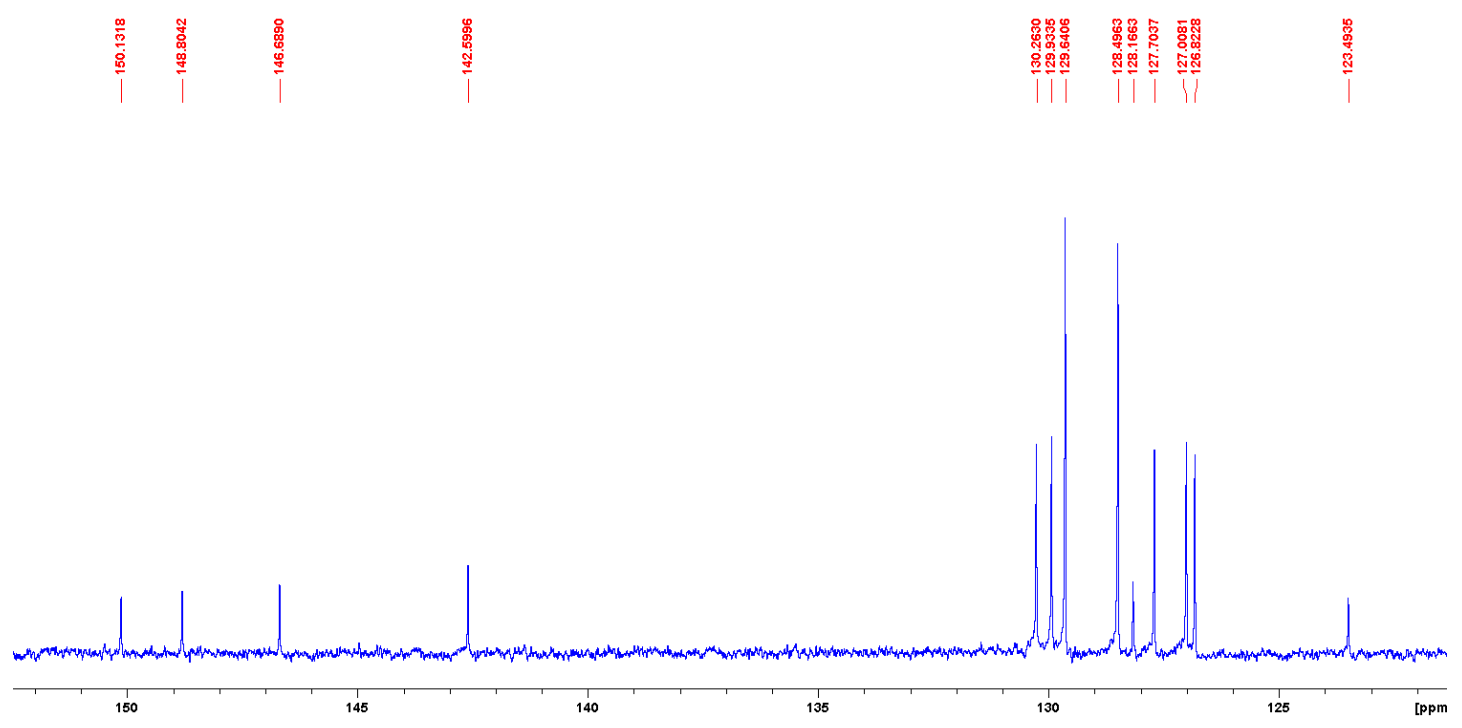

Figure S-F.3: ${ }^{13} \mathrm{C}$ NMR Spectrum, extension, $\left(151 \mathrm{MHz}, \mathrm{CD}_{2} \mathrm{Cl}_{2}\right)$. 


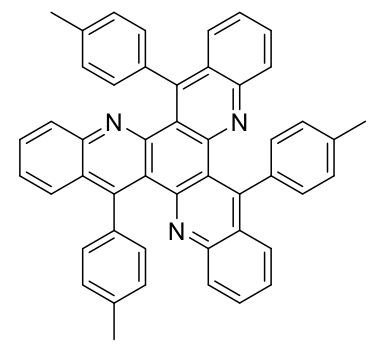

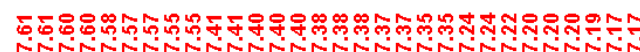

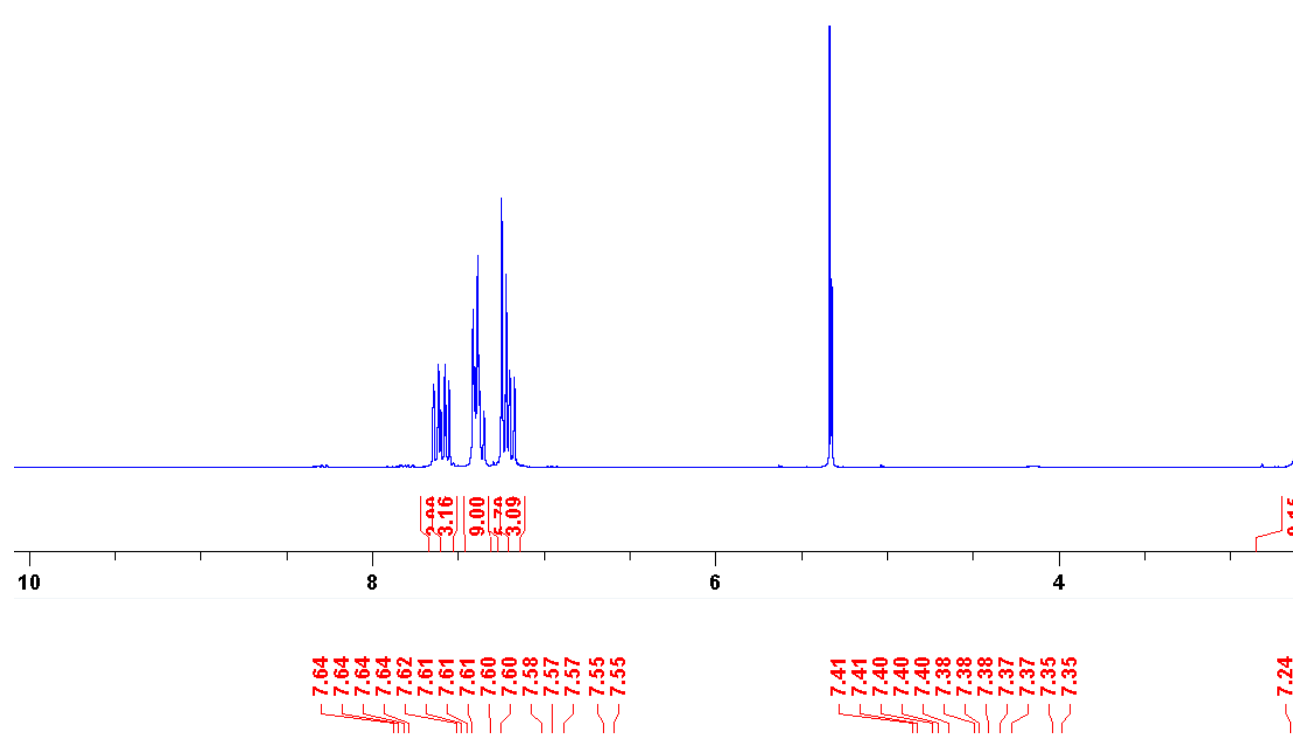

织:

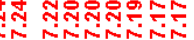

1) परोा पा

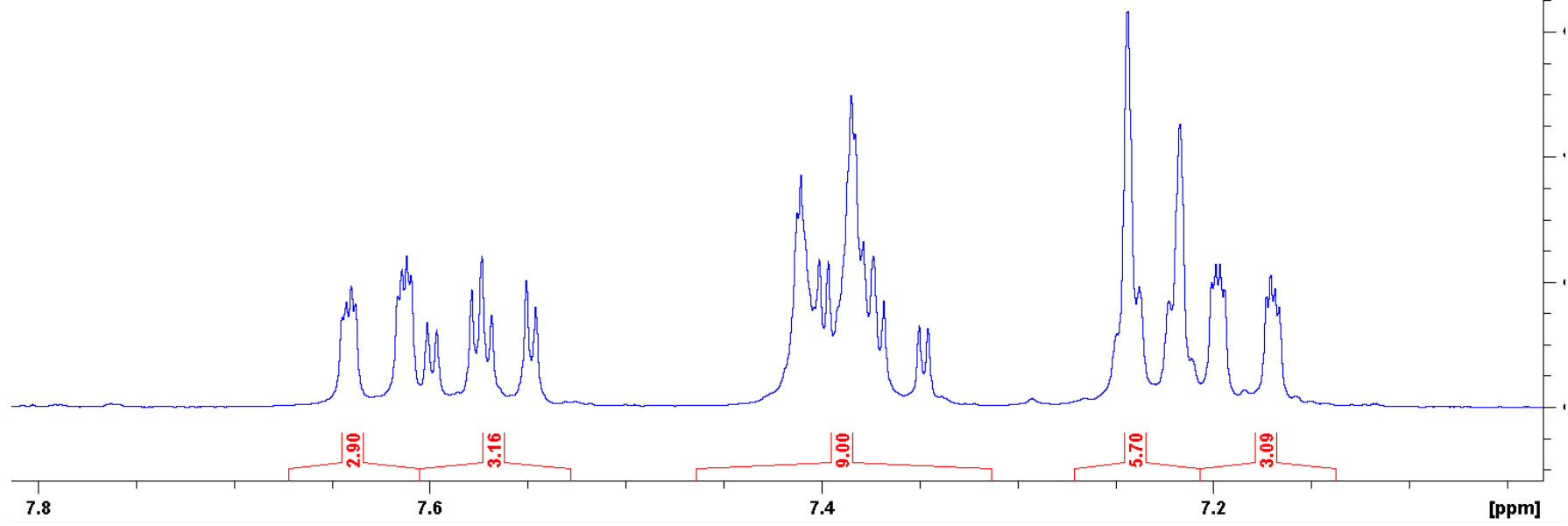

Figure S-F.4: ${ }^{1} \mathrm{H}$ NMR Spectrum $\left(300 \mathrm{MHz}, \mathrm{CD}_{2} \mathrm{Cl}_{2}\right)$. 


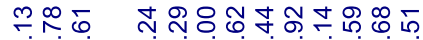

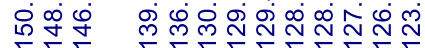

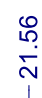<smiles>Cc1ccc(-c2c(-c3ccc(C)cc3)c3nc4ccccc4c(-c4ccc(C)cc4)c3c3c(-c4ccc(C)cc4)c4ccccc4nc23)cc1</smiles>

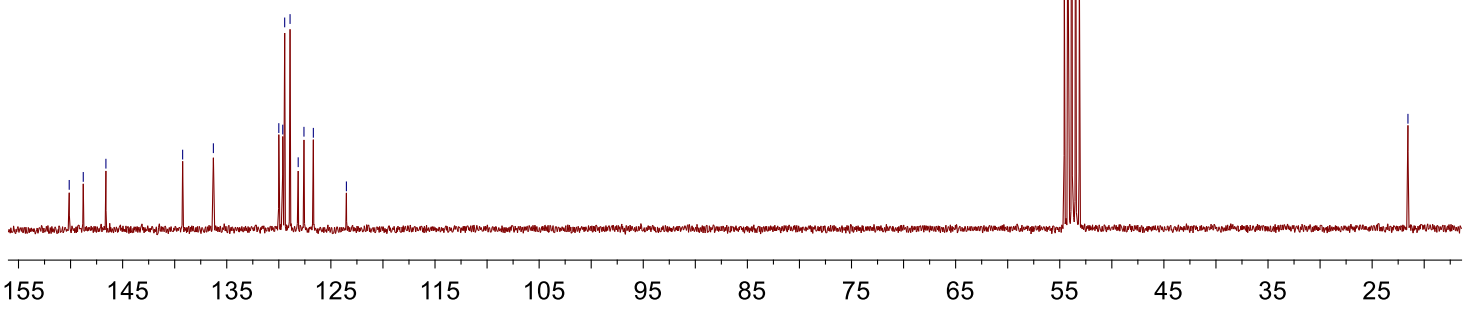

Figure S-F.5: ${ }^{13} \mathrm{C}$ NMR Spectrum $\left(75 \mathrm{MHz}, \mathrm{CD}_{2} \mathrm{Cl}_{2}\right)$. 


\section{3. $\boldsymbol{T A A}-\boldsymbol{P h}$}
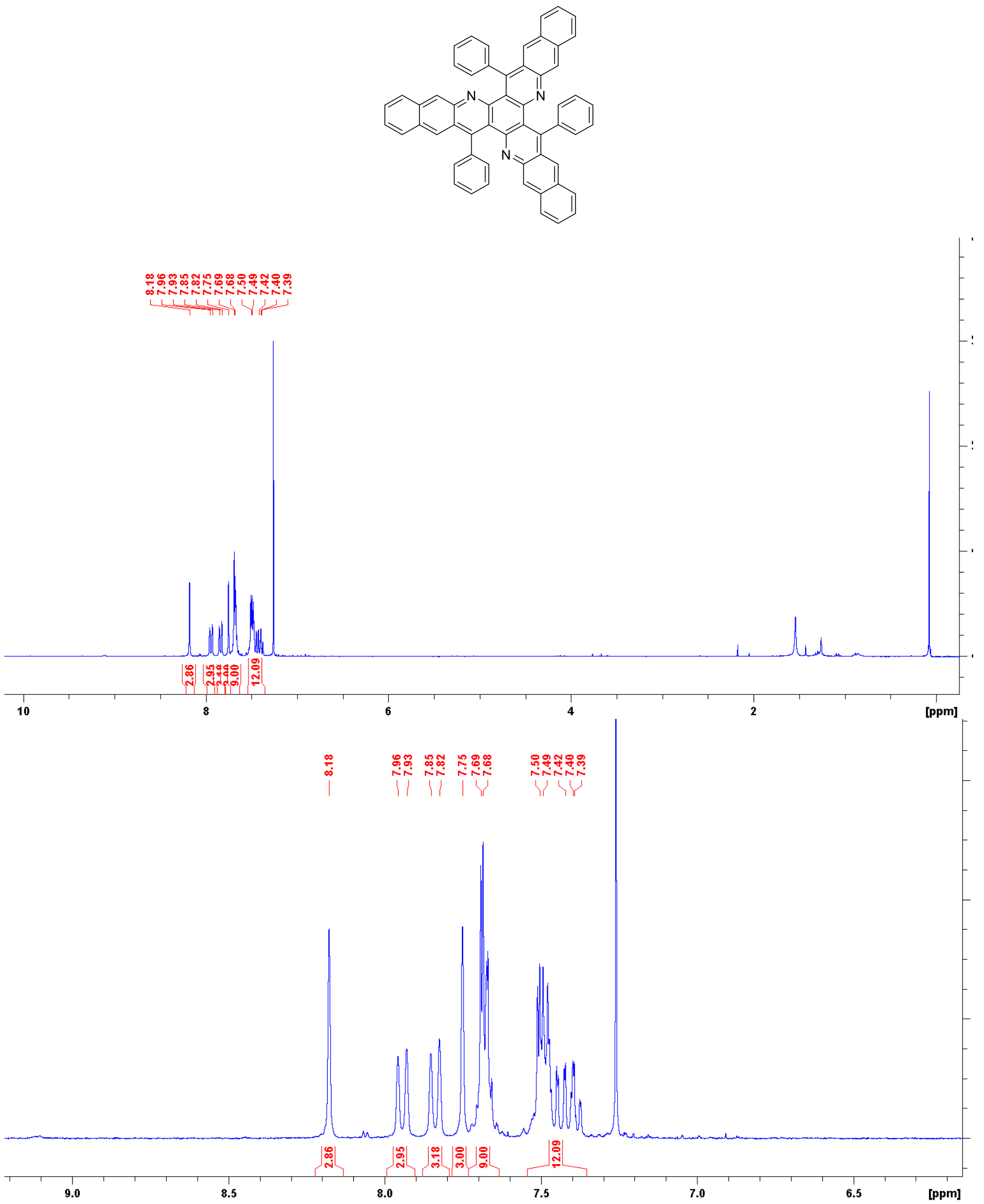

Figure S-F.6: ${ }^{1} \mathrm{H}$ NMR Spectrum ( $\left.300 \mathrm{MHz}, \mathrm{CDCl}_{3}\right)$. 


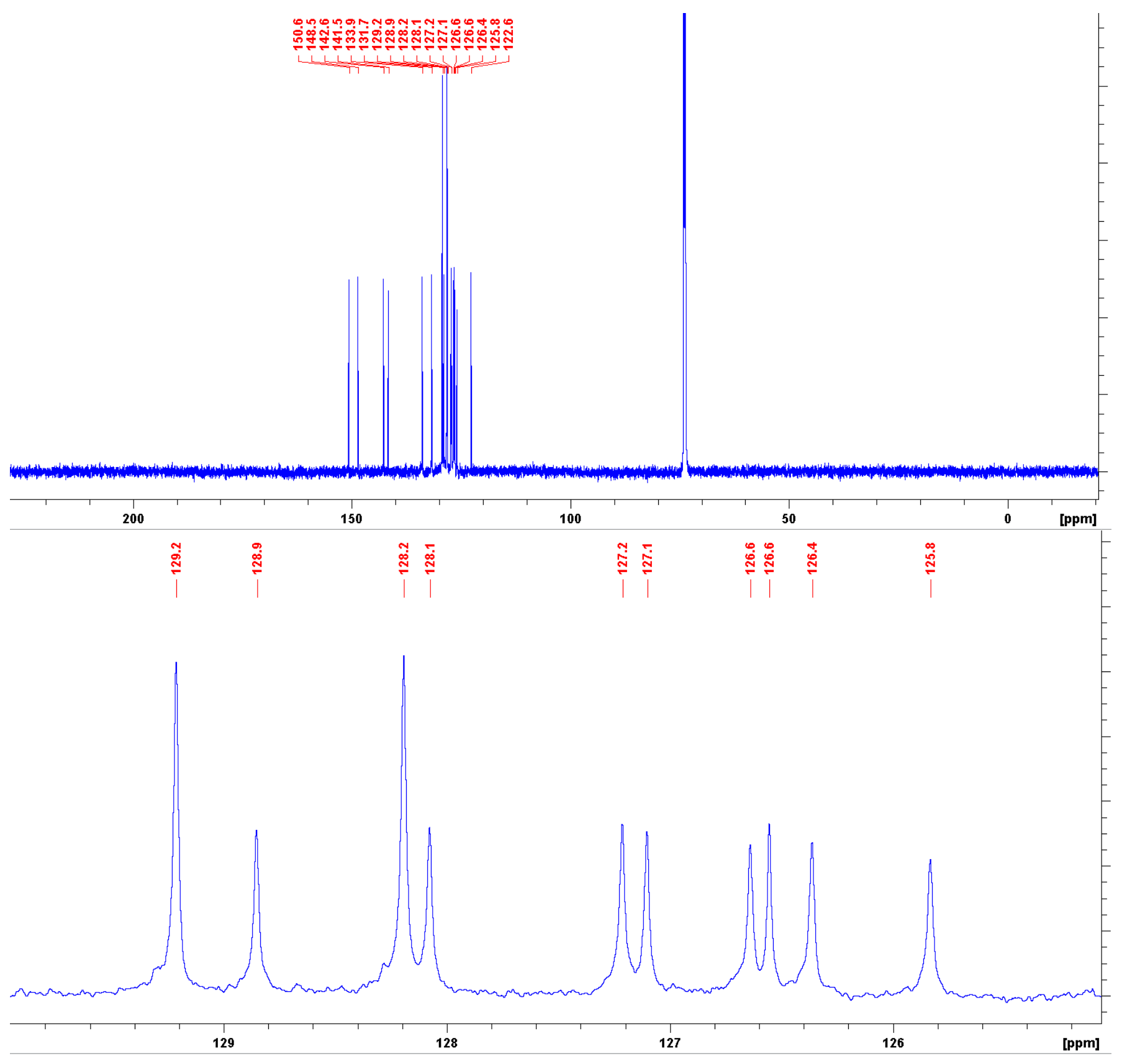

Figure S-F.7: ${ }^{13} \mathrm{C}$ NMR full Spectrum and expanded $\left(150.9 \mathrm{MHz}, \mathrm{C}_{2} \mathrm{D}_{2} \mathrm{Cl}_{4}\right)$. 


\section{TAA-Tips}

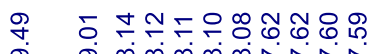

क $ं \infty \infty \infty \infty \infty N+N$

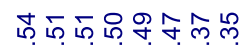

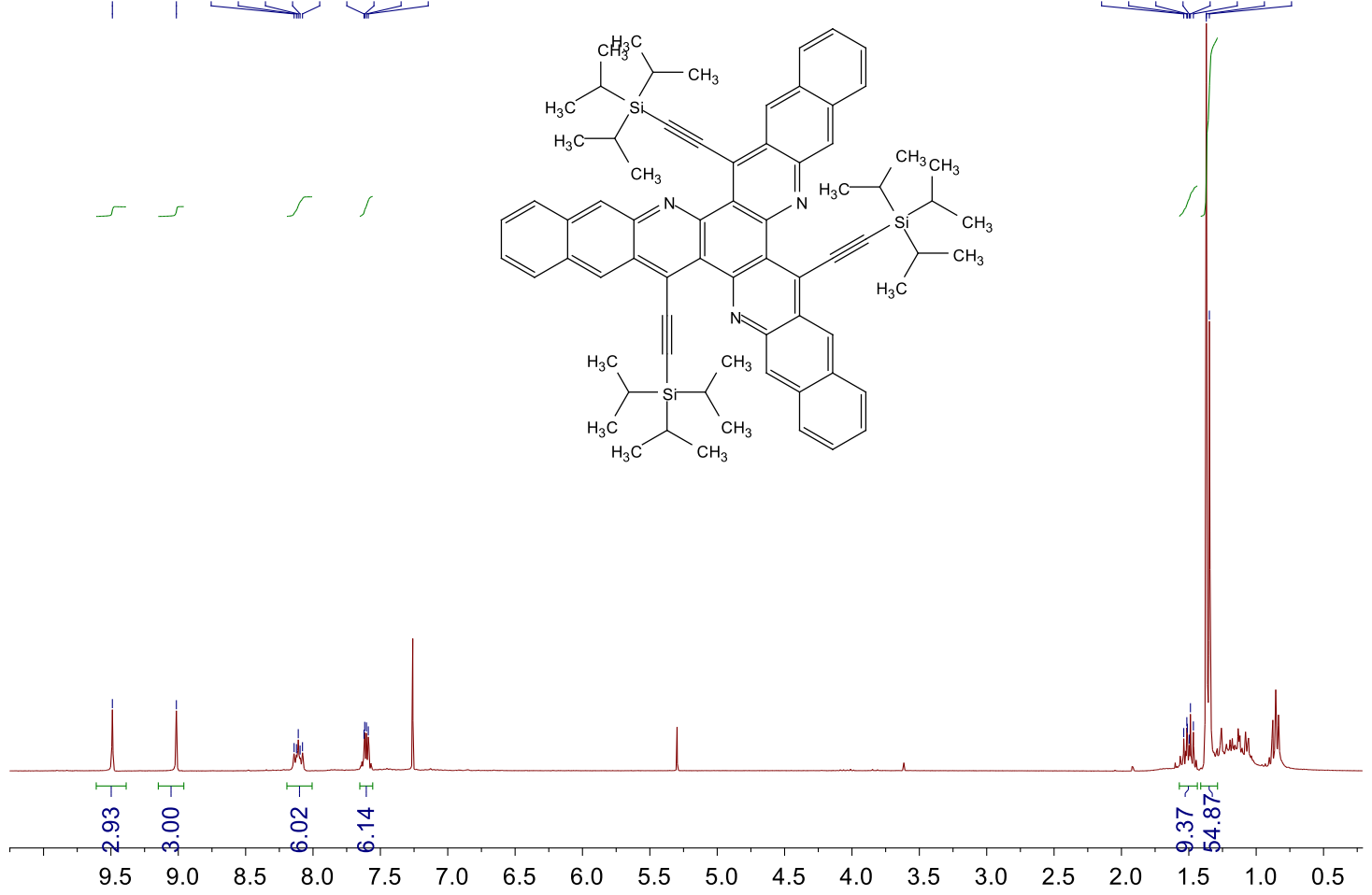

年

Figure S-F.8: ${ }^{1} \mathrm{H}$ NMR Spectrum (300 $\left.\mathrm{MHz}, \mathrm{CDCl}_{3}\right)$.

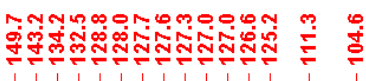

+. 


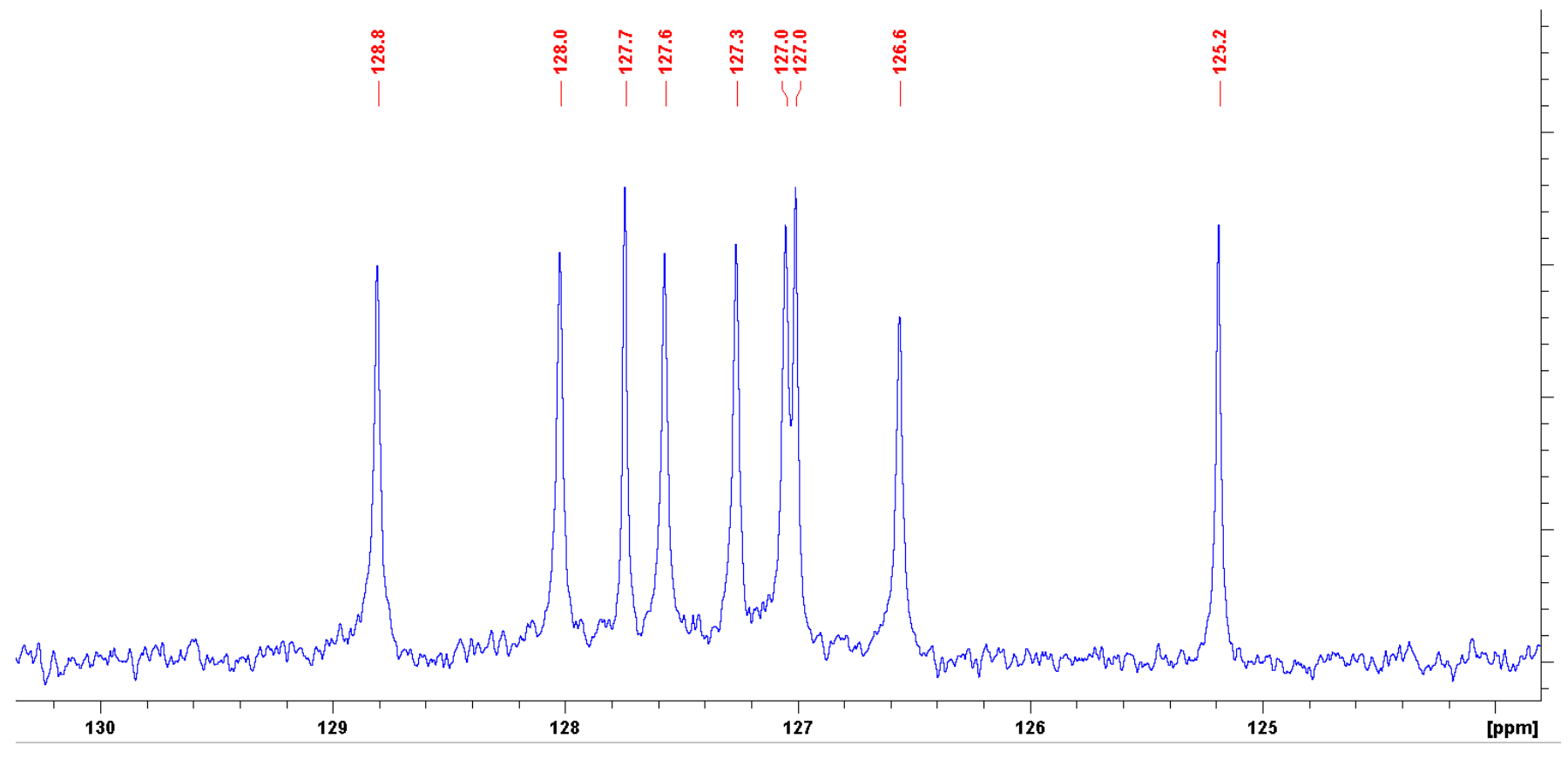

Figure S-F.9: ${ }^{13} \mathrm{C}$ NMR full Spectrum and expanded (150.9 MHz, $\left.\mathrm{C}_{2} \mathrm{D}_{2} \mathrm{Cl}_{4}\right)$. 
5. TAA-OMePh

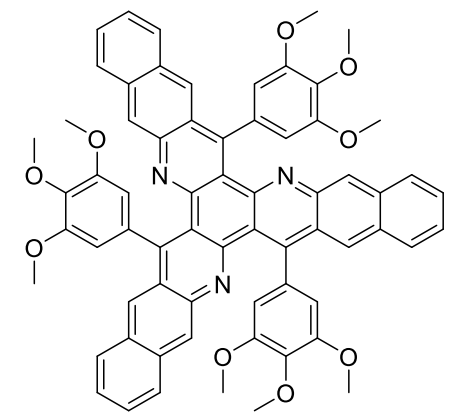

|

$\underset{i}{\stackrel{\infty}{\infty}} \stackrel{\infty}{i}$

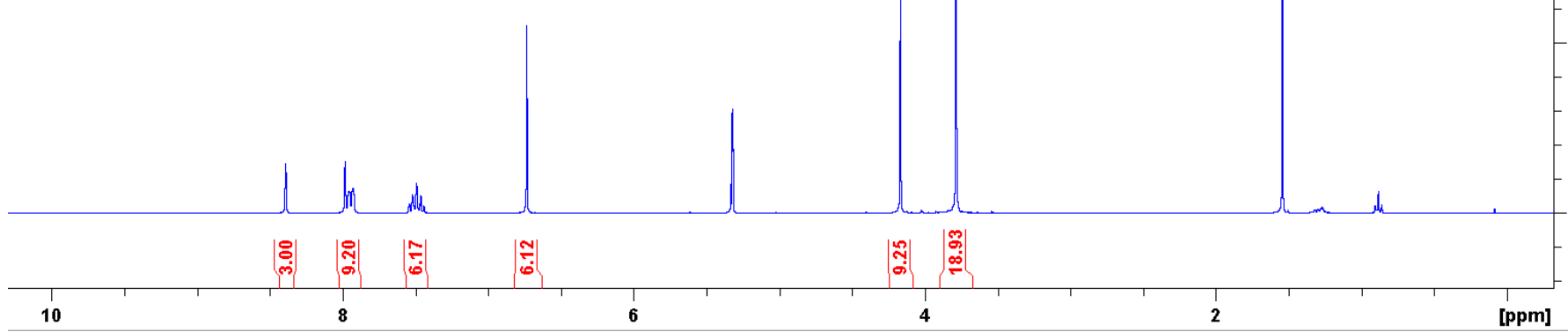

Figure S-F.10: ${ }^{1} \mathrm{H}$ NMR Spectrum (300 $\left.\mathrm{MHz}, \mathrm{CD}_{2} \mathrm{Cl}_{2}\right)$.

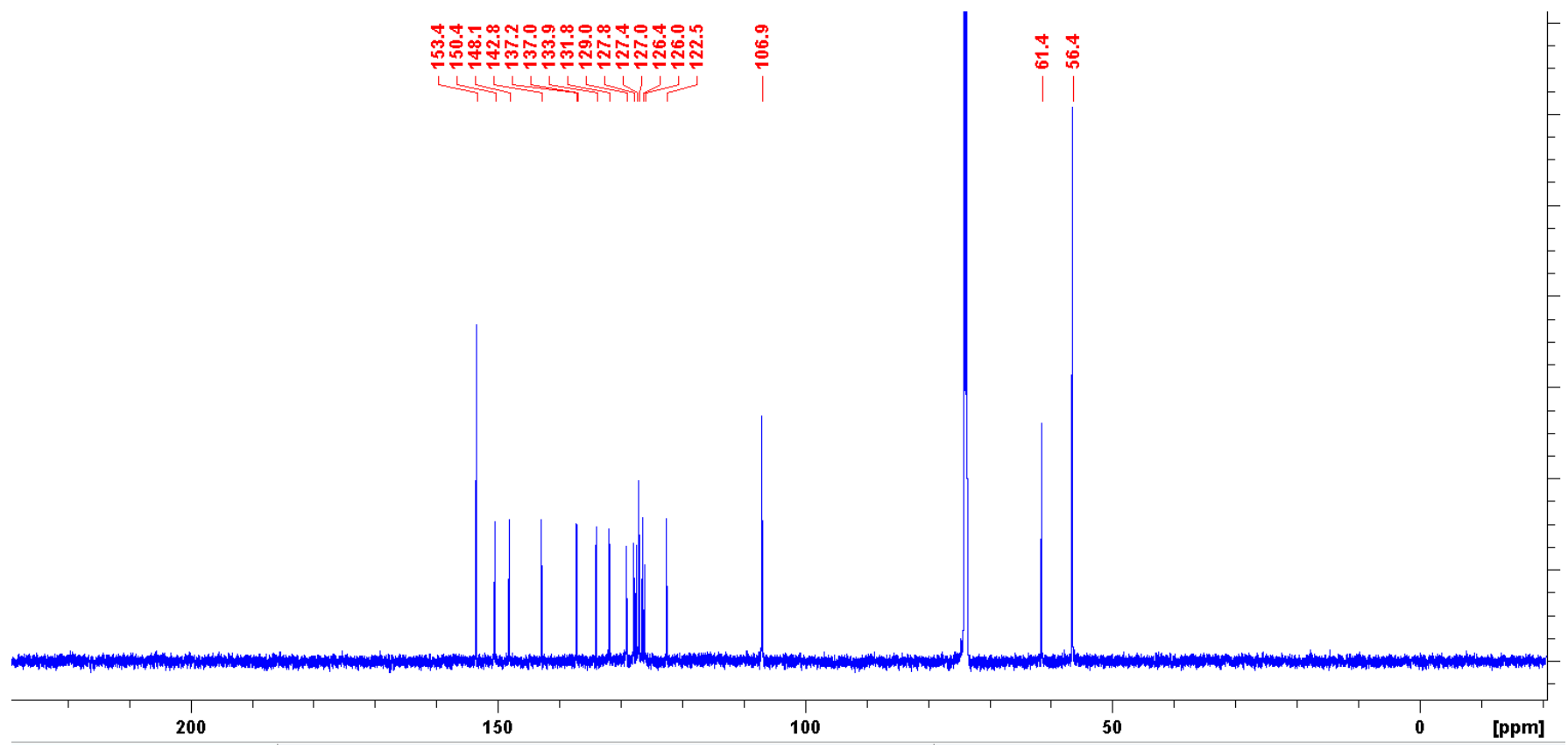

Figure S-F.11: ${ }^{13} \mathrm{C}$ NMR Spectrum, (150.9 MHz, $\left.\mathrm{C}_{2} \mathrm{D}_{2} \mathrm{Cl}_{4}\right)$. 


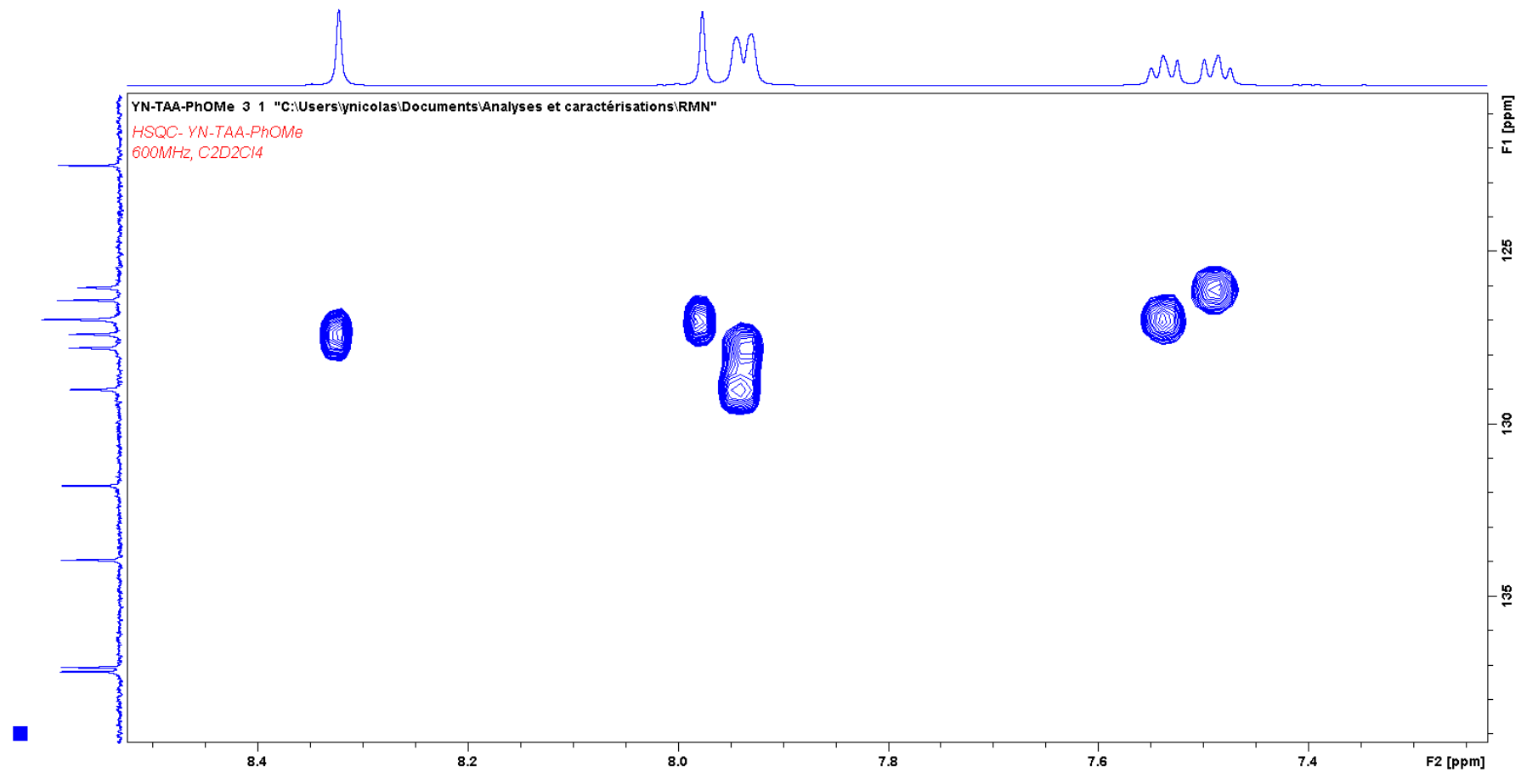

Figure S-F.12: $\mathrm{HSQC}$ NMR Spectrum, $\left({ }^{1} \mathrm{H} 600 \mathrm{MHz}, \mathrm{C}_{2} \mathrm{D}_{2} \mathrm{Cl}_{4}\right)$. 


\section{TAA-tBuPh}
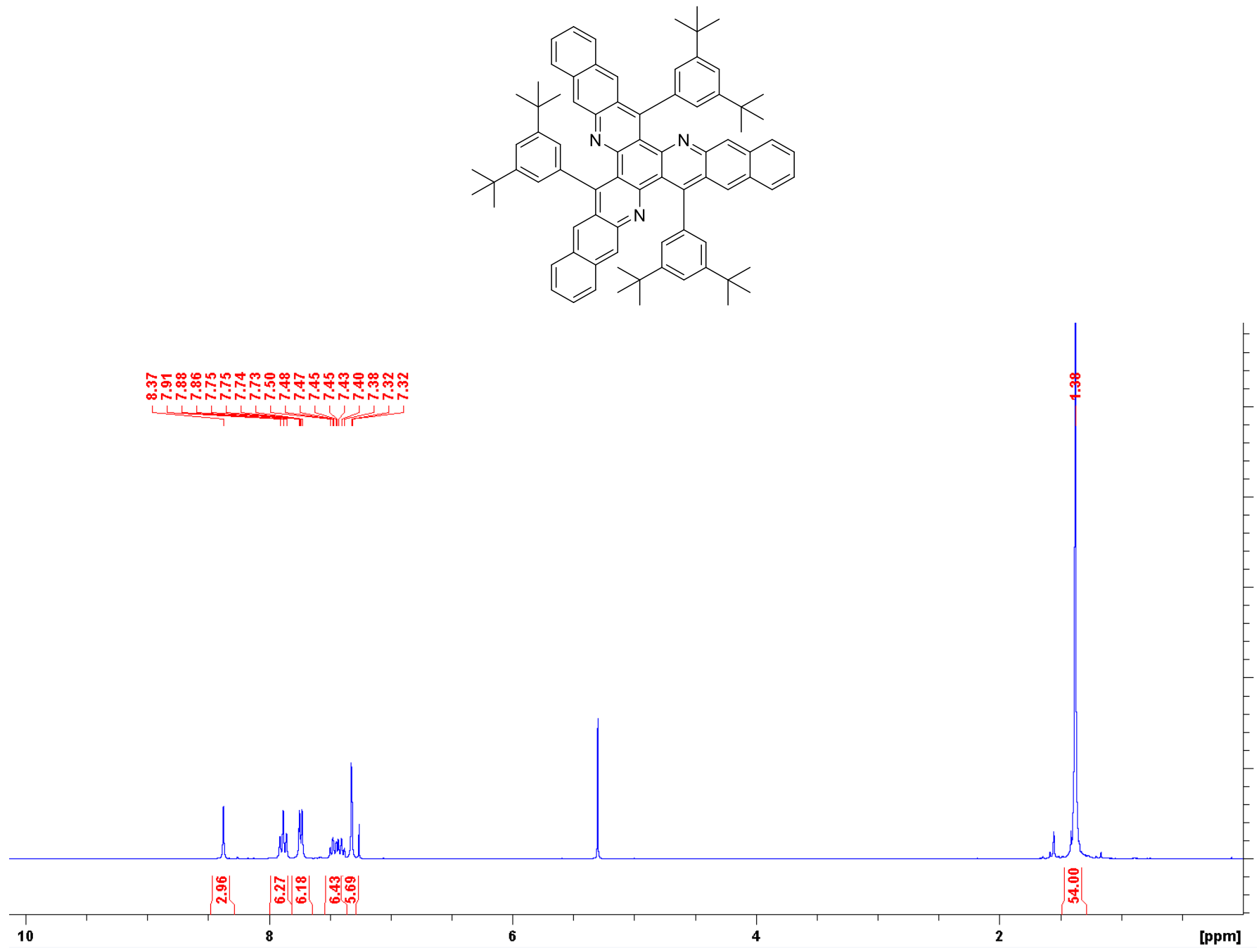

Figure S-F.13: ${ }^{1} \mathrm{H}$ NMR Spectrum $\left(300 \mathrm{MHz}, \mathrm{CDCl}_{3}\right)$. 


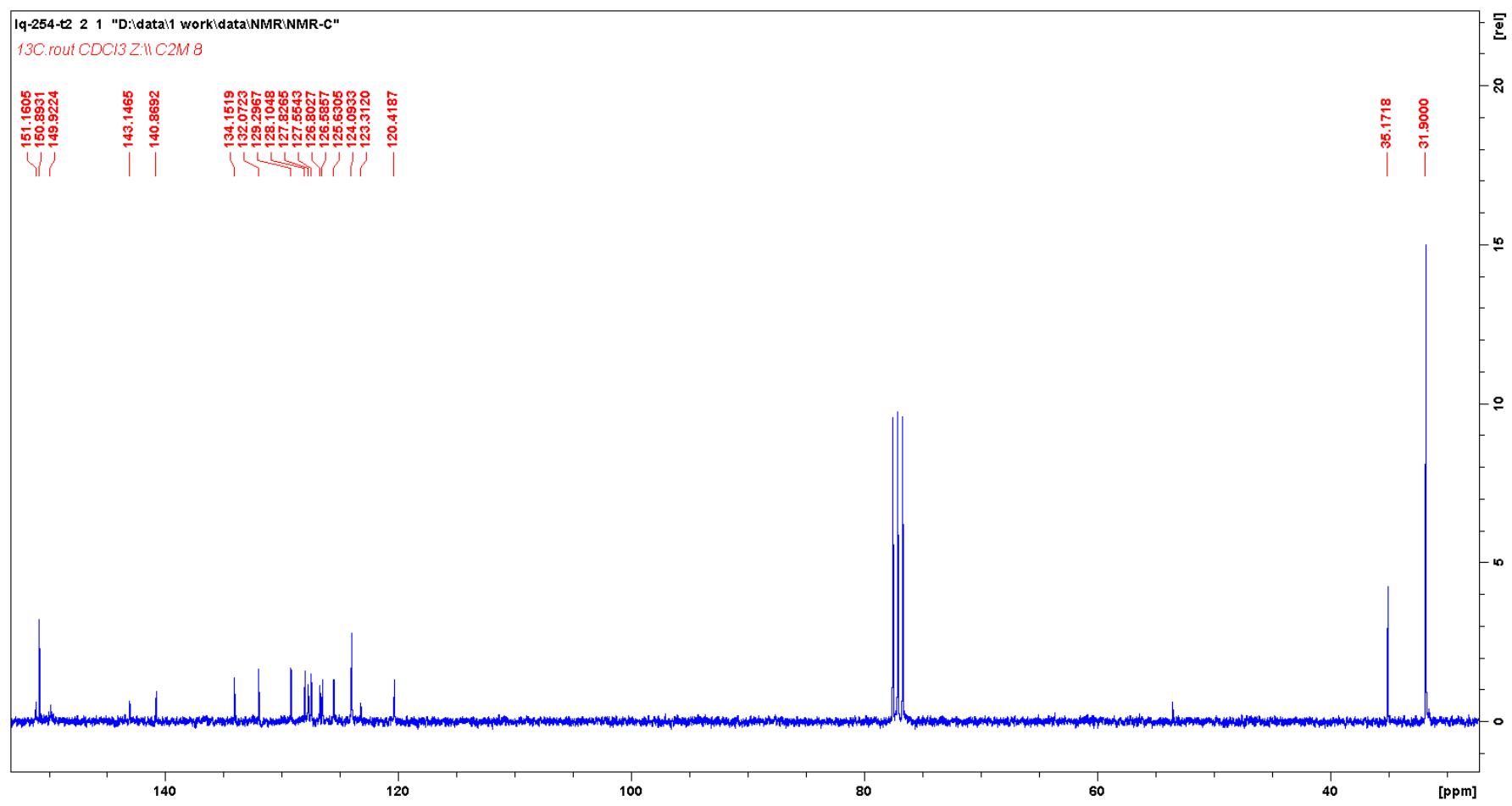

Figure S-F.14: ${ }^{13} \mathrm{C}$ NMR Spectrum $\left(75 \mathrm{MHz}, \mathrm{CDCl}_{3}\right)$. 
7. TAA-CF3Ph
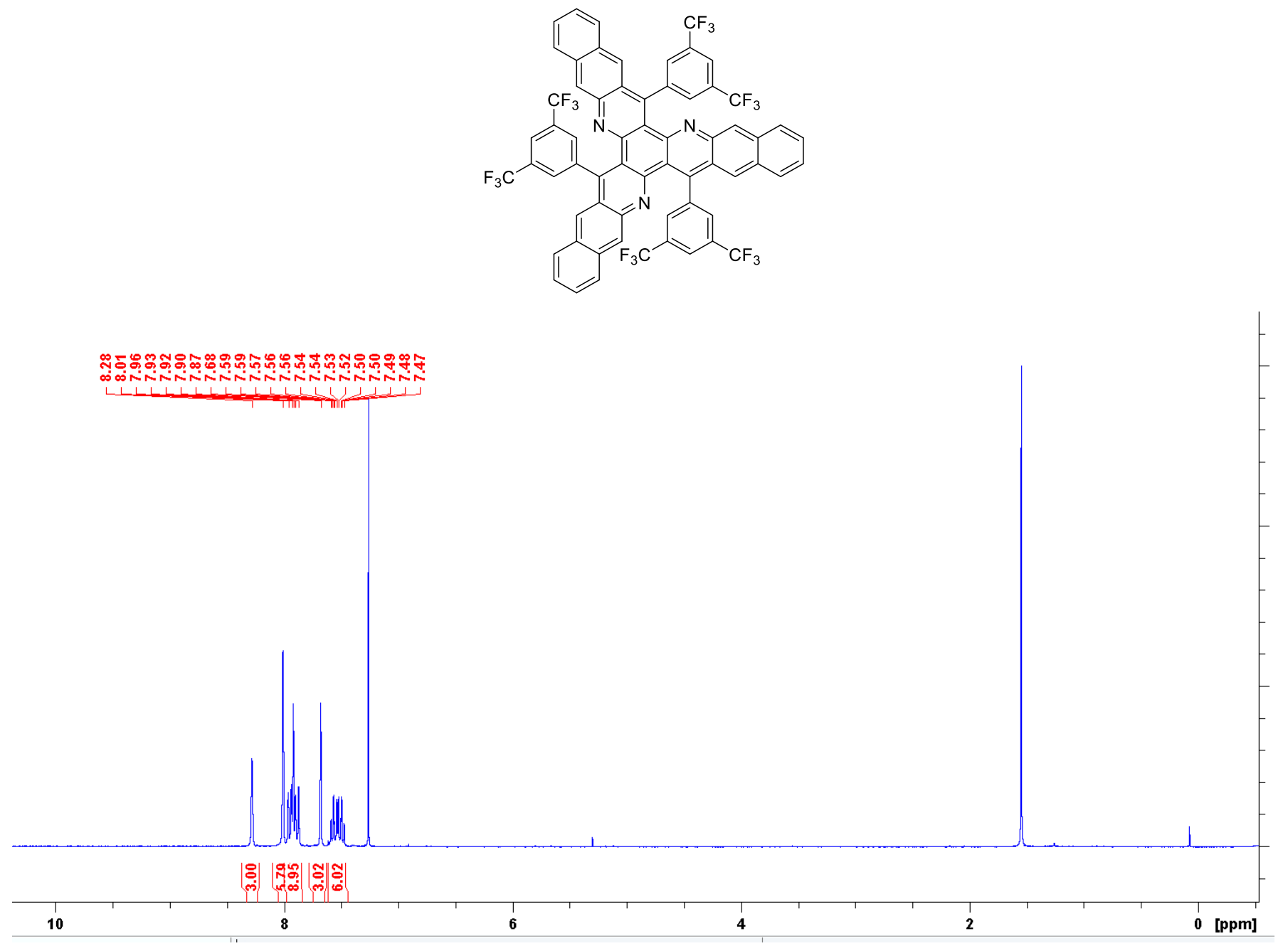

Figure S-F.15: ${ }^{1} \mathrm{H}$ NMR Spectrum (300 MHz, $\left.\mathrm{CDCl}_{3}\right)$. 

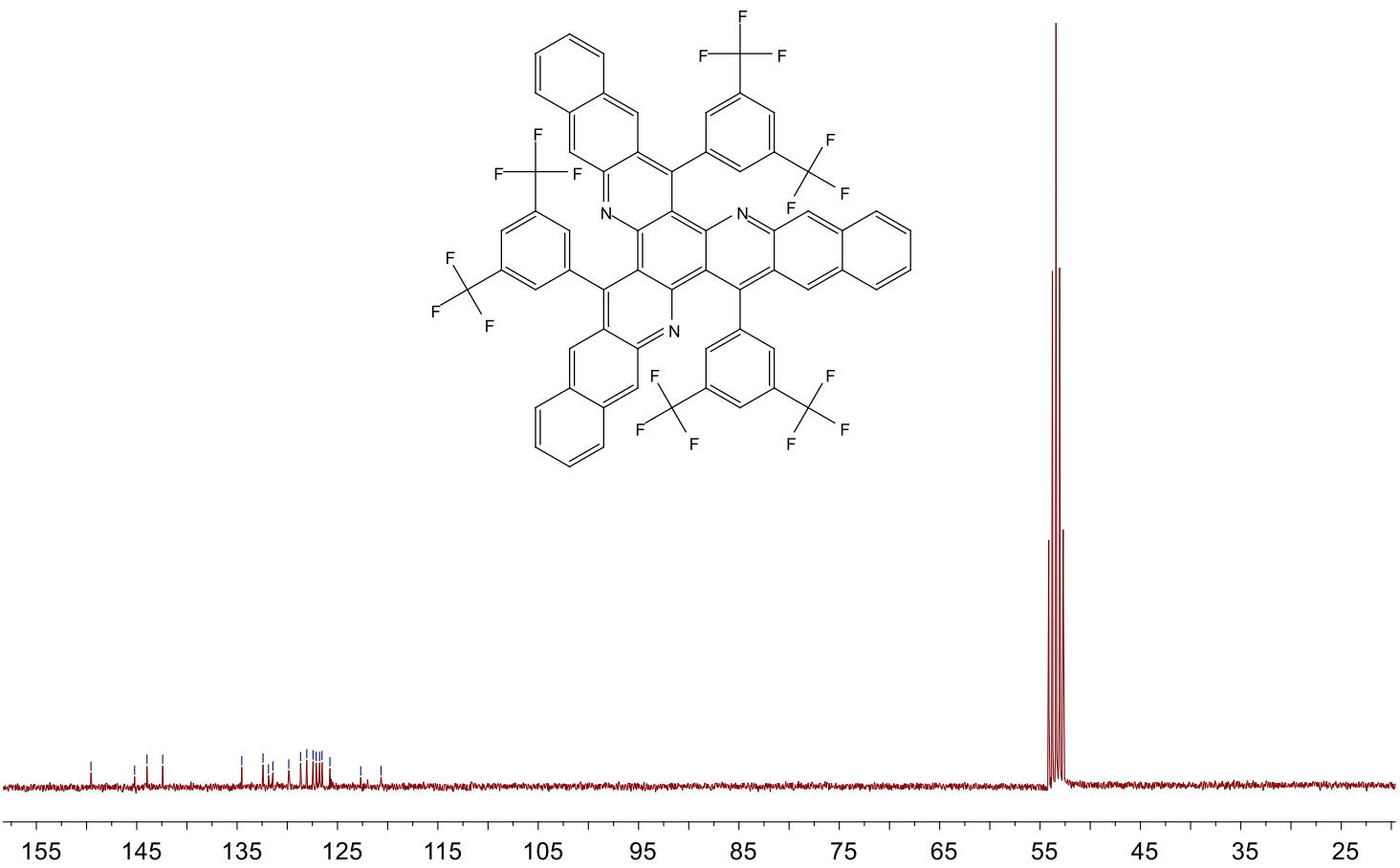

Figure S-F.16: ${ }^{13} \mathrm{C}$ NMR Spectrum $\left(75 \mathrm{MHz}, \mathrm{CD}_{2} \mathrm{Cl}_{2}\right)$. 
8. 2-amino-N-methoxy-N-methyl-3-naphthamide

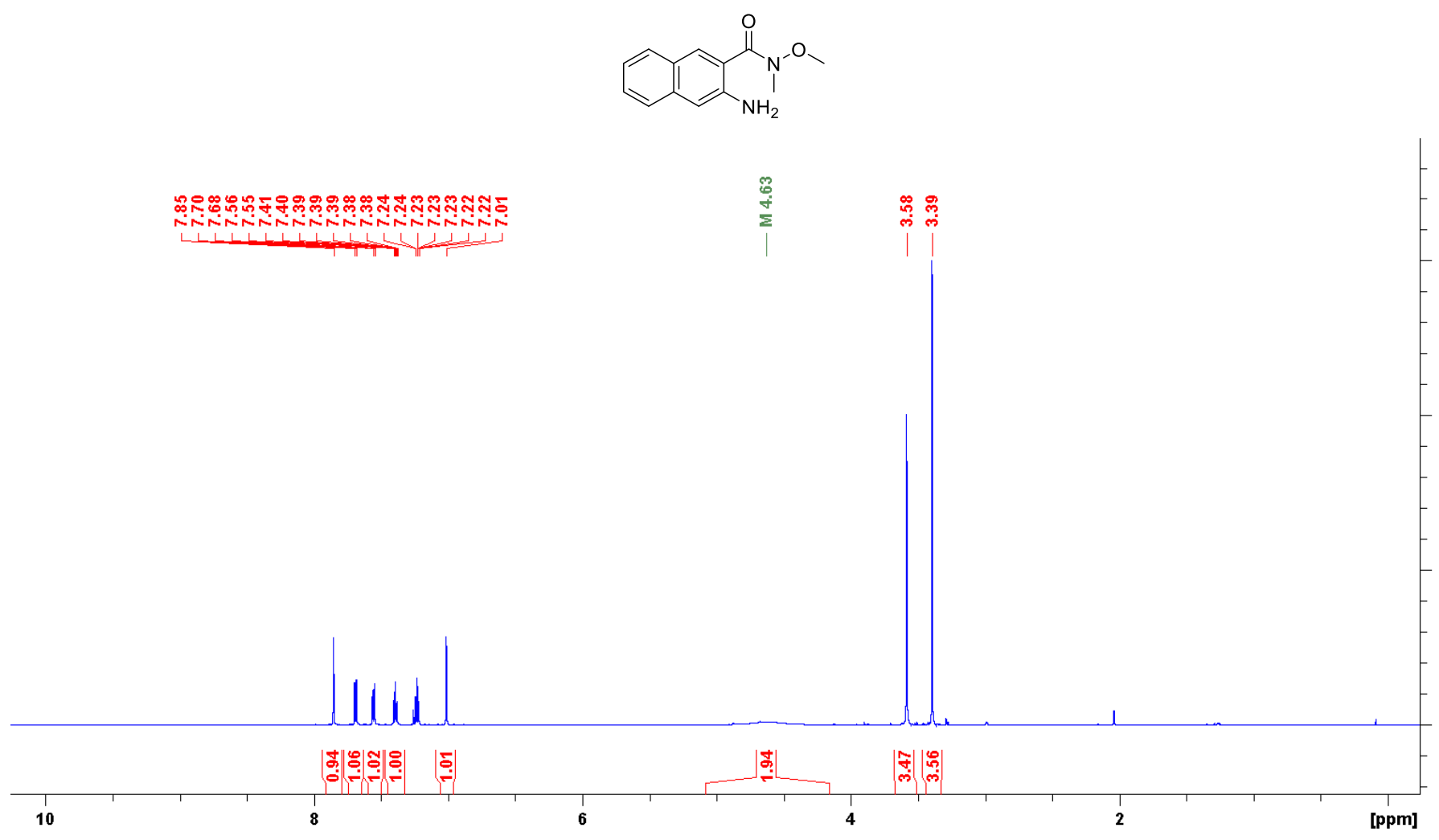

Figure S-F.17: ${ }^{1} \mathrm{H}$ NMR Spectrum $\left(600 \mathrm{MHz}, \mathrm{CDCl}_{3}\right)$.

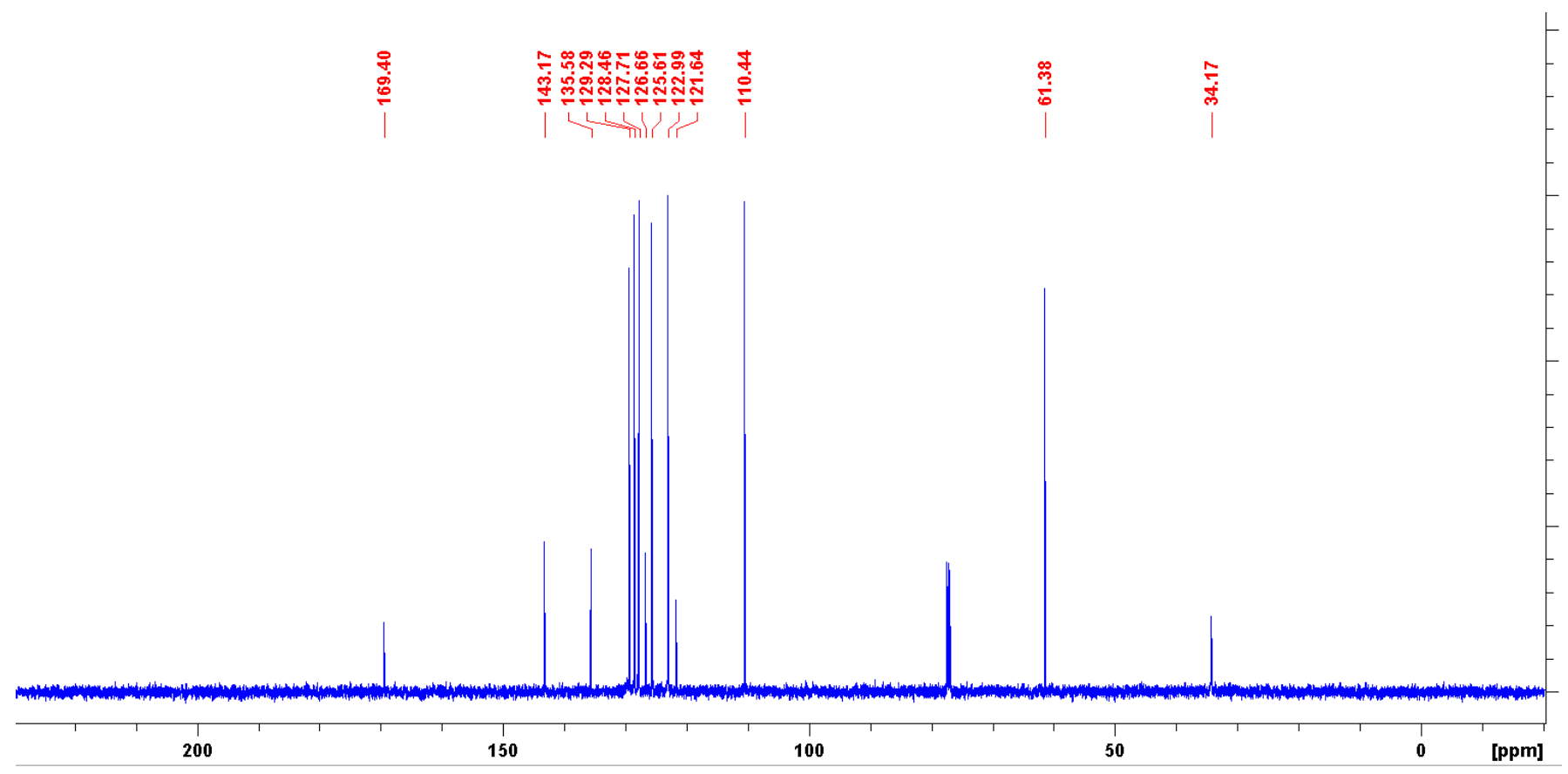

Figure S-F.18: ${ }^{13} \mathrm{C}$ NMR Spectrum $\left(150 \mathrm{MHz}, \mathrm{CDCl}_{3}\right)$. 
9. 2-amino-3-benzoylnaphthalene<smiles>Nc1cc2ccccc2cc1C(=O)c1ccccc1</smiles>

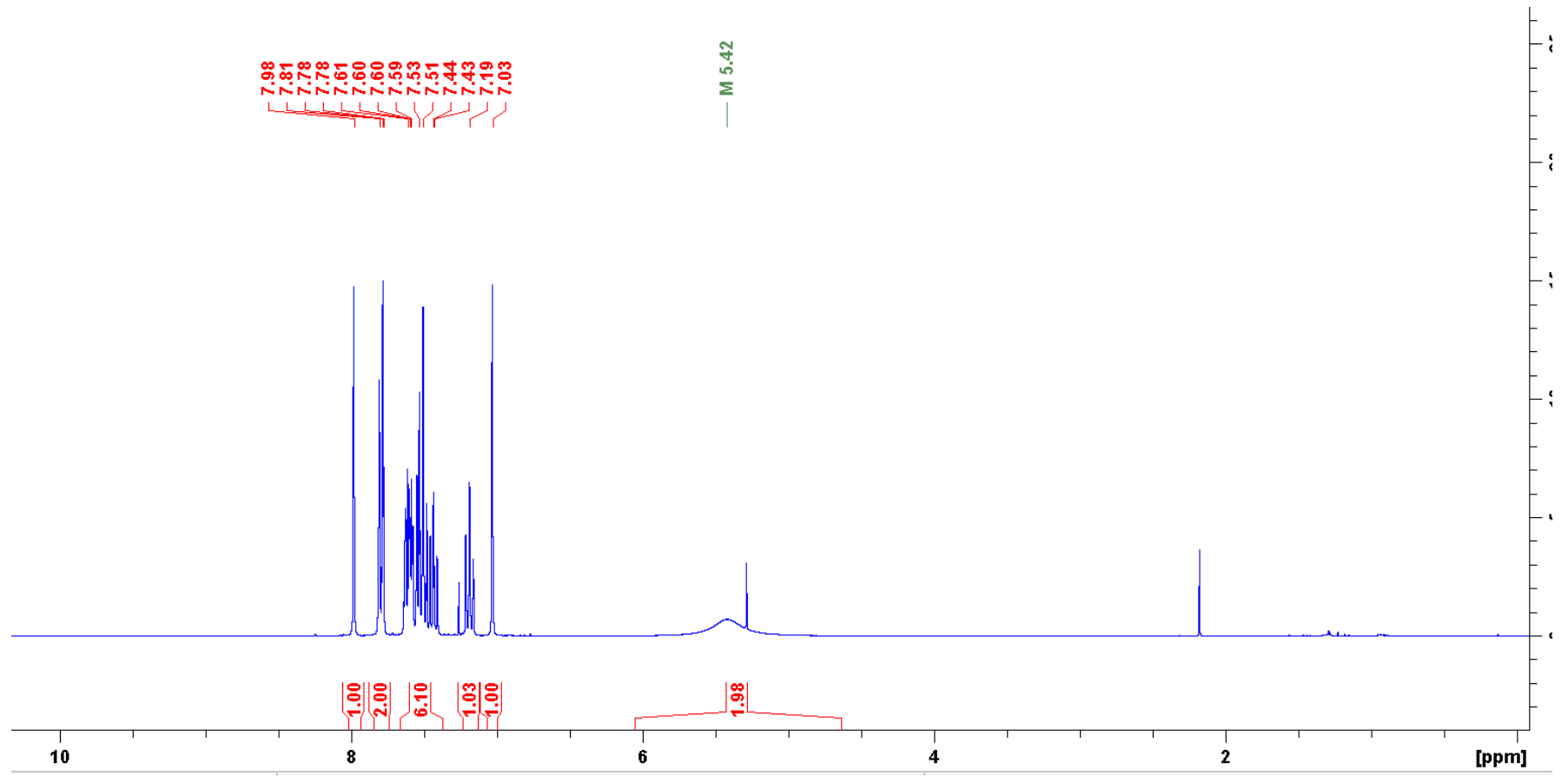

Figure S-F.19: ${ }^{1} \mathrm{H}$ NMR Spectrum (300 MHz, $\left.\mathrm{CDCl}_{3}\right)$.

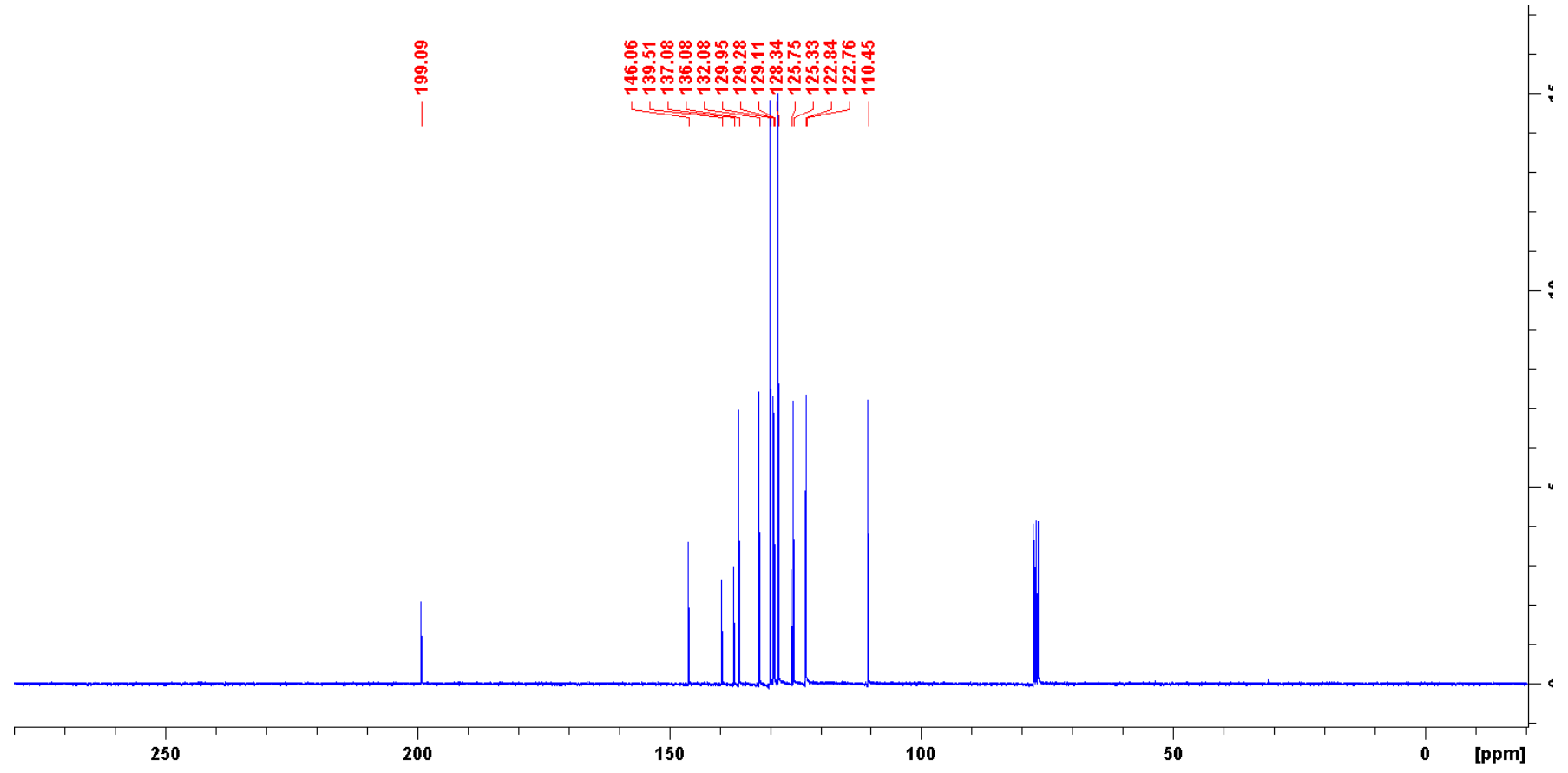

Figure S-F.20: ${ }^{13} \mathrm{C}$ NMR Spectrum (75 $\left.\mathrm{MHz}, \mathrm{CDCl}_{3}\right)$. 
10. 1-(3-(2-aminonaphthalenyl)-3-(triisopropylsilyl)-2-propyn-1-one

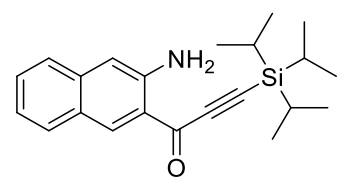

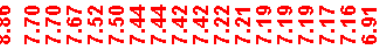

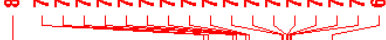

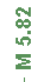

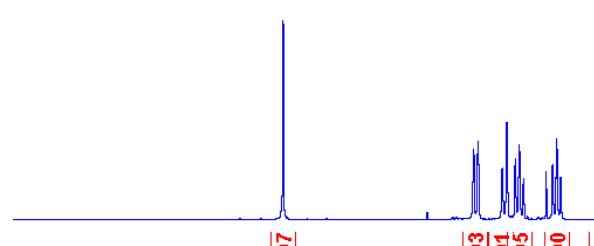

10

|⿹

Figure S-F.21: ${ }^{1} \mathrm{H}$ NMR Spectrum $\left(300 \mathrm{MHz}, \mathrm{CDCl}_{3}\right)$.

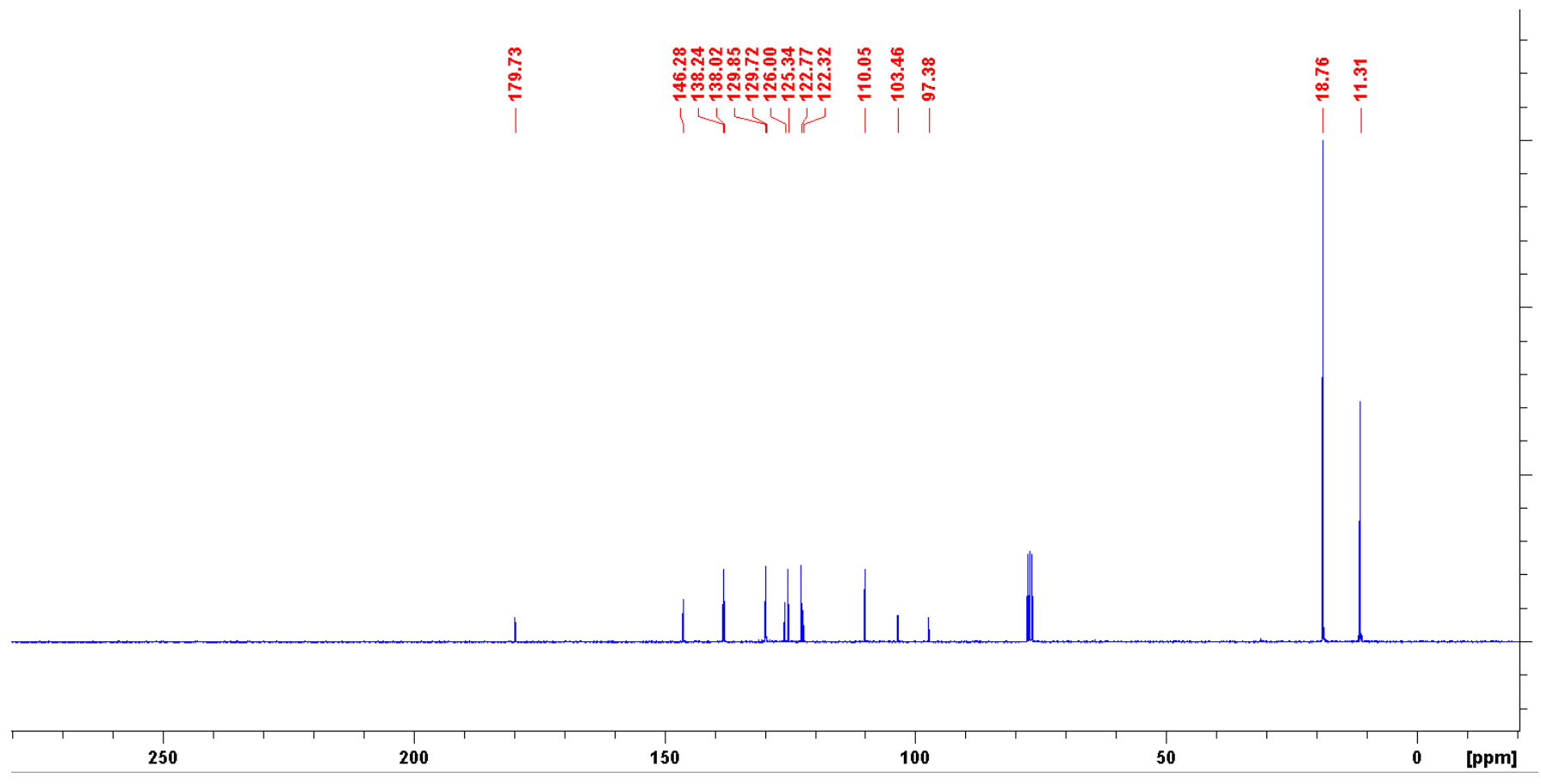

Figure S-F.22: ${ }^{13} \mathrm{C}$ NMR Spectrum $\left(75 \mathrm{MHz}, \mathrm{CDCl}_{3}\right)$. 
11. 2-amino-3-(3,4,5-trimethoxy)benzoylnaphthalene<smiles>COc1cc(C(=O)c2cc3ccccc3cc2N)c(N)c(OC)c1OC</smiles>

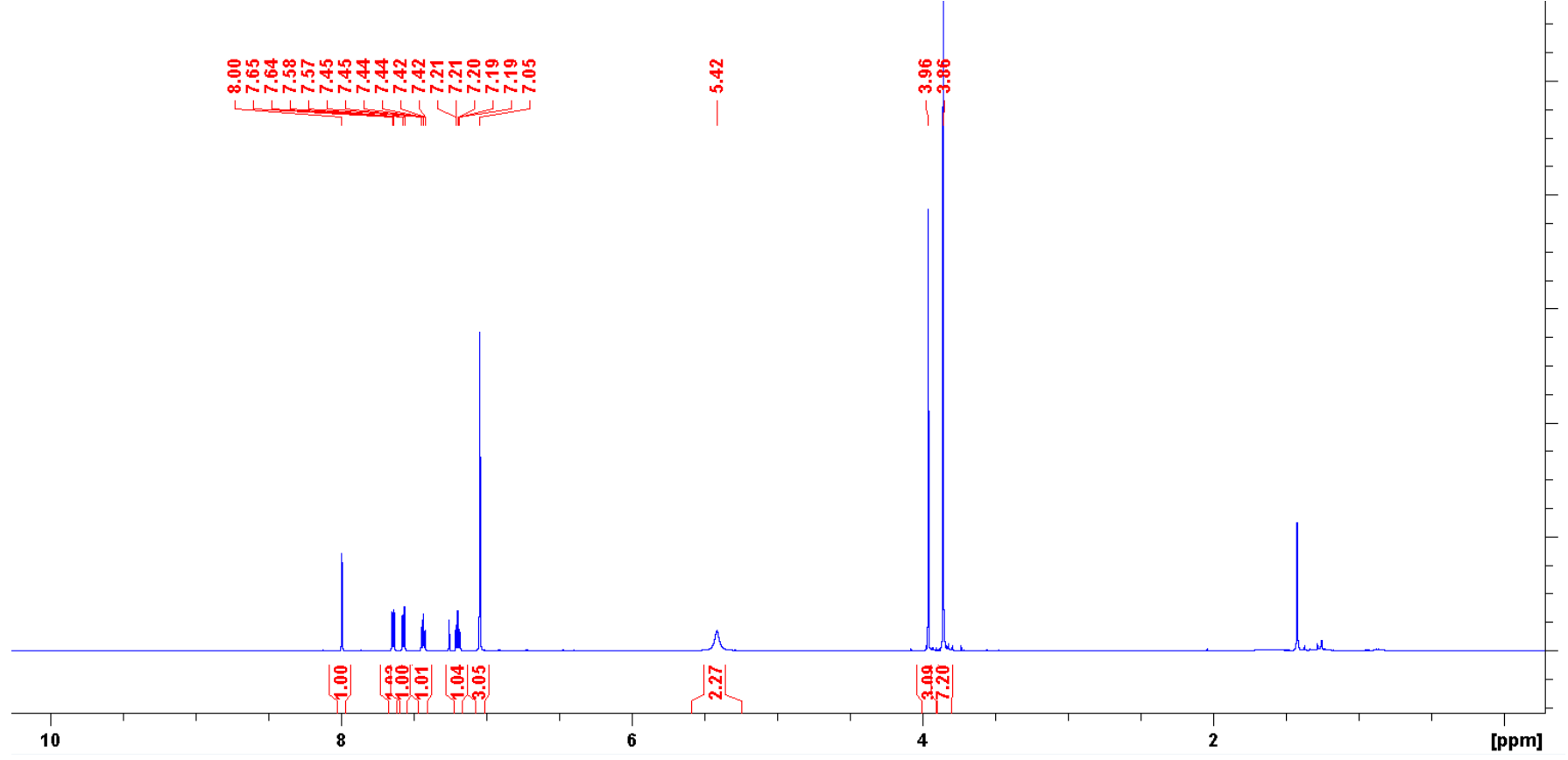

Figure S-F.23: ${ }^{1} \mathrm{H}$ NMR Spectrum $\left(600 \mathrm{MHz}, \mathrm{CDCl}_{3}\right)$.

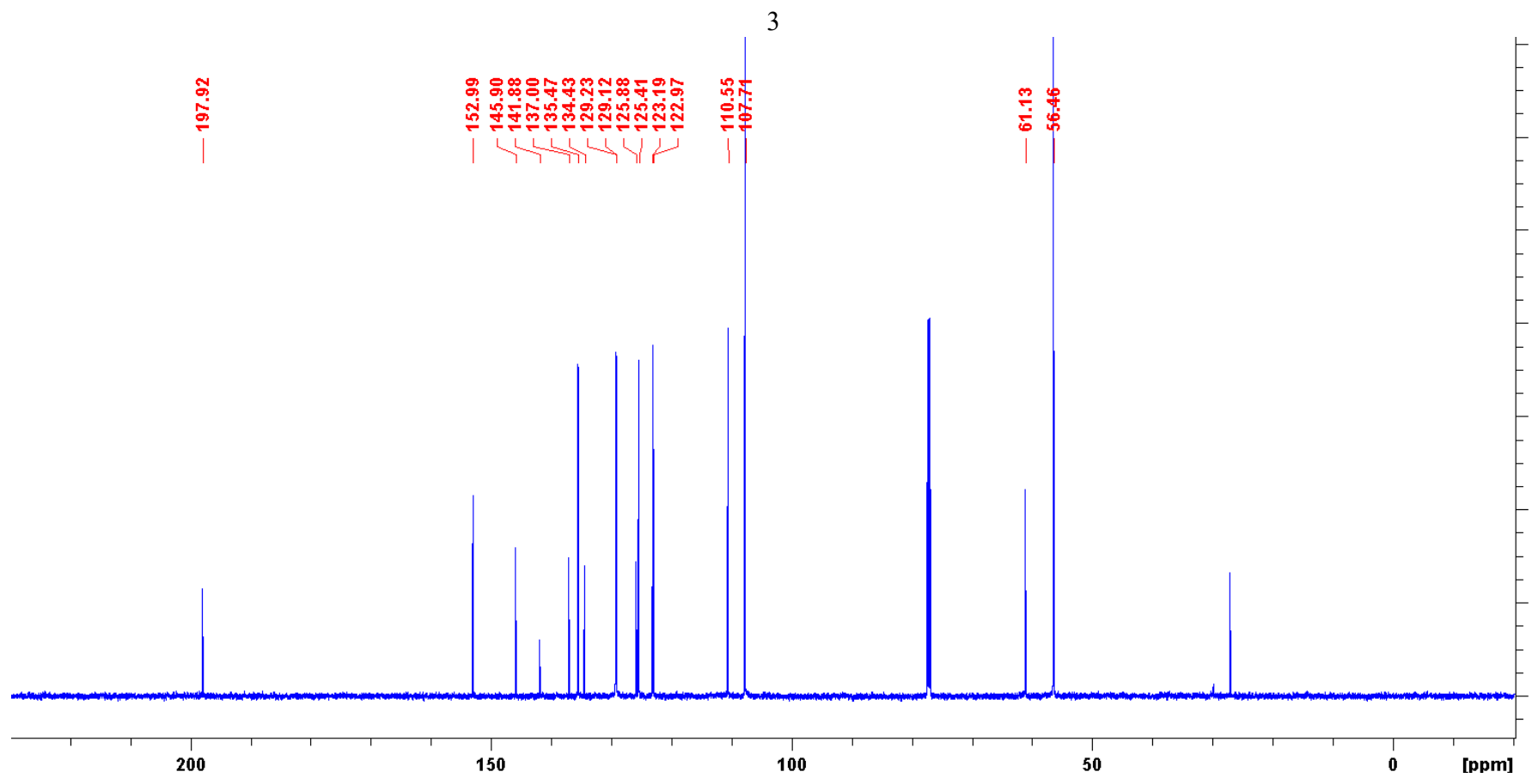

Figure S-F.24: ${ }^{13} \mathrm{C}$ NMR Spectrum (150 $\left.\mathrm{MHz}, \mathrm{CDCl}_{3}\right)$. 
12. 2-amino-3-(3,5-di-tert-butyl)benzoylnaphthalene
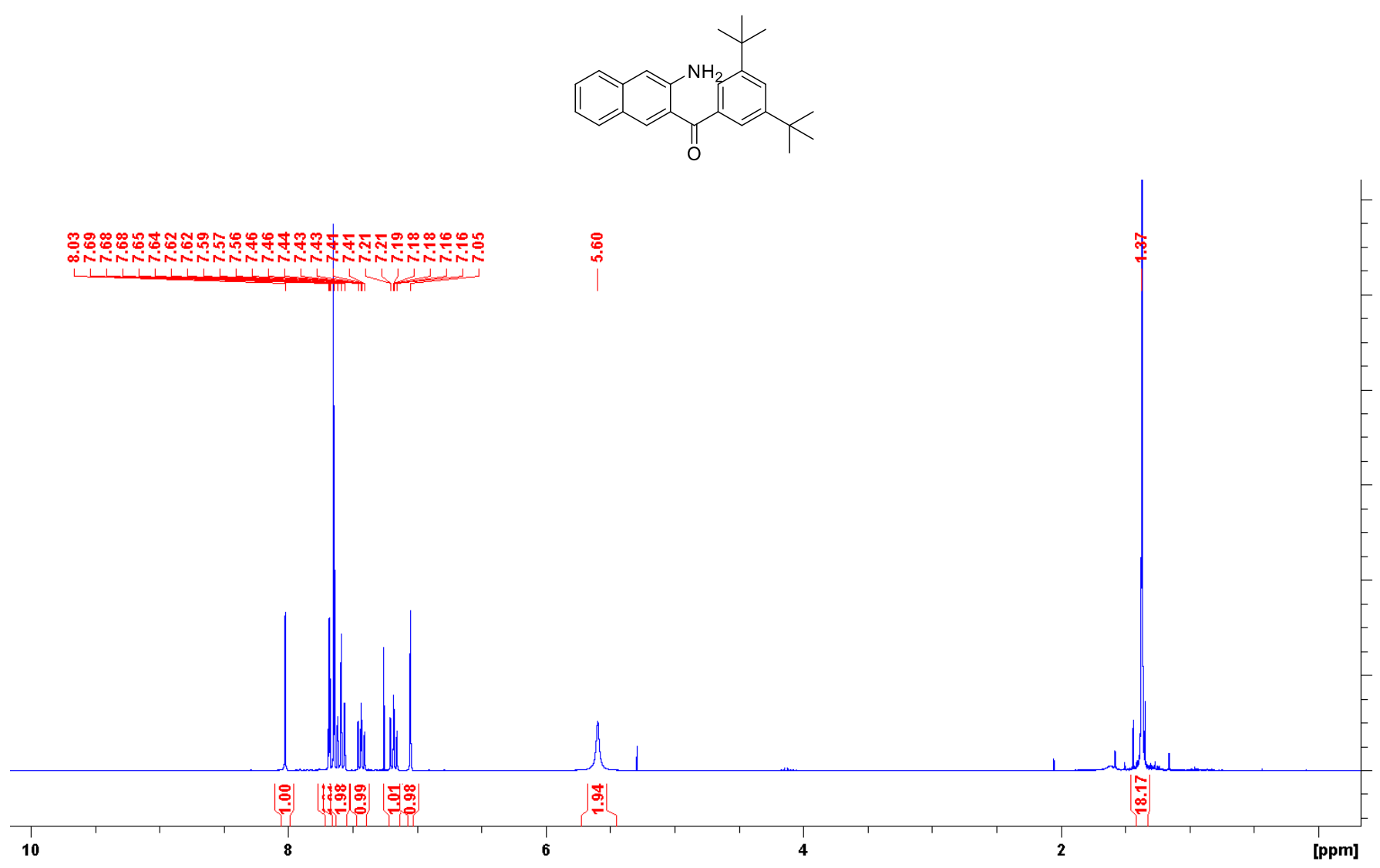

Figure S-F.25: ${ }^{1} \mathrm{H}$ NMR Spectrum $\left(300 \mathrm{MHz}, \mathrm{CDCl}_{3}\right)$.

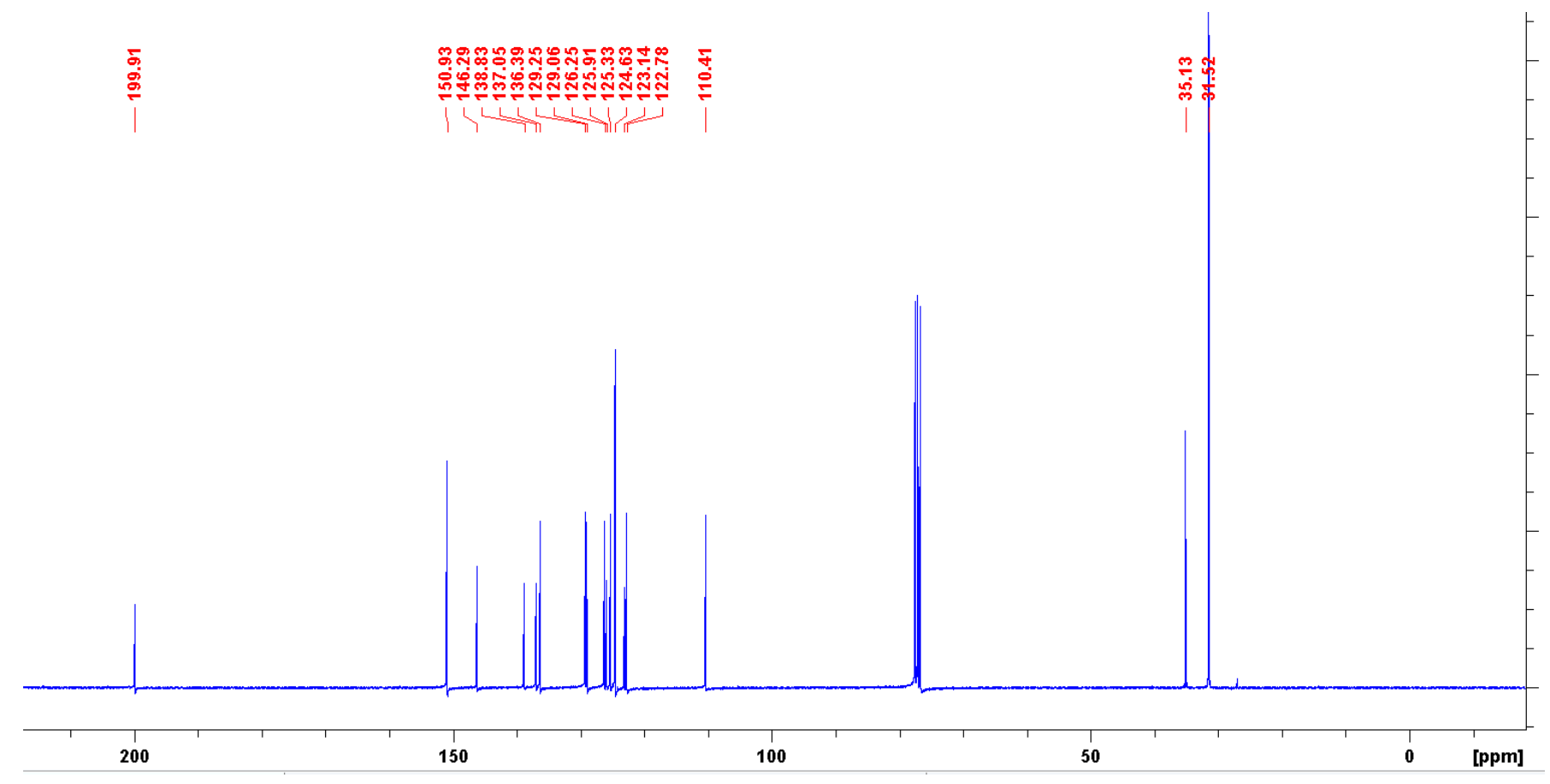

Figure S-F.26: ${ }^{13} \mathrm{C}$ NMR Spectrum $\left(75 \mathrm{MHz}, \mathrm{CDCl}_{3}\right)$. 
13. 2-amino-3-(3,5-bis(trifluoromethyl))benzoylnaphthalene
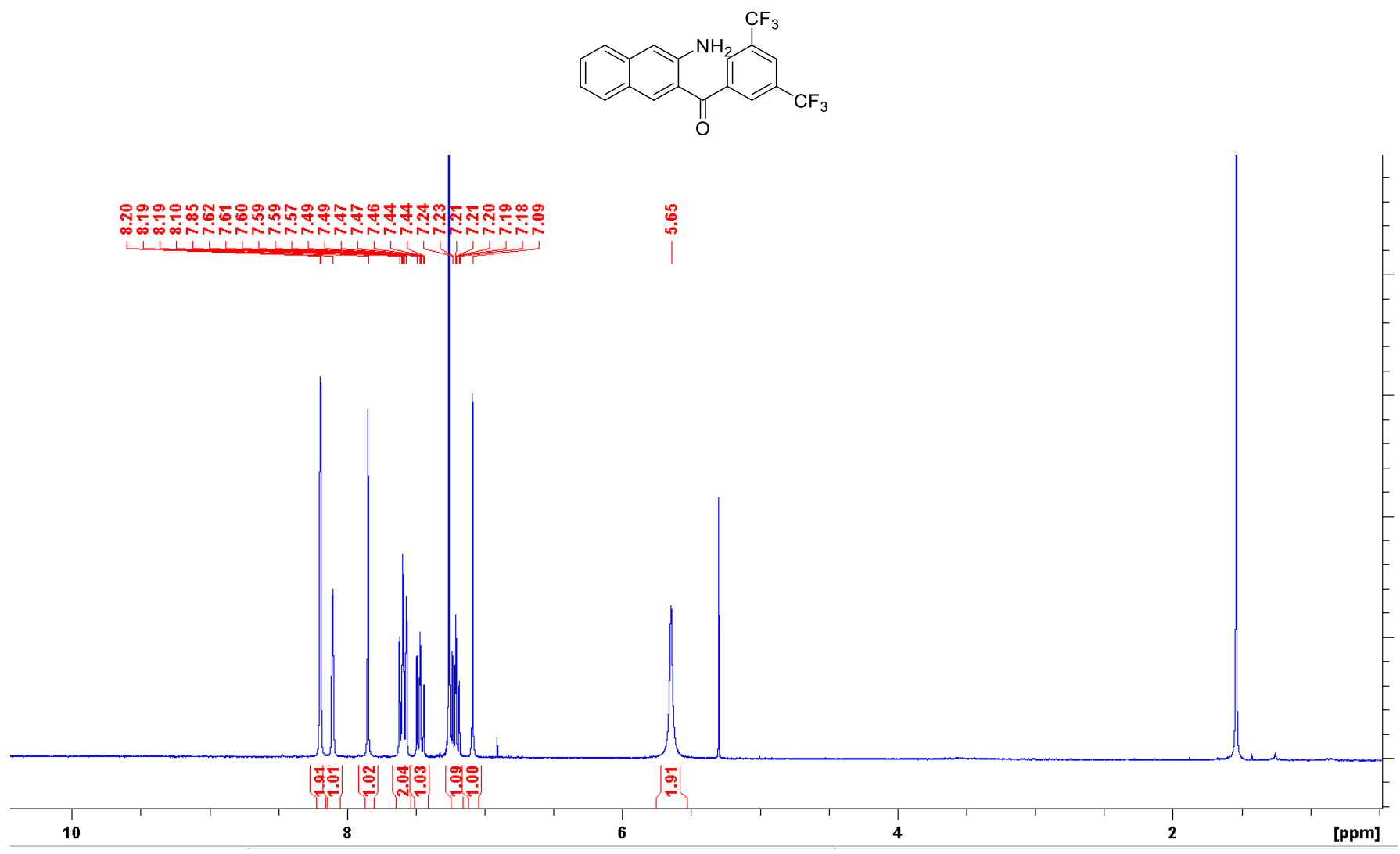

Figure S-F.27: ${ }^{1} \mathrm{H}$ NMR Spectrum (300 MHz, $\left.\mathrm{CDCl}_{3}\right)$.

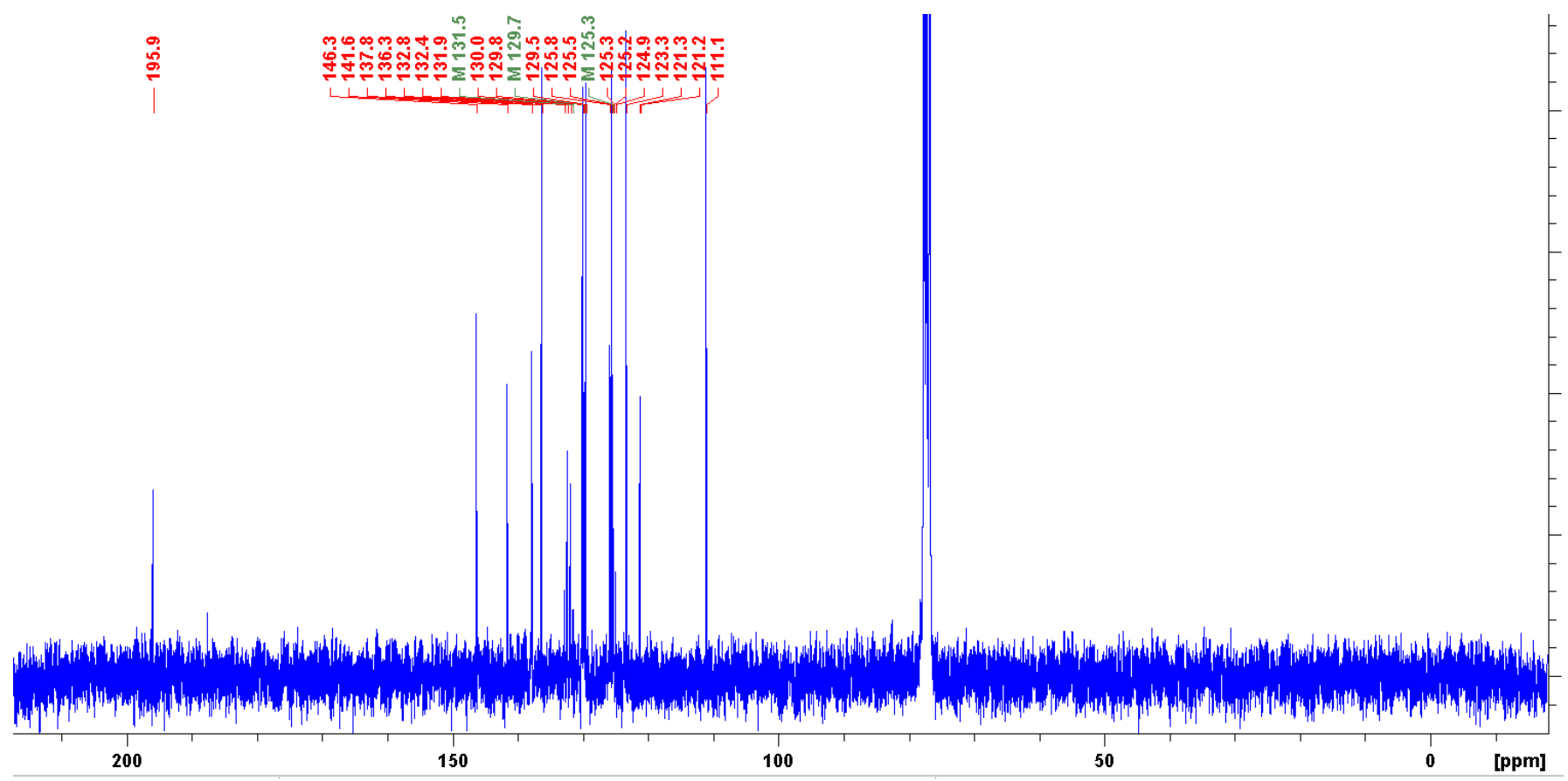




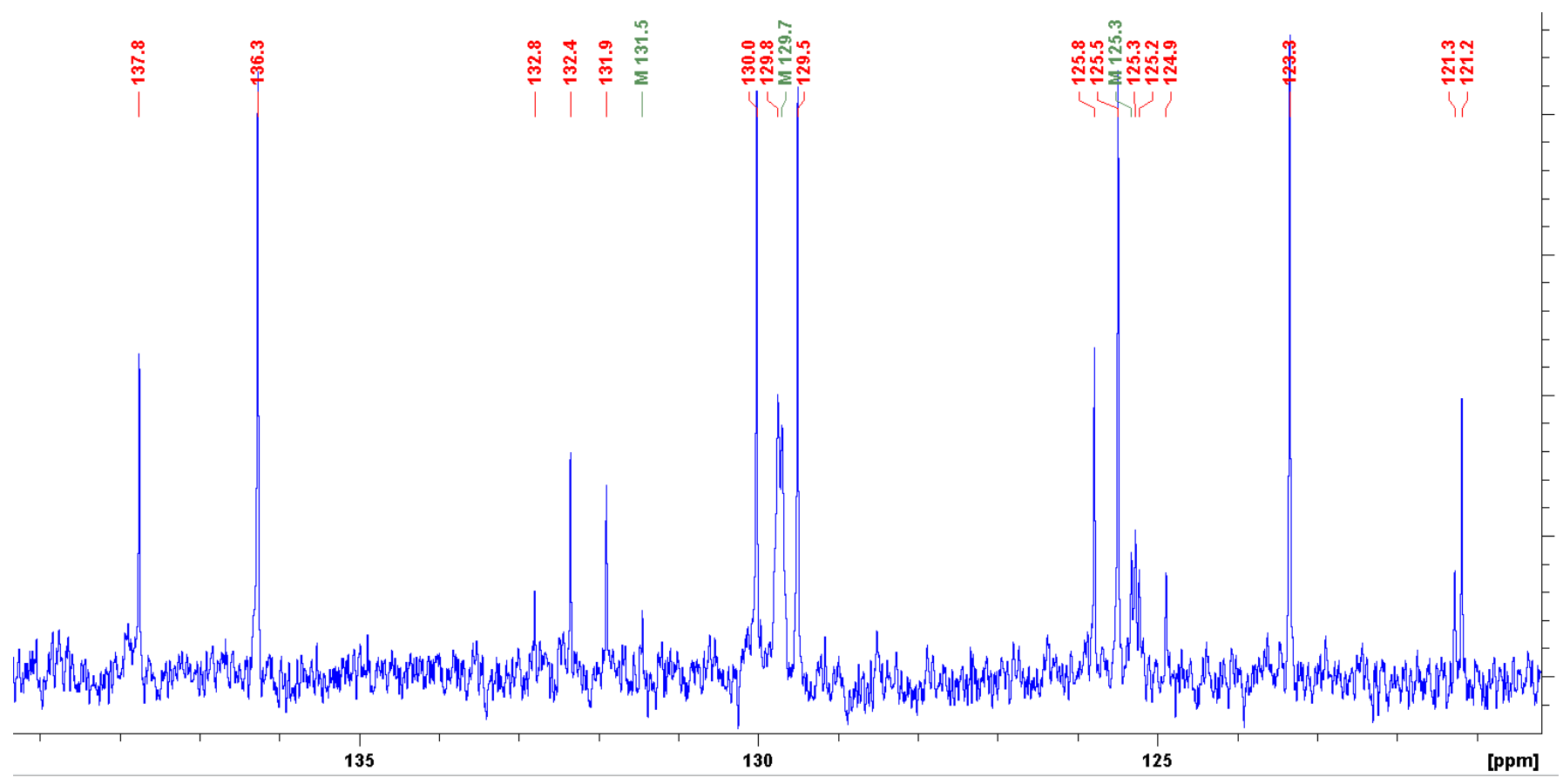

Figure S-F.28: ${ }^{13} \mathrm{C}$ NMR full Spectrum and expanded (75 $\left.\mathrm{MHz}, \mathrm{CDCl}_{3}\right)$. 


\section{2-Phenylaminobenzophenone}

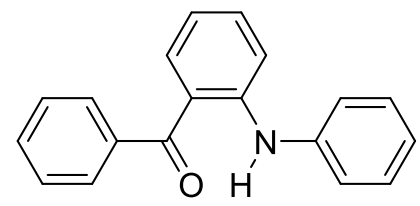

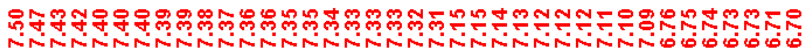

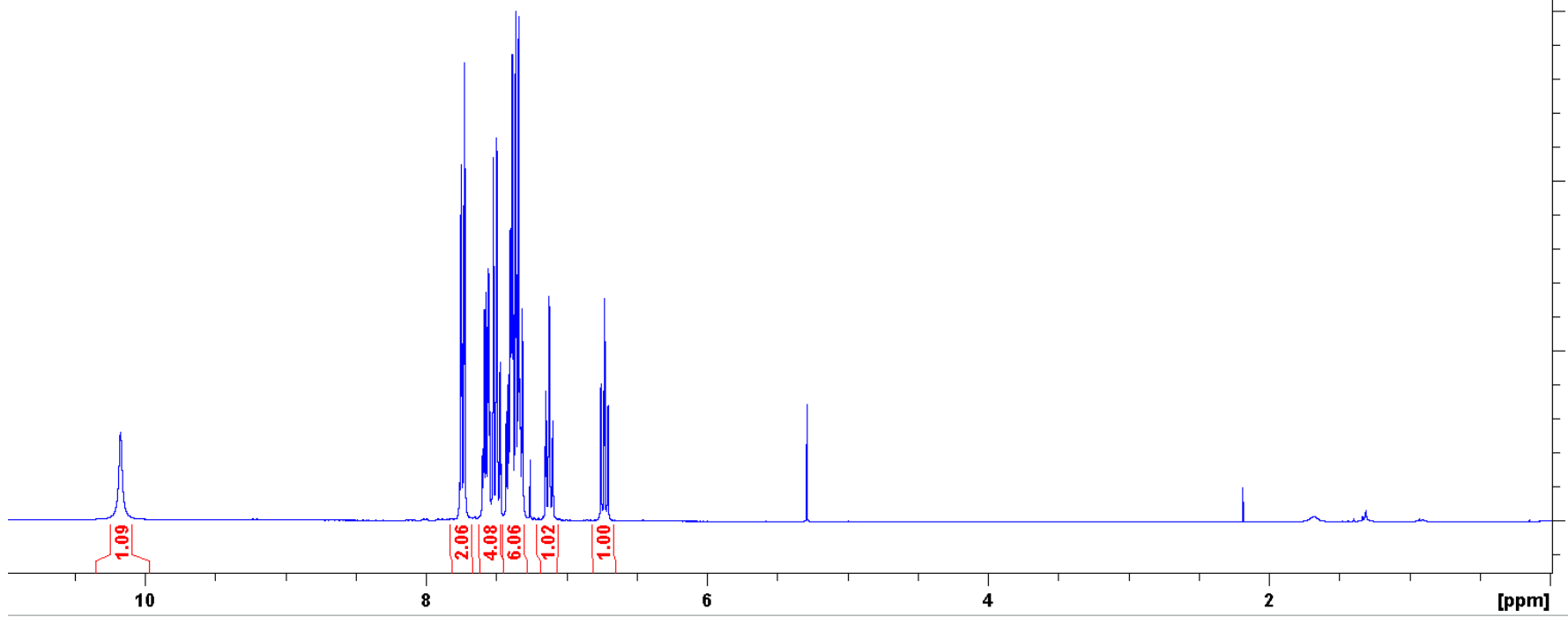

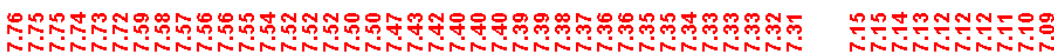

o.

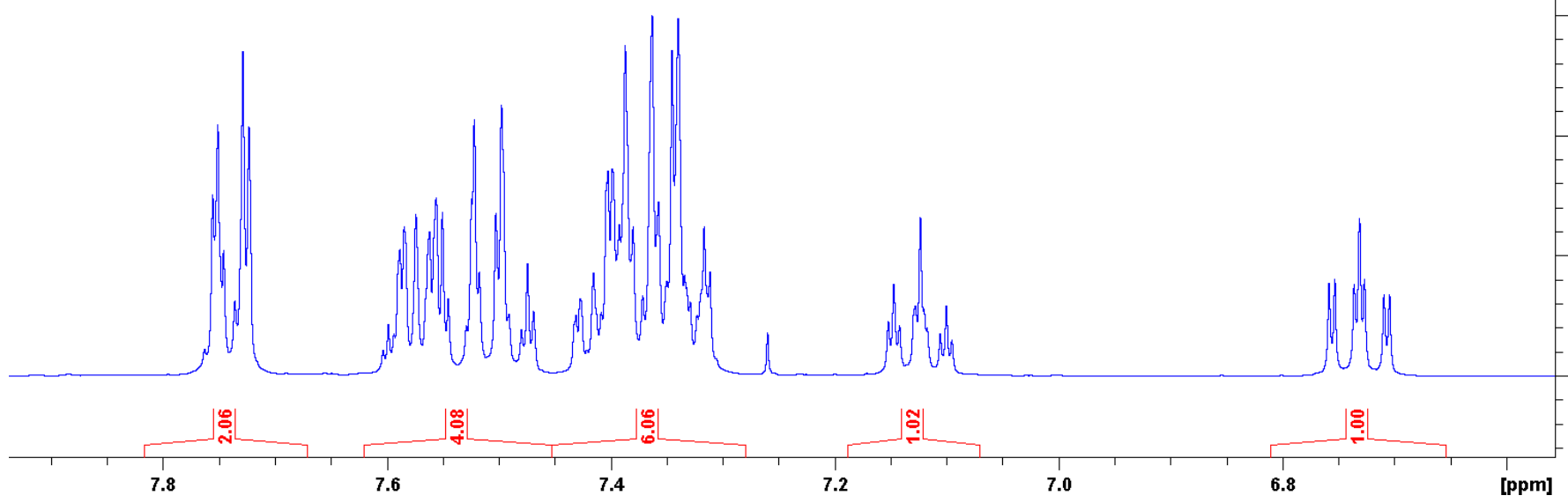

Figure S-F.29: ${ }^{1} \mathrm{H}$ NMR Spectrum $\left(300 \mathrm{MHz}, \mathrm{CDCl}_{3}\right)$. 


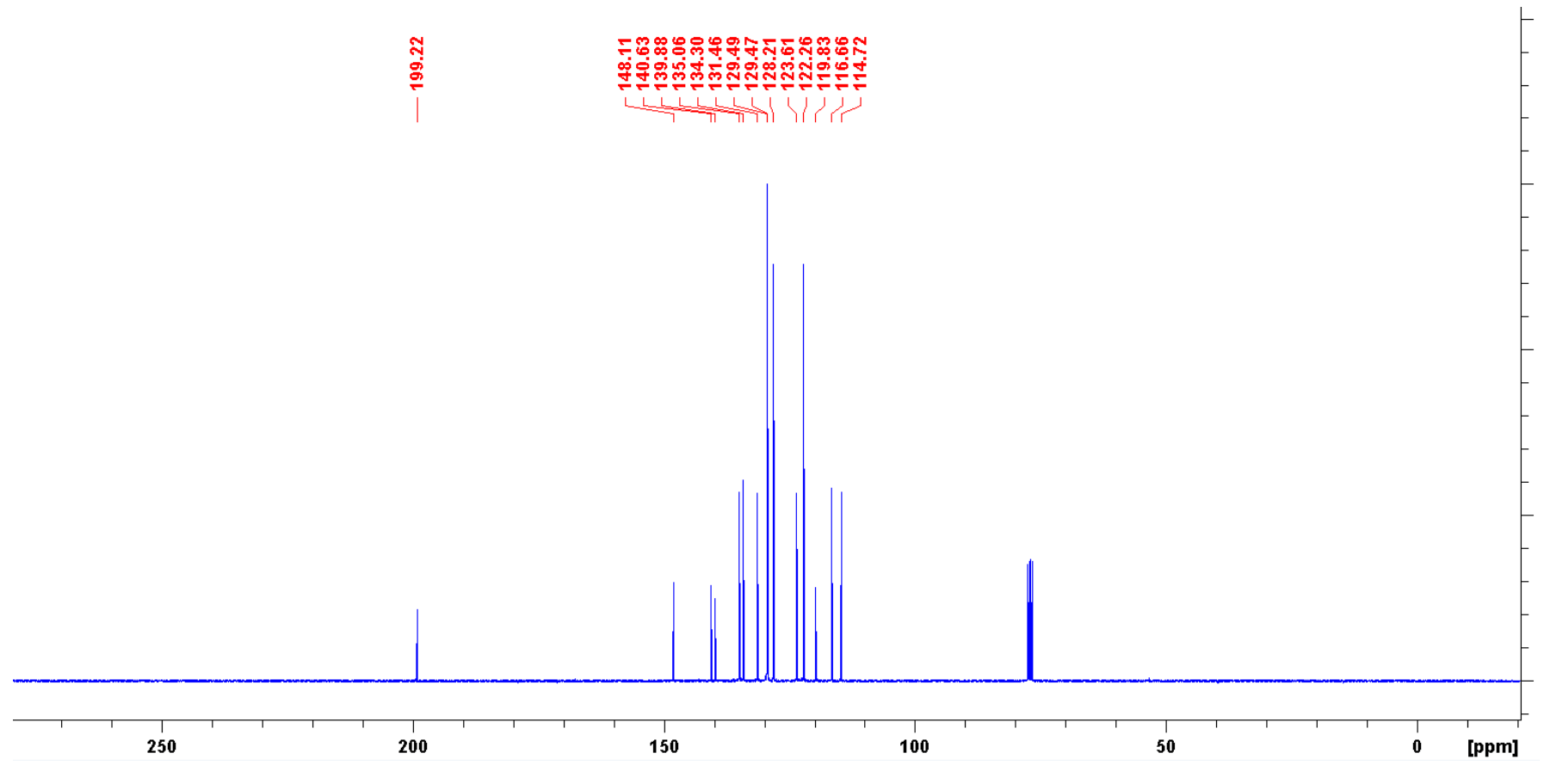

Figure S-F.30: ${ }^{13} \mathrm{C}$ NMR Spectrum $\left(75 \mathrm{MHz}, \mathrm{CDCl}_{3}\right)$. 
15. [1,4-Phenylenebis(imino-2,1-phenylene)]bis(phenylmethanone)
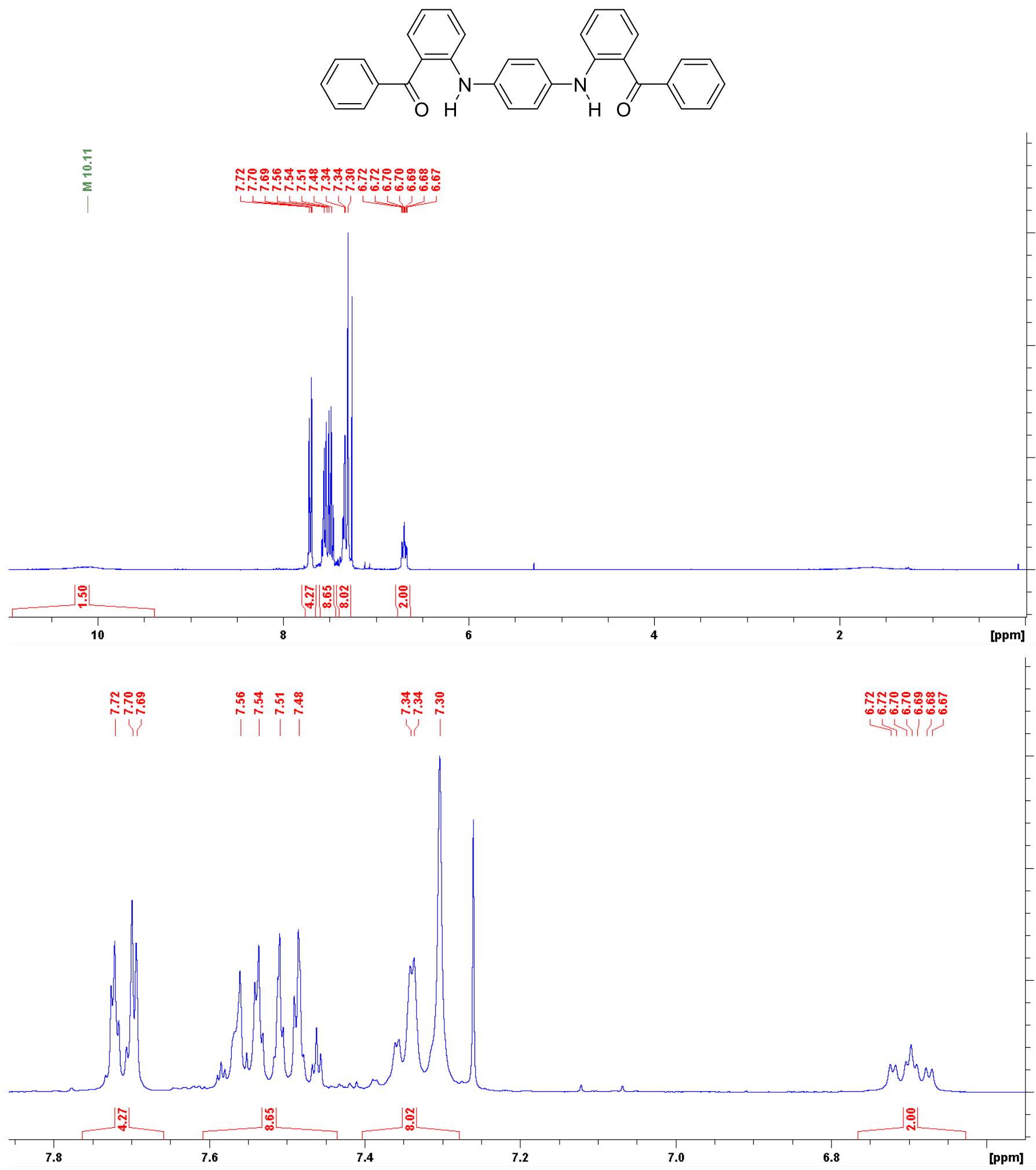

Figure S-F.31: ${ }^{1} \mathrm{H}$ NMR Spectrum $\left(300 \mathrm{MHz}, \mathrm{CDCl}_{3}\right)$. 


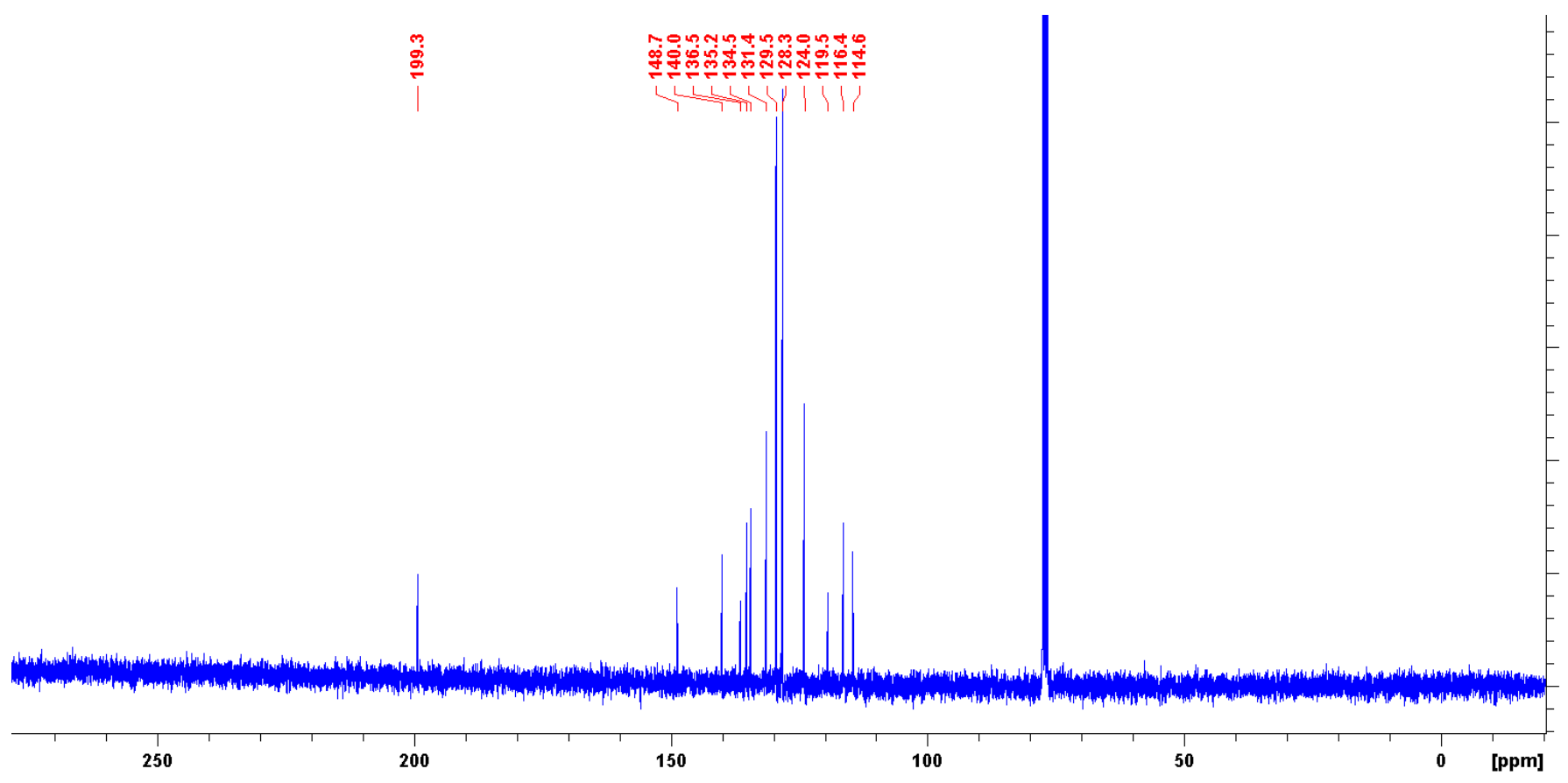

Figure S-F.32: ${ }^{13} \mathrm{C}$ NMR Spectrum $\left(75 \mathrm{MHz}, \mathrm{CDCl}_{3}\right)$. 
(1) Li, P. H.; Yu, L. Z.; Zhang, X. Y.; Shi, M. Cu(I)-Catalyzed Coupling and Cycloisomerization of Diazo Compounds with Terminal Yne-Alkylidenecyclopropanes: Synthesis of Functionalized Cyclopenta[ b]Naphthalene Derivatives. Org. Lett. 2018, 20 (15), 4516-4520. https://doi.org/10.1021/acs.orglett.8b01812.

(2) Connelly, N. G.; Geiger, W. E. Chemical Redox Agents for Organometallic Chemistry. Chem. Rev. 1996, 96 (2), 877910. https://doi.org/10.1021/cr940053x.

(3) Cardona, C. M.; Li, W.; Kaifer, A. E.; Stockdale, D.; Bazan, G. C. Electrochemical Considerations for Determining Absolute Frontier Orbital Energy Levels of Conjugated Polymers for Solar Cell Applications. Adv. Mater. 2011, 23 (20), 2367-2371. https://doi.org/10.1002/adma.201004554.

(4) Li, Q.; Wudl, F.; Thilgen, C.; Whetten, R. L.; Diederich, F. Unusual Electrochemical Properties of the Higher Fullerene, Chiral C76. J. Am. Chem. Soc. 1992, 114 (10), 3994-3996. https://doi.org/10.1021/ja00036a068.

(5) Zang, L.; Che, Y.; Moore, J. S. One-Dimensional Self-Assembly of Planar $\pi$-Conjugated Molecules: Adaptable Building Blocks for Organic Nanodevices. Acc. Chem. Res. 2008, 41 (12), 1596-1608. https://doi.org/10.1021/ar800030w.

(6) Schmidt-Mende, L.; Fechtenkötter, A.; Müllen, K.; Moons, E.; Friend, R. H.; MacKenzie, J. D. Self-Organized Discotic Liquid Crystals for High-Efficiency Organic Photovoltaics. Science (80-. ). 2001, 293 (5532), 1119-1122. https://doi.org/10.1126/science.293.5532.1119.

(7) Qian, H.; Negri, F.; Wang, C.; Wang, Z. Fully Conjugated Tri(Perylene Bisimides): An Approach to the Construction of n-Type Graphene Nanoribbons. J. Am. Chem. Soc. 2008, 130 (52), 17970-17976. https://doi.org/10.1021/ja807803j.

(8) Horowitz, G. Evidence for N-Type Conduction in a Perylene Tetracarboxylic Diimide Derivative. Adv. Mater. 1996, 8 (3), 242-245. https://doi.org/10.1002/adma.19960080312.

(9) Valeev, E. F.; Coropceanu, V.; Da Silva Filho, D. A.; Salman, S.; Brédas, J. L. Effect of Electronic Polarization on ChargeTransport Parameters in Molecular Organic Semiconductors. J. Am. Chem. Soc. 2006, 128 (30), 9882-9886. https://doi.org/10.1021/ja061827h.

(10) Gali, S. M.; Matta, M.; Lessard, B. H.; Castet, F.; Muccioli, L. Ambipolarity and Dimensionality of Charge Transport in Crystalline Group 14 Phthalocyanines: A Computational Study. J. Phys. Chem. C 2018, 122 (5), $2554-2563$. https://doi.org/10.1021/acs.jpcc.7b11588.

(11) D’Avino, G.; Olivier, Y.; Muccioli, L.; Beljonne, D. Do Charges Delocalize over Multiple Molecules in Fullerene Derivatives? J. Mater. Chem. C 2016, 4 (17), 3747-3756. https://doi.org/10.1039/c5tc03283k.

(12) Liu, T.; Troisi, A. What Makes Fullerene Acceptors Special as Electron Acceptors in Organic Solar Cells and How to Replace Them. Adv. Mater. 2013, 25 (7), 1038-1041. https://doi.org/10.1002/adma.201203486.

(13) Tomasi, J.; Mennucci, B.; Cammi, R. Quantum Mechanical Continuum Solvation Models. Chem. Rev. 2005, 105 (8), 2999-3093. https://doi.org/10.1021/cr9904009.

(14) Neese, F. The ORCA Program System. Wiley Interdiscip. Rev. Comput. Mol. Sci. 2012, 2 (1), 73-78. https://doi.org/10.1002/wcms.81.

(15) Frisch, M. J.; Trucks, G. W.; Schlegel, H. B.; Scuseria, G. E.; Robb, M. A.; Cheeseman, J. R.; Scalmani, G.; Barone, V.; Petersson, G. A.; Nakatsuji, H.; Li, X.; Caricato, M.; Marenich, A. V; Bloino, J.; Janesko, B. G.; Gomperts, R.; Mennucci, B.; Hratchian, H. P.; Ortiz, J. V; Izmaylov, A. F.; Sonnenberg, J. L.; Williams-Young, D.; Ding, F.; Lipparini, F.; Egidi, F.; Goings, J.; Peng, B.; Petrone, A.; Henderson, T.; Ranasinghe, D.; Zakrzewski, V. G.; Gao, J.; Rega, N.; Zheng, G.; Liang, W.; Hada, M.; Ehara, M.; Toyota, K.; Fukuda, R.; Hasegawa, J.; Ishida, M.; Nakajima, T.; Honda, Y.; Kitao, O.; Nakai, H.; Vreven, T.; Throssell, K.; Montgomery Jr., J. A.; Peralta, J. E.; Ogliaro, F.; Bearpark, M. J.; Heyd, J. J.; Brothers, E. N.; Kudin, K. N.; Staroverov, V. N.; Keith, T. A.; Kobayashi, R.; Normand, J.; Raghavachari, K.; Rendell, A. P.; Burant, J. C.; Iyengar, S. S.; Tomasi, J.; Cossi, M.; Millam, J. M.; Klene, M.; Adamo, C.; Cammi, R.; Ochterski, J. W.; Martin, R. L.; Morokuma, K.; Farkas, O.; Foresman, J. B.; Fox, D. J. Gaussian 16 Revision A.03. Gaussian Inc. Wallingford CT 2016. 